\author{
UNIVERSIDADE DE SÃO PAULO \\ ESCOLA DE ENGENHARIA DE SÃO CARLOS \\ DEPARTAMENTO DE GEOTECNIA
}

REGIANE VELOZO

\title{
Caracterização geológico-geotécnica do lixão desativado de São Carlos-SP, com auxílio da geofísica
}


REGI ANE VELOZO

\title{
Caracterização geológico-geotécnica do lixão desativado de São Carlos-SP, com auxílio da geofísica
}

\author{
Dissertação apresentada a Escola de \\ Engenharia de São Carlos, da Universidade de \\ São Paulo para obtenção do título de Mestre \\ em Geotecnia.
}

Área de concentração: Geotecnia Ambiental Orientador: Prof. Dr. Osni J osé Pejon

São Paulo 2006 


\section{FOLHA DE APROVAÇÃO}

Regiane Velozo

Dissertação apresentada a Escola de Engenharia de São Carlos, da Universidade de São Paulo para obtenção do título de Mestre em Geotecnia.

Área de concentração: Geotecnia Ambiental

Aprovado em:

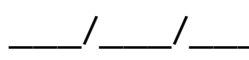

Banca Examinadora:

Prof. Dr.

Instituição:

Assinatura:

Prof. Dr.

Instituição:

Assinatura:

Prof. Dr.

Instituição:

Assinatura: 
Ao Fabrizzio, à minha mãe e aos meus irmãos Ricardo e Rozane 


\section{AGRADECIMENTOS}

À DEUS pela minha existência e por sua constante companhia;

À minha mãe e irmãos pelo amor, incentivo e apoio;

Ao Prof. Dr. Osni José Pejon, pela orientação, colaborando com críticas e sugestões para melhoria e andamento desse trabalho;

Ao Prof. Dr. Lázaro Valentim Zuquette pelas contribuições e sugestões ao trabalho;

Ao Departamento de Geotecnia, da Escola de Engenharia de São Carlos - USP, por toda infra- estrutura oferecida;

Ao Departamento de Astronomia e Geofísica (IAG), da Universidade de São Paulo, pela disponibilização do equipamento para realizar os ensaios geofísicos, em especial ao Prof. Dr. Vagner Roberto Elis, por ter acompanhado os ensaios e pela prontidão e disponibilidade em auxiliar no tratamento dos dados geofísicos;

À Coordenação de Aperfeiçoamento Pessoal de Nível Superior - Capes, pela concessão da bolsa de pesquisa;

À da Prefeitura Municipal de São Carlos, em especial ao Paulo Mancini, pelas informações concedidas;

Aos proprietários da Fazenda Santa Madalena, Álvaro e Lucia, por disponibilizar a área para pesquisa;

Aos técnicos Seu Antônio, Décio, Dito, Zé Luis e Oscar, pelo auxílio nos ensaios de laboratório e nas saídas à campo, e ao Ademar pelo auxilio na coleta de amostras;

Aos funcionários Maristela, Neiva e Álvaro, sempre dispostos a ajudar na parte administrativa e Herivelto na parte de informática;

Ao Zé Caparica, pela amizade e disposição em ajudar com os dados geofísicos;

Aos amigos engenheiros feitos durante esta caminhada, Ovídio, Silvia, J efersson, Cris, Thelma e Rafael, pela amizade, incentivo e auxílio nas disciplinas da engenharia;

À Nívea e Marcos, pelas sugestões e auxilio nos programas "novos", e pela tão importante amizade;

À Sylvia e Talles, grandes amigos, que tornaram os momentos difíceis mais fáceis;

Ao Fabrizzio, pelo amor, apoio, companheirismo e amizade, sempre;

Enfim, à todos aqueles que contribuíram para o desenvolvimento desse trabalho ou fizeram parte da minha vida neste período. 
Toda a nossa ciência, comparada com a realidade é primitiva e infantil - e, no entanto é a coisa mais preciosa que temos.

Albert Einstein (1879-1955) 


\section{RESUMO}

VELOZO, R. Caracterização geológico-geotécnica do lixão desativado de São Carlos-SP, com auxílio da geofísica. 2006. 177f. Dissertação (Mestrado) - Escola de Engenharia de São Carlos, Universidade de São Paulo, São Carlos, 2006.

Infelizmente os municípios brasileiros, em sua grande maioria, dispõem seus resíduos sólidos domiciliares sem nenhum controle, o que promove graves conseqüências, como contaminação do ar, do solo, das águas superficiais e subterrâneas. Este trabalho visou caracterizar geológica e geotecnicamente, com base em estudos geofísicos, o lixão desativado de São Carlos - SP, bem como analisar a evolução da contaminação já identificada por alguns autores anteriormente. Os resíduos foram dispostos inadequadamente nesta área por aproximadamente 17 anos, sobre os solos arenosos permeáveis da Formação Botucatu. Esta atividade cessou definitivamente em 1996, o que não finalizou o processo de contaminação, ainda atuante. Para investigação da evolução da pluma de contaminação realizaram-se caminhamentos elétricos (eletrorresistividade e polarização induzida), ensaios de infiltração e outros para caracterização dos materiais inconsolidados, associando estes dados aos já existentes. Os resultados mostram que a aplicação dessas técnicas permitiu caracterizar a situação de contaminação atual da área, mostrando que existe a propagação de uma pluma de contaminação com direção NW, e que verticalmente também pode estar ocorrendo contaminação. Essa contaminação no sentido vertical pode ser acentuada pela existência de uma descontinuidade sob o corpo do lixo, pela alta permeabilidade dos materiais arenosos da região, pela ausência de barreiras menos permeáveis e pela variação sazonal do nível d’água.

Palavras-chave: Resíduos sólidos urbanos; Resistividade elétrica; Ensaios de Infiltração, São Carlos. 


\begin{abstract}
VELOZO, R. Geological-Geotechnical characterization of the uncontrolled sanitary landfill of São Carlos-SP. 2006. 177f. Dissertation (MS) - Escola de Engenharia de São Carlos, Universidade de São Paulo, São Carlos, 2006.

Unfortunately the Brazilian cities, in its majority, discharge its domestic solid wastes without any control, which produces grave consequences such as contamination of the air, earth, and both superficial and the groundwater. This work carried out a geological-geotechnical characterization and geophysical studies of the uncontrolled sanitary landfill of São Carlos - SP, and also the analysis of the evolution of the contamination previously identified by other authors in the area. The residues were disposed inadequately in this area for approximately 17 years, in an area constituted by porous soils overlapping sandstones of Botucatu Formation. This practice ceased completely in 1996, but the contamination process didn't stop up to now. For investigation of the development of the plume of contamination several procedures were used: geophysical surveys (eletroresistivity and induced polarization), infiltration characterization testes of the unconsolidated materials and analysis of the results already existing. The results show that these techniques were enabled to characterizing the current situation of contamination of the area, showing that there is a propagation of a plume of contamination with direction NW, and that there also may be contamination occurring vertically. This contamination on the vertical direction may be allowed by the existence of a discontinuity under the sanitary landfill, high permeability of the sandy materials in the area, by the lack of less permeable layers and by the seasonal variation of the groundwater level.
\end{abstract}

Keywords: Solid domestic waste; Electrical resistivity, Induced polarization, Evatuation of Infiltration, São Carlos 


\section{LISTA DE FIGURAS}

Figura 01 - Representação esquemática de uma sondagem elétrica vertical....

Figura 02 - Representação esquemática de um caminhamento elétrico

Figura 03 - Exemplo de condutivímetro e modo de operação (CETESB, 2001).

Figura 04 - Exemplo de condutivímetro e modo de operação (CETESB, 2001).

Figura 05 - Princípio de operação do método eletromagnético indutivo (Yokoyama, 2003).. 26

Figura 06 - Equipamento para operação do radar de penetração (CETESB, 2001).... 28

Figura 07 - Exemplo de modo de operação do radar de penetração (CETESB, 2001). 28

Figura 08 - Localização da área de estudo (modificado de Gonçalves, 1986; Muro, 2000 e Prefeitura Municipal de São Carlos, 2005).

Figura 09 - Localização da área de estudo em imagem de satélite (Imagem Landsat 7 Miranda e Coutinho, 2001).

Figura 10 - Figura 10: Localização da área de estudo na província de Cuestas Basálticas, segundo Almeida, 1964.

Figura 11 - Vegetação na região do município de São Carlos, com indicação da área de estudo (modificado de SMA/SP, 2004).

Figura 12 - Solos presentes na região do município de São Carlos, com indicação da área de estudo (modificado de Secretaria Municipal de Desenvolvimento Sustentável, Ciência e Tecnologia - baseado no levantamento pedológico semidetalhado de estado de São Paulo apud Prefeitura Municipal de São Carlos, 2005).

Figura 13 - Divisão de bacias hidrográficas na região da área de estudo (baseado em Prefeitura Municipal de São Carlos, 2005).

Figura 14 - Foto da situação atual, com presença de resíduos, no córrego a jusante do 42 corpo do lixo.

Figura 15 - Localização do Aqüífero Guarani (CETESB, 2004).

Figura 16 - Mapa Geológico da região da área de estudo (modificado de Muro, 2000)..... 46

Figura 17 - Arenito da Formação Botucatu presente na área de estudo. ... 48 
Figura 18 - Vista atual da área de estudo, a linha azul indica a antiga cava de resíduos..... 51

Figura 19 - Mapa com localização dos poços, linhas de caminhamento elétrico e contorno da cava de depósito dos resíduos. Topografia baseada nos mapas IGC folhas SF-23-Y-A-I-1-NE-(C, D, E e F) de escala 1:10.000 e contribuições de Álvares, 2000 .

Figura 20 - Equipamento Iris Syscal R2 utilizado no ensaio de resistividade e cargabilidade.

Figura 21 - Representação esquemática do caminhamento elétrico executado.

Figura 22 - Localização dos pontos onde foram realizados os ensaios de infiltração. 60

Figura 23 - Montagem do ensaio de infiltração IAD in situ. 61

Figura 24 - Gráfico dos ensaios R,S e T, relacionando as três umidades, caracterizandoa frente de molhamento.

Figura 25 - Localização dos pontos onde foram coletadas amostras para os ensaios de caracterização de materiais inconsolidados.

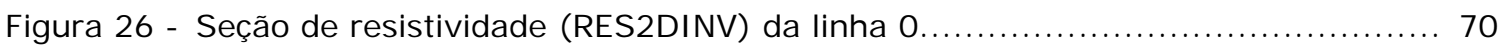

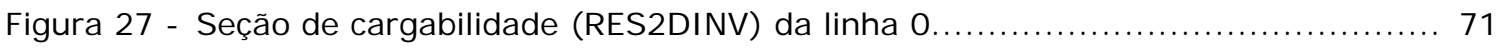

Figura 28 - Seção de resistividade (RES2DINV) da linha 1, nível d'água medido e dados da composição dos poços (Freitas, 1995 e Álvares 2000).....

Figura 29 - Seção de cargabilidade (RES2DINV) da linha 1, nível d'água medido e dados da composição dos poços (Freitas, 1995 e Álvares 2000).

Figura 30 - Figura 30: Seção de resistividade (RES2DINV) da linha 2, nível d'água medido e dados da composição dos poços (Freitas, 1995 e Álvares 2000).

Figura 31 - Seção de cargabilidade (RES2DINV) da linha 2, nível d'água medido e dados da composição dos poços (Freitas, 1995 e Álvares 2000).

Figura 32 - Seção de resistividade (RES2DINV) da linha 3, nível d'água medido e dados da composição dos poços (Freitas, 1995 e Álvares 2000).

Figura 33 - Seção de cargabilidade (RES2DINV) da linha 3, nível d'água medido e dados da composição dos poços (Freitas, 1995 e Álvares 2000).

Figura 34 - Seção de resistividade (RES2DINV) da linha 4, nível d'água medido e dados da composição dos poços (Freitas, 1995 e Álvares 2000). 
Figura 35 - Seção de cargabilidade (RES2DINV) da linha 4, nível d'água medido e dados da composição dos poços (Freitas, 1995 e Álvares 2000).

Figura 36 - Seção de resistividade (RES2DINV) da linha 5, nível d'água medido e dados da composição dos poços (Freitas, 1995 e Álvares 2000).

Figura 37 - Seção de cargabilidade (RES2DINV) da linha 5, nível d'água medido e dados da composição dos poços (Freitas, 1995 e Álvares 2000).

Figura 38 - Geologia conforme Muro (2000), com a localização da área de estudo em relação a falha por ele observada.

Figura 39 - Seções de resistividade de 2005 dispostas espacialmente com o contorno da cava de resíduos.

Figura 40 - Seções de cargabilidade 2005 dispostas espacialmente com o contorno da cava de resíduos.

Figura 41 - Modelo digital do terreno com sobreposição da foto aérea (1:25.000) da área de estudo em 1962, com indicação do contorno da cava de resíduos que seria posteriormente instalada.

Figura 42 - Modelo digital do terreno com sobreposição da foto aérea (1:25.000) da área de estudo em 1971, com indicação do contorno da cava de resíduos que seria posteriormente instalada.

Figura 43 - Modelo digital do terreno com sobreposição da foto aérea (1:30.000) da área de estudo em 2000, com indicação do contorno da cava de resíduos.

Figura 44 - Localização da área de estudo, com indicação da descontinuidade em imagem de satélite (Imagem Landsat 7 - Miranda, 2001)....

Figura 45 - Localização do perfil ABC, que corta o corpo do lixo em toda sua extensão...... 85

Figura 46 - Perfil ABC, que corta o corpo do lixo em toda sua extensão

Figura 47 - Seções de resistividade de 1995 dispostas espacialmente com o contorno da cava de resíduos....

Figura 48 - Mapas de resistividade aparente das profundidades de 10, 20 e 30 metros..... 88 


\section{LISTA DE TABELAS}

Tabela 01 - Métodos geoelétricos e os parâmetros físicos correspondentes analisados (Braga, 1999)

Tabela 02 - Comparativo de aplicações dos métodos geoelétricos (adaptado de CETESB, 2001 e Braga, 1999).

Tabela 03 - Dados dos Ensaios de Infiltração.

Tabela 04 - Dados obtidos com os ensaio de íncices físicos realizados....

Tabela 05 - Dados obtidos com os ensaio de granulometria conjunta (frações granulométricas segundo ABNT - NBR6502/95) ............................. 67

Tabela 06 - Dados obtidos com os ensaio de adsorção de azul de metileno...................68 


\section{LISTA DE SIGLAS E ABREVIATURAS}

ABNT - Associação Brasileira de Normas Técnicas

ANA - Agência Nacional de Água

APA - Área de Proteção Ambiental

ASTM - American Society for Testing and Materials

CETESB - Companhia de Tecnologia de Saneamento Ambiental

CNRH - Conselho Nacional de Recursos Hídricos

CTAS - Câmara Técnica de Águas Subterrâneas

DNPM - Departamento Nacional de Produção Mineral

EMBRAPA - Empresa Brasileira de Pesquisa Agropecuária

GPR - Radar de Penetração

IAD - Infiltrômetro de Anel Duplo

IBGE - Instituto Brasileiro de Geografia e Estatística

IP - Polarização Induzida

IPT - Instituto de Pesquisas Tecnológicas do Estado de São Paulo

MMA - Ministério do Meio Ambiente

NBR - Norma Brasileira Registrada

SEV - Sondagem Elétrica Vertical

SMA - Secretaria do Meio Ambiente

SP - Potencial Espontâneo

UTM - Universal Transverse Mercator 


\section{LISTA DE SÍMBOLOS}

A - Área transversal do anel

A-B - Eletrodos de emissão de corrente

Acb - Índice de atividade da fração argilosa

CTC - Capacidade de troca catiônica

e - Índice de vazios

$\mathrm{H}$ - Profundidade de água no anel quando ensaiado a regime constante

K - Condutividade hidráulica

M-N - Eletrodos de recepção de corrente

n - porosidade

Q - Volume de água infiltrada no solo

$\mathrm{R}$ - distância do centro de A-B até o centro de M-N

SE - Superfície específica

$\mathrm{Sr}$ - Grau de saturação

$\mathrm{t}$ - Tempo entre medidas

$\mathrm{Vb}$ - Valor de azul de metileno adsorvido

w - Umidade média natural

$\mathrm{X}$ - Espaçamento entre os dipolos A-B e M-N

Z - Profundidade da frente de saturação

$\rho$ - Massa específica do solo

$\rho_{d}$ - Massa específica seca do solo

$\rho_{s}-$ Massa específica dos sólidos 


\section{SUMÁRIO}

1. I NTRODUÇÃO........................................................................ 1

2. REVI SÃO BI BLI OGRÁFI CA.................................................... 3

2.1. Disposição de resíduos sólidos........................................ 3

2.1.1. Os resíduos......................................................... 3

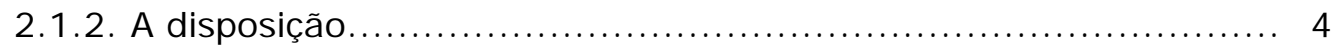

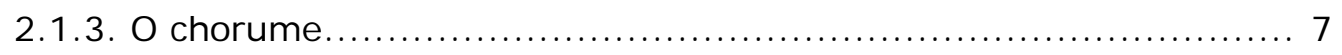

2.2. Águas Subterrâneas.............................................. 8

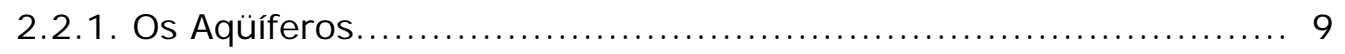

2.2.2. Contaminação e Poluição....................................... 10

2.2.3. Remedição.......................................................... 11

2.2.4. Movimento da água subterrânea e transporte de poluentes........ 12

2.2.5. Legislação e gestão.................................................. 14

2.3. Investigações geológico-geotécnicas............................... 17

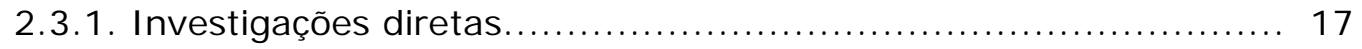

2.3.2. Investigações indiretas......................................... 20

\section{LOCALIZAÇÃo e CARACTERísticas gerais dA ÁREA de}

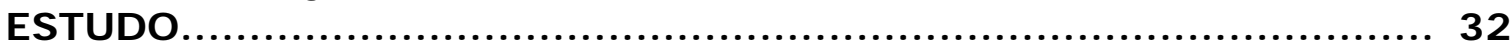

3.1. Localização....................................................... 32

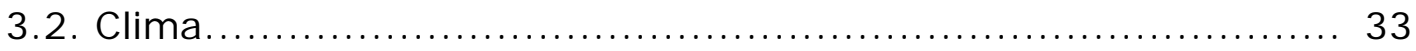

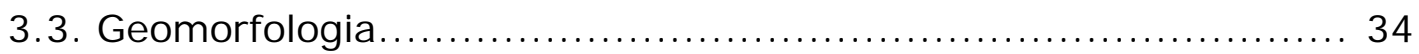

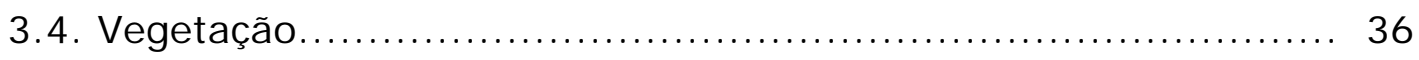

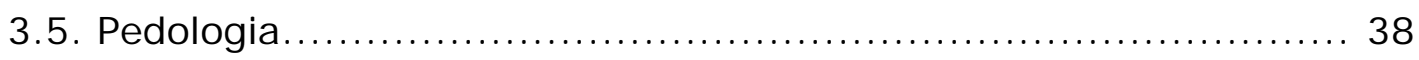

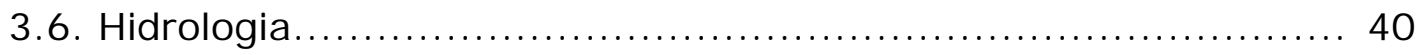

3.6.1. Águas Superficiais.................................................. 40

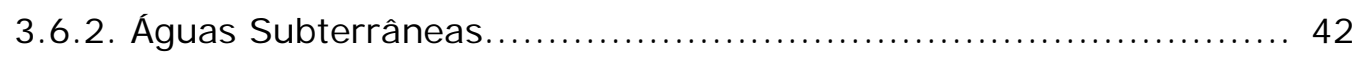

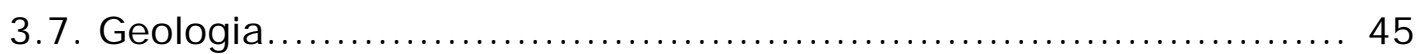

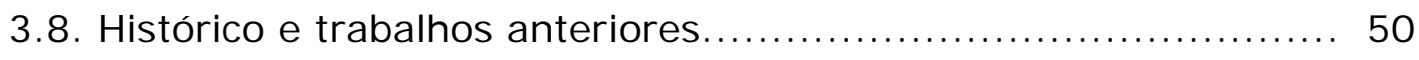

4. PROCEDI MENTOS E RESULTADOS......................................... 54

4.1. Ensaios geofísicos.................................................... 54 
4.1.1. Locação das linhas.................................................. 54

4.1.2. Execução do ensaio............................................... 55

4.1.3. Tratamento dos dados....................................... 58

4.1.4. Resultados da Geofísica....................................... 59

4.2. Ensaios de infiltração...................................... 59

4.2.1. Locação dos pontos ensaiados................................. 60

4.2.2. Execução...................................................... 60

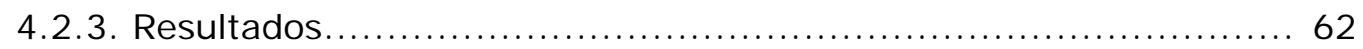

4.3. Ensaios de caracterização dos materiais inconsolidados............ 65

4.3.1. Locação dos pontos ensaiados.................................... 65

4.3.2. Resultados............................................................ 66

5. ANÁLI SE E DI SCUSSÃO DOS RESULTADOS..................................69

5.1. Seções Geofísicas...................................................... 69

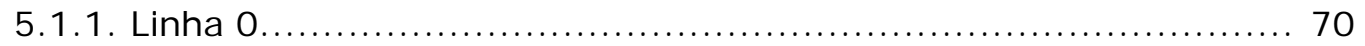

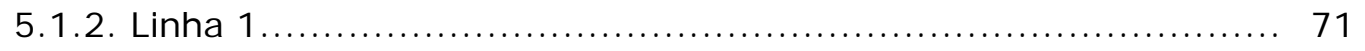

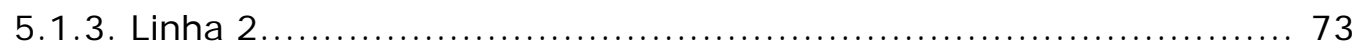

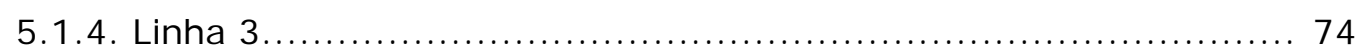

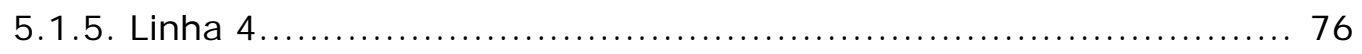

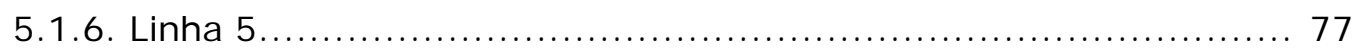

5.2. Análise da evolução da contaminação no período de 1995 a 2005...... 78

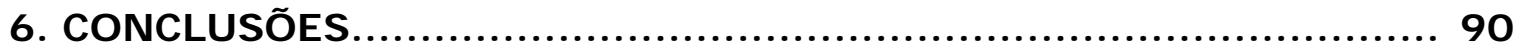

REFERÊNCI AS BI BLI OGRÁFI CAS................................................... 92

ANEXO I - LOCALIZAÇÃO DOS POÇOS ........................................ 107

ANEXO II - PERFIS GEOFÍSICOS........................................... 109

ANEXO III - PLANILHAS DE CAMPO / ENSAIOS DE INFILTRAÇÃO............. 125

ANEXO IV - PLANI LHAS DE CÁLCULO E CURVAS DE INFILTRAÇÃO/

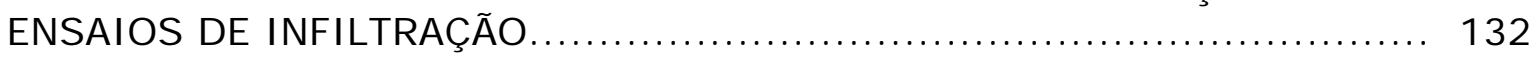

ANEXO V - CURVAS GRANULOMÉTRICAS.................................... 139 


\section{Introdução}

O crescente avanço industrial e tecnológico da civilização concentrada em grandes centros urbanos gera a necessidade cada vez maior de produção de energia, além de uma quantidade de resíduos superior a que o ambiente pode suportar.

O depósito de lixo doméstico, industrial e de serviços de saúde, sem um prévio estudo geológico e hidrológico é um fenômeno nocivo a sociedade, uma vez que promove a degradação do meio ambiente.

Segundo IPT (1995) o depósito de resíduos sólidos pode ser feito de três formas: em lixões (simples despejo dos resíduos no solo), em aterros controlados (deposição dos resíduos no solo com um certo grau de controle, compactação e cobertura) ou em aterros sanitários (acomodação dos resíduos, associada a obras de engenharia, de maneira isolada e segura, no menor espaço possível).

Infelizmente a forma de disposição de resíduos sólidos predominante no Brasil ainda é em lixões, freqüentemente feita em depressões naturais ou em voçorocas, acentuando a possibilidade de contaminação e poluição das águas subterrâneas.

Em geral, essas águas subterrâneas apresentam características físicas perfeitamente compatíveis com os padrões de potabilidade, sendo uma fonte rica para o abastecimento hídrico das cidades, diante do aumento populacional, deterioração das reservas superficiais e menor custo de produção.

Para manter a potabilidade das águas subterrâneas os órgãos ambientais têm dado especial atenção as áreas de disposição de resíduos. Dentre os métodos utilizados nos estudos de deteç̧ão e monitoramento de plumas de contaminação nesses locais de depósito destacam-se os métodos geofísicos, em especial os geoelétricos.

Segundo Elis (1998) a aplicação de métodos geofísicos elétricos podem fornecer, se adequadamente escolhidos e dimensionados, informações importantes 
com respeito a estrutura dos depósitos e definição do sentido de fluxo subterrâneo, assim como outras relações entre os resíduos e as características geológicas, geotécnicas e hidrogeológicas do local de estudo.

A área de estudo foi definida por apresentar esse sério problema ambiental, o de contaminação devido a presença do lixão desativado do município de São Carlos, no estado de São Paulo, localizado na Fazenda Santa Madalena. Neste local foram depositados resíduos, inadequadamente em uma voçoroca, por aproximadamente 17 anos.

Como essa disposição de resíduos não foi feita da maneira ideal, não possui sistema de impermeabilização ou de coleta dos fluidos produzidos pela degradação do lixo, proporcionando a contaminação das águas superficiais e, pela percolação desses fluidos, das águas subterrâneas.

Essa contaminação já foi constatada anteriormente por outros autores, como Ellert et al. (1990), Bossolan (1993), Menezes (1995), Freitas (1996), Gadotti (1997) e Álvares (2000). Apesar de diversos estudos terem sido desenvolvidos na área anteriormente, existe uma carência de informações da situação atual da contaminação.

Isso reflete um problema para a cidade de São Carlos, uma vez que, o seu abastecimente de água é feito em parte por águas subterrâneas, e em parte por água superficial coletada na Bacia Hidrográfica do Ribeirão do Feijão, na qual insere-se o Córrego São José, que encontra-se a jusante do lixão.

O objetivo principal desse trabalho foi a caracterização geológico-geotécnica da área, de forma a estabelecer correlações entre os resíduos aterrados e a dinâmica hidrogeológica atuante, buscando delimitar uma possível pluma de contaminação, com base em dados produzidos em ensaios geofísicos, de infiltração e de caracterização dos materiais inconsolidados. Buscou-se também analisar os dados obtidos em estudos anteriores e compará-los com os atuais, estabelecendo a evolução e a situação atual da contaminação.

Neste estudo adotaram-se dois métodos elétricos de investigação geofísica, o de eletrorresistividade e o de polarização induzida, devido a estes métodos terem se mostrados adequados em estudos anteriores para determinações de relações entre os componentes de aterro e do meio físico, além do sentido do fluxo subterrâneo.

Espera-se que os estudos e dados gerados nesta pesquisa possam servir para um melhor conhecimento da situação atual da área, bem como na elaboração e aplicação de medidas mitigadoras do problema de contaminação existente. 


\section{Revisão Bibliográfica}

Quando se fala em preservação do meio ambiente, nosso pensamento se volta para florestas, mares e biodiversidade, mas com o aumento da quantidade de resíduos sólidos urbanos gerados, atentou-se para o fato que a disposição do lixo também pode gerar um problema ambiental de grande escala, afetando o solo, a água e a atmosfera.

Para tanto, segundo Aguiar (2001) são extremamente importantes pesquisas realizadas para que os parâmetros e os comportamentos mecânico e químico dos resíduos sejam conhecidos e compreendidos, bem como que desenvolvam novos mecanismos de investigação.

\subsection{Disposição de resíduos sólidos}

\subsubsection{Os resíduos}

A Associação Brasileira de Normas Técnicas (ABNT), por meio da NBR (Norma Brasileira Registrada) 10.004 (1987), define resíduos sólidos como "resíduos nos estados sólido e semi-sólido, que resultam de atividades da comunidade de origem: industrial, doméstica, hospitalar, comercial, agrícola, de serviços e de varrição.". Consideram-se também como resíduos sólidos os lodos provenientes dos sistemas de tratamento de água, aqueles gerados em equipamentos e em instalações de controle de poluição, bem como determinados líquidos cujas particularidades tornem inviável seu lançamento na rede pública de esgotos ou corpos de água, ou exijam para isso soluções técnicas e economicamente inviáveis em face à melhor tecnologia disponível. 
A classificação dos resíduos quanto aos seus riscos potenciais ao meio ambiente e à saúde pública também é abordada na NBR-10004, para que estes resíduos possam ter manuseio e destinação adequados. São adotados:

- Resíduos Classe I - Perigosos: Apresentam periculosidade ou uma das seguintes características: inflamabilidade, corrosividade, reatividade, toxicidade e patogenicidade, como por exemplo, baterias e produtos químicos.

- Resíduos Classe II - Não Inertes: São os resíduos que não se enquadram como resíduos classe I e classe III, e podem ter as seguintes propriedades: combustibilidade, biodegradabilidade ou solubilidade em água, como por exemplo, matéria orgânica e papel.

- Resíduos Classe III - Inertes: Não têm constituinte algum solubilizado em concentração superior ao padrão de potabilidade de águas, como por exemplo, rochas, tijolos, vidros e certos plásticos e borrachas que não são decompostos prontamente.

Embora o tratamento e disposição final deve ser diferenciado para cada classe de resíduos, isso nem sempre ocorre, sendo que usualmente são descartados resíduos potencialmente perigosos juntamente com os resíduos domésticos. Os resíduos perigosos mais encontrados são materiais para pintura (tintas, solventes, pigmentos, vernizes), materiais para jardinagem (pesticidas, inseticidas, repelentes, herbicidas), materiais automotivos (óleos lubrificantes, fluidos de freios e de transmissão, baterias), entre outros intens como pilhas, frascos de aerossóis e lâmpadas fluorescentes.

\subsubsection{A disposição}

Infelizmente, segundo Schalch et al. (2002), os municípios brasileiros, em sua grande maioria, dispõem seus resíduos sólidos domiciliares sem nenhum controle, uma prática que promove graves conseqüências, como contaminação do ar, do solo, das águas superficiais e subterrâneas, criação de focos de organismos patogênicos, vetores de transmissão de doenças, com sérios impactos na saúde pública.

Prima-se que a disposição final desses resíduos gere o menor impacto no meio, que seja de simples operação e de baixo custo. Atualmente um dos poucos métodos adequados, pelo menos em parte, a essas características é a disposição final em aterros sanitários, que, segundo Leite (1997), é difundido em quase todo o mundo.

Alguns processos como a compostagem ou a incineração podem se tornar viáveis economicamente em grandes centros urbanos, mas deve-se ressaltar que tais processos não descartam a existência de aterros sanitários como disposição final, pois 
o tratamento nunca constitui um sistema de destinação completo ou definitivo, gerando sempre um remanescente inaproveitável.

$\checkmark \quad$ Lixão e aterro sanitário

Deve-se deixar claro que existe uma diferença conceitual, operacional e ambiental entre lixão e aterro sanitário.

O lixão representa o que há de mais primitivo em termos de disposição final de resíduos, onde todo o lixo coletado é transportado para um local afastado do centro urbano e descarregado diretamente no solo, sem tratamento algum, impactando diretamente todo o meio, manifestando vários efeitos negativos, como por exemplo, a proliferação de ratos e moscas, a exalação do mau cheiro, a contaminação dos lençóis freáticos, o surgimento e transmissão de doenças, alem do transtorno do visual e olfativo.

O aterro sanitário é uma disposição baseada em técnicas sanitárias como impermeabilização do solo, compactação e cobertura diária das células de lixo, coleta e tratamento de gases, coleta e tratamento dos líquidos residuais, entre outras, que são responsáveis em evitar os aspectos negativos da deposição final do lixo (IPT, 1995).

Entretanto, apesar das vantagens, este método enfrenta limitações por causa do crescimento das cidades, associado ao aumento da quantidade de lixo produzido (Lopes, 2003).

O sistema de aterro sanitário precisa ser associado à coleta seletiva de lixo e à reciclagem, o que permitirá que sua vida útil seja bastante prolongada, além do aspecto altamente positivo de se implantar uma educação ambiental com resultado promissores na comunidade, desenvolvendo coletivamente uma consciência ecológica, cujo resultado é sempre uma maior participação da população na defesa e preservação do meio ambiente (Schalch, et al.2002).

Entretanto, dados do IBGE (2000) sobre a Pesquisa Nacional de Saneamento Básico, mostram que das 228.413 toneladas de resíduos produzidos por dia no Brasil, $37 \%$ são destinados a aterros controlados, 36\% para aterros sanitários, $21,2 \%$ para lixões, 2,9\% para compostagem, 1,0\% para triagem de reciclagem, 0,6\% para locais não fixos, $0,5 \%$ para icineração, $0,1 \%$ para áreas alagadiças e $0,7 \%$ para outros destinos.

Segundo, dados do IBGE (2002), também sobre a Pesquisa Nacional de Saneamento Básico, mostraram que apenas 13,4\% dos municípios brasileiros dispõem seus resíduos em aterros sanitários, $18,3 \%$ em aterros controlados, e o restante dos 
municípios $(68,3 \%)$ dispõe seus resíduos em locais impróprios, como é o caso dos lixões.

Segundo Elis (1998), as fontes mais comuns de contaminação no Brasil são as áreas utilizadas para deposição de resíduos, devido ao descaso e a opção por alternativas de baixo custo para dispor esses resíduos, como lixões a céu aberto. A locação dessas áreas é de responsabilidade dos órgãos governamentais, que na maioria das vezes não respeitam as limitações do ambiente escolhido, nem seguem regras básicas de manejo de aterros sanitários.

Segundo Menezes, et al. (1995), os antigos lixões e aterros dificilmente se enquadram na legislação, pois, em geral, foram instalados em locais inadequados, sem estudo prévio, mesmo que sejam cumpridas as exigências da cobertura, irão continuar a emitir poluentes.

Essas áreas já existentes, ativas ou não, tem sido pouco abordadas, causando uma carência de propostas para esse setor. Um agravante para essas áreas é que comumente ocorria o deposito não só dos resíduos domiciliares, mais também os provenientes dos serviços e saúde e industriais (Hassuda et al., 1998).

\section{$\checkmark$ Seleção de áreas}

As áreas destinadas para implantação de aterros têm uma vida útil limitada e novas áreas são cada vez mais difíceis de serem encontradas próximas aos centros urbanos. Aperfeiçoam-se os critérios e requisitos analisados nas aprovações dos Estudos de Impacto Ambiental pelos órgãos de controle do meio ambiente; além do fato de que os gastos com a sua operação se elevam, com o seu distanciamento.

Segundo Santos e Koide (1998), na seleção de área e execução do aterro sanitário, os recursos hídricos naturais devem ser preservados na medida do possível. Assim, locais com córregos ou nascentes devem ser evitados.

Zuquette e Gandolfi (2004), propuseram uma lista de atributos que devem ser considerados nos procedimentos de seleção e verificação de locais para implantação de aterros sanitários:

- Substrato rochoso: atributos como litologia e profundidade;

- Materias inconsolidados: descontinuidade, classificação textural, variação vertical, mineralogia, matacões, $\mathrm{pH} / \Delta \mathrm{pH}$, salinidade, CTC, camada compressível, material colapsível, índice de erodibilidade, fator de retardamento e características de compactação;

- Água: profundidade da zona saturada, direção do fluxo saturado, fluxo superficial, condutividade hidráulica, áreas de recarga, distância da nascente e drenabilidade; 
- Processos (feições): erosão, movimentos de massa gravitacionais, subsidências, feições cársticas e zonas de inundação;

- Relevo: formas de relevo, distância do limite entre bacias hidrográficas, zonas úmidas e declividade;

- Características climáticas: evapotranspiração, direção do vendo e pluviosidade.

$\checkmark$ Cobertura do Aterro

Deve ser dada atenção especial à cobertura de um aterro sanitário, que apresenta como função principal impedir a transferência de contaminantes para a biosfera e prevenir a infiltração das águas de precipitações para dentro da massa de lixo, limitando, assim, o risco de contaminação dos solos e das águas subterrâneas (IPT, 1995).

Segundo Saarela (1993) a cobertura de aterro sanitário tem as seguintes funções:

- Prevenção ou minimização de percolação;

- Melhoria estética;

- Supressão de vetores;

- Contenção de gases;

- Supressão do risco de incêndio;

- Prevenção de carreamento de lixo;

- Valorização do local do aterro.

- E deve apresentar os seguintes atributos:

- Resistência à erosão pela água;

- Resistência à erosão pelo vento;

- Estabilidade contra recalques, fissuras e escorregamentos;

- Resistência a baixas temperaturas;

- Resistência a perfurações feitas por animais e plantas.

\subsubsection{O chorume}

Segundo Tressoldi e Consoni (1994), a disposição de resíduos é um efetivo agente contaminante do solo e subsolo, pois com a decomposição da matéria orgânica presente no lixo é gerado o percolado (chorume), um líquido escuro, ácido e de alta DBO (Demanda Bioquímica de Oxigênio).

Quanto maior a demanda de oxigênio necessária para a decomposição biológica dos compostos orgânicos presentes no chorume, maior sua capacidade poluidora e, quanto mais ácido esse percolado, maior seu poder em carrear metais presentes na 
massa de lixo. Seu volume e capacidade de lixiviação vão depender da quantidade de água e precipitação atmosférica que atinja os resíduos, da quantidade e qualidade da matéria orgânica e do tipo de solo (Tressoldi e Consoni, 1994).

A contaminação das águas subterrâneas ocorre através da percolação de águas pluviais e outros líquidos gerados pela própria degradação dos resíduos, que por infiltração no solo sob o aterro atingem o nível d'água (Bocanegra, et al.1998).

Esse percolado contém normalmente elevadas concentrações de amônia, sólidos totais dissolvidos, carbono orgânico, cloreto, ferro, além concentrações menores de um grande número de outros contaminantes inorgânicos e orgânicos. Esses contaminantes não são unicamente gerados a partir dos resíduos sólidos, mas também provenientes de resíduos líquidos industriais dispostos inadequadamente na maioria dos aterros (Mirecki e Parks, 1994).

Para tanto, o IPT (1995) sugere que seja feito um controle ambiental dessas áreas de disposição, com monitoramento da qualidade e quantidade do chorume produzido e carreado para as áreas vizinhas.

Os contaminantes, quando dispostos na superfície, atravessam os diferentes horizontes de solo não saturado e a zona capilar, atingindo a zona saturada, essa migração é controlada por diferentes processos físicos, químicos e biológicos (Foster, 1988).

Segundo Haitjema (1991), os aterros tradicionais são projetados e monitorados de forma imprópria para a proteção da água subterrânea, em virtude do conhecimento incompleto sobre o tempo de residência do chorume nas camadas compactas, a integridade das geomembranas, a heterogeneidade dos aqüíferos e as trajetórias dos contaminantes.

As medidas para o controle e prevenção da poluição devem ser estudadas, e devem ser tomadas por todo tipo de organização, seja ela pública ou privada. As cidades ao realizarem planejamento e elaboração de Planos Diretores devem considerar essa questão, assim como as indústrias, desde o momento de sua implantação devem consideradas como estratégia para a garantia de um ambiente sustentável (Lopes, 2003).

\section{2. Águas Subterrâneas}

Segundo a definição da Associação Brasileira de Normas Técnicas (ABNT), na NBR-9896 de 1993, "água subterrânea é a água que ocupa a zona saturada do subsolo ou num sentido mais amplo, toda a água situada abaixo da superfície do solo, na litosfera". 
As águas subterrâneas representam $28,8 \%$ da água doce líquida da Terra, que segundo Hirata (2000) já representaria seu valor, já que desempenha papel fundamental no abastecimento público e privado em todo o mundo. Estima-se que mais de 1,5 bilhões de pessoas em núcleos urbanos e uma grande parcela da população rural tenham suas necessidades supridas pelo manancial subterrâneo, com tendências mundiais ao crescimento contínuo desse uso.

\subsubsection{Os Aqüíferos}

Cabe ressaltar que as águas subterrâneas podem ser encontradas em aqüíferos, que segundo Hirata (2004), são unidades saturadas constituídas por rochas porosas e permeáveis, ou seja, aqüíferos são formações geológicas capazes de transportar, e não somente armazenar, água.

Para saber a qualidade, a quantidade e a durabilidade da água de um aqüífero, devem ser realizados estudos hidrológicos, hidrogeológicos, bacteriológicos, físicoquímico, assim como os dados relativos à pluviosidade (Vangente e Gaspar, 2004).

Quanto mais homogêneos forem o tamanho e a distribuição dos poros e maior a interconexão entre esses poros, melhor será a capacidade do aqüífero em transmitir água. A espessura do aqüífero garante a quantidade de água e o seu grau de confinamento, além de propiciar uma maior ou menor proteção contra a poluição (CETESB, 2004).

Segundo Rebouças et al. (2002) os aqüíferos podem desempenhar diversas funções, como:

- Função de produção, que é a mais comum, responsável pelo abastecimento de uma parcela considerável da população da Terra;

- Função ambiental e de filtro, pois a maioria dos aqüíferos atua como verdadeiros "filtros bio-físico-geoquímicos", de forma a conduzir à atenuação natural de poluentes. Lembrando que dependendo da natureza da porosidade, comportamento hidráulico do aqüífero, uma vez poluído, pode ser praticamente impossível uma restauração;

- Função estratégica e de regularização, a função estratégica aborda a função de atender a gerações presentes e futuras, sempre de forma sustentável e a função de regularização aborda a permissão de maximizar ofertas em períodos de escassez de água superficial, sendo utilizado, por exemplo, como meio para a reserva através de recarga artificial etc.;

- Função transporte e energética, pouco utilizadas no Brasil, um exemplo da função de transporte é quando se faz um poço tubular raso, em um aqüífero aluvial, às margens de curso d'água, de modo que se está 
bombeando, na verdade, água do rio, a qual flui através do meio granular, utilizando, dessa forma o aqüífero com a função transporte e filtro. A função energética advém de aqüíferos com águas termais, e pode ser utilizada, por exemplo, para a geração de energia elétrica.

\subsubsection{Contaminação e Poluição}

Segundo Branco (1991) deve ser feita uma distinção entre os termos contaminação e poluição, visto que contaminação refere-se à simples transmissão, pela água, de elementos, compostos ou microorganismos que possam prejudicar a saúde do homem ou de animais que a bebem. Já a poluição se caracteriza muito mais por seus efeitos ecológicos, que produzem transformações do meio ambiente.

A CETESB (2001) definiu área contaminada como:

Área onde há comprovadamente poluição causada por quaisquer substâncias ou resíduos que nela tenham sido depositados, acumulados, armazenados, enterrados ou infiltrados, e que determina impactos negativos sobre os bens a proteger.

As áreas contaminadas podem gerar diversos problemas, entre eles Sanchez (1998) ressalta quatro principais:

- Existência de risco a segurança das pessoas e das propriedades;

- Riscos a saúde pública e dos ecossistemas;

- Restrições ao desenvolvimento urbano;

- Redução do valor imobiliário das propriedades.

Segundo Hirata (2000) as águas subterrâneas apresentam, em sua grande maioria, excelente qualidade física e química, permitindo sua utilização para o consumo humano sem tratamento. Embora a importância desse recurso na qualidade de vida da população seja inquestionável, está sujeito à degradação devido às atividades do desenvolvimento urbano (Melo et al., 1996).

Segundo CETESB (2004) as principais fontes de poluição para as águas subterrâneas estão relacionadas com o uso do solo para disposição de resíduos (aterros, lixões, cemitérios, ferro velhos) e infiltração de efluentes das atividades química (instalação de industrias, hospitais, farmácias), mecânica, metalúrgica e curtume, além de fontes consideradas difusas como a agricultura, notadamente a adubação pesada e o uso inadequado de pesticidas.

Apesar de serem uma reserva estratégica de água potável, os aqüíferos estão cada vez mais expostos à poluição, a contaminação das águas subterrâneas, ao contrário da contaminação das águas superficiais, não são logo detectadas devido à lenta circulação de suas águas, capacidade de adsorção do solo e explotação 
difusamente distribuída, o que dificulta e onera as soluções para o problema (Kyrillos e Cabral, 1996).

Segundo Cesarini et al. (2004) a alteração na qualidade da água subterrânea deve ser motivo de preocupação para a sociedade, já que a poluição do solo, que é um bem privado, é a principal causa desta alteração, que sendo uma reserva natural de água potável, não deve correr riscos de contaminação.

No que diz respeito à qualidade de água para consumo humano, a Portaria do Ministério da Saúde estabeleceu padrões de potabilidade mais restritivos e contemplando um maior número de parâmetros. Estabeleceu ainda os procedimentos e as responsabilidades relativas ao controle de qualidade para o consumo humano.

\subsubsection{Remedição}

Mesmo quando a água subterrânea não é utilizada diretamente (poços), deve ser feito um controle de contaminação, pois a maioria dos aqüíferos aflora, recarregando os recursos hídricos superficiais, podendo contaminá-los.

Tendo isolado o avanço da pluma, trabalhos no controle da fonte e outras medidas de remediação podem ser executadas em ritmo usual (Fetter, 1993), tais como bioventing (injeção de ar através da zona não saturada e franja capilar); air sparging (injeção de ar através da zona saturada para remediação das águas subterrâneas pela volatilização e biodegradação dos contaminates), atenuação natural monitorada (os microorganismos existentes em subsuperfície degradam os contaminantes com o tempo), entre outros.

Segundo Tressoldi e Consoni (1994), os trabalhos para a remediação de áreas contaminadas por resíduos devem necessariamente, passar pela etapa inicial de diagnóstico, quando são coletadas informações sobre o meio ambiente atingido e sobre as características da contaminação. É efetuada a avaliação de impactos com base em indicadores ou fatores ambientais e são conduzidas investigações e monitoramento detalhados para melhor caracterizar e quantificar os impactos e para efetuar o estudo das alternativas de remediação.

Ao final da fase de diagnóstico, deve-se ter completo conhecimento do fluxo de contaminantes no meio analisado. Devem ser considerados todos os parâmetros geológicos e hidrogeológicos, obtidos das investigações e monitoramento, de modo que se possa definir o projeto de descontaminação, implementar as medidas mitigadoras e prosseguir com o monitoramento.

Segundo CETESB, (2001) a aplicabilidade de um método de remediação depende de vários fatores, como características do meio contaminado e do contaminante, do objetivo da remediação, da localização da área, do tempo e dos 
recursos disponíveis. São utilizadas, basicamente três abordagens no planejamento de um projeto de remediação:

- Mudança do uso;

- Remoção ou destruição dos contaminantes;

- Redução da concentração ou contenção dos contaminantes.

Os sistemas de contenção para isolar contaminantes do meio ambiente incluem remoção do solo para tratamento, sistemas de bombeamento com tratamento convencional e injeção de água tratada, sistemas de bombeamento e tratamento in situ, por meio de injeção de agentes químicos e biológicos, drenos e barreiras hidráulicas, barreiras impermeabilizantes, barreiras reativas in situ, barreiras geológicas, tapetes e selos (argila compacta ou geomembrana) com dispositivos associados para a drenagem e coleta de percolado e biodegradação natural (Tressoldi e Consoni, 1994).

\subsubsection{Movimento da água subterrânea e transporte de poluentes}

A interação solo-contaminante é muito complexa, uma vez que, muitos fenômenos físicos, químicos e biológicos podem ocorrer simultaneamente. São inúmeros os fenômenos que controlam o transporte de contaminantes em meios porosos, onde o contaminante considerado é a massa de alguma substância tóxica dissolvida (poluente), movendo-se com algum fluido (água) nos vazios do meio poroso (solo) seja ele saturado ou não (Nobre, 1987).

Nas áreas utilizadas para disposição de resíduos urbanos e industriais, a contaminação das águas subterrâneas ocorre através da percolação de águas pluviais e outros líquidos gerados pela própria degradação dos resíduos, que por infiltração no solo sob o aterro atingem o nível d'água. No caso dos resíduos urbanos, o líquido derivado desse processo de percolação através dos resíduos é o chorume.

Quando os resíduos são dispostos de maneira inadequada pode ocorrer infiltração de líquidos contendo substâncias contaminantes até atingir as águas subterrâneas, comprometendo sua qualidade (Elis, 2002).

Segundo Tressoldi e Consoni (1994), o fluxo da água na zona não saturada (poros preenchidos por água e ar) depende da força da gravidade e da forma dos poros, sendo vertical para baixo. Na zona saturada (poros preenchidos por água) o fluxo depende do gradiente hidráulico e os contaminantes podem espalhar-se por grandes áreas, cobrindo longas distâncias, após períodos de tempo variável. Caracterizam-se assim as plumas de contaminação com concentrações variáveis, no espaço e no tempo, dependendo das condições hidrogeológicas locais. 
Segundo Fetter (1993) o movimento de poluentes não depende apenas do fluxo do fluido no qual essas substâncias estão dissolvidas, mas sim de mecanismos aos quais estas substâncias são submetidas, os principais mecanismos de transporte e retenção de contaminantes em meios porosos saturados são:

\section{$\checkmark$ Advecção}

Advecção é o mecanismo de transporte de massa causado pelo movimento da água. Durante a evolução da maioria das plumas de poluição, a advecção é o mecanismo de transporte mais importante.

Segundo Shackelford (1988), na advecção, os contaminantes (solutos) presentes na água se movem na direção das linhas de fluxo com uma velocidade que, em princípio, é igual à velocidade média linear da água e sem alterar sua concentração na solução.

\section{$\checkmark$ Dispersão Hidrodinâmica}

Segundo Freeze e Cherry (1979) a dispersão hidrodinamica é o fenômeno que permite o espalhamento tridimensional do contaminante, proporcionando diluição do contaminante pelo caminho do escoamento.

O processo de difusão molecular não pode ser separado da dispersão mecânica no fluxo de água pelo solo, portanto esses dois processos são combinados para definir a dispersão hidrodinâmica.

(1) Difusão molecular: esse transporte ocorre devido ao gradiente de concentração existente em um fluido, ou seja, o soluto dissolvido em água desloca-se de uma área de maior concentração para uma área de menor concentração, visando equalizar a concentração em toda a massa de fluido.

Segundo Elbachá (1989), este fenômeno ocorre independente da velocidade do fluido, mas é acentuado pela turbulência resultante dos mecanismos de mistura mecânica.

Segundo Mitchell (1991), em um solo, especialmente de granulometria fina, a difusão é consideravelmente menor do que em uma solução livre. Isso se deve a tortuosidade das trajetórias de fluxo, pequeno volume de fluido para o fluxo e retenção de íons e moléculas nas superfícies das partículas.

(2) Dispersão mecânica: a mistura mecânica é decorrente da dispersão em canais individuais, do desenvolvimento de velocidades médias diferentes em canais diferentes, devido à variação das dimensões dos poros ao longo das linhas de fluxo, e do desvio da trajetória das partículas em decorrência da tortuosidade, reentrâncias e interligações entre os canais (Bear, 1972). 
A dispersão que ocorre na direção do fluxo é chamada dispersão longitudinal e a que ocorre na direção perpendicular ao fluxo é chamada dispersão transversal.

\section{$\checkmark$ Sorção}

A sorção engloba os processos que demonstram a capacidade do solo em reter substâncias. A adsorção é a adesão de moléculas ou íons à superfície de partículas no solo promovendo uma diminuição da concentração da fase aquosa e retardando o transporte de contaminante, já a desorção é a liberação da fase sólida. A habilidade do solo em reter substâncias é limitada, se a fonte de contaminação tiver alimentação contínua, a taxa de retenção tende a diminuir com o tempo, podendo chegar a se anular (Yong et al., 1992).

A transferência da substância para a fase sólida durante o fluxo provoca redução da frente de contaminação em relação à velocidade do fluido, resultando no fenômeno de retardamento da frente de contaminação (Nobre, 1987).

\section{$\checkmark$ Decaimento}

O processo de decaimento é de importância relativamente menor e é de difícil quantificação. Os principais processos são os de ácido-base, solução-precipitação, oxidação-redução, complexação e processos microbiológicos, que tem como conseqüência o retardamento na velocidade de avanço do contaminante (Nobre, 1987).

\subsubsection{Legislação e gestão}

No Brasil, no contexto de recursos hídricos, a maior ênfase ainda é dada aos recursos superficiais, embora, segundo o Ministério do Meio Ambiente - MMA, (2001) as águas subterrâneas apresentem grande importância, com um volume armazenado estimado em $112.000 \mathrm{~km}^{3}$, sendo que diversos aqüíferos se estendem por área subjacente a vários estados, chegando a alcançar países vizinhos, o que impõe uma articulação dos entes federados para a gestão deste recurso natural.

A água subterrânea vem assumindo importância relevante como fonte de abastecimento, mais da metade da água de abastecimento público no Brasil provém das reservas subterrâneas (ANA, 2004).

A legislação brasileira deve se adequar a essas novas condições de uso, que se encontram em crescimento, impulsionado, segundo Domingues e Oliveira (2004), pelo comprometimento progressivo da qualidade das águas superficiais, especialmente nos grandes centros populacionais, o que eleva cada vez mais o custo do tratamento dessas águas, além do baixo custo da água subterrânea. 
No Brasil, há uma série de leis federais que trazem em seu corpo artigos que tratam da água subterrânea, mas não há em vigor uma que trate exclusivamente da mesma.

No Código das Águas (1934) as águas subterrâneas eram consideradas bens imóveis, associados à propriedade da terra. Esta legislação inibia a monopolização da exploração e a poluição das águas subterrâneas e reconhecia sua estreita correlação com as águas superficiais.

Já a Constituição Federal de 1988, em vigência, previu a criação do Sistema Nacional de Gerenciamento dos Recursos Hídricos e alterou o Código das Águas, de forma que, no Brasil, a água é um bem público e seu disciplinamento de uso e sua proteção são regidos por legislações que delegam aos órgãos Federais e Estaduais atribuições especificas.

Com a Lei Federal $n^{\circ}$ 9.433, de 08/01/1997, regulamentada pelo Decreto $n^{\circ}$ 2.612 de 03.06.1998, foi instituída a Política Nacional de Recursos Hídricos, criando o Sistema Nacional de Gerenciamento de Recursos Hídricos. Esta Lei organizou o setor de planejamento e gestão dos recursos hídricos em âmbito nacional.

Quanto a sua dominialidade, a abordagem de águas subterrâneas na legislação federal brasileira, é de certa maneira dúbia, visto que, algumas vezes elas são tratadas como recurso hídrico e em outras como recurso mineral, o que implica diretamente na gestão, outorga, cobrança, fiscalização e direitos de uso dessas águas.

No artigo 26 da Constituição Federal Brasileira de 1988, a água subterrânea é tratada como um recurso hídrico, sendo sua dominialidade dos estados-membros. Já o artigo 20 permite tratá-la como recurso mineral, o que a remete ao Código de Águas Minerais e ao Código de Mineração, onde sua dominialidade é da união.

Para tanto se faz necessário definir o que são águas subterrâneas e quando elas são minerais, já que isso influencia diretamente na interpretação jurídica que deve ser dada.

Segundo Suguio (1998) água subterrânea pode ser definida como parte da água subsuperficial contida na zona de saturação, enquanto que águas minerais, conforme artigo $1^{0}$ do Código de Águas Minerais, instituído pelo Decreto-Lei no 7.841/45, "são aquelas provenientes de fontes naturais ou de fontes artificialmente captadas que possuam composição química ou propriedades físicas ou físico-químicas distintas das águas comuns..."

Se as águas forem enquadradas como minerais será necessária a autorização do Departamento Nacional de Produção Mineral (DNPM) para sondagens, além de alvarás de pesquisa e no caso de exploração será necessária a obtenção de uma concessão de lavra, emitida pelo DNPM, segundo as portarias 222/1997 e 231/1998, 
com base no Código de Minas (Decreto-Lei no 227/67) e no Código de Águas Minerais (Decreto-Lei no 7841/45).

Segundo Affonso e Monsores (2004), do ponto de vista jurídico, para a classificação das águas subterrâneas como recursos minerais é exigido, quando da captação dessas águas, o seu enquadramento aos dispositivos legais observados nos artigos 35 e 36 do Código de Águas Minerais, onde são definidas suas classificações químicas. Ao constatar-se que essas águas estão contaminadas, com necessidade de tratamento, fica descaracterizada sua qualificação como água mineral, passando a se enquadrar como água comum.

Portanto pode-se concluir que apenas em situações bem definidas é que as águas subterrâneas são consideradas como minerais, cabendo salientar que águas subterrâneas podem ter usos múltiplos, enquanto que as minerais têm usos específicos definidos por lei (engarrafamento, venda, balneoterapia e uso geotermal).

Segundo Acselrad et al. (2004) existe no meio técnico um entendimento de que há necessidade de legislação específica para as águas subterrâneas, apesar do reconhecimento do caráter de avanço e inovação da Lei de Recursos Hídricos.

Segundo Domingues e Oliveira (2004) foi um marco para a integração das águas subterrâneas e águas superficiais, no âmbito da Política Nacional de Recursos Hídricos, a elaboração, pela Câmara Técnica de Águas Subterrâneas - CTAS e a aprovação pelo Conselho Nacional de Recursos Hídricos - CNRH de três resoluções:

- Resolução nº 9 de 21/06/2000 que instituiu a Câmara Técnica Permanente de Águas Subterrâneas;

- Resolução n 15 de 11/01/2001 que estabelece as diretrizes para gestão integrada das águas considerando a interdependência entre as águas superficiais, subterrâneas e meteóricas;

- Resolução n 22 de 24/05/2002 que estabelece que os Planos de Recursos Hídricos Estaduais e dos Comitês de Bacia deverão considerar o monitoramento da qualidade e quantidade de águas subterrâneas, estudos hidrogeológicos e a inter-relação com as águas superficiais, visando a gestão integrada dos recursos hídricos.

Há ainda uma proposta de Emenda Constitucional que propõe a mudança da dominialidade dos corpos hídricos subterrâneos subjacentes a mais de uma unidade federada ou que ultrapassem a fronteira com outros países (caso do Aqüífero Guarani, compartilhado por quatro países da América do Sul) para a União, definição similar ao conceito de dominialidade para os corpos hídricos superficiais (Acselrad et al., 2004). 
Segundo o MMA (2001), a maioria dos estados brasileiros ainda carece de uma legislação e ação específica para essa importante fração dos recursos hídricos que são, constitucionalmente, de domínio dos estados.

Estados como São Paulo e Pernambuco contam com lei específica de águas subterrâneas, outros estados têm procurado integrar as águas subterrâneas à Política Estadual de Recursos Hídricos.

No estado de São Paulo o licenciamento ambiental de empreendimentos potencialmente poluidores é considerado uma ação preventiva contra a poluição na medida em que estabelece exigências específicas para que as fontes de poluição se instalem de forma ambientalmente segura.

A fiscalização é considerada uma forma de atuação corretiva, onde procura-se adequar os processos visando a minimização dos riscos de poluição. A elaboração de instruções e normas técnicas, resoluções e legislações sobre disposição de efluentes e resíduos sólidos é outra importante ferramenta para a prevenção da poluição dos solos e águas subterrâneas (CETESB, 2004).

Segundo Custódio (1994), a gestão de aqüíferos é o conjunto de guias, normas, leis, regulamentos e atuações destinadas a sustentar, conservar, proteger, restaurar e regenerar esses aqüíferos. Faz referência à quantidade e à qualidade da água captável do aqüífero, que se deve fazer de forma compatível com a demanda a servir, com outras demandas existentes, com o meio ambiente e com a ordenação e uso do território.

Se a gestão integrada dos recursos hídricos for adotada na sua forma ideal, deve evitar alguns problemas hoje existentes com relação a esses recursos, no caso de águas subterrâneas, pode evitar a explotação excessiva, a contaminação de aqüíferos, intrusões salinas, interferência nos cursos d'água, rebaixamento excessivo, diminuição de escoamento de base dos rios, subsidências e colapsos.

\subsection{Investigações geológico-geotécnicas}

\subsubsection{Investigações diretas}

Primeiramente devem ser feitas investigações para as avaliações sobre a variabilidade geológica da área, sobre as condições de fluxo da água subterrânea e sobre o potencial de contaminação das fontes de água e dos solos. 


\section{$\checkmark$ Sondagens e amostragem de solo}

As sondagens e amostragens de solo têm por objetivos principais a caracterização da estratigrafia, da hidrogeologia, dos solos, das estruturas, da geoquímica, da extensão da pluma, da petrografia e mineralogia, resistência, deformabilidade, capacidade de troca catiônica, quantidade de matéria orgânica etc.

Para a caracterização de um maciço de solo deve ser coletado um volume, o mais representativas possível, do material original ou área a ser caracterizada.

O objetivo da amostragem do solo é assegurar a obtenção de informações confiáveis, para tanto, segundo CETESB (2001), os seguintes fatores devem ser considerados na elaboração do plano de amostragem do solo:

- Distribuição dos pontos de amostragem;

- Número de pontos de amostragem;

- Profundidade de amostragem;

- Quantidade de amostra necessária;

- Amostras simples e compostas;

- Preparação de amostras de solo;

- Técnicas de amostragem;

Segundo CETESB (2001), em áreas suspeitas de contaminação ou contaminadas, a distribuição das substâncias contaminadoras deve ser investigada tanto no sentido horizontal (superfície do solo) quanto no vertical (perfil do solo). Entretanto, a profundidade de amostragem do solo variará de acordo com alguns fatores que influenciam a distribuição dos contaminantes nesse meio, tais como: natureza da contaminação (substância), tipo de solo e condições do local (uso atual e passado).

De maneira geral, a definição do número de pontos a serem amostrados dependerá do tamanho da área investigada; da qualidade das informações prévias disponíveis, das hipóteses de distribuição espacial da contaminação e do grau de confiança requerido.

\section{$\checkmark$ Poços de monitoramento}

Os poços de monitoramento têm como objetivos principais efetuar medições do nível d'água subterrânea (instalação de piezômetros), coletar amostras de água subterrânea para sua caracterização e efetuar ensaios hidrológicos para determinação de velocidade e direções de fluxo, condutividade hidráulica e dispersividade.

O sistema de monitoramento deve ser eficaz em identificar a influência de uma determinada fonte de poluição na qualidade da água subterrânea. As amostragens devem ser efetuadas num conjunto de poços distribuídos estrategicamente, nas 
proximidades da área de disposição do resíduo, de forma a oferecer subsídios para o diagnóstico da situação.

A localização estratégica e a construção racional dos poços de monitoramento, aliadas aos métodos eficientes de coleta, acondicionamento e análise de amostras, permitem dados precisos quanto a influência do método de disposição dos resíduos, na qualidade da água subterrânea (CETESB, 2001).

$\checkmark$ Ensaios de permeabilidade

Segundo Aguiar (2001), diversos ensaios para determinação do coeficiente de permeabilidade têm sido desenvolvidos e aperfeiçoados ao longo do tempo. Busca-se através disto uma maior representatividade nos resultados, a redução dos custos dos ensaios e o aperfeiçoamento dos aparelhos de medição em campo, tornando-os mais práticos e de fácil utilização.

Os ensaios mais utilizados para a determinação da condutividade hidráulica dos solos são:

- Ensaios em laboratório: de carga constante ou variável

Esses ensaios são realizados com amostras indeformadas, que são colocadas em um cilindro entre duas placas porosas.

No ensaio de carga constante a amostra é submetida a uma carga constante até que se atinja a saturação e que o fluxo de saída se torne constante. No ensaio de carga variável é utilizada a diferença entre as cargas em um determinado intervalo de tempo.

Segundo Vargas (1981) apud Aguiar (2001), o ensaio de carga constante é mais usado em solos arenosos, enquanto o ensaio de carga variável é mais usado em solos argilosos devido a grande diferença de permeabilidade dos dois solos e o tempo que seria necessário para um solo argiloso num ensaio de carga constante.

- Ensaios in situ: poços e furos

Nestes ensaios obtém-se a condutividade hidráulica saturada. Podem ser realizados tanto com carga constante quanto com carga variável e permitem trabalhar com infiltração ou bombeamento de água.

Para solos granulares os ensaios para obtenção da condutividade hidráulica não saturada têm duas fases, a fase transiente, enquanto o NA é rebaixado e a de regime estacionário, quando a vazão se torna constante. Para aqüífero confinado, pode-se usar o ensaio de bombeamento (Aguiar, 2001). 
- Ensaios in situ: Hvorslev

Segundo Aguiar (2001), no método de Hvorslev são usados piezômetros instalados até a profundidade ensaiada. Da mesma forma que o método anterior, este ensaio pode ser realizado através de adição ou remoção de água do piezômetro. A variação do nível d'água em determinado intervalo de tempo é registrada até que se atinja o estado de equilíbrio.

- Ensaios in situ: infiltrometro de duplo anel

Nesse ensaio é utilizado um infiltrômetro provido de dois cilindros metálicos de diferentes diâmetros, com uma das bordas biseladas para facilitar a penetração no solo.

Para a realização do ensaio, coloca-se água no cilindro interno e externo, de maneira a tornar o fluxo d'água unidimensional. São ser feitas leituras em tempos subseqüentes $(1,2,3,4,5,10,20,30,45,60,90$ e 120 minutos) até que o fluxo estabilize-se, de maneira constante.

O ensaio do Infiltômetro do Anel Duplo (IAD) é estabelecido segundo a norma ASTM-D 3385-88 (1988), e é importante por fornecer informações acerca do comportamento hidráulico dos materiais inconsolidados.

- Ensaios in situ: câmara de fluxo

Nesse ensaio utiliza-se um cilindro metálico de aço inox, com a base composta por um material de aço-carbono para dar maior resistência à cravação.

Essa câmara é cravada a $70 \mathrm{~cm}$ de profundidade, seguindo-se as mesmas rotinas do infiltrômetro de anel duplo (Fabian e Ottoni Filho, 1997 apud Aguiar 2001).

- Ensaios in situ: perfil instantâneo

São instalados instrumentos no solo para medição da carga de pressão e do conteúdo de água. Inicialmente este solo é submetido a uma taxa de infiltração até que se alcance um regime estacionário. Depois de alcançado, interrompe-se a recarga, sendo permitida a redistribuição da água dentro do solo. Este processo de redistribuição é acompanhado por medidas periódicas de umidade que são utilizadas no cálculo da condutividade hidráulica (Aguiar, 2001).

\subsubsection{Investigações indiretas}

Dentre os métodos de investigação indireta, os métodos geofísicos elétricos são os mais utilizados em estudos ambientais, principalmente para a detecção de contaminação de águas subsuperficiais (Elis, 1998). Os métodos geofísicos são 
técnicas de investigação das estruturas de subsuperfície através da aquisição e interpretação de dados instrumentais, caracterizando-se como métodos não invasivos ou não destrutivos.

Esses métodos permitem avaliar as condições geológicas locais através dos contrastes das propriedades físicas dos materiais de subsuperfície, com a vantagem da rápida avaliação de grandes áreas com custo relativamente menor, além da execução de perfis contínuos, possibilitando a identificação com maior precisão das variações laterais decorrentes das mudanças litológicas ou originadas pela presença da contaminação subterrânea (CETESB 2001).

Segundo Elis e Zuquette (1995), os métodos e técnicas geofísicas podem ser utilizados nas mais diversas vertentes do mapeamento geotécnico, como para obter informações básicas para fundações, escavabilidade, disposição de resíduos, estradas, poluição, obras enterradas, estabilidade de taludes, erodibilidade, irrigação e loteamento.

No diagnóstico ambiental de áreas contaminadas, os levantamentos geofísicos podem contribuir na identificação da contaminação subterrânea, além da definição das feições geológicas e hidrogeológicas dos locais investigados. A interpretação dos dados geofísicos pode contribuir para a obtenção de informações sobre a litologia, estratigrafia, profundidade do nível d'água, profundidade do embasamento, presença de falhas ou fraturas, existência de aqüíferos, caminhos preferenciais de propagação subterrânea e outras feições geológicas de interesse.

Segundo CETESB (2001), para a seleção de um método geofísico a ser empregado, o ideal é ter conhecimento da geologia local, das características físicoquímicas das águas subterrâneas e do contaminante, do tipo de material utilizado e da proximidade de edificações e instalações.

Dentre os aspectos mencionados, dois deles são preponderantes e decisivos na escolha do método geofísico a ser empregado, que são: o tipo de contaminação e o ambiente geológico onde está disposto o contaminante.

Os métodos geoelétricos subdividem-se em eletrorresistividade, polarização induzida (IP), potencial espontâneo (SP), eletromagnéticos e radar de penetração (GPR) e utilizam os parâmetros físicos expostos na Tabela 1 para a determinação de seções geoelétricas. 
Tabela 01: Métodos geoelétricos e os parâmetros físicos correspondentes analisados (Braga, 1999).

\begin{tabular}{|c|c|}
\hline METODOS GEOELÉTRI COS & PARÂMETROS Fí SI COS \\
\hline Eletrorressistividade & resistividade elétrica \\
\hline polarização induzida & variações de voltagem \\
\hline potencial espontâneo & potencial natural \\
\hline eletromagnético & condutividade \\
\hline radar de penetração & constante dielétrica/permissividade \\
\hline
\end{tabular}

Segundo Braga (1999), as superfícies de separação de uma seção geoelétrica nem sempre coincidem com os limites geológicos determinados pelos caracteres litológicos genéticos e geológicos em geral. Um pacote com geologia homogênea pode gerar seções subdivididas em camadas geoelétricas distintas, assim como pode ocorrer de várias camadas geológicas diferentes gerarem uma seção sem descontinuidades.

\section{$\checkmark$ Eletrorresistividade}

Dentre os métodos elétricos, o método da eletrorresistividade, por fazer o uso da condução direta de corrente, é provavelmente o mais simples para manipulação e também o mais simples para entendimento. Este método procura identificar a distribuição da resistividade no solo e utilizá-la como subsídio no estudo da subsuperfície. O método tem sido empregado em pesquisas de águas subterrâneas visando a monitoração de aqüíferos em terrenos sedimentares, na prospecção de minérios condutivos, em estudos arqueológicos, em estudos ambientais e de fontes geotermais, e na geologia de engenharia visando determinar a profundidade da rocha sã (Telford et al. 1990).

O método da eletrorresistividade consiste basicamente no uso de medidas da diferença de potencial elétrico entre dois pontos do terreno, associadas às distribuições de correntes elétricas contínuas ou de baixa freqüência, de origem artificial, visando determinar a resistividade elétrica dos materiais geológicos em subsuperfície (Santos, 2003).

Segundo Elis (1998), o método da eletrorresistividade consiste na introdução de uma corrente elétrica artificial através de dois eletrodos (A e B), com o objetivo de medir o potencial gerado em outros dois eletrodos ( $\mathrm{M}$ e $\mathrm{N}$ ) nas proximidades do fluxo de corrente, permitindo a determinação da resistividade real ou aparente em subsuperfície. 
Nas profundidades de interesse a resistividade da Terra é função principalmente da porosidade das rochas/estruturas e do conteúdo em água, ou seja, uma alta porosidade gera um alto grau de saturação em água, proporcionando baixa resistividade/alta condutividade.

Segundo Elis (1998) a resistividade dos solos e rochas que possuem condutividade eletrolítica é função principalmente de quatro fatores: composição mineralógica, porosidade, teor de água e quantidade e natureza dos sais dissolvidos. Nos estudos ambientais os fatores mais importantes são a quantidade de água contida e a salinidade dessa água, pois o aumento desses valores leva a uma diminuição de valores de resistividade.

Existem duas técnicas de aplicação do método de eletrorresistividade, o de sondagem elétrica vertical (SEV) e o de caminhamento elétrico, sendo que cada um permite uma gama de configurações de eletrodos, promovendo uma versatilidade muito boa do método.

\section{$\checkmark$ Sondagem elétrica vertical (SEV)}

A técnica de sondagem elétrica vertical é normalmente utilizada quando deseja-se informação pontual, consiste numa série de determinações de resistividade aparente, em um ponto fixo, a profundidades cada vez maiores, através da separação crescente entre os eletrodos A e B (Fernandes, 1984), como ilustrado na Figura 01.

Em investigações ambientais, a técnica da SEV desempenha papel importante na detecção e caracterização da poluição do subsolo e seus recursos hídricos (Lima e Porsani, 1994).

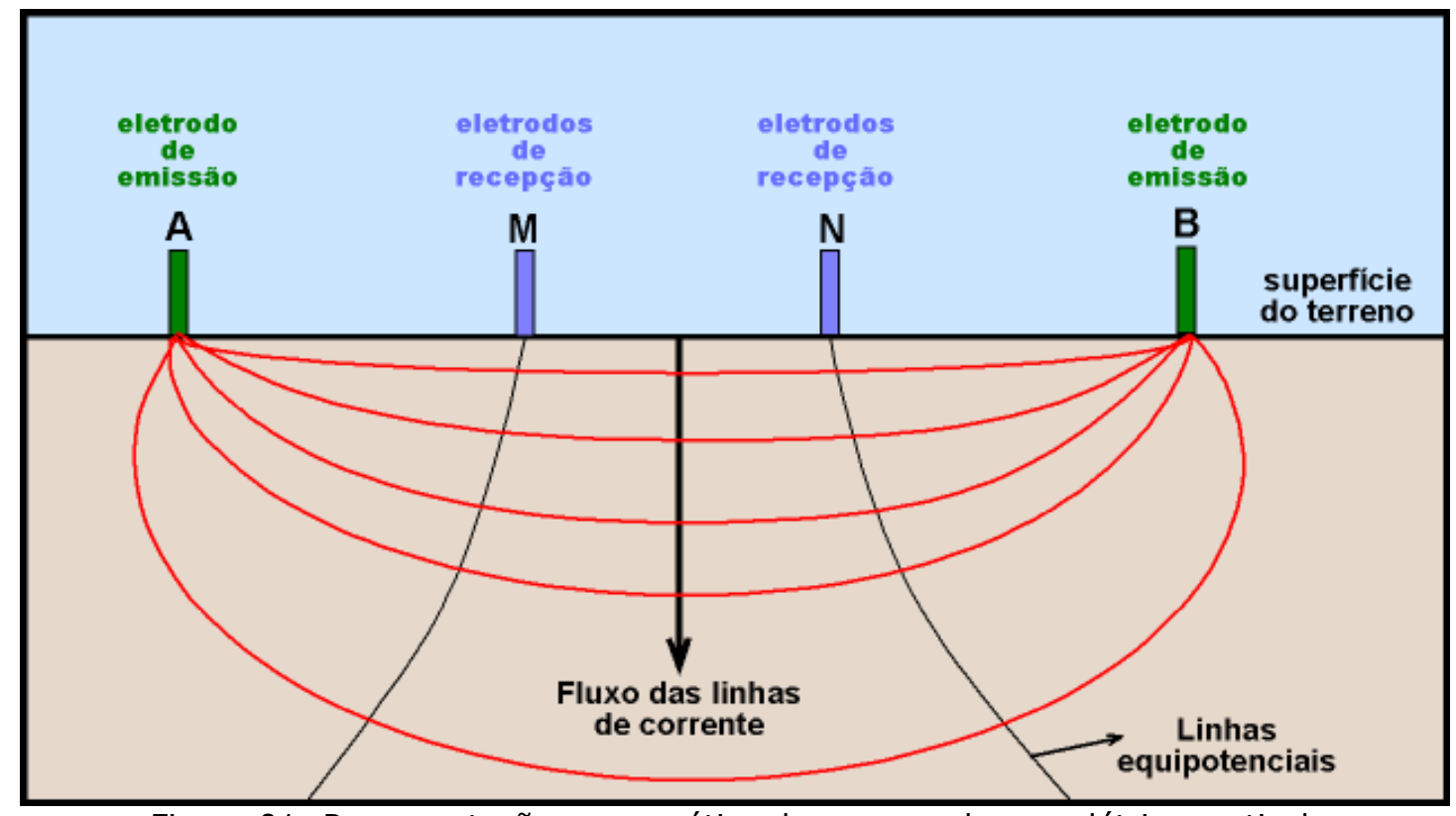

Figura 01: Representação esquemática de uma sondagem elétrica vertical. 
A aplicação de técnicas adequadas durante a fase de coleta de dados de SEV associada a métodos robustos de interpretação permite estimar parâmetros importantes na caracterização geológico-hidrológica de áreas de disposição de resíduos tais como a profundidade da rocha sã, a profundidade do nível estático e a direção do fluxo da água subterrânea (Cavalcante et al. 1996).

Os métodos geoelétricos são viabilizados para investigações hidrológicas pela quantidade e as propriedades físico-químicas da água intersticial, bem como a sua interação com a rocha hospedeira, que norteiam o comportamento da condução elétrica na rocha (Cavalcante et al. 1996).

\section{$\checkmark$ Caminhamento elétrico}

O método de caminhamento elétrico consiste em obter a variação lateral de resistividade a profundidades aproximadamente constantes. Fixa-se um espaçamento entre eletrodos e caminha-se ao longo de perfis, efetuando medidas de resistividade aparente (Elis, 1998), como indicado na Figura 02.

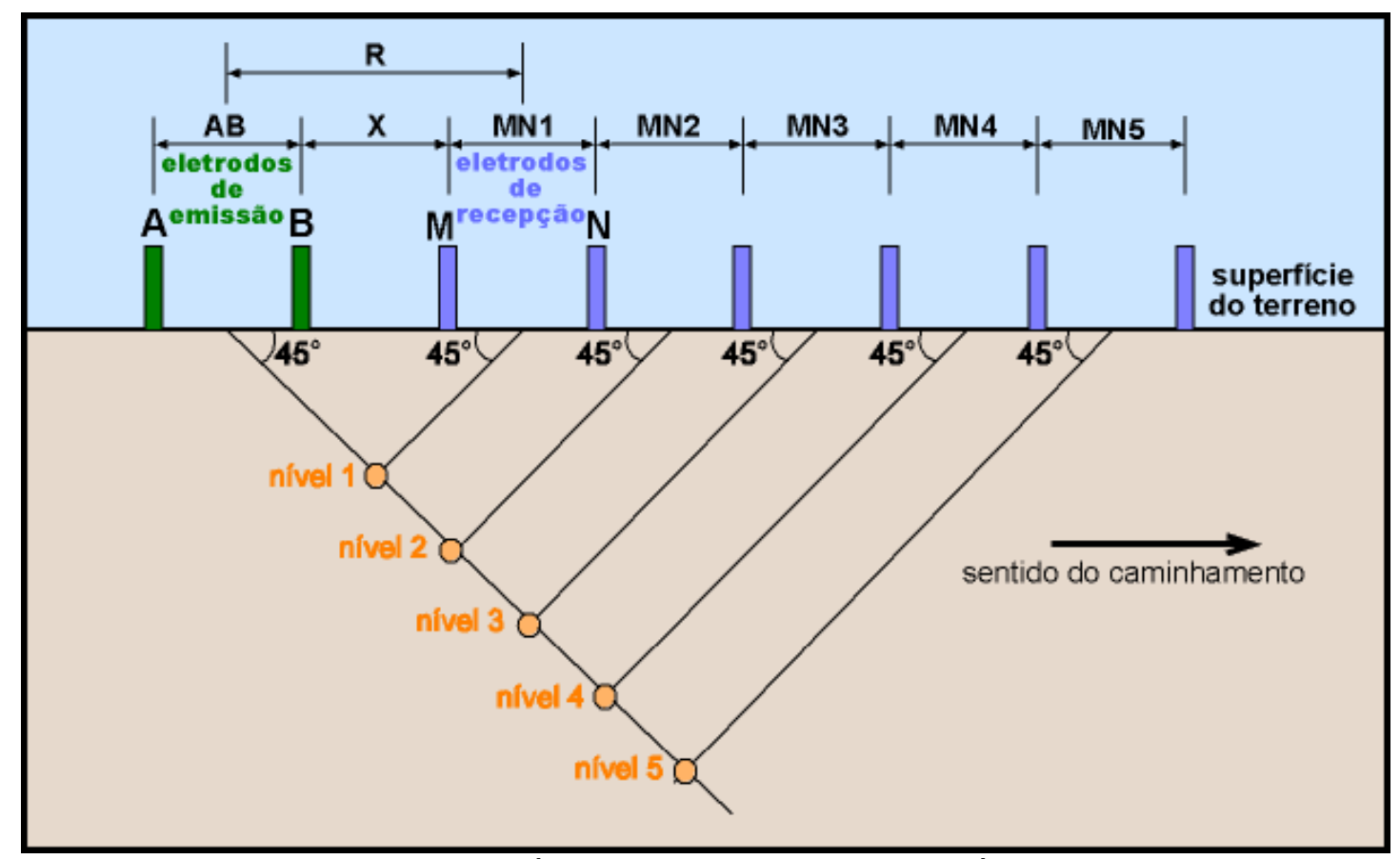

Figura 02: Representação esquemática de um caminhamento elétrico, arranjo dipolo-dipolo.

As múltiplas possibilidades de disposição geométrica de eletrodos correspondem a uma grande variedade de arranjos. Os mais utilizados nos levantamentos elétricos são Wenner, Schlumberger e Dipolo-dipolo.

A técnica mais apropriada, sobretudo em áreas complexas, consiste na combinação sondagem-caminhamento, que permite definir tanto as variações verticais como horizontais de resistividade (Azambuja et al. 1999). 


\section{$\checkmark$ Polarização Induzida}

Segundo Sumner (1976) apud Elis (1998) a polarização induzida é um fenômeno elétrico estimulado por corrente, observado como reposta retardada a voltagem, em materiais naturais. Consiste na passagem de corrente elétrica, que quando cortada, o campo elétrico não desaparece imediatamente nem exponencialmente, mas de um modo lento, o que caracteriza a polarização induzida ou residual. A resposta da polarização induzida é medida, na prática, como uma variação de voltagem em função do tempo ou da freqüência, denominados, respectivamente, IP-Domínio do Tempo e IP-Domínio da Freqüência.

\section{$\checkmark$ Potencial Espontâneo}

O método de potencial espontâneo utiliza o campo natural, é baseado no fato de que em determinadas condições, heterogeneidades condutoras do subsolo se polarizam e originam correntes elétricas no solo.

Segundo Braga (1999), o potencial natural ou espontâneo é causado por atividades eletroquímicas ou mecânicas, sendo a água o agente mais importante desse mecanismo.

Esses potenciais podem ser gerados pela presença de corpos metálicos, contatos geológicos de matérias de diferentes condutividades, atividade bioelétrica de materiais orgânicos, gradientes térmicos e de pressão nos fluidos de subsuperfície (Gallas, 2000).

O equipamento utilizado restringe-se apenas ao circuito de recepção e a interpretação é realizada por mapas e seções de isovalores de potencial. Esse método pode ser utilizado para estudos ambientais, inclusive para determinação das direções de fluxo da água subterrânea.

$\checkmark$ Eletromagnético Indutivo

O método eletromagnético indutivo caracteriza-se pelo uso de equipamentos de operação muito simples e rápida (Figura 03 e 04), o que permite extensa aplicação da metodologia em estudos ambientais, como mapeamento de plumas de contaminação, intrusões salinas, exploração arqueológica, entre outros. 

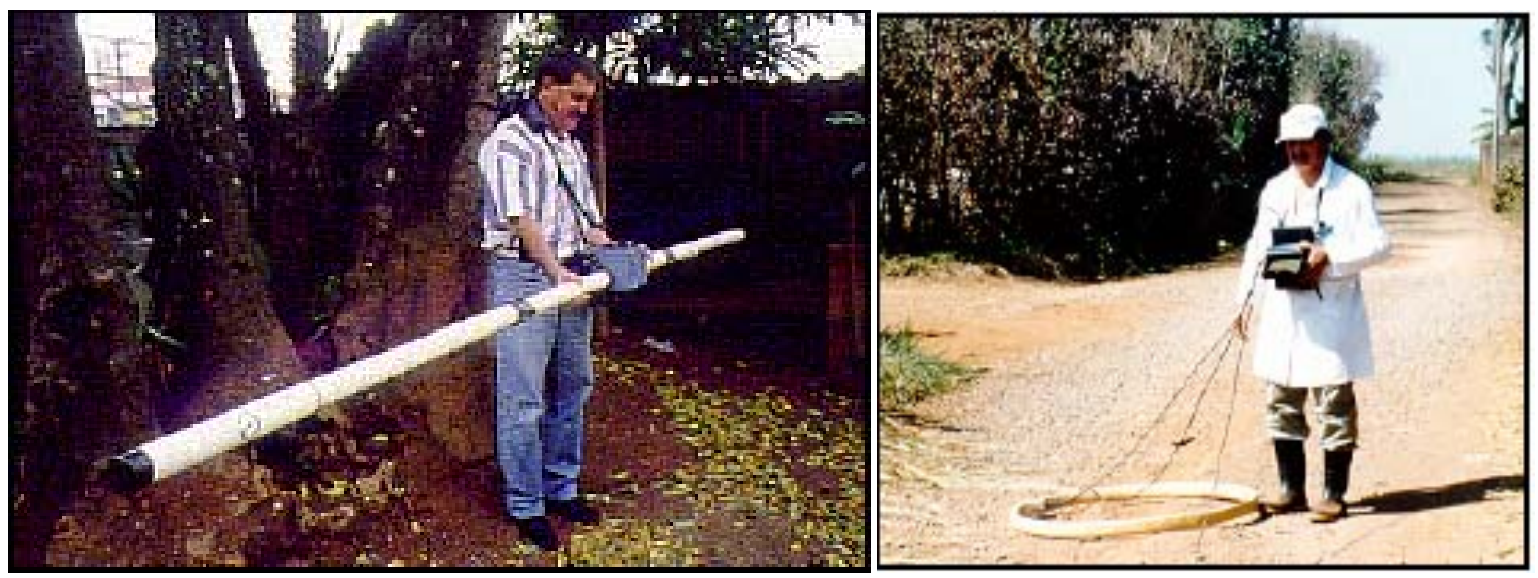

Figura 03 e 04: Exemplos de condutivímetros e modo de operação (CETESB, 2001).

O equipamento mede diretamente a condutividade dos materiais geológicos com base nos princípios da indução eletromagnética.

Segundo Yokoyama (2003), este sistema é composto por duas bobinas: uma transmissora $(T x)$ e outra receptora $(\mathrm{Rx})$. Acoplada à bobina transmissora há um módulo de controle e emissão de corrente elétrica, alimentado por uma bateria e na bobina receptora está acoplado um módulo de leitura, esses módulos são ligados por um cabo de referência.

A operação desse método consiste na injeção de uma corrente alternada na bobina transmissora, que gera um campo magnético primário, ortogonal a disposição da bobina. Esse campo magnético primário induz correntes elétricas no subsolo. Essas correntes, ao passar por um condutor, dão origem a um campo magnético secundário, que pode ser lido pela bobina receptora, juntamente com o campo magnético primário (Figura 05).

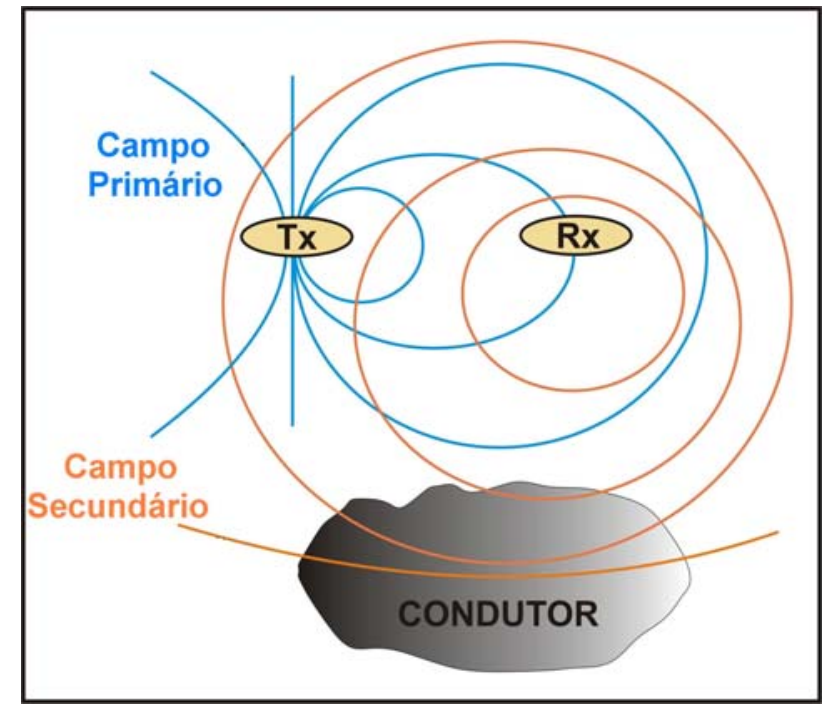

Figura 05: Princípio de operação do método eletromagnético indutivo (Yokoyama, 2003). 
Segundo CETESB (2001), o método eletromagnético indutivo apresenta as seguintes potencialidades na investigação de áreas contaminadas:

- Rápida aquisição de dados, resultando em levantamentos de alta densidade e definição;

- Instrumentos de registros contínuos podem aumentar a velocidade, densidade e definição dos levantamentos, permitindo a cobertura total do local investigado;

- Os limites da pluma de condutividade do solo ou das águas subterrâneas podem ser detectados e medidos;

- A faixa de profundidade de aquisição de dados varia de 0,75 a 60 metros, aproximadamente, dependendo do equipamento utilizado;

- As leituras são realizadas diretamente em unidades de condutividade elétrica (miliSiemens/m), possibilitando o uso direto dos dados de campo, e correlacionando-os à condutividade de amostras do solo e da água subterrânea;

- Capacidade de mapear variações das diferentes porções hidrogeológicas;

- A direção de fluxo da pluma de contaminação pode ser determinada através dos mapas e seções de isocondutividade;

- Medidas levantadas em épocas diferentes podem fornecer taxas da migração dos contaminantes no solo e na água subterrânea, contribuindo para o monitoramento local;

- Possibilidade de mapear minerações abandonadas, estimar seus volumes e detectar resíduos enterrados;

- Deteç̧ão e mapeamento de dutos metálicos enterrados.

$\checkmark$ Radar de Penetração (GPR)

O radar de penetração consiste na emissão continua de ondas eletromagnéticas e recepção dos sinais refletidos nas interfaces ou estruturas em subsuperfície.

O GPR produz uma onda eletromagnética de alta freqüência que é transmitida ao solo, onde a propagação do sinal depende das propriedades elétricas dos materiais existentes. Um pulso de energia é irradiado para o subsolo por intermédio de uma antena transmissora, sofrendo reflexões, refrações e difrações, sendo então captado por uma antena receptora (Gandolfo, 1999).

O sistema consiste, basicamente, de seis unidades: computador, unidade de controle, transmissor, receptor, antena transmissora e antena receptora (Figuras $06 \mathrm{e}$ 07). Tanto a unidade transmissora como a receptora são acopladas às antenas que, estão conectadas a unidade de controle por cabos de fibra ótica, que por sua vez é 
conectada a um computador portátil, que envia sinais para o módulo transmissor e receptor, permitindo assim uma visualização quase que imediata do sinal registrado (Yokoyama 2003).

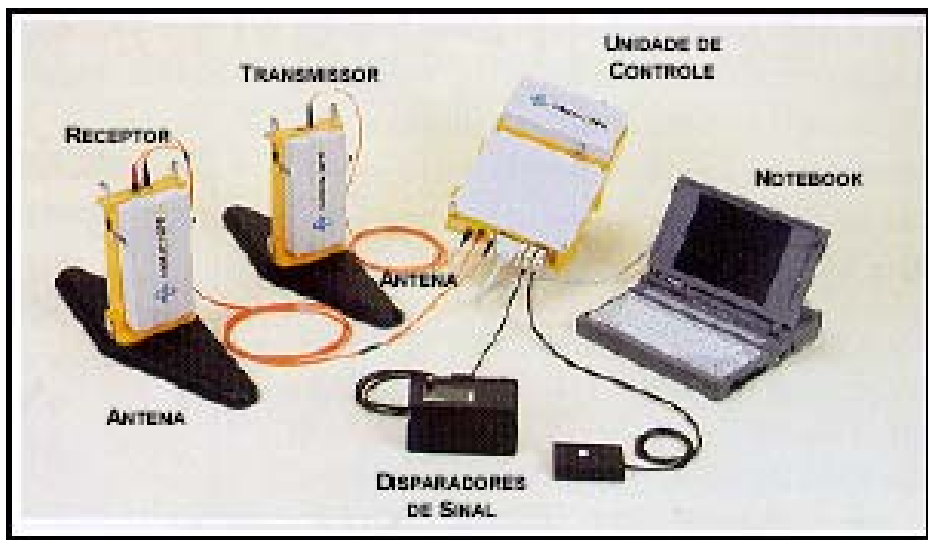

Figura 06: Equipamento para operação do radar de penetração (CETESB, 2001).

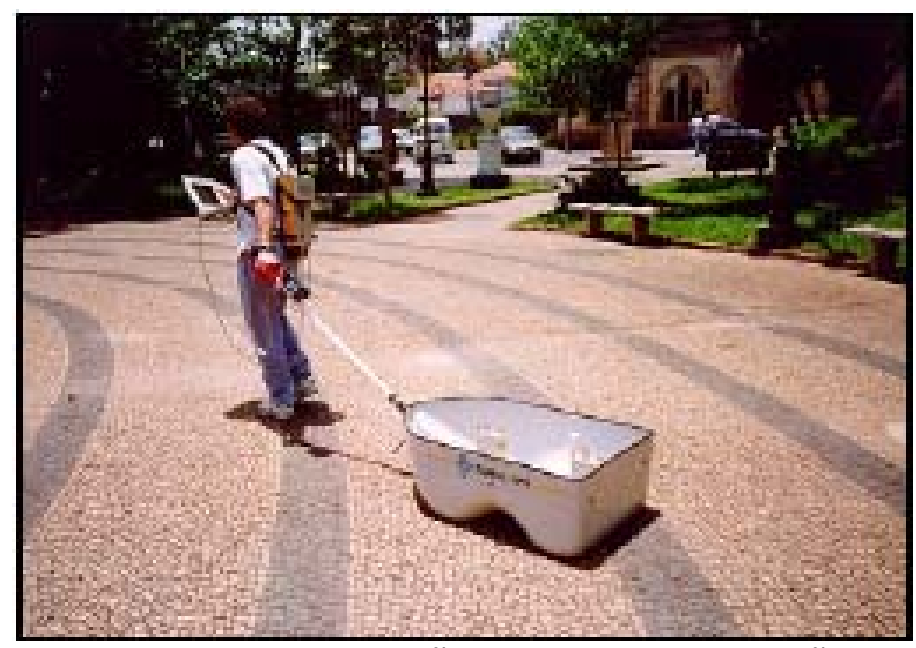

Figura 07: Exemplo de modo de operação do radar de penetração (CETESB, 2001).

O radar de penetração, segundo CETESB (2001), apresenta as seguintes potencialidades na investigação de áreas contaminadas:

- Realização de perfis ao longo de linhas, produzindo seções contínuas e instantâneas;

- A faixa de velocidade varia de 0,5 a $2,0 \mathrm{~km} / \mathrm{h}$ para perfis detalhados e velocidades superiores a $8,0 \mathrm{~km} / \mathrm{h}$ em perfis de reconhecimento;

- Os registros gráficos podem ser interpretados no campo;

- Boa definição para corpos de poucos centímetros a 1 metro, dependendo da antena a ser utilizada;

- Adequação do equipamento às condições locais através da mudança de antenas (altas freqüências obtêm melhor definição, baixas freqüências fornecem maior profundidade de investigação); 
- Profundidades aproximadas e relativas são facilmente estabelecidas, assumindo-se simples condições e técnicas de interpretação;

- Possibilidade de deteç̧ão de contaminação por compostos orgânicos;

- Utilização do método em áreas urbanas;

- Aplicabilidade sobre água, concreto, asfalto ou qualquer outro tipo de superfície, com exceção das superfícies metálicas e água do mar);

- Uma ampla variedade de técnicas de processamento pode ser aplicada aos dados de radar, para aperfeiçoar a interpretação e apresentação;

- Capacidade de detecção de dutos ou galerias subterrâneas de qualquer tipo de material;

- Possibilidade de identificação de vazamentos em tubulações.

$\checkmark$ Métodos geoelétricos no estudo de contaminação de águas subterrâneas

Cada método geoelétrico, que pode ser utilizado na investigação de contaminação, é aplicado visando sua melhor resposta e definição, para tanto deve-se analisar as condições locais e objetivos da investigação, adequando assim o melhor método, na Tabela 2 é exposto um resumo de algumas situações e métodos indicados.

Tabela 02: Comparativo de aplicações dos métodos geoelétricos (adaptado de CETESB, 2001 e Braga, 1999).

\begin{tabular}{|c|c|c|c|c|c|}
\hline $\begin{array}{c}\text { Caracterização } \\
\text { geológica }\end{array}$ & $\begin{array}{c}\text { Eletrorresis- } \\
\text { tividade }\end{array}$ & $\begin{array}{c}\text { Polarização } \\
\text { I nduzida }\end{array}$ & $\begin{array}{c}\text { Potencial } \\
\text { espontâneo }\end{array}$ & $\begin{array}{c}\text { Eletromag- } \\
\text { nético }\end{array}$ & $\begin{array}{c}\text { Radar de } \\
\text { Penetração }\end{array}$ \\
\hline \hline $\begin{array}{c}\text { Direção de } \\
\text { fluxo da água }\end{array}$ & adequado & adequado & adequado & adequado & $\begin{array}{c}\text { não } \\
\text { recomendado }\end{array}$ \\
\hline $\begin{array}{c}\text { Detecção de } \\
\text { contaminação }\end{array}$ & adequado & alternativo & adequado & adequado & alternativo \\
\hline $\begin{array}{c}\text { Espessura do } \\
\text { aqǘŕfero }\end{array}$ & adequado & alternativo & recomendado & alternativo & alternativo \\
\hline $\begin{array}{c}\text { Determinação } \\
\text { do nível } \\
\text { d' água }\end{array}$ & adequado & recomendado & recomendado & alternativo & adequado \\
\hline
\end{tabular}

Segundo CETESB (2001), devido à alta condutividade elétrica apresentada pelas argilas, o contraste entre o valor da condutividade natural do meio e a condutividade dos contaminantes inorgânicos pode ser pequeno, podendo mascarar a deteç̧ão da contaminação. Além disso, a presença de argila atenua a propagação dos campos e ondas eletromagnéticas, reduzindo a profundidade de investigação dos 
métodos eletromagnéticos indutivos e do radar de penetração, que atingem suas maior profundidades de investigação em terrenos arenosos.

Os sedimentos superficiais não consolidados e os materiais intemperizados tendem a apresentar maior resistividade e menor teor de argila em relação aos materiais mais compactados. Assim, esse tipo de meio favorece a aplicação dos métodos de eletrorresistividade, eletromagnético indutivo e o radar de penetração.

A aplicação dos métodos geofísicos elétricos em investigações hidrológicas e ambientais é bastante difundida (Buselli et al. 1990). Em estudos ambientais, particularmente na avaliação de áreas de disposição de resíduos sólidos, tanto na identificação litológica dos materiais de sub-superfície, como na estimativa da profundidade do lençol freático e sentido do fluxo da água subterrânea, os métodos de eletrorresistividade, polarização induzida e potencial espontâneo podem ser empregados a custos e prazos relativamente reduzidos, sem alterar o meio físico.

A inclusão da geofísica elétrica em estudos hidrogeológicos convencionais possibilita uma visão mais completa e, portanto mais segura da área, uma vez que os métodos fornecem informações sobre a subsuperfície de maneira extensiva e praticamente contínua com um mínimo de impacto ambiental. Além disso, esta técnica é uma forma otimizada para efetuar o monitoramento e proteger a qualidade dos recursos hídricos, em áreas de elevados riscos de poluição subterrânea. (Cavalcanti et al. 2002).

Ellert et al. (1986) utilizou métodos geofísicos para a determinação da profundidade e extensão da migração de agentes poluentes, bem como os locais de maior concentração em aterro sanitário (Santo André -SP) e em área de rejeito industrial (vinho em Novo Horizonte-SP). Indica a aplicabilidade do método para fins de locação da extensão e da intensidade de contaminação do subsolo.

Mendes (1987) aplicou sondagem elétrica vertical, caminhamento elétrico, sondagem eletromagnética e caminhamento eletromagnético no mapeamento e monitoramento da poluição de águas subterrâneas gerada por aterros sanitários, áreas de infiltração da vinhaça, intrusão de água salgada em aqüíferos costeiros e áreas com infiltração e vazamentos de produtos e efluentes industriais, em varias regiões do estado de São Paulo. Concluiu a viabilidade da utilização de técnicas geofísicas no mapeamento e monitoramento de poluição e contaminação de águas subterrâneas.

Cottas et al. (1991) definiu a superfície e o fluxo do lençol freático, para orientar a instalação de piezômetros em um aterro em Rio Claro - SP, utilizando sondagens elétricas, e concluiu a eficiência do método para tal aplicação. 
Elis (1993) aplicou caminhamento elétrico na definição de limites da cava preenchida por lixo, em um lixão desativado em Ribeirão Preto - SP. Concluiu que o método geofísico utilizado se presta bem para fins de definição da área de resíduos e contaminantes em subsuperfície.

Malagutti Filho et al. (1997) com utilização de caminhamento elétrico, sondagens elétricas, sísmica de refração e eletromagnético indutivo, caracterizou os materiais geológicos, resíduos, nível d'água e fluxo subterrâneo no aterro controlado de Rio Claro - SP e também percebeu a eficiente aplicabilidade dos métodos geofísicos para os fins utilizados.

Mota e Fialho Rodrigues (1998) caracterizaram sub-superficialmente um aterro desativado, instalado em meio cárstico e puderam detectar focos de contaminação com o auxílio da eletrorresistividade, comprovando a aplicabilidade dos métodos geofísicos elétricos para identificação de tais contrastes.

Elis e Zuquette (2002) aplicaram o caminhamento elétrico e puderam mapear de maneira eficiente a zona contaminada e com sondagens elétricas determinaram a profundidade da zona saturada e a espessura dos materiais inconsolidados e resíduos no lixão desativado e no aterro sanitário de Ribeirão Preto - SP.

Mendes e Verma (2002) utilizaram diferentes métodos geofísicos na pesquisa hidrogeológica, com intuito de minimizar interpretações ambíguas, na prospecção de água subterrânea na região de Belém (PA) e puderam caracterizar duas zonas aqüíferas distintas na região de Belém, comprovando a aplicação eficiente dos métodos utilizados.

Cavalcanti et al. (2002) aplicaram sondagem elétrica vertical, polarização induzida e potencial espontâneo para a avaliação das condições hidrológicas subterrâneas na região do novo aterro sanitário de Salvador - BA, antes de sua efetiva utilização, obtendo bons resultados, que permitiram uma caracterização consistente do local.

Carbonell, et al. (2002) utilizou, com sucesso, métodos geofísicos para determinação de uma pluma de contaminação em um aqüífero superficial na Base Área Militar de Wurstmith em Oscoda, Michigan, USA. Percebeu a eficiência dos métodos utilizados, mostrando vantagens oferecidas, como a investigação de grandes extensões em tempo relativamente pequeno. 


\section{Localização e Características Gerais da Área de Estudo}

\subsection{Localização}

A área de estudo, na qual insere-se o lixão desativado de São Carlos, localizase na Fazenda Santa Madalena, no município de São Carlos, no estado de São Paulo. Fica situada entre as coordenadas UTM 209678-210361 Leste e 7555344-7554535 Norte.

O município de São Carlos limita-se ao norte com os municípios de Rincão, Luís Antônio e Santa Lúcia; ao sul com Ribeirão Bonito, Brotas e Itirapina; a oeste com I baté, Araraquara e Américo Brasiliense e a leste com Descalvado e Analândia.

Segundo a Prefeitura Municipal de São Carlos (2005), a área estudada inserese na Área de Proteção Ambiental (APA) Corumbataí, como pode ser observado na Figura 08.

O lixão desativado fica cerca de $20 \mathrm{~km}$ do centro da cidade de São Carlos, o acesso pode ser feito pela rodovia Washington Luís (SP-310) no sentido São Carlos São Paulo por aproximadamente $17 \mathrm{~km}$, tomando-se estrada vicinal a leste, aproximadamente no km 221 da rodovia, em direção ao município de Analândia por mais $3 \mathrm{~km}$, conforme representado na Figura 08. 


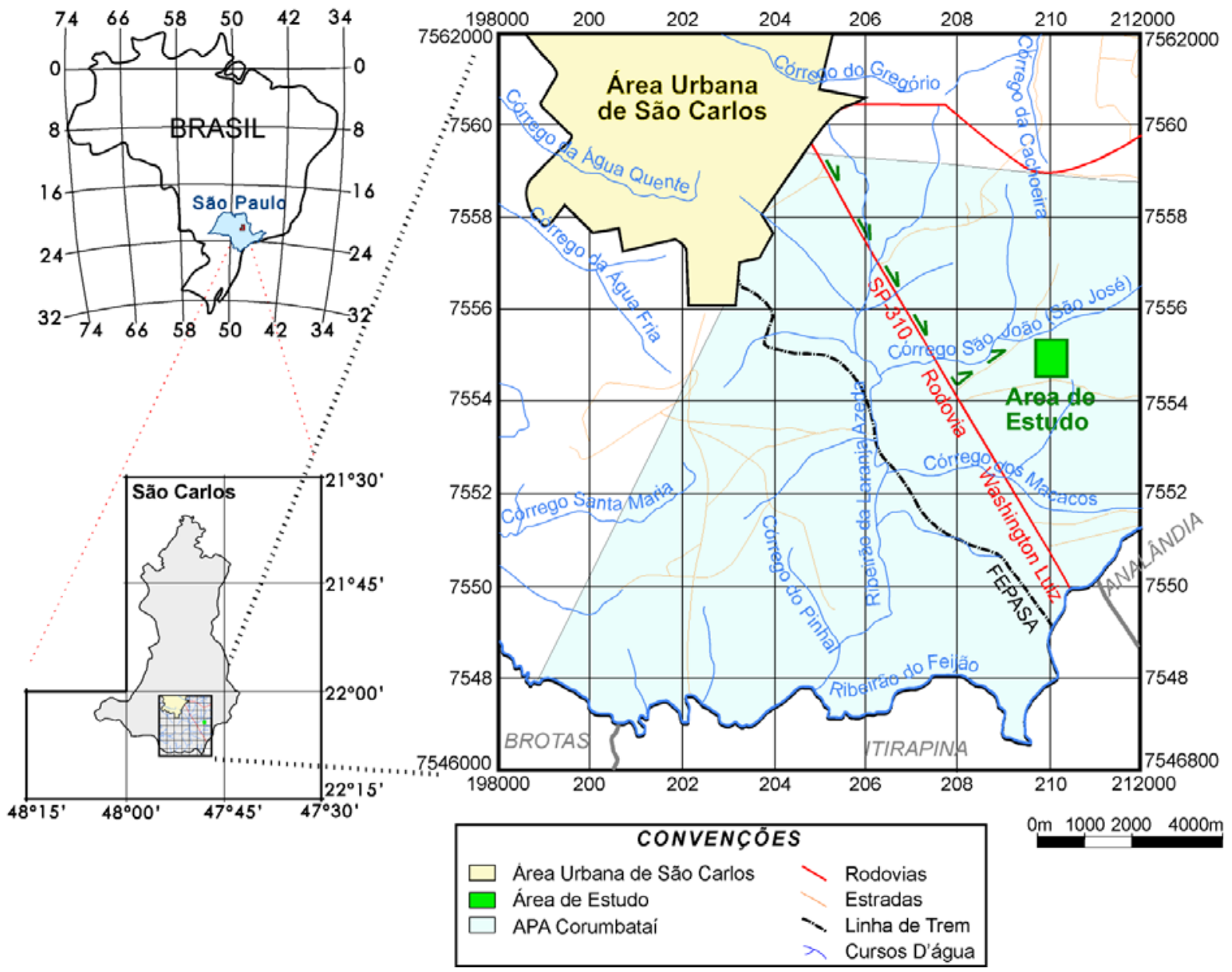

Figura 8: Localização da área de estudo (modificado de Gonçalves, 1986; Muro, 2000 e Prefeitura Municipal de São Carlos, 2005).

\subsection{Clima}

Clima pode ser definido como o conjunto de ocorrências metereológicas que caracterizam as condições médias em uma determinada região da superfície do globo terrestre.

A área de estudo localiza-se na zona considerada como tropical de altitude, no domínio de clima Cwa da classificação de Köeppen, que é caracterizado por clima quente com inverno seco, no qual a temperatura média do mês mais frio é inferior a $18^{\circ} \mathrm{C}$ e a do mês mais quente ultrapassa $22^{\circ} \mathrm{C}$ (Miranda, 2005).

Segundo Miranda (2005), já ocorreram temperaturas extremas com mínimas de $-0,3 \circ \mathrm{C}$ (em 27/6/94) e máximas de 35,8ㅇ (em 26/11/91). Sendo que as médias diárias variam de 5,5 a $28,1^{\circ} \mathrm{C}$, as médias mensais de 17,3 a $23,6 \circ \mathrm{C}$, e as médias anuais entre 20,8 e 21,7 으. 
No mês mais seco o total das chuvas não chega a atingir $30 \mathrm{~mm}$, enquanto que do mês mais chuvoso atinge valores dez ou mais vezes maiores do que os do mês mais seco. Embora o período seco seja de junho a agosto, de maneira geral varia num período de seis meses, de junho a novembro, com déficit hídrico mais intenso, ou de abril a setembro, considerando o período com menos chuvas (Miranda, 2005).

A precipitação pluvial máxima mensal é de $470 \mathrm{~mm}$, com até 26 dias chuvosos, e a máxima diária de 104,6 mm, com valores acumulados anuais variando entre 1.138 e $1.593 \mathrm{~mm}$, concentrada de outubro a março (Miranda, 2005).

Segundo Tolentino (1967) os ventos predominantes no município sopram de nordeste $(30,2 \%$, em fevereiro e março), sudeste $(19,4 \%$, de setembro a novembro e abril), leste (14,8\%, de maio a julho) e norte (12,3\%, em janeiro), com médias de velocidades, respectivamente de $3,5,4,0,3,1$ e $3,1 \mathrm{~m} . \mathrm{s}^{-1}$. Os ventos menos freqüentes sopram de noroeste $(8,2 \%)$, oeste $(5,9 \%)$, sul $(4,7 \%)$ e sudoeste $(5,9 \%)$, com médias de velocidades de 3,3, 3,0, 3,3 e 2,9 m.s ${ }^{-1}$, respectivamente. A média mensal da pressão atmosférica varia de 913 a 923 milibares.

Segundo Miranda (2005) a média diária da umidade relativa do ar varia entre 30 e 100\%, com médias mensais entre 53 e 89\%, e médias anuais entre 71 e $77 \%$.

\subsection{Geomorfologia}

A geomorfologia de uma região é resultante da atuação de processos da dinâmica interna da Terra e da interação da ação do sol, da água e da litologia. A localização geomorfológica geral da área de estudo pode ser observada na imagem de satélite da Figura 09. 


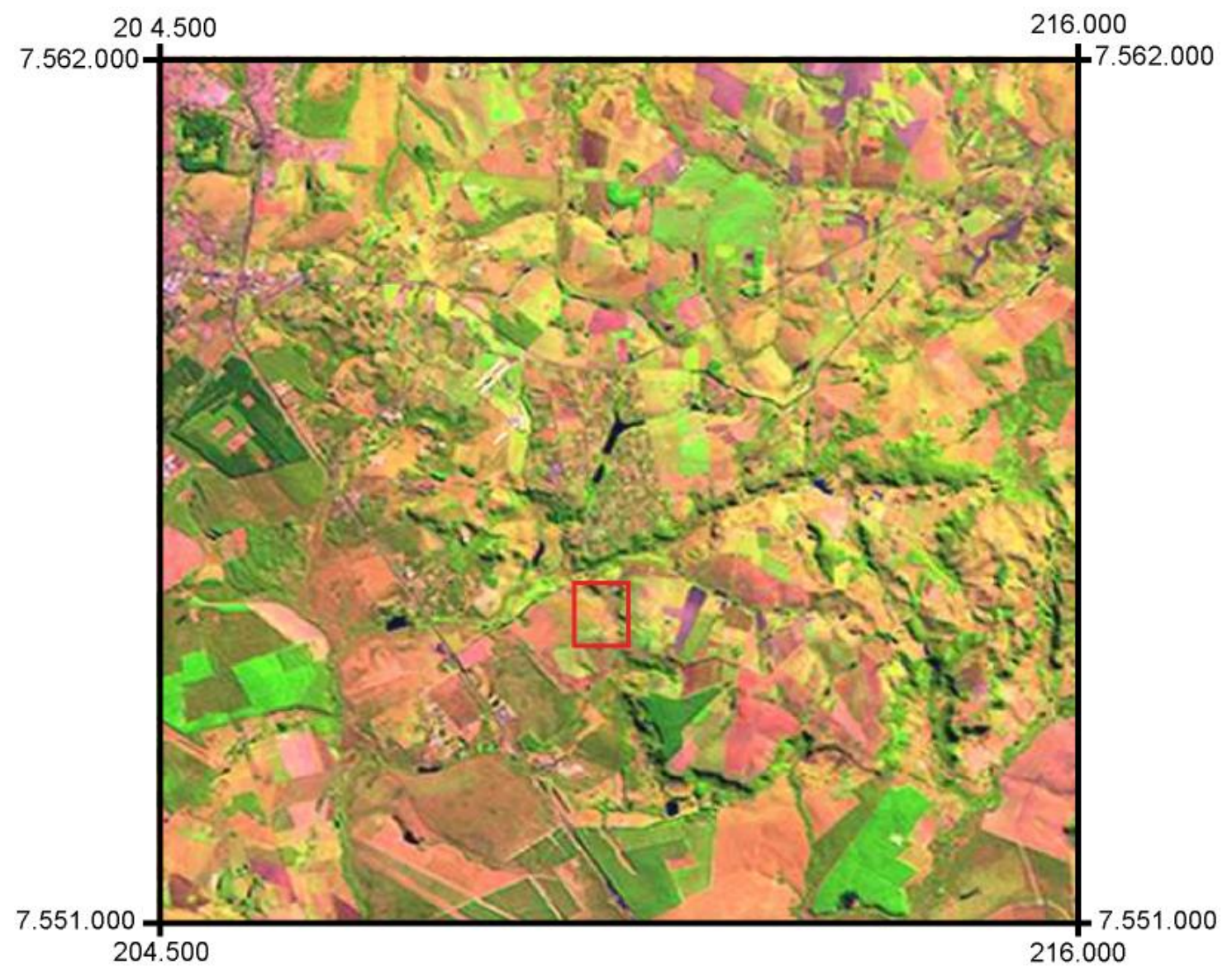

Figura 09: Localização da área de estudo em imagem de satélite (Imagem Landsat 7 - Miranda e Coutinho, 2001).

De acordo com aproposta de Almeida (1964) o Estado de São Paulo foi dividido em cinco províncias geomorfológicas: Planalto Atlântico, Província Costeira, Depressão Periférica, Cuestas Basálticas e Planalto Ocidental, sendo que a área de estudo localiza-se na província de Cuestas Basálticas, como indicado na Figura 10.

Segundo IPT (1981) as cuestas constituem uma das feições mais marcantes do relevo paulista. São formas de relevo sustentadas por rochas basálticas e caracterizadas por exibirem escarpas nos seus limites com a depressão periférica, seguidas de uma sucessão de grandes plataformas estruturais de relevo suavizado, inclinadas para o interior em direção a calha do Rio Paraná. Internamente as plataformas apresentam escarpas menores, dando um caráter misto de colinas e escarpas ao relevo geral.

Os reversos das cuestas formam feições geomorfológicas que receberam a designação de Planaltos Residuais e foram divididas em cinco setores por Ross e Moroz (1997), sendo que a área de estudo situa-se no Planalto Residual de São Carlos, localizada no interfluvio Tietê/Mogi-Guaçu. 


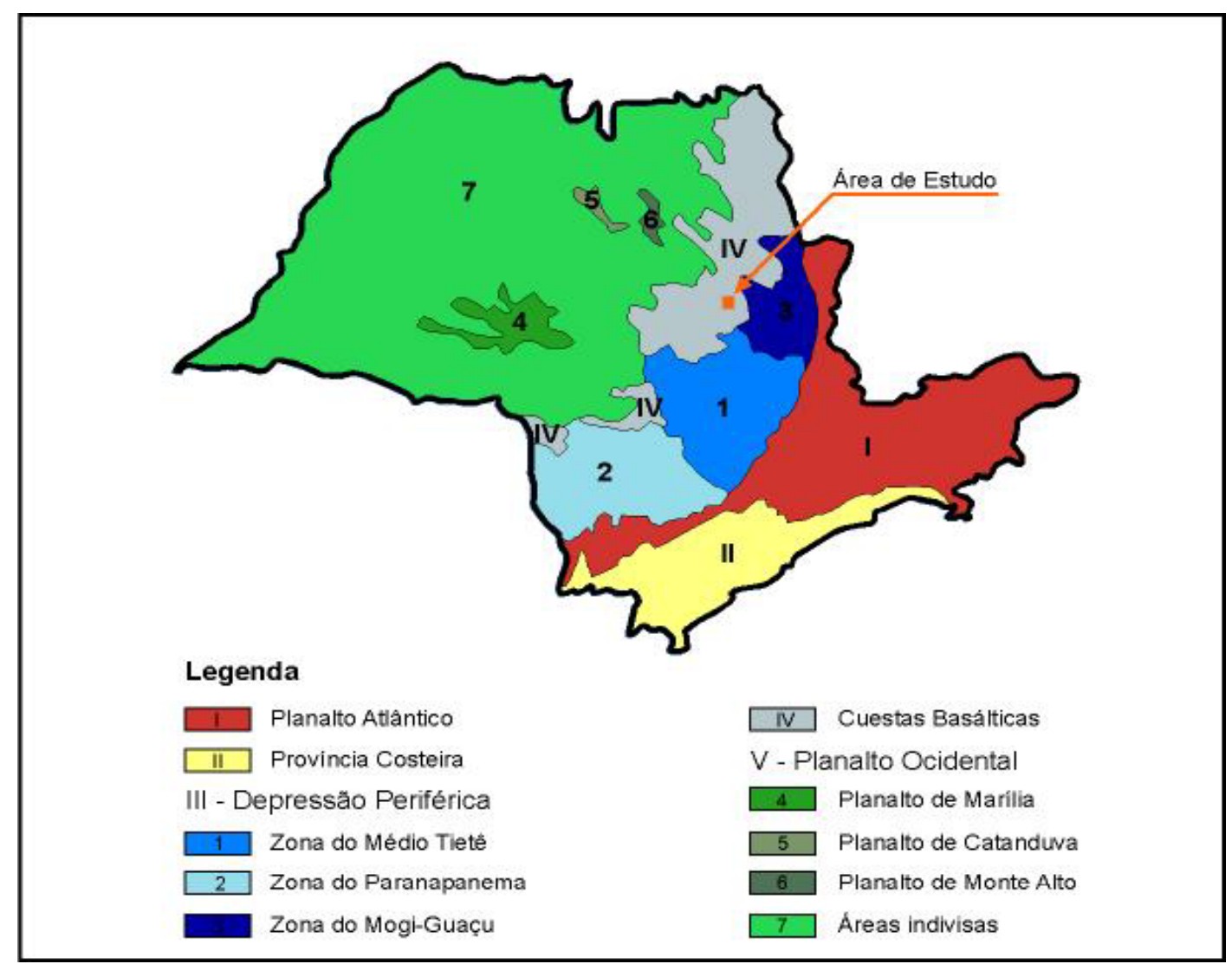

Figura 10: Localização da área de estudo na província de Cuestas Basálticas, segundo Almeida, 1964.

Segundo Ross e Moroz (1997) as altitudes do Planalto residual de São Carlos variam de 600 a $900 \mathrm{~m}$, com vertentes de baixa declividade, entre 2 e $20 \%$, atingindo $30 \%$ apenas nas porções de relevo mais dissecadas. As formas de relevo predominante são as denudacionais, basicamente formadas por colinas de topos convexos e tabulares. Os vales têm entalhamentos que variam de 20 a $80 \mathrm{~m}$ e a dimensão média interfluvial varia de 250 a 3750m. Nessa área a densidade de drenagem é classificada como média a alta.

\subsection{Vegetação}

Segundo Miranda (2005) no município de São Carlos correm os seguintes tipos de vegetação: savana, floresta estacional, floresta secundária e vegetação ripária, além de áreas de reflorestamento.

Segundo SMA/SP (2004), na região do município de São Carlos, a vegetação apresenta a distribuição ilustrada na Figura 11. 


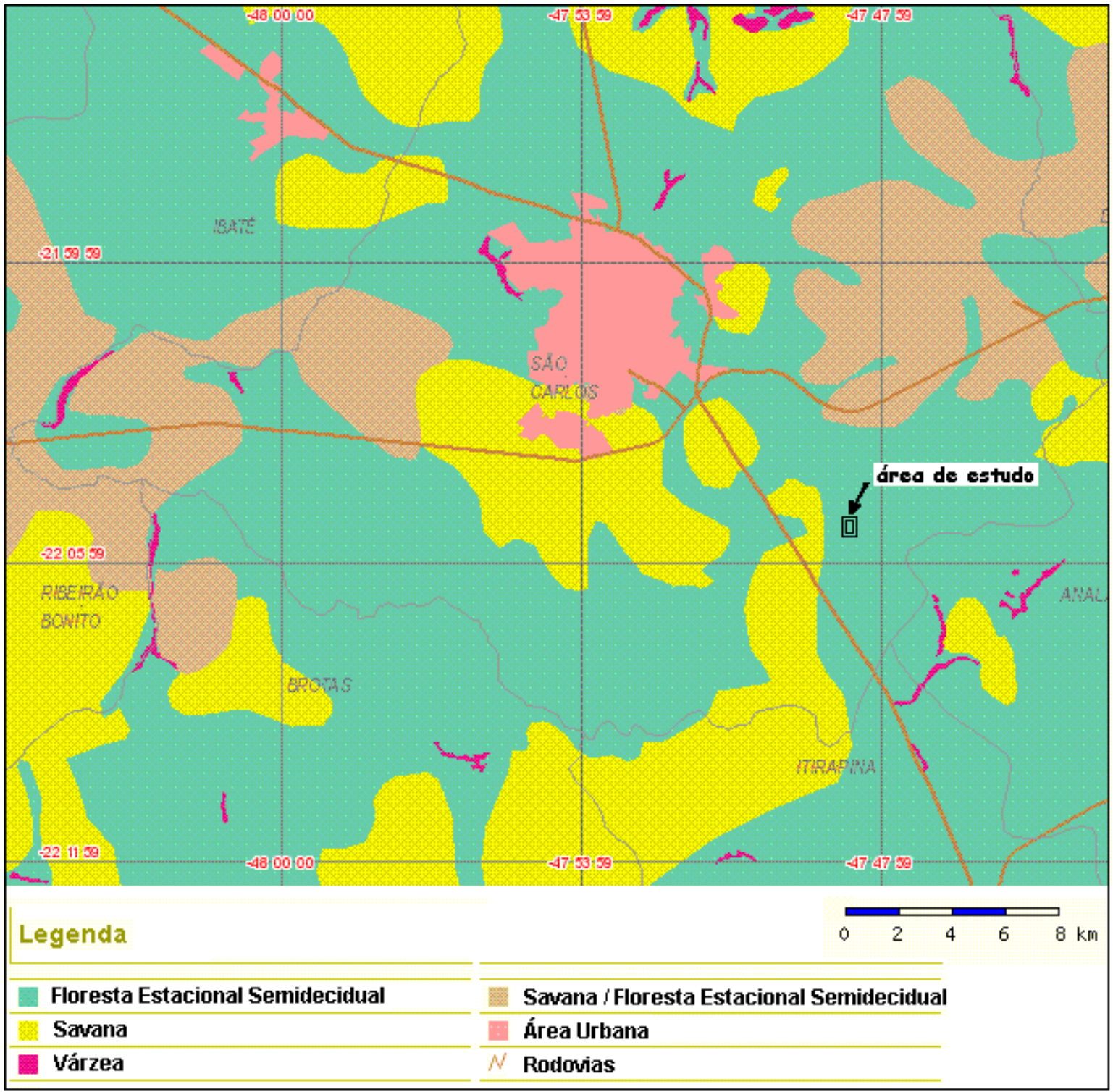

Figura 11: Vegetação na região do município de São Carlos, com indicação da área de estudo (modificado de SMA/SP, 2004).

A floresta estacional semidecidual está condicionada a estacionalidade climática (verão chuvoso e inverno seco ou clima subtropical sem seca, mas com intenso frio, temperaturas médias abaixo de $15 \circ \mathrm{C}$ ) e pela queda das folhas durante o período seco, em 20 a 50\% das árvores caducifólias da floresta. Hoje, as pequenas extensões de florestas estacionais semidecíduais correspondem às Unidades de Conservação e a matas residuais em propriedades privadas (IBGE, 1991).

Atualmente na área de estudo a vegetação existente é o capim "brachiaria", com áreas de pastagem de búfalos e porções ocupadas com o plantio de goiabas. 


\subsection{Pedologia}

A classe de solos predominante na área de estudo, assim como no Estado de São Paulo ( $52 \%$ da área do Estado), é a dos Latossolos, em relevo pouco declivoso (Miranda, 2005). Na Figura 12 pode ser observada a distribuição das classes de solos que ocorrem na região do município de São Carlos, assim como na área de estudo.

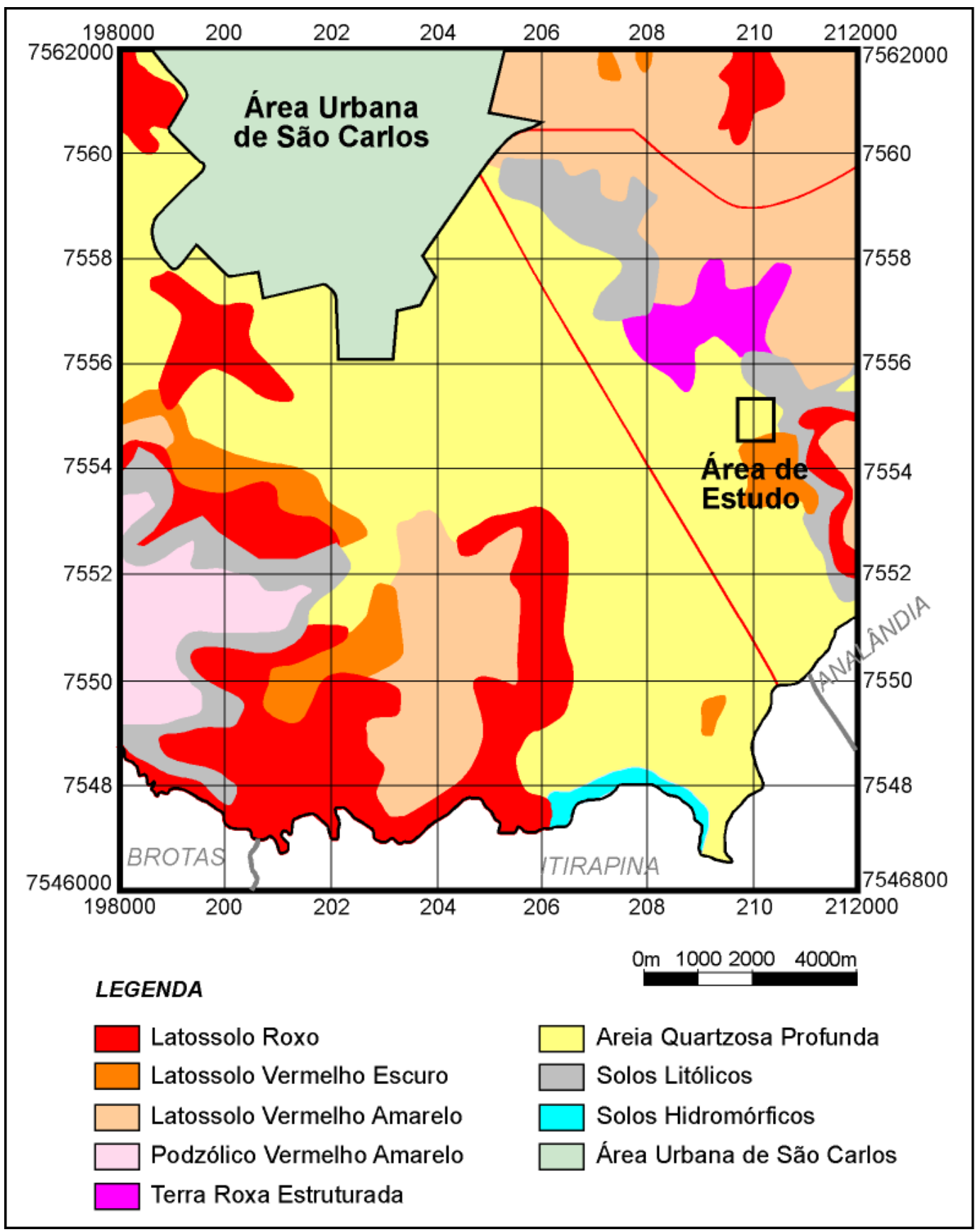

Figura 12: Solos presentes na região do município de São Carlos, com indicação da área de estudo (modificado de Secretaria Municipal de Desenvolvimento Sustentável, Ciência e Tecnologia - baseado no levantamento pedológico semi-detalhado de estado de São Paulo apud Prefeitura Municipal de São Carlos, 2005). 
Os Latossolos Roxos (LR) são solos bem drenados, com seqüência de horizontes A-B-C e pequena diferenciação entre horizontes. São solos de coloração vermelho-arroxeada, argilosos, bastante porosos e profundos, com pequena variação de cor entre os horizontes. Apresentam saturação de bases variável, sendo que a fertilidade natural pode ser alta ou baixa. Os teores de óxido de ferro e manganês são altos (Lepsch, 1994).

Os Latossolos Vermelho Escuros (LE, LEa) são solos bem drenados, com seqüência de horizontes $A-B-C$ e pequena diferenciação entre horizontes. São solos de coloração vermelho escura, ácidos, com saturação de bases baixa e com teores de óxido de ferro intermediários entre o latossolo roxo e o latossolo vermelho amarelo (Lepsch, 1994).

Os Latossolos Roxo e Vermelho Escuro estão relacionados à classe de Latossolos Vermelhos, segundo Oliveira (1999).

Os Latossolos Vermelho Amarelos (LV, LVa) são solos bem drenados, com seqüência de horizontes $A-B-C$, pequena diferenciação entre horizontes, relação textural (\% de argila do horizonte B / \% de argila do horizonte A) em torno de 1,3. Apresentam coloração de amarela até vermelha, ácidos, com saturação de bases baixa e baixos teores de óxidos de ferro (Lepsch, 1994).

Esta classe de solo está relacionada aos Latossolos Vermelho-Amarelos, segundo Oliveira (1999). Geralmente são solos profundos, em relevo suavemente ondulado a quase plano.

Os solos Podzólicos Vermelho Amarelos (PV, PVp, PVIs) são solos bem drenados, com seqüência de horizontes A-E-B-C e nítida diferenciação entre os horizontes. Apresentam o teor de argila do horizonte $B$ bem mais elevado que dos horizontes superficiais. São ácidos e com saturação de bases baixa (Lepsch, 1994).

De acordo com Oliveira (1999) esse solo podzolizado pode ser relacionado à classe dos Argissolos (Vermelho-amarelos). Os Argissolos compreendem grande área do Estado de São Paulo, sendo considerada a classe de maior expressão espacial, depois dos Latossolos.

As Areias Quartzosas ou Regossolos ( $R$ ) são solos pouco desenvolvidos, constituídos de um horizonte A assentado sobre um horizonte $\mathrm{C}$, profundo e arenoso, o material de origem constitui-se de arenitos (Lepsch, 1994). De acordo com Oliveira (1999) os regossolos estão relacionados à classe Neossolos Quartzarênicos. Em geral são solos profundos e muito porosos, porém desprovidos de minerais primários intemperizáveis.

Os Solos Litólicos ou Litossolos (Ligr, Liac) são solos muito rasos, pouco desenvolvidos, constituídos pelo horizonte superficial, de pequena espessura, formado 
com acumulação de matéria orgânica, seguido de rochas pouco alteradas, consolidadas ou semibrandas (Lepsch, 1994). Estes solos estão relacionados à classe Neossolos Litólicos, segundo Oliveira (1999).

Os Solos hidromórficos ( $\mathrm{Hi}$ ) são solos intrazonais, nos quais as características equivalentes dos solos zonais não se desenvolveram, em grande parte devido à grande influência da água no perfil. Essa influência da água está condicionada, principalmente, pelo relevo (Lepsch, 1994). Estes solos estão relacionados aos Gleissolos, de acordo com Oliveira (1999). Os Gleissolos apresentam sérias limitações em função da presença de lençol freático e da pouca profundidade, além do encharcamento.

\subsection{Hidrologia}

\subsection{1. Águas Superficiais}

Os rios são as principais unidades morfológicas da bacia hidrográfica e interagem diretamente com a atmosfera e seu entorno. As bacias hidrográficas são unidades naturais da paisagem, refletindo os recursos presentes e as atividades interligadas e interdependentes, não sendo delimitadas por limites políticos (Miranda, 2005).

A área de estudo insere-se na macrobacia hidrográfica do Tietê-Jacaré, na bacia do Feijão (Figura 13). A Bacia do Feijão é responsável por $40 \%$ do abastecimento da água de São Carlos, além de ser área de recarga do Aqüífero Guarani.

Uma das fontes de degradação da qualidade da água dos cursos formadores da bacia é a presença do lixão (área de estudo), situado sobre nascentes da sub-bacia do Córrego São José (Menezes, et al., 1995).

Segundo Ferrante (1990) a Bacia do Feijão apresenta drenagem bastante densa, do tipo dendrítica, sendo o Córrego São José um canal de ordem 3, com densidade hidrográfica alta. 


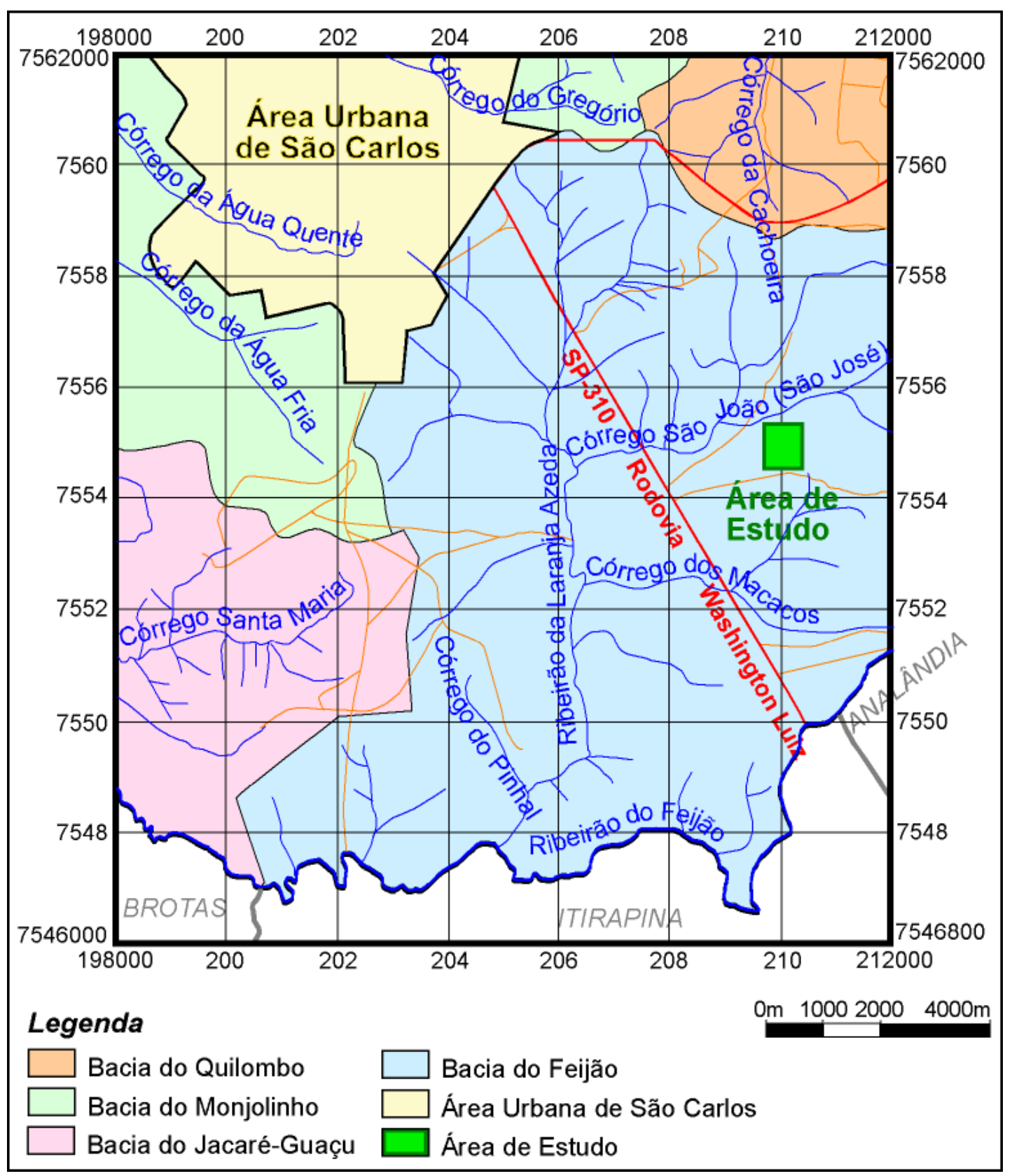

Figura 13: Divisão de bacias hidrográficas na região da área de estudo (baseado em Prefeitura Municipal de São Carlos, 2005).

Segundo dados de Rios (1993) a qualidade do Córrego São José variou de boa a muito boa na região a montante do lixão, tornando-se péssima imediatamente após a passagem pelo lixão, nessa região pode ser observada a presença de resíduos carreados até o local nos períodos de chuvas intensas (Figura 14). 


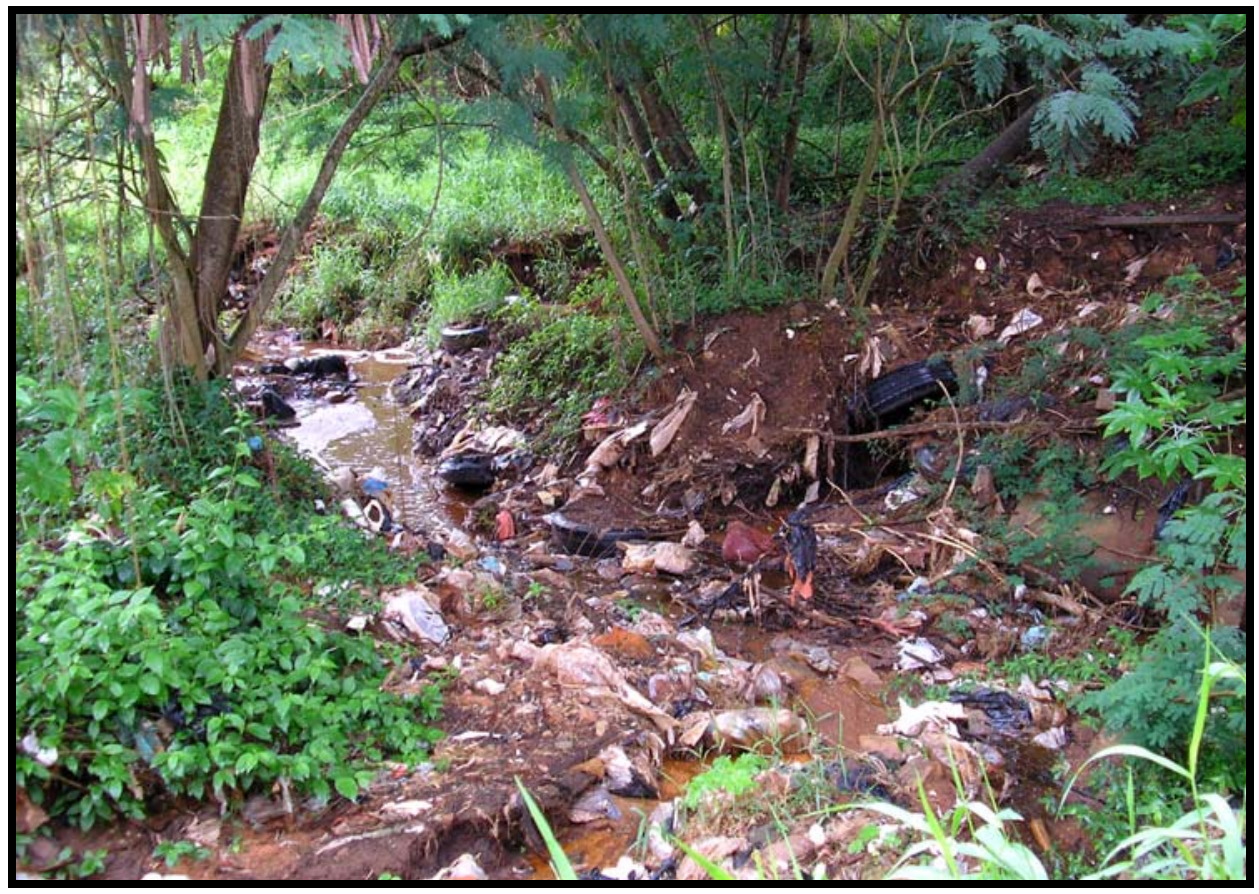

Figura 14: Foto da situação atual, com presença de resíduos, no córrego a jusante do corpo do lixo.

Após atravessar extensa várzea à jusante do lixo, a qualidade variou de boa a pobre. Segundo Matheus et al. (1992) essa melhora de qualidade se deve a várzea, que representa um filtro biológico e ecológico.

\subsection{2. Águas Subterrâneas}

O estado de São Paulo situa-se sobre um grande manancial de água subterrânea, o Aqüífero Guarani, de grande importância na captação de água para abastecimento.

De acordo com a EMBRAPA (2004), a água contida nesse aqüífero é de excelente qualidade e suficiente para abastecer a atual população brasileira por 2.500 anos. É a maior reserva de água doce subterrânea do mundo. Sua área se estende por 1,15 milhões de quilômetros quadrados, sendo a maior parte (71\%) localizada sob território brasileiro. Em seguida vem a Argentina, com 19\%, o Paraguai com $6 \%$ e o Uruguai com $4 \%$.

No Brasil, ele está presente nos estados de São Paulo, Mato Grosso, Mato Grosso do Sul, Paraná, Rio Grande do Sul, Santa Catarina, Minas Gerais e Goiás (Figura 15).

O Aqüífero Guarani, de acordo com a EMBRAPA (2004), tem recarga de 140 bilhões de metros cúbicos por ano, mas apenas 40 bilhões de metros cúbicos poderiam ser utilizados, para que a sustentabilidade do lençol freático fosse mantida e não existem dados seguros que comprovem o quanto já é consumido. 


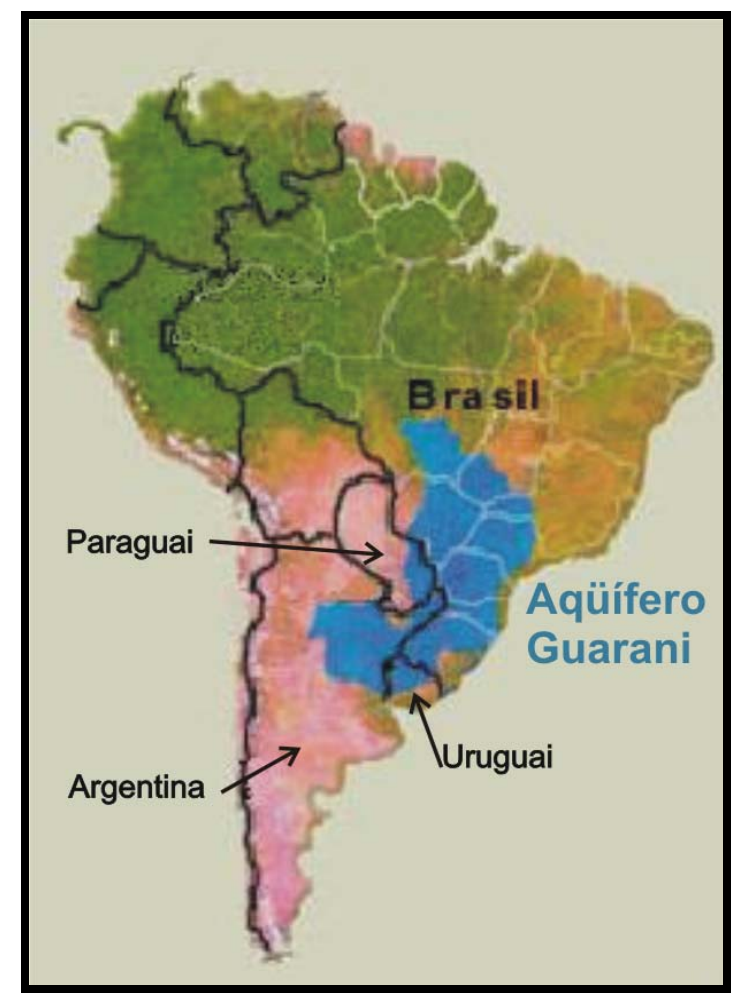

Figura 15: Localização do Aqüífero Guarani (CETESB, 2004).

O aqüífero Botucatu é um dos mais importantes mananciais de água subsuperficial do estado de São Paulo, assim como do país, não só pela sua grande área de ocorrência como também pela qualidade fisico-química de suas águas. Além de apresentar $90 \%$ de sua área recoberta pelos derrames básicos da Formação Serra Geral, o que o torna confinado em quase toda a sua extensão. O sistema aqüífero encontra-se sobreposto ao Grupo Passa Dois, que funciona como um substrato impermeável e apresenta mergulho geral para oeste, em direção à calha do Rio Paraná (Davino et al., 1982).

Silva (1983) definiu alguns parâmetros hidráulicos e hidrogeoquímicos desse aqüífero:

- capacidade específica: encontra-se em $30 \%$ dos casos abaixo de $1 \mathrm{~m}^{3} / \mathrm{h} / \mathrm{m}$, em $38 \%$ entre 1 e $5 \mathrm{~m}^{3} / \mathrm{h} / \mathrm{m}$ e nos $32 \%$ restante acima de $5 \mathrm{~m}^{3} / \mathrm{h} / \mathrm{m}$;

- transmissividade: varia de $4,7 \mathrm{E}^{-4}$ a $1,5 \mathrm{E}^{-2} \mathrm{~m}^{2} / \mathrm{s}$;

- condutividade hidráulica: oscila entre $2,4 \mathrm{E}^{-6}$ e $4,5 \mathrm{E}^{-5} \mathrm{~m} / \mathrm{s}$;

- armazenabilidade: em torno de $2 \mathrm{E}^{-4}$ a $4 \mathrm{E}^{-5}$;

- porosidade efetiva: entre 0 e $15 \%$;

- gradiente regional médio: $6 \mathrm{~m} / \mathrm{km}$, podendo atingir até $30 \mathrm{~m} / \mathrm{km}$;

- pH: varia de 5,4 (ácido) a 10,35 (alcalino), com predomínio do alcalino;

- temperatura média: 22 a 25으 nas porções livres, aumentando com a profundidade. 
A recarga do aqüífero está associada principalmente às áreas de afloramento das formações Botucatu e Pirambóia, e também através da drenagem de zonas de fissuras dos basaltos em alguns altos estruturais situados no interior da bacia. A água infiltrada para o aqüífero apresenta um fluxo geral para Oeste, porém a maior parte do escoamento subterrâneo é drenada para os rios como escoamento básico, ainda na área de recarga (CETESB, 2004).

Segundo Rocha (2002) o Aqüífero Botucatu era praticamente desconhecido até 1969. A partir de 1970 teve um surto exploratório, principalmente em sua porção brasileira. Atualmente esse aqüífero é mais explotado nas bordas da bacia, com mais de duzentos poços, a profundidades de cem a trezentos metros, sendo que alguns poços atingem até $1.500 \mathrm{~m}$ de profundidade.

Em decorrência disso, por falta de políticas governamentais, o reservatório vêm sendo explotado de maneira desordenada. Com a persistência dessas condições, problemas de superexplotação localizada ou de contaminação a partir das bordas da bacia poderão comprometê-lo (Rocha, 2002).

O relatório da situação dos recursos hídricos no Estado de São Paulo (CCPERH, 1999) classifica o eixo Botucatu - São Carlos - Ribeirão Preto como de alta vulnerabilidade, numa escala de seis níveis este eixo ocupa o segundo nível mais crítico, se forem considerados os critérios estabelecidos por Foster e Hirata (1993), que são baseados em relações entre a caracterização geológica (litológica) do aqüífero e a carga poluidora.

Segundo CETESB (1997), o município de São Carlos, situado na região centro oeste do estado, apresenta $72 \%$ de sua área no afloramento do Aqüífero Botucatu.

Segundo Freitas (1996), o Aqüífero Botucatu ocorre em todo o município de São Carlos, tendo sua principal área de recarga na porção sul da cidade, na qual ocorre livre e onde está inserida a área de estudo, o antigo lixão da cidade. Na porção norte encontra-se confinado sob os basaltos.

A cidade de São Carlos retira, para mais da metade de seu abastecimento, as águas desse manancial, o restante provém de cursos superficiais, como o Ribeirão do Feijão, o Córrego Santa Maria do Leme e o Córrego São J osé (Gonçalves et al., 1992).

Segundo Menezes, et al. (1995), o aqüífero Botucatu apresenta, na região da área de estudo, temperatura em torno de 22,1 으, $\mathrm{pH}$ de 5,1 e permeabilidade da ordem de $10^{-6}$ a $10^{-8} \mathrm{~m} / \mathrm{s}$ (Gonçalves, 1986). 


\subsection{Geologia}

A região de São Carlos situa-se no contexto geológico da Bacia do Paraná, que segundo Milani et al. (1994) desenvolveu-se sobre crosta continental, em uma sinéclise intracratônica e foi preenchida por rochas sedimentares vulcânicas. Apresenta um formato de elipse com maior eixo na direção NE-SW e recobre uma superfície de aproximadamente $1.200 .000 \mathrm{~km}^{2}$, estendendo-se pelo Brasil, Paraguai, Uruguai e Argentina, chegando a atingir $8.000 \mathrm{~m}$ de espessura.

Na borda leste da bacia, na região de São Carlos, afloram os grupos São Bento (formações Pirambóia, Botucatu e Serra Geral) e Baurú, como pode ser observado na Figura 16.

\section{a) Grupo São Bento}

Estratigraficamente, o Grupo São Bento encontra-se acima do Grupo Passa Dois e seus sedimentos são considerados como do Triássico médio ao Cretáceo inferior (Milani e Ramos, 1998).

As duas unidades da porção inferior, formações Pirambóia e Botucatu, constituem-se de sedimentos continentais predominantemente arenosos, enquanto que a porção superior do Grupo é representada por rochas basálticas da Formação Serra Geral. Incluem-se ainda, no Grupo São Bento, as soleiras e diques de diabásio, bastante freqüentes, correlatas à Formação Serra Geral, na área da Depressão Periférica Paulista. 


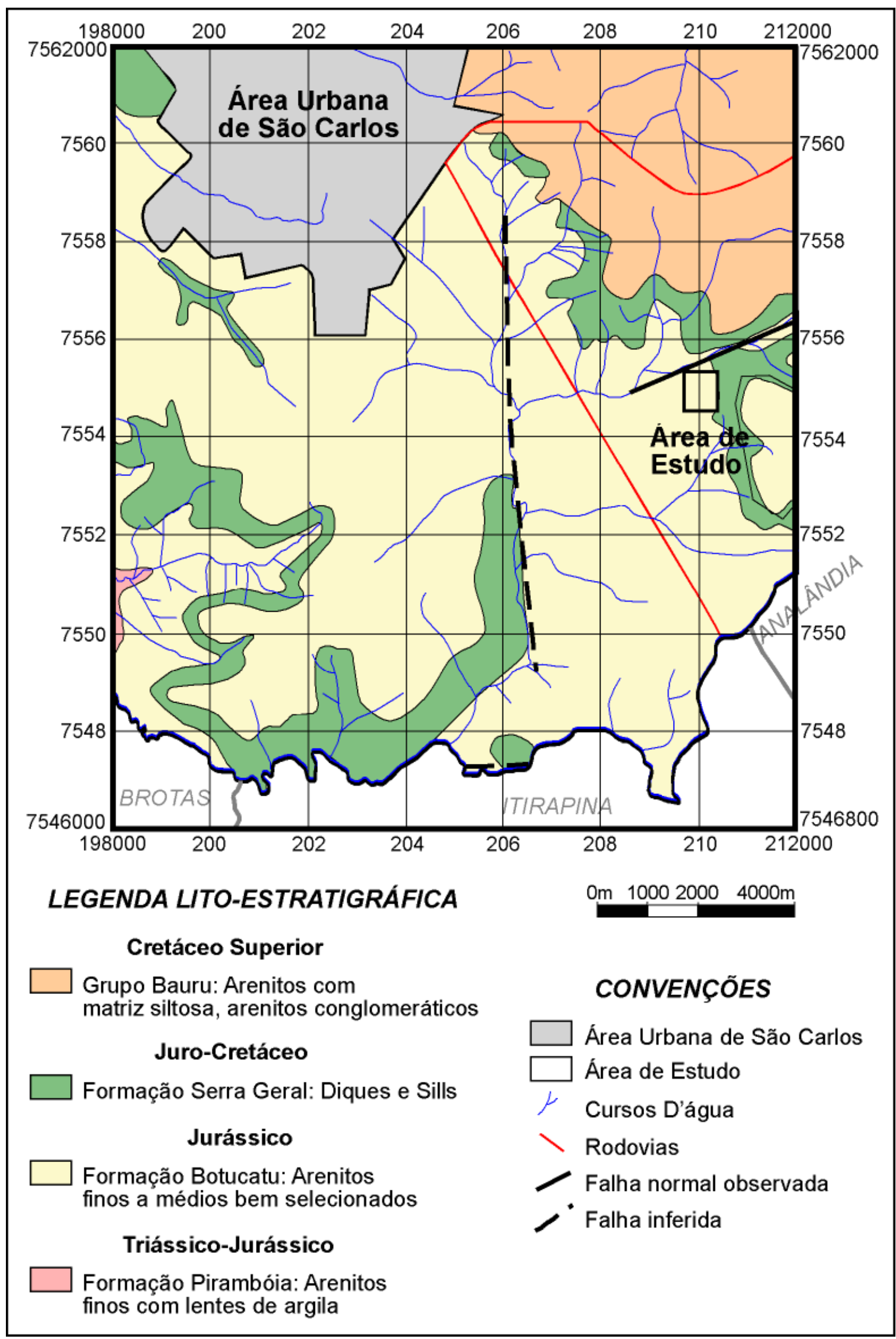

Figura 16: Mapa Geológico da região da área de estudo (modificado de Muro, 2000). 


\section{$\checkmark$ Formação Pirambóia}

A Formação Pirambóia é constituída pela parte inferior da seqüência sedimentar Mesozóica, de origem fluvio-lacustre, caracterizada por arenitos esbranquiçados amarelados, avermelhados e róseos, de granulação muito fina a média, muito a pouco argilosos; intercalando finas camadas de lamitos argilosos, exibindo estratificação cruzada planar, acanalada e plano-paralela que representam uma progressiva continentalização da bacia Milani et al. (1994).

Foi depositada em ambiente continental úmido, oxidante, geralmente fluvial, em canais meandrantes e planícies de inundação, com pequenas lagoas esparsas (IPT, 1981 apud Freitas, 1996).

Soares (1973) dividiu esta formação em dois membros; o inferior mais argiloso, com estratificações de pequeno porte; e o superior, caracterizado pela sucessão de bancos de arenitos pouco argilosos, com estratificação cruzada e bancos de arenitos mais argilosos com estratificação plano-paralela.

O contato com a Formação Botucatu é dado por uma superfície de brusca mudança textural, de estrutura e cor, definido por uma superfície regional como uma notável inconformidade, havendo um hiato deposicional de cerca de $90 \mathrm{Ma}$ entre as duas unidades (Milani, 1997).

\section{$\checkmark$ Formação Botucatu}

A Formação Botucatu, sobrejacente aos sedimentos subaquosos da Formação Pirambóia, engloba quartzo-arenitos e subarcóseos, com grau de seleção bom a muito bom e maturidade textural variando de maturo a supermaturo. Localmente podem ocorrer arenitos argilosos, mas sempre com uma porcentagem de material sílticoargiloso inferior a 5\%, e estratos lenticulares grossos (conglomerados e arenitos conglomeráticos), depositados por correntes torrenciais efêmeras e arenitos grossos, interpretados como lençóis de areia, na base (Caetano-Chang e Wu, 1993).

A presença de magnetita e ilmenita pode ser devido à contribuição do magmatismo juro-cretácico na deposição da unidade. Nas partes mais profundas da unidade a calcita e a dolomita são os cimentos mais abundantes (Caetano-Chang e Wu, 1993).

Apresenta estratificações cruzadas de grande porte, caracterizando uma gênese de origem eólica em ambiente desértico. Apresenta estratificações cruzadas de porte médio a grande, com inclinação em torno de 30o e espessura máxima em torno de 130 m, raramente ultrapassando os 100 m. (IPT, 1981 apud Freitas, 1996).

Esta formação é limitada na base por uma inconformidade regional que se estende por toda a bacia, gerando uma vasta superfície de deflação eólica 
estabelecida com o climax de aridez do Gondwana ocidental (Milani, 1997), e é sobreposto por rocha vulcânicas básicas e ácidas da Formação Serra Geral.

Os materiais da Formação Botucatu, bem como os da Formação Pirambóia, são derivados de áreas de relevo pouco acentuado, advindos de rochas cristalinas e sedimentares preexistentes, depositados em bacia estável, com transporte relativamente prolongado e fortemente retrabalhados por abrasão seletiva em clima semi-árido e árido de ambiente desértico, eventual e temporariamente cortado por rios (Milani, 1997).

$\mathrm{Na}$ área de estudo essa formação é representada por um pacote homogêneo de arenitos avermelhados a amarelados (Figura 17), com granulação variando de areia média a grossa e muito fina a fina, predominando fina a média, com grãos arredondados a bem arredondados na fração grossa e subangulares a arredondados na fração fina, alta esfericidade e foscos, muito friáveis ou silicificados.

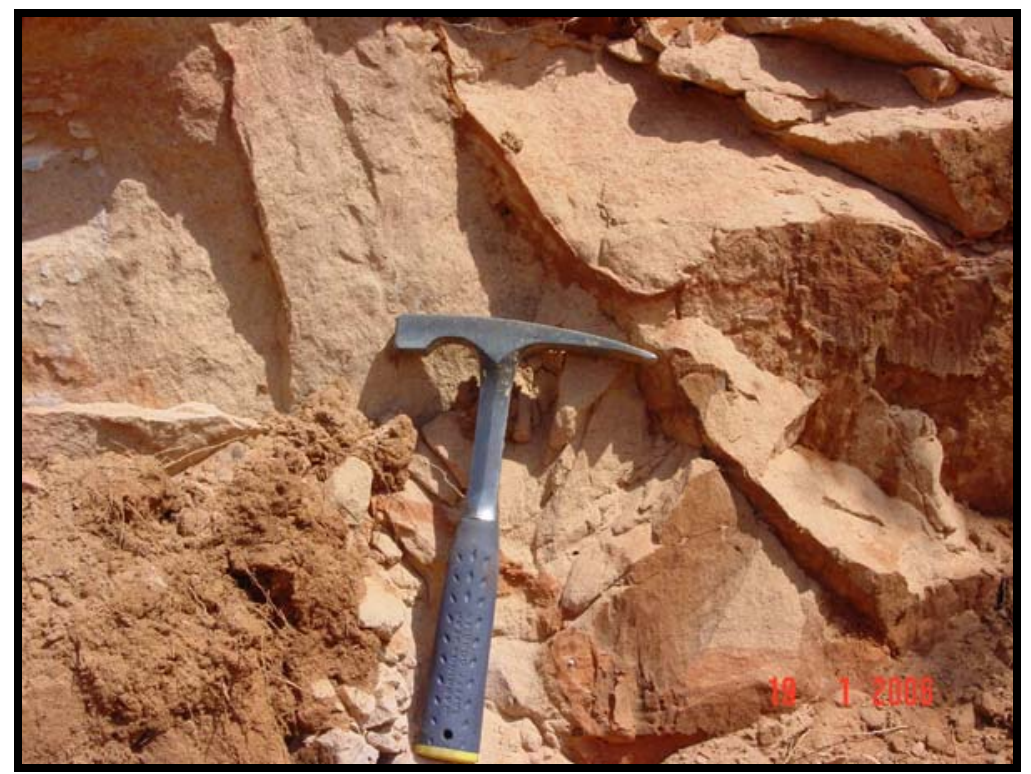

Figura 17: Arenito da Formação Botucatu presente na área de estudo.

\section{$\checkmark$ Formação Serra Geral}

A Formação Serra Geral é constituída por rochas vulcânicas de caráter básico com extensa distribuição em toda área da Bacia do Paraná tanto na forma de derrame como em corpos intrusivos (Pfeiffer, 1993).

O magmatismo mesozóico da Bacia do Paraná apresenta características regionais relacionadas a anomalias químicas, indicando uma pluralidade de fontes e mecanismos na formação do magma. O derrame vulcânico continental é composto em mais de $90 \%$ do volume por basaltos toleíticos e andesito basáltico, geralmente exibindo vesículas e amígdalas no topo do derrame (Milani, 1997).

Os basaltos são toleíticos e apresentam espessura individual bastante variável, desde poucos metros a mais de $50 \mathrm{~m}$ e extensão individual que pode ultrapassar dez 
quilômetros. Nesses basaltos ocorre a intercalação de arenitos com as mesmas características dos arenitos da Formação Botucatu, a maioria com estruturas típicas de dunas e outros indicando deposição subaquosa (Milani, 1997).

Os diabásios são em geral de granulação fina, cinza escuro a negros, maciços, no qual se destacam ripas de plagioclásio (Milani, 1997).

A espessura máxima da Formação Serra Geral foi medida em sondagem em Cuiabá Paulista (Pontal do Paranapanema, Estado de São Paulo), indicando $1.700 \mathrm{~m}$ de derrames (Almeida, 1986). Tal pacote adelgaça-se para as bordas do Planalto Ocidental, onde as serras basálticas possivelmente não alcançam um terço desse valor (IPT 1981).

Segundo Zuquette (1981) apud Menezes (1995), a espessura dessa formação na região é em torno de $165 \mathrm{~m}$.

A Formação Serra Geral ocorre próximo a área de estudo, aproximando-se do topo das cristas (acima de $875 \mathrm{~m}$ ), onde ocorre de forma bastante alterada, sendo comum encontrar-se apenas o solo residual.

Para cobertura do lixão desativado de São Carlos foi utilizado principalmente o solo residual dessa formação.

\section{b) Grupo Bauru}

Cessados os derrames de lavas da Formação Serra Geral, que marcaram o final dos eventos deposicionais e vulcânicos generalizados na área da Bacia do Paraná, observou-se uma tendência geral para o soerguimento epirogênico em toda a Plataforma Sul-Americana em território brasileiro (Milani, 1997).

A porção norte da Bacia do Paraná, entretanto, comportou-se como área negativa relativamente aos soerguimentos marginais e à zona central da bacia, marcando o início de uma fase de embaciamentos localizados em relação à área da bacia como um todo, nessa área deprimida acumulou-se o Grupo Bauru (Milani, 1997).

O grupo Bauru corresponde, portanto as coberturas pós-lavas que foram acumuladas na depressão flexural ocorrida devido ao peso dos derrames da Formação Serra Geral, (Milani et al. 1994) e é composto pelas formações Uberaba, Vale do Rio do Peixe, Araçatuba, São J osé do Rio Preto, Presidente Prudente e Marília, inclui ainda os Analcimitos Taiúva, rochas vulcânicas localmente intercaladas na seqüência (Fernandes, 2004).

$\mathrm{Na}$ região próxima a área estudada o Grupo Bauru é representado por sedimentos arenosos-conglomeráticos que apresentam clastos de variadas litologias, como vulcânicas, arenitos, rochas do embasamento etc. 


\subsection{Histórico e trabalhos anteriores}

Os resíduos coletados no município de São Carlos foram depositados nesse local inadequado, onde estava instalada uma voçoroca de grandes dimensões, por aproximadamente 17 anos, totalizando um volume de resíduos de aproximadamente $440.000 \mathrm{~m}^{3}$. Segundo Zuquette e Gandolfi (1991) essa área apresenta muitas características desfavoráveis para o uso a qual foi destinada, ressaltando:

- A profundidade do nível da água subterrânea, máxima de 8,7 m e mínima de 1,97 m;

- A litologia da área, constituída por arenitos permeáveis com poucos finos;

- Os materiais inconsolidados predominantemente arenosos;

- A alta permeabilidade dos arenitos, em torno de $10^{-4} \mathrm{~cm} / \mathrm{s}$;

- O baixo coeficiente de troca catiônica do substrato do lixão, de 2,71 a 2,73 meq/100g;

- O alto potencial a erosão.

As atividades de depósito, que incluíam desde resíduos domiciliares, de serviços de saúde até industriais, iniciaram-se aproximadamente em 1979, foram interrompidas em junho de 1994, reiniciaram-se em fevereiro de 1995 e se encerraram finalmente em junho de 1996.

De acordo com estudos realizados por Gomes (1991) em 1988, a cidade de São Carlos produzia cerca de 2.200 toneladas de lixo/mês, o que representava uma produção de cerca de 470 gramas/habitante/dia, aproximadamente. De acordo com a caracterização dos resíduos sólidos foram gerados cerca de 56,7\% de matéria orgânica; $21,3 \%$ de papéis; $8,5 \%$ de plásticos; $5,4 \%$ de metais e $1,1 \%$ de vidro, sobre o total gerado durante o período de um mês.

De acordo com a Secretaria de Desenvolvimento Sustentável, Ciência e Tecnologia do Município de São Carlos esse lixão encerrou suas atividades e agora mantém uma situação "controlada", pois recebe monitoramento da CETESB a cada seis meses.

Embora exista um "Plano de Recuperação e Conservação do Antigo Lixão de São Carlos Sitio Santa Madalena, SP" e de alguns dos itens nele propostos terem sido realizados, o passivo ambiental está instalado, possibilitando a contaminação do solo e do lençol freático subjacentes.

A área atualmente é ocupada por atividades rurais como criação de gado leiteiro e plantação industrial de goiabas, como pode ser observado na foto da Figura 18. 


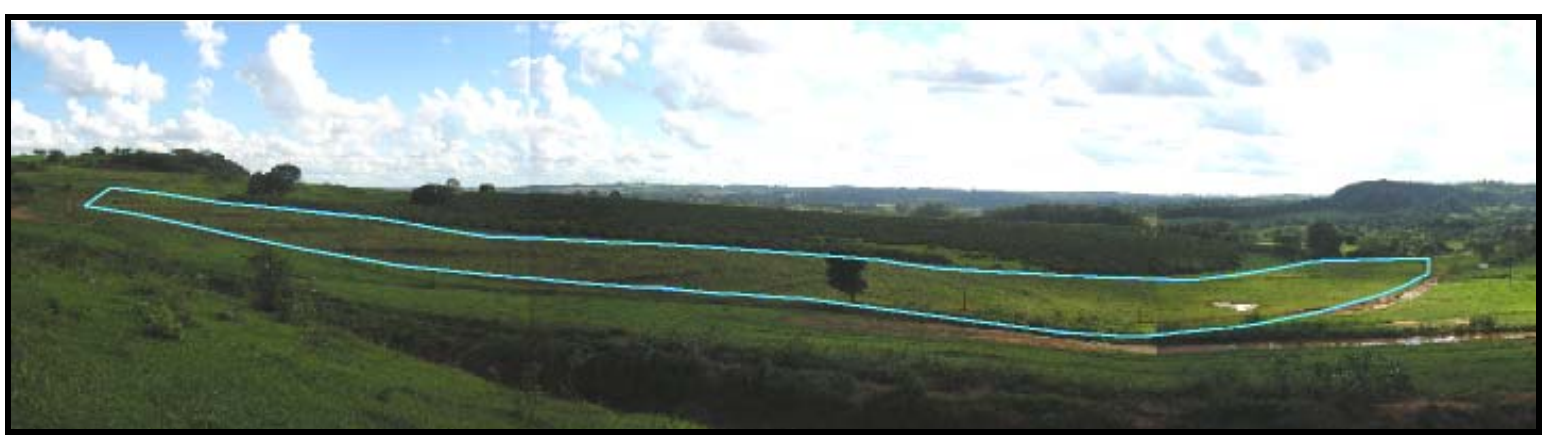

Figura 18: Vista atual da área de estudo, a linha azul indica a antiga cava de resíduos.

Estudos anteriores já revelaram que existe contaminação e poluição da água subterrânea no local, situação preocupante, já que a área situa-se em zona de recarga do Aqüífero Guarani e faz parte da Bacia Hidrográfica do Ribeirão do Feijão, principal fonte de abastecimento de água da cidade.

Dentre os trabalhos já realizados anteriormente na área, pode-se citar:

- Ellert et al. (1990) realizaram levantamentos geofísicos no lixão de São Carlos, com o emprego de eletrorresistividade e de eletromagnetometria indutiva, determinaram a pluma de poluentes e o comportamento vertical e horizontal da geologia local. Como resultados obtiveram a direção da pluma de contaminante para WNW e a detecção de zonas silicificadas em subsuperfície. Durante a execução desse trabalho, 3/4 da extensão da vala (voçoroca) do lixão já estavam preenchidos, com difícil definição dos limites laterais.

- Nishiyama e Zuquette (1991) em um estudo preliminar para elaboração de uma carta de deposição de rejeitos sépticos da região de São Carlos, classificaram a área onde se encontra o lixão de Santa Madalena, bem como a maior porção do município, como inadequado, por encontrar-se sobre área de recarga do aqüífero Botucatu, além de ouros fatores analisados, como declividade, erodibilidade e permeabilidade.

- Gonçalves et al. (1992) com a instalação de 10 poços piezométricos determinaram a direção do fluxo do lençol freático para direção NW, a direção do fluxo e a alta permeabilidade do solo no local indicam que grande parte do chorume deve estar infiltrando para o aqüífero profundo.

- Schalch (1992) análisou percolados de dois aterros experimentais, construídos na região do lixão de São Carlos e com o mesmo lixo a ele destinado, encontrou altas concentrações de metais pesados.

- Bossolan (1993) realizou estudos sobre a contaminação da água subterrânea do local, enfocando aspectos bacteriológicos e químicos definiu a direção do fluxo subterrâneo a partir de linhas isopiezométricas e 
verificou a direção NW como predominante. Observaram-se valores de $\mathrm{pH}$, oxigênio dissolvido e de alguns metais ( $\mathrm{Ca}, \mathrm{Mg}, \mathrm{Fe}$ ), indicando forte influência do líquido percolado sobre a água subterrânea, os indicadores bacteriológicos de poluição fecal, analisados na água subterrânea, estavam acima dos limites, embora a autora ressalte que o lixão pode não ser a única fonte de poluição do recurso hídrico, pois as bactérias encontradas podem ser provenientes da matéria orgânica gerada por pastagens de gado próximas ao local.

- Menezes (1995) levantou diversos dados de contaminação de poços e encontrou valores de condutividade, nas amostras de água coletadas, muito acima do aceitável para a área atingida pela pluma, além desses valores terem aumentado em relação a dados coletados anteriormente por Bossolan (1993).

- Freitas (1996) evidenciou, de levantamentos geológicos e geofísicos, heterogeneidades (transmissividade) e anisotropia (condutividade hidráulica) no aqüífero, também determinou a direção de fluxo do aqüífero para WNW a partir de linhas equipotenciais.

- Gadotti (1997) estudou a contaminação das águas superficiais e subterrâneas adjacentes ao lixão da cidade de São Carlos-SP e concluiu que existe um escoamento na direção SW, pelo mapa do escoamento subterrâneo apresentado pelo autor é perceptível a presença de duas direções principais de escoamento, uma obedecendo à direção da drenagem superficial, NW, e outra em direção WSW. Detectou ainda altas concentrações de nitrato, bário e cloreto, que ultrapassaram os limites de potabilidade nas águas superficiais e subterrâneas ao redor do aterro.

- Contin Neto et al. (1997) obteve resultados de modelagem matemática que indicam o fluxo de água subterrânea que carreia o soluto com sentido NENW. Extrapolando os dados obtidos, encontraram valores de velocidade para a pluma que em 100 anos andaria aproximadamente 1000 m, respeitando-se as condições de contorno atuais.

- Matsuzaki (1998) realizou uma simulação computacional da trajetória da pluma no aqüífero, com dados da geologia, da hidrografia e da pluviometria local, demonstrando o deslocamento preponderante da frente da pluma em direção SW, caminhando para um reservatório de água do córrego São José e alguns poços das proximidades.

- Fusconi e Godinho (1999) estudaram aspectos ecológicos dos microorganismos das águas subterrâneas do local e encontraram a 
influência do chorume proveniente do aterro nas populações microbianas analisadas.

- Álvares (2000) realizou estudos geológicos, geofísicos, topográficos e químicos, para o conhecimento do meio físico da região e indicou a existência de transporte superficial advectivo de contaminantes muito superior ao de sub-superfície, identificando a presença de superfícies resistivas que supostamente protegem o aqüífero profundo, indicou o movimento da pluma seguindo a topografia do terreno, portanto, NW.

- Penner, et al. (2003) simularam, pelo método dos elementos analíticos, três técnicas de controle hidráulico para contenção do avanço da possível pluma de contaminação. Por se tratar de um método computacional não convencional, utilizaram a alternativa de poço de captura para uma comparação com uma outra simulação já empregada à contenção da pluma do lixão encontrando bons resultados. A partir daí, a simulação da alternativa de dreno horizontal conseguiu a captura aspirada com a menor vazão de bombeamento. A aplicação do dipolo, apesar de trazer em geral um bom isolamento da pluma, não teve um bom ajuste aos contornos da região. 


\section{Procedimentos e Resultados}

\subsection{Ensaios geofísicos}

Foram realizadas seis linhas de caminhamento elétrico dipolo-dipolo conjuntamente com caminhamento IP domínio tempo, produzindo perfis de resistividade e de cargabilidade.

\subsubsection{Locação das linhas}

Um dos parâmetros utilizados para locar as linhas de caminhamento desse trabalho foi o de passar por alguns dos poços de monitoramento já instalados e ainda existentes, permitindo uma "aferição" da profundidade de investigação geofísica á partir das leituras de nível d'água. A localização desses poços foi realizada por Álvares (2000) com GPS de precisão e esses dados podem ser visualizados no Anexo I.

Outro parâmetro utilizado para locar as linhas foi o de que pelo menos algumas linhas coincidissem com as anteriormente realizadas por Freitas (1996), para permitir uma comparação no tempo, avaliando a evolução da pluma de contaminantes. Três linhas coincidem, quase que perfeitamente, com esses caminhamentos, como pode ser observado na Figura 19.

As linhas geofísicas foram dispostas na direção NE-SW, de maneira a abranger as áreas dos resíduos e parte das áreas adjacentes. Foram posicionadas perpendiculares ao corpo do lixo e à possível direção preferencial do fluxo subterrâneo, igual ao superficial, como sugerido por Ellert et al. (1990), Gonçalves et al. (1992), Bossolan (1993), Freitas (1996), Gadoti (1997) e Álvares (2000).

Também foram dispostas linhas a jusante do corpo do lixo (linhas 0 e 1), para permitir um estudo de como a possível contaminação se comporta e afeta essas porções (Figura 19). 


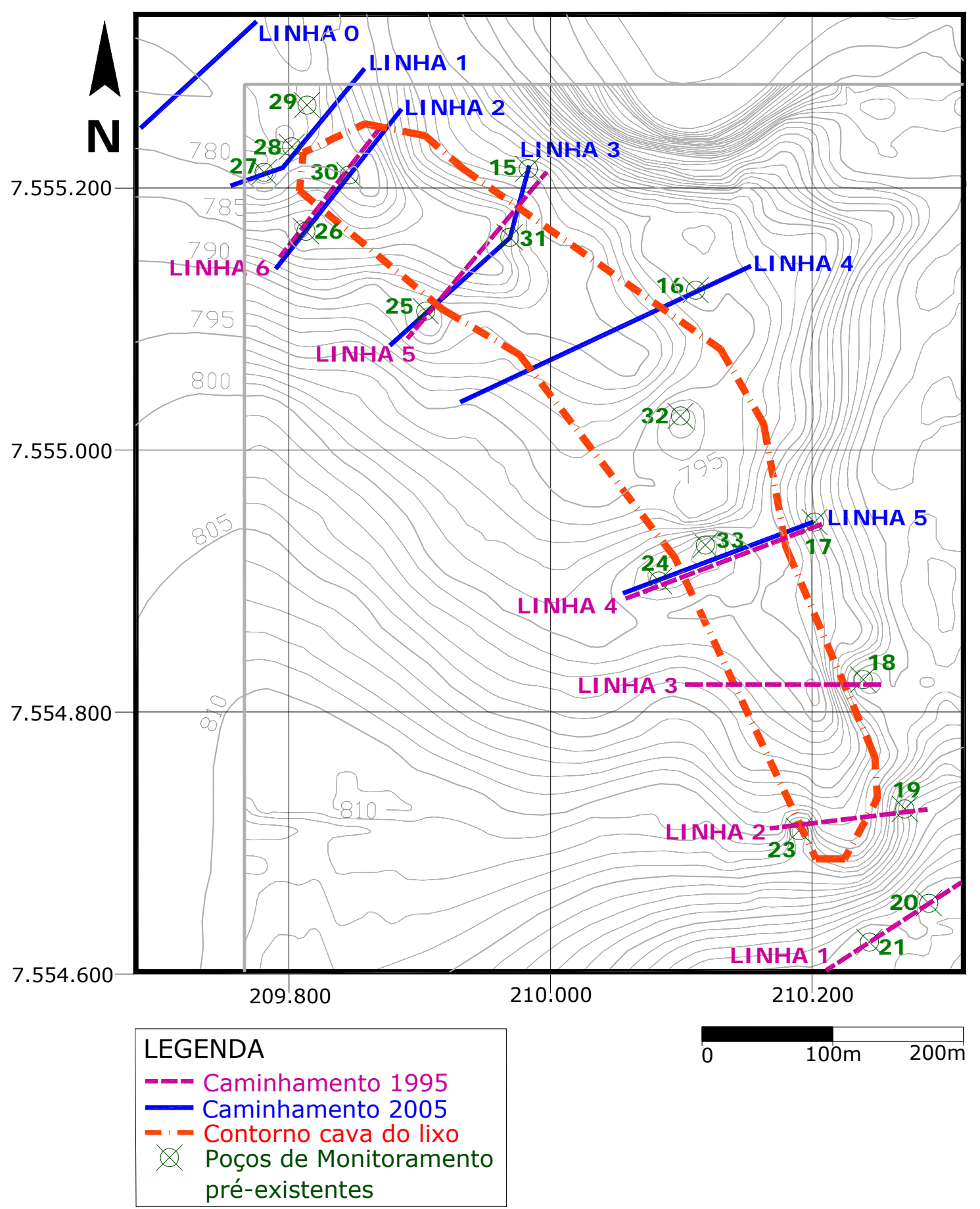

Figura 19: Mapa com localização dos poços, linhas de caminhamento elétrico e contorno da cava de depósito dos resíduos. Topografia baseada nos mapas IGC folhas SF-23-Y-A-I-1-NE-(C, D, E e F) de escala 1:10.000 e contribuições de Álvares, 2000.

\subsubsection{Execução do ensaio}

Nesse trabalho foi utilizado o método da eletrorresisitividade, simultaneamente com o de polarização induzida (IP), com a utilização do equipamento Iris Syscal R2 (Figura 20). 


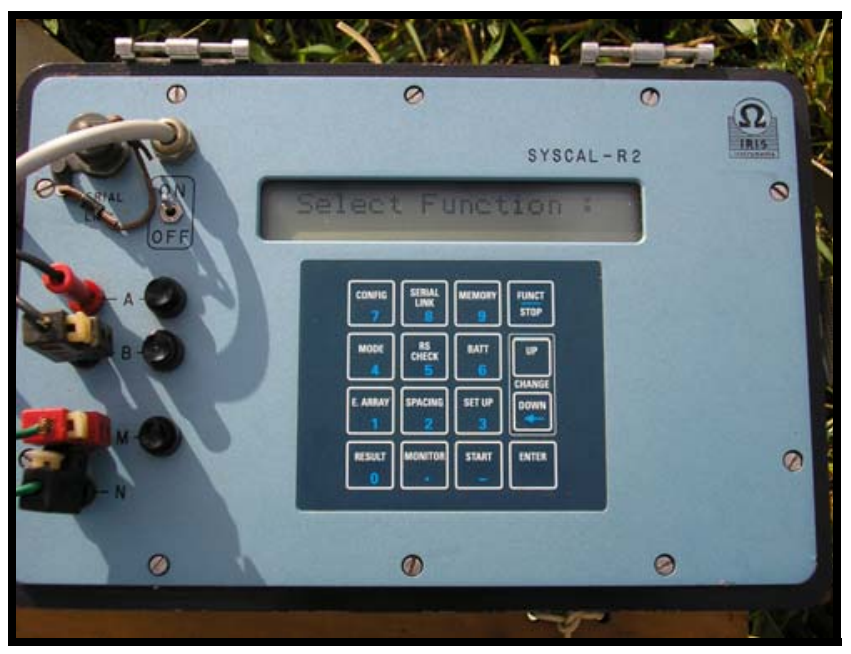

Figura 20: Equipamento Iris Syscal R2 utilizado no ensaio de resistividade e cargabilidade.

O ensaio de campo consistiu na introdução de uma corrente elétrica artificial através de dois eletrodos ( $\mathrm{A}$ e $\mathrm{B}$ ), com o objetivo de medir o potencial gerado em outros dois eletrodos ( $\mathrm{M}$ e $\mathrm{N}$ ), permitindo a determinação da resistividade aparente em subsuperfície, avaliando-se a variação vertical.

Nesse arranjo os eletrodos são dispostos em um mesmo perfil, contínuo, sendo que o arranjo é definido pelo espaçamento $X=A B=M N$ (Figura 21). Neste trabalho o espaçamento adotado entre dipolos foi de 10 metros $(X=A B=M N=10 \mathrm{~m})$.

A profundidade investigada varia conforme o espaçamento $R$, que é a distância do centro de $A-B$ até o centro de $M-N$ (Figura 21), quanto maior $R$, maior a profundidade a ser investigada, sendo que cada dipolo $\mathrm{M}-\mathrm{N}$ se refere a um nível de investigação. Nesse estudo investigaram-se 5 níveis, atingindo uma profundidade teórica de 30 metros no nível 5.

As medidas usualmente são efetuadas em profundidades distintas, em níveis, sendo que os pontos são plotados nas intersecções das linhas que partem do centro de A-B e do centro de $M-N$, com ângulos de $45^{\circ}$ (Figura 21).

A partir desses pontos faz-se uma interpolação, gerando assim, as seções de resistividade aparente. Essas seções são interpretadas de maneira a delimitar zonas com diferentes resistividades, que podem ser relacionadas com o estado real do terreno, como nível d'água, profundidade e sentido da pluma de contaminantes, entre outros. 


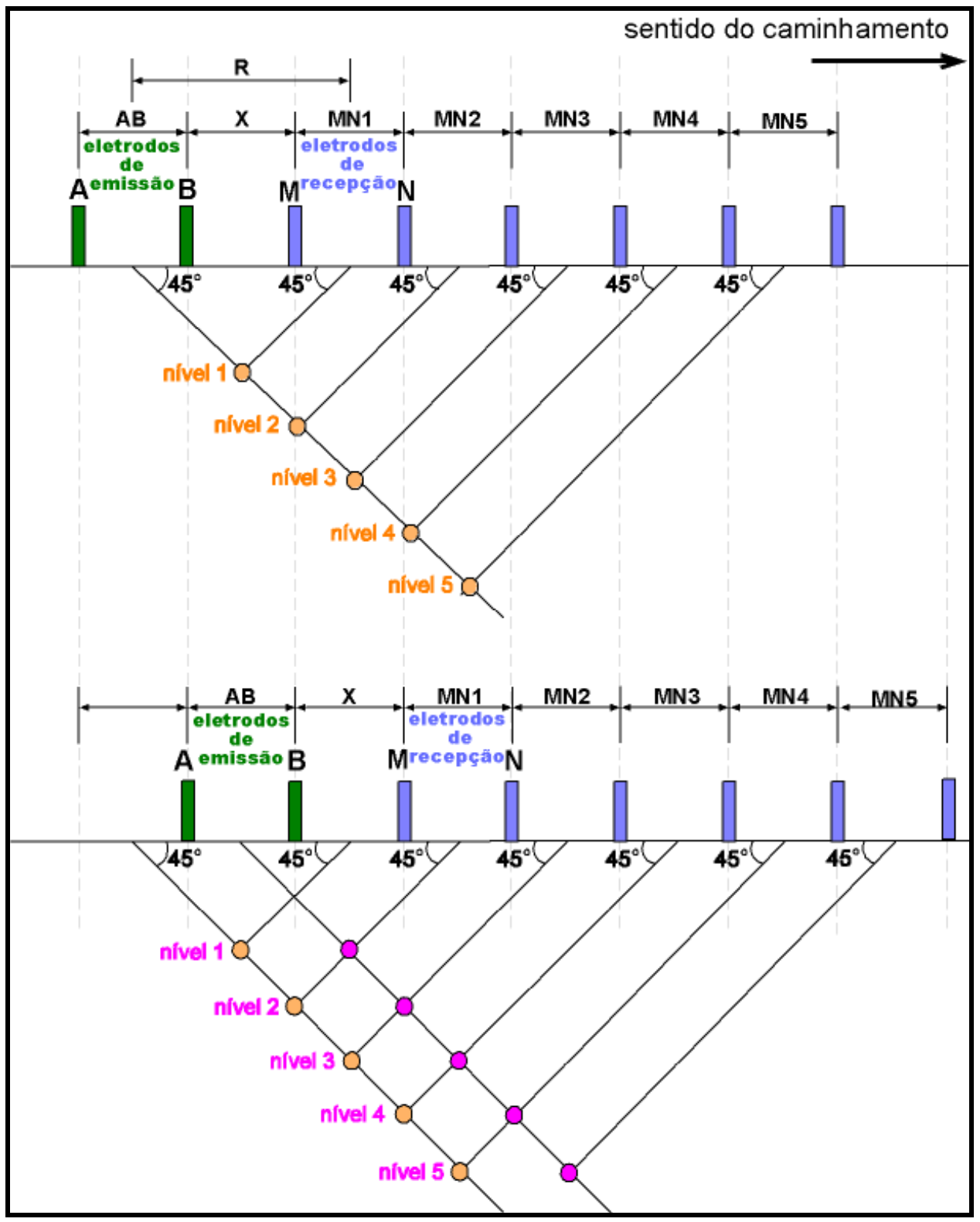

Figura 21: Representação esquemática do caminhamento elétrico executado.

Outro método de medida utilizado nesse estudo, conjuntamente com o de caminhamento elétrico, foi o de polarização induzida no domínio tempo, que segundo Sumner (1976) apud Elis (1998), consiste em um fenômeno elétrico estimulado por corrente, observando-se como reposta retardada a voltagem.

Esse efeito resultante da passagem de corrente elétrica gera um campo elétrico, que mesmo depois de cessada a corrente não desaparece imediatamente, mas de um modo lento, o que caracteriza a polarização induzida ou residual.

Durante o tempo do fluxo original de corrente ocorre armazenamento de várias formas de energia nos materias, sendo que a energia química, segundo Elis (1998), é a mais importante e resulta da variação da mobilidade de íons fluindo através da 
estrutura dos materiais e da variação entre a condutividade iônica e eletrônica, onde minerais metálicos estão presentes.

A resposta da polarização induzida é medida como uma variação de voltagem em função do tempo ou da freqüência, sendo denominados, respectivamente, IPDomínio do Tempo e IP-Domínio da Freqüência. Nesse estudo utilizou-se o IP-Domínio do Tempo, no qual o parâmetro cargabilidade é obtido com a integração da curva de descarga durante um intervalo de tempo.

Segundo Elis (1998) alguns casos de aplicação de caminhamento IP e resistividade são apresentados por Vogelsang (1995) e mostram que a polarização induzida pode apresentar mais detalhes sobre o tipo de resíduos enterrados, baseado nos materiais eletricamente polarizáveis, mas, ainda não são conhecidos satisfatoriamente os materiais que apresentam altas cargabilidades.

No entanto os estudos de Vogelsang (1995) apud Elis (1998) indicam que os valores anômalos de cargabilidade dos resíduos enterrados são geralmente muito altos, e que usualmente refletem sua heterogeneidade.

\subsubsection{Tratamento dos dados}

Os dados geofísicos obtidos nesse trabalho foram tratados em dois programas, o Surfer 8.0, que é um programa para interpolação, e o RES2DINV 3.2, que é um programa próprio para inversão da resistividade e polarização induzida (IP).

A interpretação inicial fez-se a partir das seções de resistividade aparente geradas no Surfer 8.0, mas como o parâmetro resistividade aparente representa uma resultante de um volume do subsolo investigado constituído de diferentes resistividades, sentiu-se a necessidade de trabalhar com a resistividade mais próxima da real.

Para tanto tornou-se necessária a aplicação de processos de inversão, que buscam estabelecer um modelo da provável distribuição real dos valores de resistividade em subsuperfície, sendo que eventuais distorções nas pseudoseções são teoricamente eliminadas por este procedimento.

Então as seções foram modeladas no RES2DINV, que utiliza um processo automático de inversão bi-dimensional (2-D), com a técnica de otimização dos mínimos quadrados com suavização não linear (Loke e Barker, 1996).

$\mathrm{Na}$ interpretação pelo RES2DINV houve a possibilidade de plotar os dados juntamente com a topografia, permitindo melhor análise dos dados obtidos. Contudo, uma desvantagem desse programa foi a impossibilidade de alterar os valores da escala de cores, portanto a escala de cores corresponde a valores diferentes em cada 
seção, dificultando a comparação, que deve ser feita analisando diretamente os valores.

Para que pudesse ser feito o estudo comparativo dos dados de caminhamento elétrico realizados em diferentes datas, de forma a representar a evolução da contaminação na área, optou-se por tratar novamente os dados coletados por Freitas (1996), da mesma forma e nos mesmos programas utilizados para os dados dos caminhamentos atuais.

Para permitir uma relação da geofísica com os dados litológicos e de campo foram confeccionados perfis topográficos das linhas de caminhamento. Esses perfis foram baseados nos dados obtidos por Freitas (1996) quando executou os poços de monitoramento na área e nos dados gerados por Álvares (2000) a partir de perfilagens geofísicas associados a perfis geológicos, esses dados foram então comparados com os dados obtidos em campo nesta pesquisa.

Para aferir os perfis geofísicos foram medidas as profundidades dos níveis de água (NA) em cada um dos poços de monitoramento após a realização dos ensaios de caminhamento, correlacionando essas profundidades as anomalias encontradas na geofísica, ajustando desta forma, o NA das anomalias geofísicas com o NA verdadeiro observado em campo.

\subsubsection{Resultados da Geofísica}

Os resultados dos ensaios geofísicos são apresentados no Anexo II na forma de seções de resistividade e cargabilidade, geradas ao longo de cada linha de caminhamento elétrico executada.

São apresentados também, para efeito de comparação, as seções com os dados de Freitas (1996), reinterpretados nos mesmos programas utilizados neste trabalho (Surfer 8.0 e RES2DINV). A análise e discussão destes resultados serão realizadas no Capítulo 5.

\subsection{Ensaios de infiltração}

Foram realizados 5 ensaios de infiltração in situ visando caracterizar os materiais inconsolidados quanto as suas propriedades hidráulicas.

Segundo Jorge e Uehara (1998), a capacidade de infiltração corresponde ao máximo de água que pode ser absorvida pelo solo. Normalmente, quando a água começa a entrar no solo, apresenta taxas de infiltração altas, que progressivamente vão diminuindo até atingir um comportamento constante de infiltração. 


\subsubsection{Locação dos pontos ensaiados}

Os cinco ensaios foram locados de maneira que pelo menos dois ensaios fossem realizados sobre o corpo do lixo ( $U$ e $V$ ), e os demais $(R, S, T)$ distribuídos em diferentes pontos, mas que estivessem distantes do NA, para que tornasse possível a caracterização de maior profundidade do subsolo não saturado. A localização dos pontos de ensaio pode ser observada na Figura 22.

Os ensaios realizados sobre o corpo do lixo ( $U$ e $V$ ) tiveram como objetivo avaliar as características de infiltração da camada de cobertura do lixo.

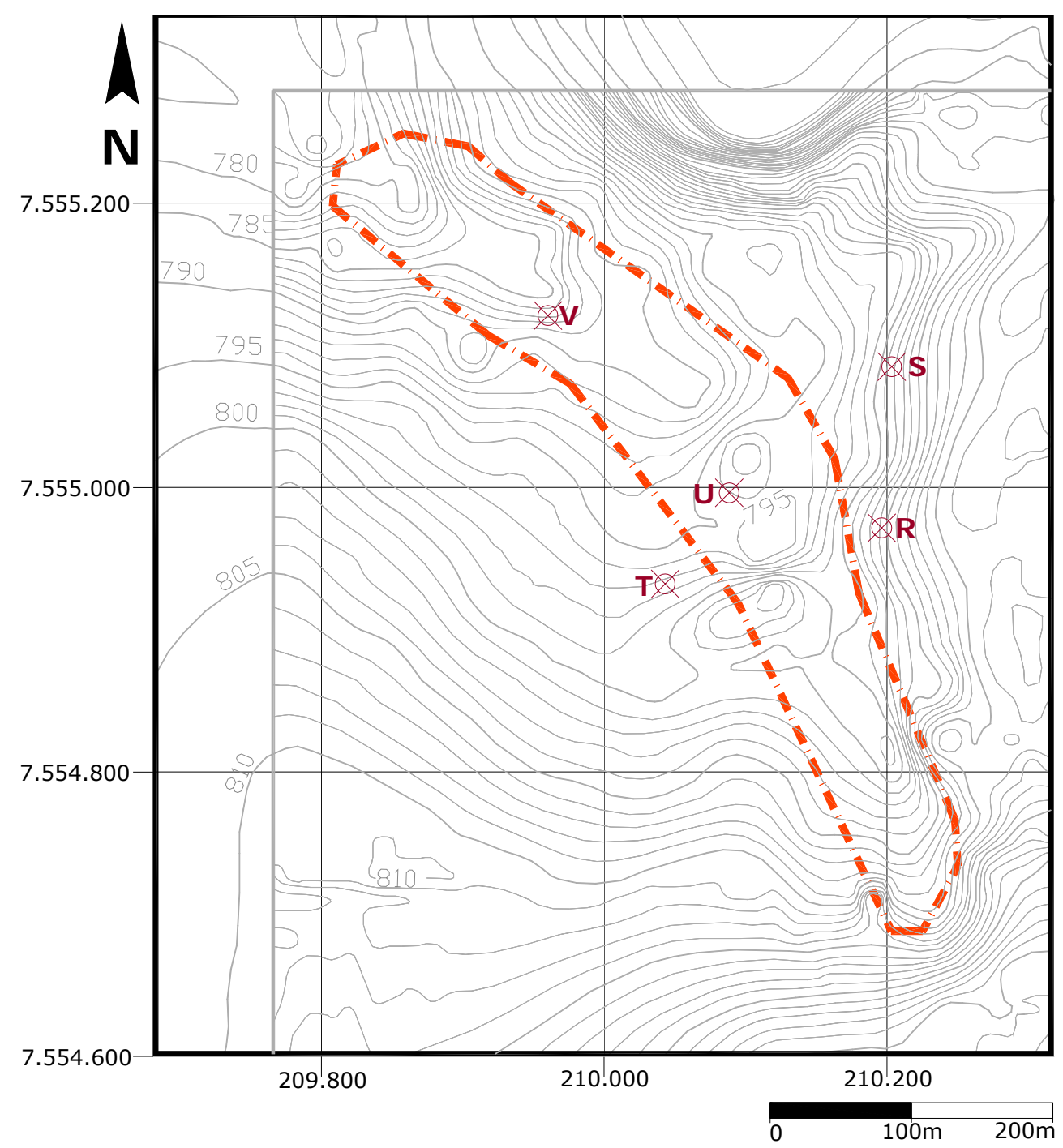

Figura 22: Localização dos pontos onde foram realizados os ensaios de infiltração.

\subsubsection{Execução}

No ensaio de infiltração foi utilizado o infiltrômetro do duplo anel (IAD), normalizado pela ASTM-D 3385-88 (1988) que constitui uma ferramenta importante para determinação do comportamento hidráulico dos materiais de subsuperfície. 
O IAD consiste em dois cilindros de chapas de aço de $3 \mathrm{~mm}$ de espessura, sendo um com dimensões de $30 \mathrm{~cm}$ de altura por $30 \mathrm{~cm}$ de diâmetro (cilindro interno número 2 da Figura 23) e o outro com $25 \mathrm{~cm}$ de altura por $60 \mathrm{~cm}$ de diâmetro (cilindro externo - número 1 da Figura 23). Também compõem o ensaio um balde plástico graduado (número 3 da Figura 23) e uma mangueira que une o balde até os anéis (número 4 da Figura 23), dotada de uma bóia na extremidade dos anéis, além de baldes pra encher o anel externo (número 5 da Figura 23) e de um cronômetro.

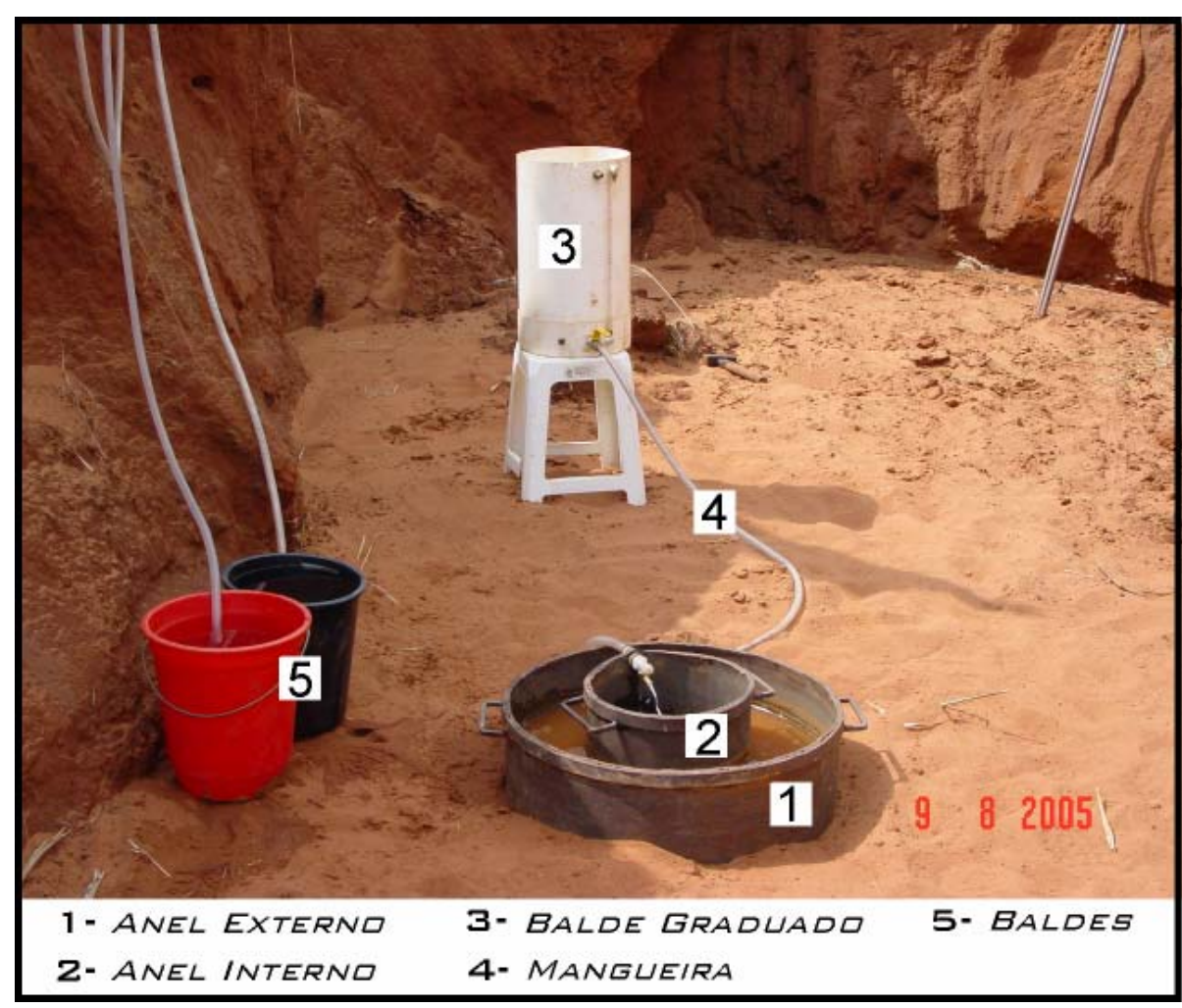

Figura 23: Montagem do ensaio de infiltração IAD in situ.

A execução do ensaio inicia-se com a cravação dos cilindros, que deve ser executada de tal maneira que não perturbe as estruturas do solo.

Após a cravação desses anéis, de forma que o anel interno fique no centro do anel externo, deve-se enchê-los com água até que o anel interno fique com lâmina d'água de aproximadamente $10 \mathrm{~cm}$ e o anel externo, com uma lâmina levemente inferior a do anel interno.

Essas alturas de lâmina d'água devem permanecer constantes. Conforme a água infiltrar no terreno, o anel interno será abastecido pela mangueira, que é dotada de uma bóia em uma de suas extremidades, de tal forma que quando o nível d'água baixa dentro do anel a bóia desce, permitindo o fluxo d'água da mangueira. Como a mangueira está conectada a um cilindro graduado, é possível que seja medida a quantidade de água infiltrada em tempos determinados. 
O anel externo deverá ser cheio manualmente com os baldes, também mantendo a sua lâmina d'água constante. Esse anel externo é importante no ensaio para que se mantenha um fluxo unidimensional no anel interno.

Assim que os anéis estiverem cheios deve-se iniciar o ensaio, realizando as leituras de água infiltrada no anel interno em tempos cronometrados.

Iniciam-se as leitura em intervalos de 1 minuto $(1,2,3,4,5,6,7,8,9$ e 10 min), passando para intervalos de 5 minutos $(15,20,25,30,35,40 \mathrm{~min}) \mathrm{e}$ posteriormente para intervalos de 10 minutos $(50,60,70,80,90,100,110,120 \mathrm{~min}$, etc), até que pelo menos 3 leituras de infiltração sejam iguais, indicando um fluxo de água constante, finalizando o ensaio.

O tempo para a execução do ensaio vai depender das condições do terreno, de tal forma que pode levar de alguns minutos até horas, quando a taxa de infiltração atinge um comportamento constante.

Nos locais escolhidos para realização desse ensaio também foram coletadas amostras deformadas, de 20 em 20 centímetros, para a obtenção da umidade natural do solo e umidade do solo saturado, indicando a profundidade que a "frente de molhamento" atingiu. Esse procedimento também auxiliou na caracterização dos materiais de subsuperfície.

Para a coleta dessas amostras foram realizados 3 furos a trado manual. O primeiro realizado antes do ensaio, a aproximadamente 2 metros de distância do local de cravação dos anéis, para caracterização da umidade natural do solo.

O segundo furo foi realizado no centro do anel interno, imediatamente após a finalização do ensaio, para caracterização da umidade do solo saturado. O terceiro furo foi realizado ao lado do segundo, após duas horas da finalização do ensaio, para caracterização da umidade do solo saturado após 2 horas.

\subsubsection{Resultados}

As planilhas com os dados obtidos nos ensaio são apresentadas no Anexo III, enquanto que as planilhas de cálculo e as curvas de infiltração no Anexo IV.

A condutividade hidráulica foi calculada através da Equação 1. 


$$
K=\frac{Q}{\frac{H+Z}{Z} \times A \times t}
$$

Onde,

K: Condutividade hidráulica;

Q: Volume de água infiltrado no solo;

$\mathrm{H}$ : Profundidade de água no anel quando ensaiado a regime constante;

Z: Profundidade da frente de saturação;

A: Área transversal do anel;

$\mathrm{t}$ : Tempo entre medidas.

Embora a infiltração se dê de maneira distinta nos diferentes materiais (solo e lixo), de modo geral, a condutividade hidráulica na área estudada é da ordem de $10^{-5} \mathrm{~m} / \mathrm{s}$, sendo que isto pode variar pontualmente, principalmente sobre o lixo, por sua falta de uniformidade.

De maneira geral quanto maior a infiltração de água em um solo, menor a possibilidade de escoamento superficial direto, conseqüentemente maior a possibilidade de ocorrer contaminação.

Também foi possível determinar a profundidade que a "frente de molhamento" atingiu em cada um dos ensaios (Figura 24), calculando as umidades de cada uma das amostras coletadas.

No ensaio " $\mathrm{T}$ " a frente de molhamento atingiu a maior profundidade, em torno de 3,6 m, no ensaio " $\mathrm{R}$ " chegou a 1,8 $\mathrm{m}$ e no ensaio " $\mathrm{S}$ " atingiu $1,0 \mathrm{~m}$.

Nos ensaios " $U$ " e " $V$ " realizados em cima do corpo do lixo pode-se perceber, com a tradagem, que a cobertura dos resíduos é delgada, em torno de 20 centímetros, e isso impossibilitou a identificação da profundidade da frente de molhamento. 


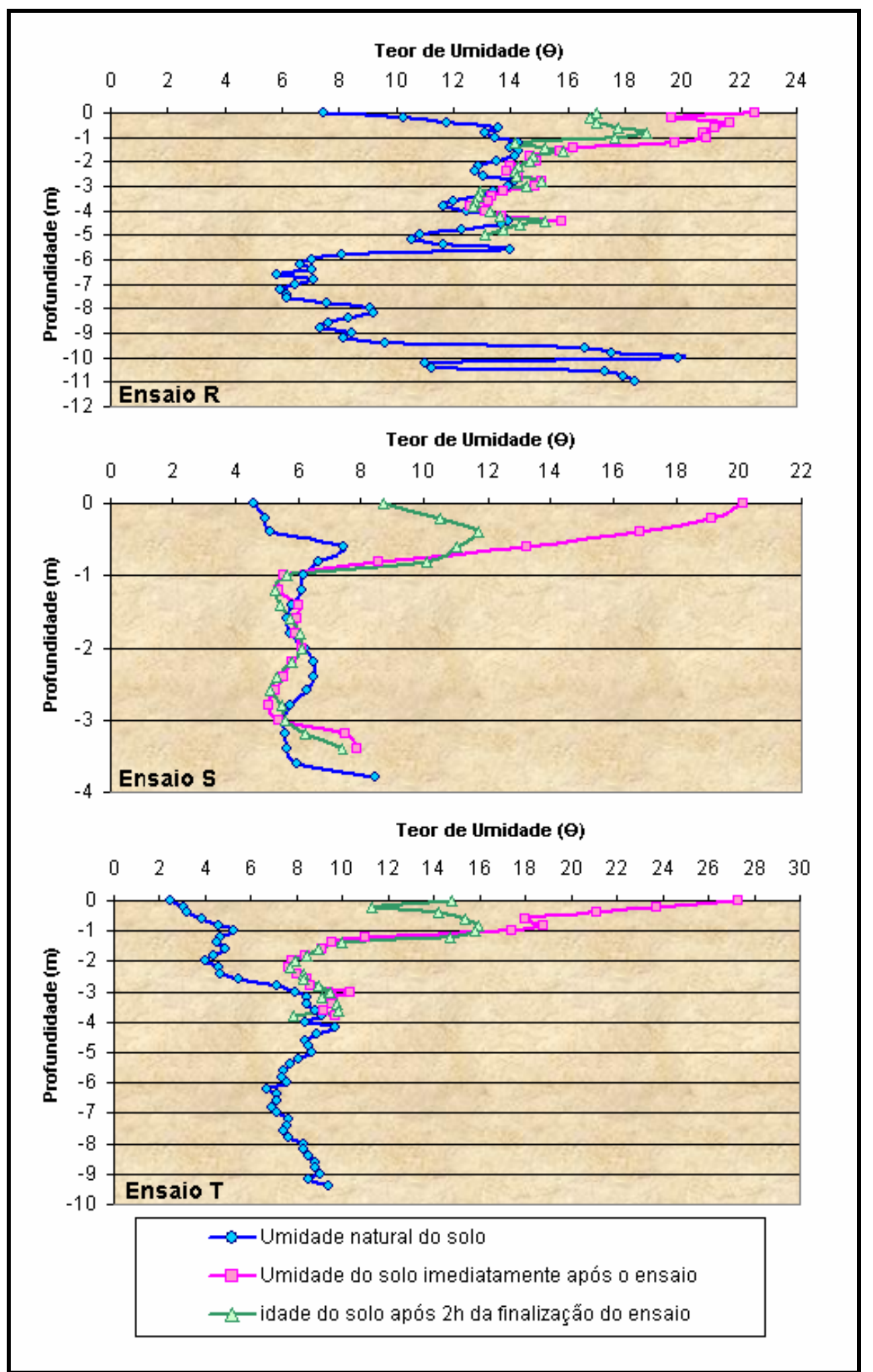

Figura 24: Gráfico dos ensaios R,S e T, relacionando as três umidades, caracterizandoa frente de molhamento.

Também nota-se que a condutividade hidráulica nesses pontos não apresenta diferenças significativas para as condutividades encontradas para os ensaios " $R$ ", " $S$ " e "T", onde não existe porções de lixo (Tabela 3). 
Tabela 3: Dados dos Ensaios de Infiltração

\begin{tabular}{|c|c|c|c|c|}
\hline Ensaio & $\begin{array}{c}\text { Prof. Máx. } \\
\text { Tradagem } \\
(\mathbf{m})\end{array}$ & $\begin{array}{c}\text { Prof. frente } \\
\text { Molhamento } \\
\mathbf{( \mathbf { m } )}\end{array}$ & $\begin{array}{c}\text { Taxa de infiltração } \\
\text { estabilizada ( m m/ h) }\end{array}$ & $\begin{array}{c}\text { Condutividade } \\
\text { Hidráulica (m/ s) }\end{array}$ \\
\hline \hline $\mathbf{R}$ & 11 & 1,8 & 90 & $2,37 * 10^{-5}$ \\
\hline $\mathbf{S}$ & 3,8 & 1,0 & 240 & $6,19 * 10^{-5}$ \\
\hline $\mathbf{T}$ & 9,4 & 3,6 & 235 & $6,25 * 10^{-5}$ \\
\hline $\mathbf{U}$ & 0,2 & 0,2 & 50 & $7,73 * 10^{-6}$ \\
\hline $\mathbf{V}$ & 0,15 & 0,15 & 100 & $1,33 * 10^{-5}$ \\
\hline
\end{tabular}

\subsection{Ensaios de caracterização dos materiais inconsolidados}

Para caracterização dos materiais inconsolidados foram realizados os seguintes ensaios:

- determinação da massa específica dos sólidos ( $\rho s)$ segundo a norma ABNTNBR6508/84;

- determinação da massa específica aparente seca ( $\rho d)$, conforme proposto por Zuquette (1987);

- granulometria conjunta conforme a norma ABNT - NBR7181/84;

- adsorção de azul de metileno segundo procedimentos apresentados por Pejon (1992).

\subsubsection{Locação dos pontos ensaiados}

Para realização dos ensaios de caracterização foram coletadas amostras em superfície em 9 pontos e em 5 furos a trado (Figura 25).

Nos furos a trado (pontos $\mathrm{R}, \mathrm{S}, \mathrm{T}, \mathrm{U}$ e $\mathrm{V}$ ) foram coletadas amostras de metro em metro para os ensaios de granulometria, ps, e adsorção de azul de metileno. Nos demais pontos foram obtidos também amostras indeformadas com anel de PVC (10 $\mathrm{cm}$ de diâmetro por $5 \mathrm{~cm}$ de altura) para determinação de $\rho$ d. 


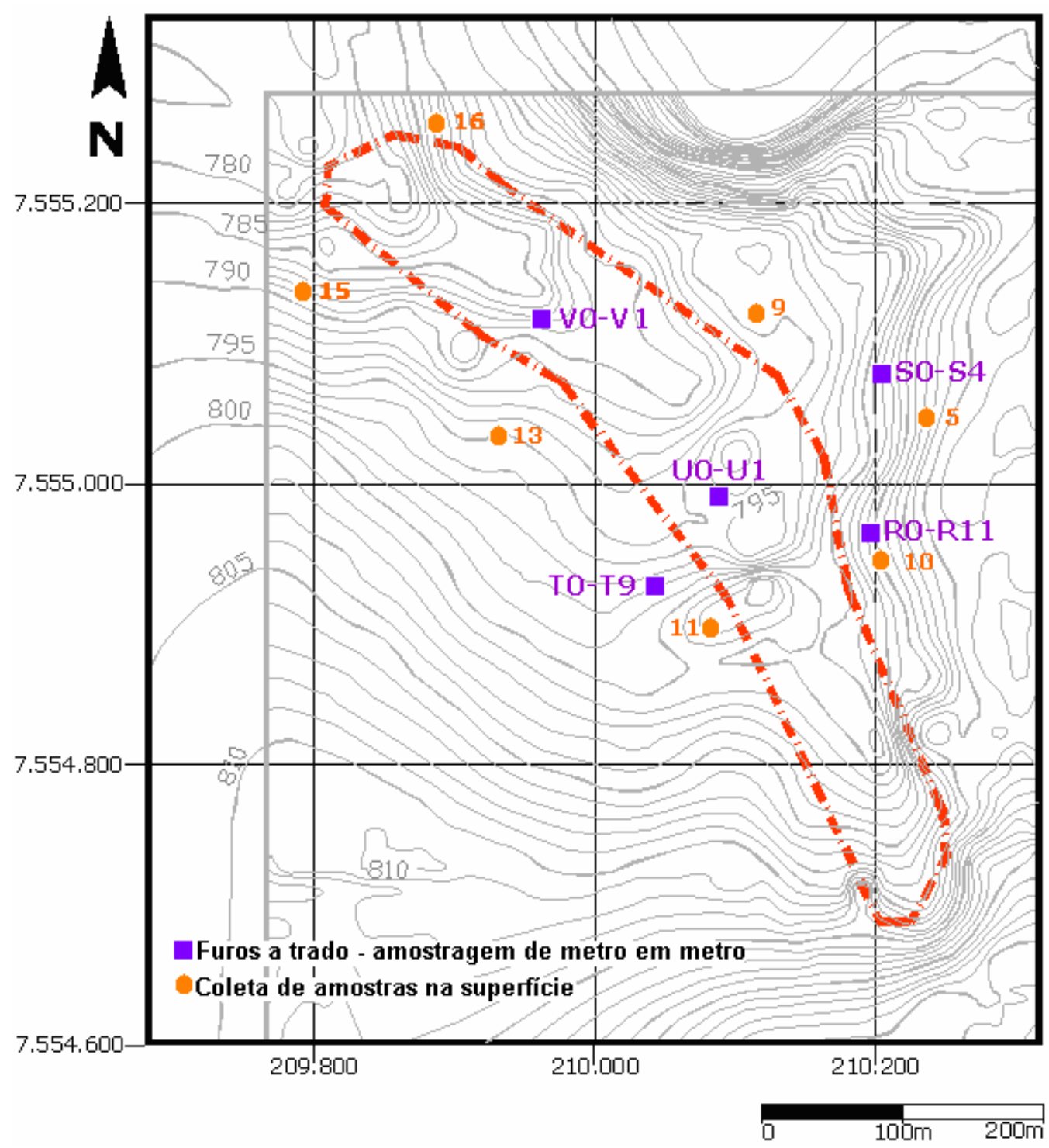

Figura 25: Localização dos pontos onde foram coletadas amostras para os ensaios de caracterização de materiais inconsolidados.

\subsubsection{Resultados}

Os resultados obtidos através dos ensaios de massa específica apresentam-se sintetizados na Tabela 4, enquanto que as curvas granulometricas produzidas para cada amostra dos ensaios de granulometria conjunta podem ser visualizadas no Anexo v.

A partir desses índices pode-se perceber que esses materiais inconsolidados apresentam porosidade elevada, massa específica média de $1,69 \mathrm{~g} / \mathrm{cm}^{3}$ e massa específica seca média de $1,60 \mathrm{~g} / \mathrm{cm}^{3}$. 
Tabela 4: Dados obtidos com os ensaio de íncices físicos realizados.

\begin{tabular}{|c|c|c|c|c|c|c|c|}
\hline Amostra & $\begin{array}{c}\text { massa } \\
\text { específica } \\
\left(\rho=g / \mathrm{cm}^{3}\right)\end{array}$ & $\begin{array}{l}\text { umidade } \\
\text { média } \\
(w=\%)\end{array}$ & $\begin{array}{c}\text { massa } \\
\text { específica } \\
\text { seca } \\
\left(\rho d=g / \mathrm{cm}^{3}\right)\end{array}$ & $\begin{array}{c}\text { massa } \\
\text { específica } \\
\text { dos sólidos } \\
\left(\rho s=\mathrm{g} / \mathrm{cm}^{3}\right)\end{array}$ & $\begin{array}{c}\text { índice } \\
\text { de } \\
\text { vazios } \\
\text { (e) }\end{array}$ & $\begin{array}{c}\text { porosi- } \\
\text { dade } \\
(n=\%)\end{array}$ & $\begin{array}{c}\text { grau de } \\
\text { saturação } \\
(\mathrm{Sr}=\%)\end{array}$ \\
\hline 1 & 1,66 & 2,27 & 1,62 & 2,67 & 0,65 & 39,2 & 9,4 \\
\hline 2 & 1,60 & 1,80 & 1,57 & 2,67 & 0,70 & 41,2 & 6,9 \\
\hline 3 & 1,62 & 2,26 & 1,58 & 2,67 & 0,69 & 40,8 & 8,8 \\
\hline 4 & 1,70 & 2,89 & 1,65 & 2,67 & 0,62 & 38,2 & 12,4 \\
\hline 5 & 1,62 & 2,81 & 1,57 & 2,67 & 0,70 & 41,1 & 10,8 \\
\hline 6 & 1,66 & 2,86 & 1,61 & 2,67 & 0,66 & 39,8 & 11,6 \\
\hline 7 & 1,71 & 2,93 & 1,66 & 2,67 & 0,61 & 37,8 & 12,9 \\
\hline 8 & 1,68 & 4,41 & 1,61 & 2,67 & 0,66 & 39,7 & 17,9 \\
\hline 9 & 1,75 & 22,25 & 1,43 & 2,69 & 0,88 & 46,9 & 67,7 \\
\hline 10 & 1,76 & 8,77 & 1,61 & 2,68 & 0,66 & 39,8 & 35,6 \\
\hline 11 & 1,56 & 2,28 & 1,52 & 2,67 & 0,75 & 42,9 & 8,1 \\
\hline 12 & 1,73 & 5,90 & 1,64 & 2,67 & 0,63 & 38,7 & 25,0 \\
\hline 13 & 1,68 & 3,85 & 1,62 & 2,67 & 0,65 & 39,5 & 15,8 \\
\hline 14 & 1,63 & 3,50 & 1,57 & 2,67 & 0,70 & 41,1 & 13,4 \\
\hline 15 & 1,72 & 5,05 & 1,63 & 2,67 & 0,64 & 38,8 & 21,2 \\
\hline 16 & 1,92 & 11,92 & 1,72 & 2,67 & 0,55 & 35,7 & 57,4 \\
\hline
\end{tabular}

Com a caracterização dos sedimentos da área do lixo pôde-se concluir que são predominantemente arenosos finos a médios, pontualmente mais argilosos, com no máximo 34\% de argila, como pode ser observado na Tabela 5.

Tabela 5: Dados obtidos com os ensaio de granulometria conjunta (frações granulométricas segundo ABNT - NBR6502/95).

\begin{tabular}{|c|c|c|c|c|c|}
\hline $\begin{array}{c}\text { Amos- } \\
\text { tra }\end{array}$ & $\begin{array}{c}\text { Argila } \\
\%\end{array}$ & $\begin{array}{c}\text { Silte } \\
\%\end{array}$ & $\begin{array}{c}\text { Areia } \\
\text { Fina } \\
\%\end{array}$ & $\begin{array}{c}\text { Areia } \\
\text { Média } \\
\%\end{array}$ & $\begin{array}{c}\text { Areia } \\
\text { Gros. } \\
\%\end{array}$ \\
\hline \hline 5 & 6 & 2 & 50 & 42 & 0 \\
\hline 9 & 21 & 13 & 33 & 31 & 2 \\
\hline $\mathbf{1 0}$ & 19 & 7 & 36 & 37 & 1 \\
\hline 11 & 4 & 5 & 52 & 38 & 1 \\
\hline 13 & 7 & 4 & 42 & 46 & 1 \\
\hline 15 & 12 & 24 & 41 & 22 & 1 \\
\hline 16 & 10 & 5 & 46 & 38 & 1 \\
\hline R 0 & 20 & 9 & 35 & 35 & 1 \\
\hline R 1 & 29 & 8 & 33 & 30 & 0 \\
\hline R 2 & 28 & 9 & 33 & 30 & 0 \\
\hline R 3 & 28 & 9 & 32 & 31 & 0 \\
\hline R 4 & 24 & 6 & 35 & 35 & 0 \\
\hline R 5 & 18 & 5 & 38 & 38 & 1 \\
\hline R 6 & 8 & 4 & 40 & 48 & 0 \\
\hline R 7 & 9 & 4 & 39 & 46 & 2 \\
\hline R 8 & 10 & 7 & 39 & 42 & 2 \\
\hline R 9 & 9 & 3 & 33 & 55 & 0 \\
\hline R 10 & 34 & 8 & 31 & 27 & 0 \\
\hline R 11 & 16 & 6 & 40 & 38 & 0 \\
\hline
\end{tabular}

\begin{tabular}{|c|c|c|c|c|c|}
\hline $\begin{array}{c}\text { Amos- } \\
\text { tra }\end{array}$ & $\begin{array}{c}\text { Argila } \\
\%\end{array}$ & $\begin{array}{c}\text { Silte } \\
\%\end{array}$ & $\begin{array}{c}\text { Areia } \\
\text { Fina } \\
\%\end{array}$ & $\begin{array}{c}\text { Areia } \\
\text { Média } \\
\%\end{array}$ & $\begin{array}{c}\text { Areia } \\
\text { Gros. } \\
\%\end{array}$ \\
\hline \hline S 0 & 7 & 3 & 41 & 49 & 0 \\
\hline S 1 & 10 & 3 & 40 & 47 & 0 \\
\hline S 2 & 10 & 28 & 45 & 17 & 0 \\
\hline S 3 & 7 & 3 & 41 & 49 & 0 \\
\hline S 4 & 10 & 4 & 42 & 42 & 2 \\
\hline T 0 & 6 & 7 & 47 & 40 & 0 \\
\hline T 1 & 13 & 4 & 43 & 40 & 0 \\
\hline T 2 & 10 & 5 & 43 & 42 & 0 \\
\hline T 3 & 14 & 6 & 46 & 33 & 1 \\
\hline T 4 & 17 & 8 & 37 & 34 & 4 \\
\hline T 5 & 15 & 5 & 43 & 36 & 1 \\
\hline T 6 & 12 & 5 & 43 & 39 & 1 \\
\hline T 7 & 10 & 5 & 47 & 38 & 0 \\
\hline T 8 & 10 & 13 & 50 & 27 & 0 \\
\hline T 9 & 8 & 8 & 50 & 34 & 0 \\
\hline U 0 & 24 & 12 & 34 & 29 & 1 \\
\hline U 1 & 29 & 10 & 33 & 26 & 2 \\
\hline V 0 & 11 & 5 & 44 & 38 & 2 \\
\hline V 1 & 11 & 5 & 38 & 40 & 6 \\
\hline
\end{tabular}


A partir do volume de corante gasto durante cada ensaio de adsorção de azul de metileno, foram calculados os valores de Capacidade de Troca Catiônica (CTC) e Superfície Específica (SE) dos argilominerais, além do Índice de Atividade da fração argilosa (Acb) e do Valor de Azul de Metileno Adsorvido (Vb), que podem ser visualizados na Tabela 6.

Tabela 6: Dados obtidos com os ensaio de adsorção de azul de metileno.

\begin{tabular}{|c|c|c|c|c|}
\hline Amostra & $\begin{array}{c}\text { CTC } \\
\text { ( } \mathbf{m e q} / \\
\mathbf{1 0 0 g}\end{array}$ & $\begin{array}{c}\text { SE } \\
\text { ( } \mathbf{~}^{\mathbf{2}} \mathbf{~ g )}\end{array}$ & Vb & Acb \\
\hline \hline $\mathbf{5}$ & 1,209 & 9,440 & 0,386 & 7,015 \\
\hline $\mathbf{9}$ & 2,452 & 19,145 & 0,783 & 3,762 \\
\hline $\mathbf{1 0}$ & 1,857 & 14,502 & 0,593 & 3,187 \\
\hline $\mathbf{1 1}$ & 0,469 & 3,661 & 0,150 & 4,156 \\
\hline $\mathbf{1 3}$ & 1,007 & 7,866 & 0,322 & 4,798 \\
\hline $\mathbf{1 5}$ & 0,694 & 5,420 & 0,222 & 1,816 \\
\hline $\mathbf{1 6}$ & 3,089 & 24,116 & 0,986 & 9,759 \\
\hline R 0 & 2,260 & 17,645 & 0,721 & 3,606 \\
\hline R 1 & 4,311 & 33,666 & 1,376 & 4,811 \\
\hline R 2 & 3,534 & 27,597 & 1,128 & 4,000 \\
\hline R 3 & 3,903 & 30,476 & 1,246 & 4,433 \\
\hline R 4 & 3,485 & 27,213 & 1,112 & 4,693 \\
\hline R 5 & 1,819 & 14,204 & 0,581 & 3,207 \\
\hline R 6 & 0,886 & 6,915 & 0,283 & 3,671 \\
\hline R 7 & 1,481 & 11,567 & 0,473 & 5,029 \\
\hline R 8 & 2,403 & 18,764 & 0,767 & 7,374 \\
\hline R 9 & 1,046 & 8,168 & 0,334 & 3,882 \\
\hline R 10 & 4,568 & 35,669 & 1,458 & 4,339 \\
\hline R 11 & 2,652 & 20,704 & 0,846 & 5,356 \\
\hline
\end{tabular}

\begin{tabular}{|c|c|c|c|c|}
\hline Amostra & $\begin{array}{c}\text { CTC } \\
\text { (meq/ } \\
100 \mathrm{~g})\end{array}$ & $\begin{array}{c}\text { SE } \\
\left(\mathrm{m}^{2} / \mathrm{g}\right)\end{array}$ & Vb & Acb \\
\hline S 0 & 0,749 & 5,852 & 0,239 & 3,680 \\
\hline S 1 & 1,040 & 8,117 & 0,332 & 3,351 \\
\hline 52 & 0,922 & 7,198 & 0,294 & 3,065 \\
\hline 53 & 0,800 & 6,244 & 0,255 & 3,545 \\
\hline 54 & 1,471 & 11,488 & 0,470 & 4,388 \\
\hline TO & 0,609 & 4,757 & 0,194 & 3,136 \\
\hline T 1 & 1,091 & 8,522 & 0,348 & 2,700 \\
\hline T 2 & 0,915 & 7,144 & 0,292 & 2,808 \\
\hline T 3 & 1,240 & 9,678 & 0,396 & 2,786 \\
\hline T 4 & 2,492 & 19,457 & 0,795 & 4,820 \\
\hline T 5 & 2,311 & 18,047 & 0,738 & 4,918 \\
\hline T 6 & 1,739 & 13,576 & 0,555 & 4,784 \\
\hline T 7 & 1,583 & 12,357 & 0,505 & 4,904 \\
\hline T 8 & 1,618 & 12,632 & 0,516 & 4,964 \\
\hline T 9 & 1,187 & 9,272 & 0,379 & 4,986 \\
\hline U 0 & 3,673 & 28,679 & 1,172 & 4,824 \\
\hline U 1 & 4,588 & 35,822 & 1,464 & 4,980 \\
\hline V 0 & 1,620 & 12,648 & 0,517 & 4,743 \\
\hline V 1 & 1,711 & 13,358 & 0,546 & 4,875 \\
\hline
\end{tabular}

A partir desses resultados, conjuntamente com os valores de porcentagem de argila obtidos nos ensaios de granulometria conjunta pôde-se constatar que, em sua maior parte, as argilas são de composição caulinítica, além de serem inativas a pouco ativas, predominantemente. 


\section{Análise e Discussão dos Resultados}

\subsection{Seções Geofísicas}

Para análise dos resultados foi feita a interpretação dos perfis geofisicos, que consiste na busca de anomalias. Como os dados geofísicos foram tratados em dois programas, o Surfer 8.0 e o RES2DINV 3.2, foram gerados duas seções geofísicas para cada linha, que foram inicialmente comparadas (Anexo II).

Como o Surfer 8.0 é um programa apenas de interpolação, enquanto que o RES2DINV é um programa próprio para inversão de dados de resistividade e polarização induzida, as seções modeladas a partir do RES2DINV são resultantes de um processo automático de inversão bi-dimensional e representam a provável distribuição real dos valores de resistividade e cargabilidade em subsuperfície, de tal forma que optou-se por trabalhar com essas seções. Outra vantegem do RES2DINV é que este programa permite a plotagem dos valores de topografia conjuntamente com as seções modeladas.

O Surfer 8.0 mostrou-se útil para geração dos mapas de resistividade, apresentados no fim deste capítulo, bem como na comparação imediata entre as linhas realizadas nos mesmo locais, mas em datas distintas, já que permite manuseio em sua escala de cores, proporcionando as mesmas cores para mesmos valores de resistividade ou cargabilidade, opção não disponível no RES2DINV 3.2.

Para uma análise mais completa dos dados geofísicos, agrupou-se a esse conjunto de informações os dados obtidos por Freitas (1996) na execução de poços de monitoramento na área e os dados gerados por Álvares (2000) a partir de perfilagens 
geofísicas nesses poços, além das observações de campo e ensaios de laboratório realizados no presente estudo, que serão discutidos linha a linha.

Deve-se lembrar que a resistividade elétrica, e seu inverso, a condutividade elétrica, estão diretamente ligadas aos mecanismos de propogação de corrente elétrica dos materiais. Essas propriedades podem variar devido a presença de materias metálicos e grafita no solo ou devido a deslocamento de íons dissolvidos na água contida nos poros e fissuras de solos e rochas.

De maneira geral essa condutividade pode ser afetada pela composição mineralógica, pela porosidade, pelo teor de água ou pela quantidade e natureza dos sais dissolvidos, nesse estudo acredita-se que as anomalias geofisicas encontradas nos perfis de resistividade, em sua maioria, estão associadas aos resíduos e a contaminação gerada pelo percolado, de elevada quantidade de sais dissolvidos.

Esses valores devem ser analisados em conjunto, de maneira relativa para identificação dos contrastes, pois o parâmetro resisitividade pode variar entre largos limites, mesmo para um único tipo de rocha, segundo Orellana (1972) apud Elis (1998) as águas doces superficiais podem apresentar resisitividades da ordem de 10 a $10^{3} \mathrm{ohm} . \mathrm{m}$, os arenitos de 10 a $10^{8} \mathrm{ohm} . \mathrm{m}$, as argilas de 10 a $10^{2} \mathrm{ohm} . \mathrm{m}$, e as areias de $10^{2}$ a $10^{4}$ ohm.m.

\subsubsection{Linha 0}

Como a linha 0 não passa por nenhum dos poços de monitoramento não foi possível a confecç̧ão do perfil geofísico juntamente com os dados de substrato, mas observando a seção de resisitividade (Figura 26), pode-se notar valores baixos na porção de topografia menos elevada, mas não se pode afirmar com tanta certeza que correspondam a contaminação subsuperficial, já que esses valores estão situados onde passa o córrego.

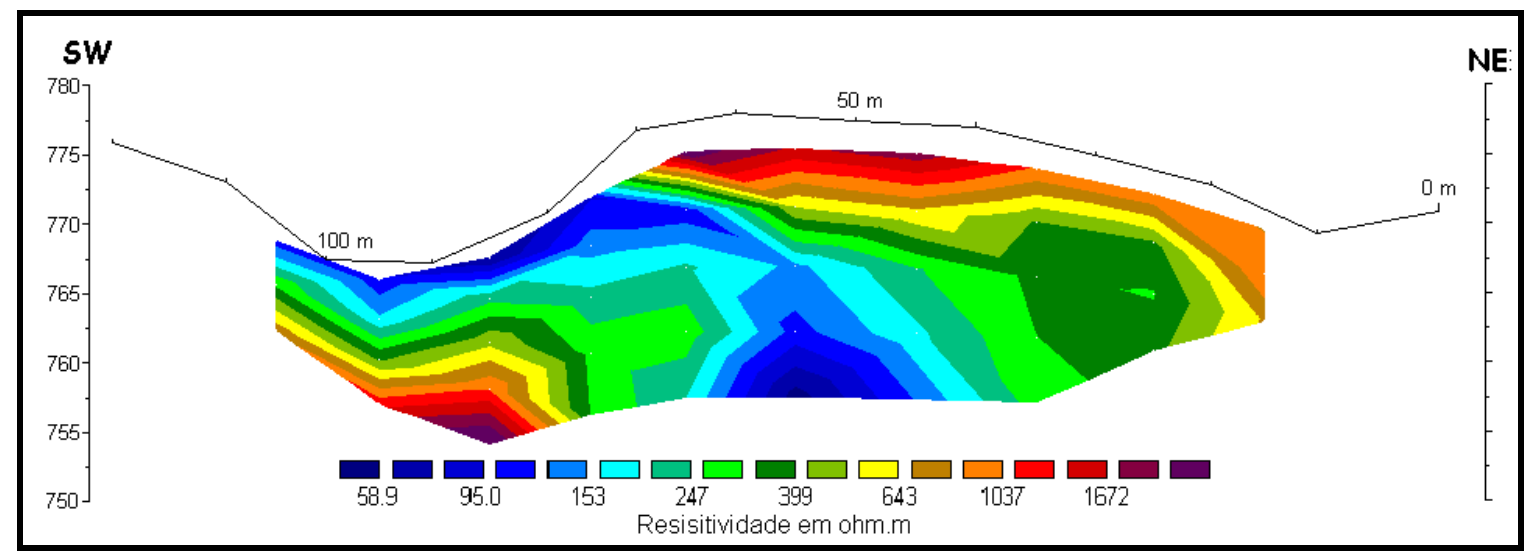

Figura 26:Seção de resistividade (RES2DINV) da linha 0. 
Para confirmação desses valores foi realizada a coleta de água desse córrego em dois pontos distintos, um logo a jusante do corpo de lixo e o outro próximo a linha 0 . Pôde-se verificar valores de baixa resistividade em ambos os pontos (70,4 ohm.m e 84,03 ohm.m, respectivamente), caracterizando portanto a contaminação da água do córrego, em superfície.

Os valores de baixa resistividade encontrados no centro da linha, em sua porção inferior, pode caracterizar que os percolados que seguem o fluxo preferencial SE-NW, estejam se deslocando pela porção inferior nessa seção.

Quando analisam-se os dados de cargabilidade desta linha (Figura 27), pode-se perceber a coincidência de valores de baixa resistividade com os de baixa cargabilidade ou alta cargabilidade, dependendo da porção analisada. Apesar da identificação da anomalia, não é possível fazer nenhuma associação concreta, uma vez que a cargabilidade tende a crescer com o aumento da concentração de sais, mas que a partir de uma determinada concentração o comportamento se inverte, tendendo a valores muito baixos (Elis, 2000).

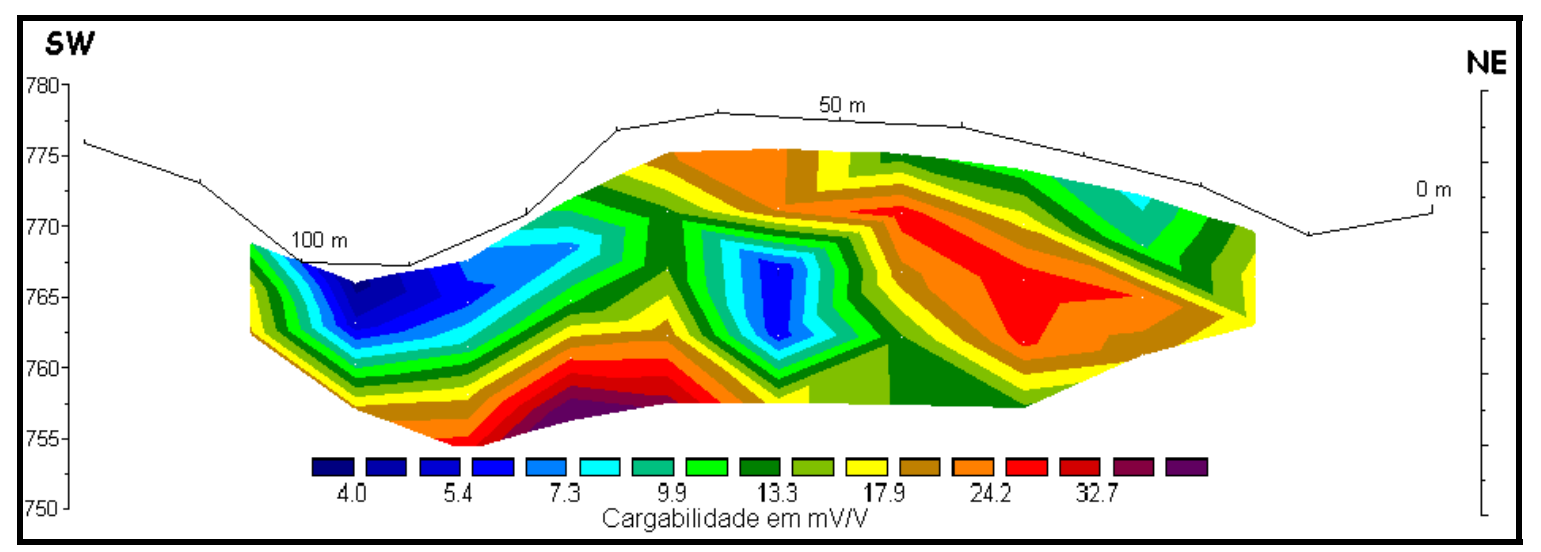

Figura 27: Seção de cargabilidade (RES2DINV) da linha 0.

\subsubsection{Linha 1}

Quando Freitas (1996) instalou os poços de monitoramento e analisou as amostras que eram deles retiradas, percebeu a presença de uma delgada porção com resíduos ( 1 metro de areia fina com resíduos no poço 28) e logo abaixo uma zona (8 $\mathrm{m}$, até o fim do poço) afetada pela presença de percolados. Quando analisamos o perfil desse poço, conjuntamente com os dados geofísicos, observamos a correlação dessas porções (resíduos e percolados) com as de baixa resistividade (até 150 ohm.m), como era de se esperar.

Pode-se perceber que o poço 27 , no qual não foi encontrada a presença nem de resíduos, nem de percolados, apresenta altos valores de resistividade. 


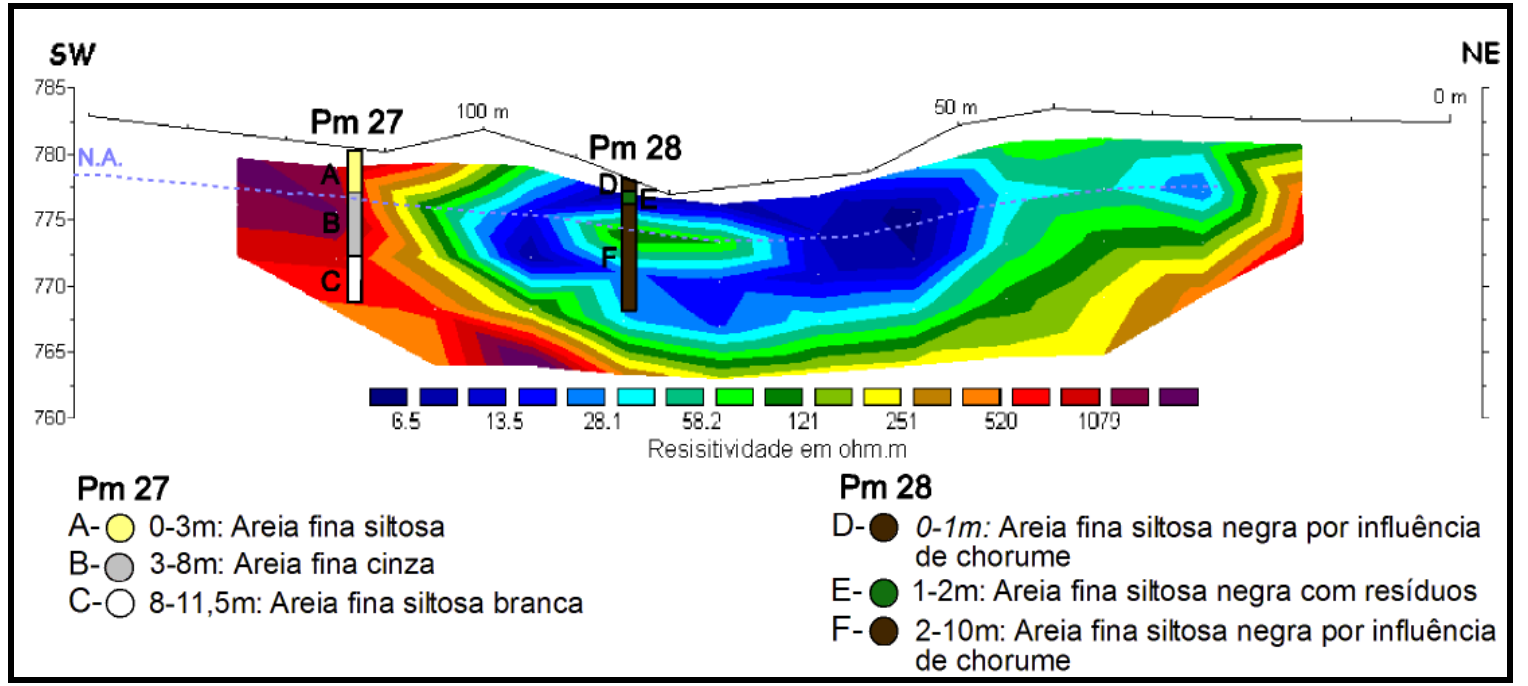

Figura 28: Seção de resistividade (RES2DINV) da linha 1, nível d'água medido e dados da composição dos poços (Freitas, 1995 e Álvares 2000).

Essa zona de baixa resistividade (até 150 ohm.m pelo menos) pode indicar uma zona contaminada por percolados, fortalecendo a idéia de um fluxo subterrâneo de sentido NW, como sugerido por Ellert (1990), Gonçalves et al. (1992), Bossolan (1993), Freitas (1996), Gadoti (1997) e Álvares (2000).

Observando a seção de polarização induzida da linha 1 (Figura 29) pode-se perceber a presença de uma anomalia de baixa cargabilidade junto ao poço 28 , provavelmente provocado pela presença de seus materiais constituintes. Mas observase que este comportamento não é via de regra, já que no poço 27 , construído como o 28, não é observada a mesma resposta de cargabilidade, portanto não se pode confirmar essa associação.

Já a anomalia de alta cargabilidade no centro da seção, que corresponde a uma porção de baixa resistividade, pode estar associada a uma zona de percolação dos fluidos. Essa anomalia está presente em outras linhas, e será melhor discutida posteriormente. 


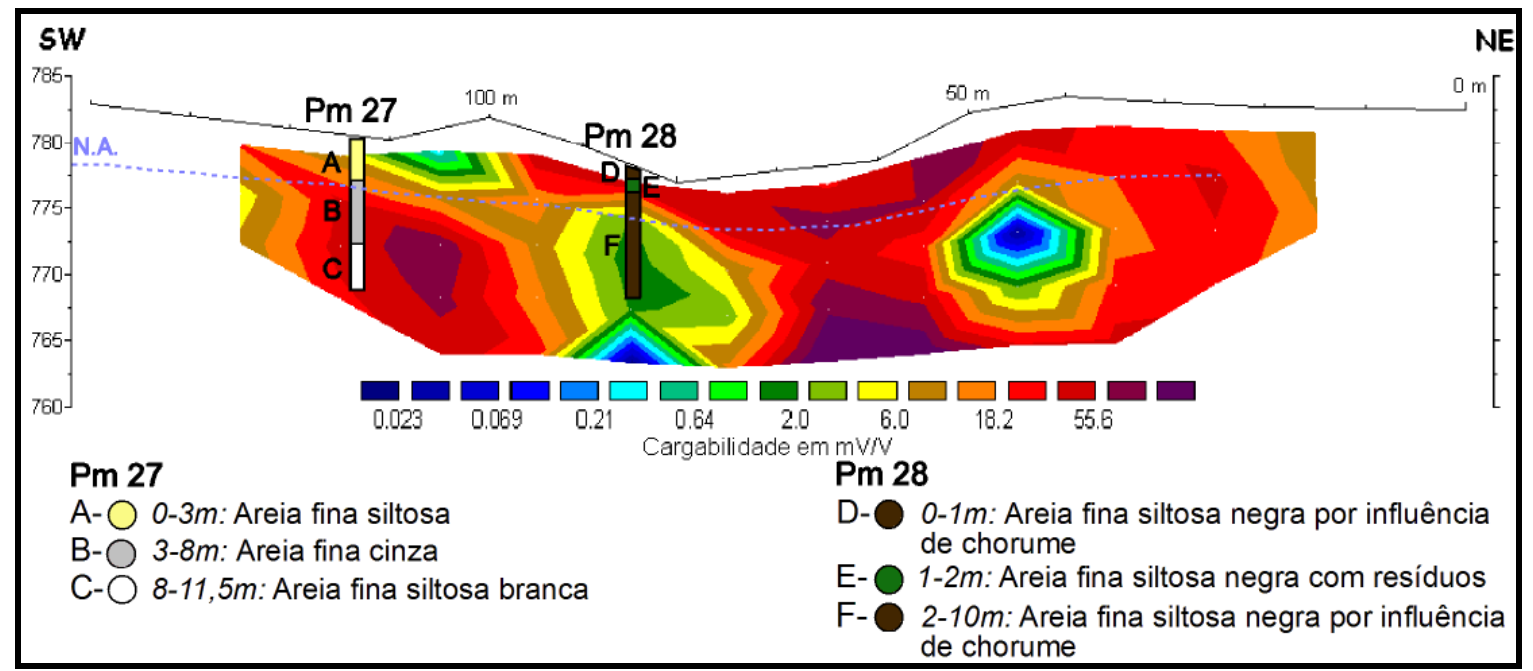

Figura 29: Seção de cargabilidade (RES2DINV) da linha 1, nível d'água medido e dados da composição dos poços (Freitas, 1995 e Álvares 2000).

\subsubsection{Linha 2}

Tanto na seção de resistividade (Figura 30), quanto na seção de cargabilidade (Figura 31), em conjunto com a composição dos poços que se encontram nessa linha, pode-se fazer as mesmas análises feitas na linha 1 . Ou seja, as anomalias de baixa resistividade coincidem com as porções compostas por resíduos e percolados, assim como as de alta cargabilidade.

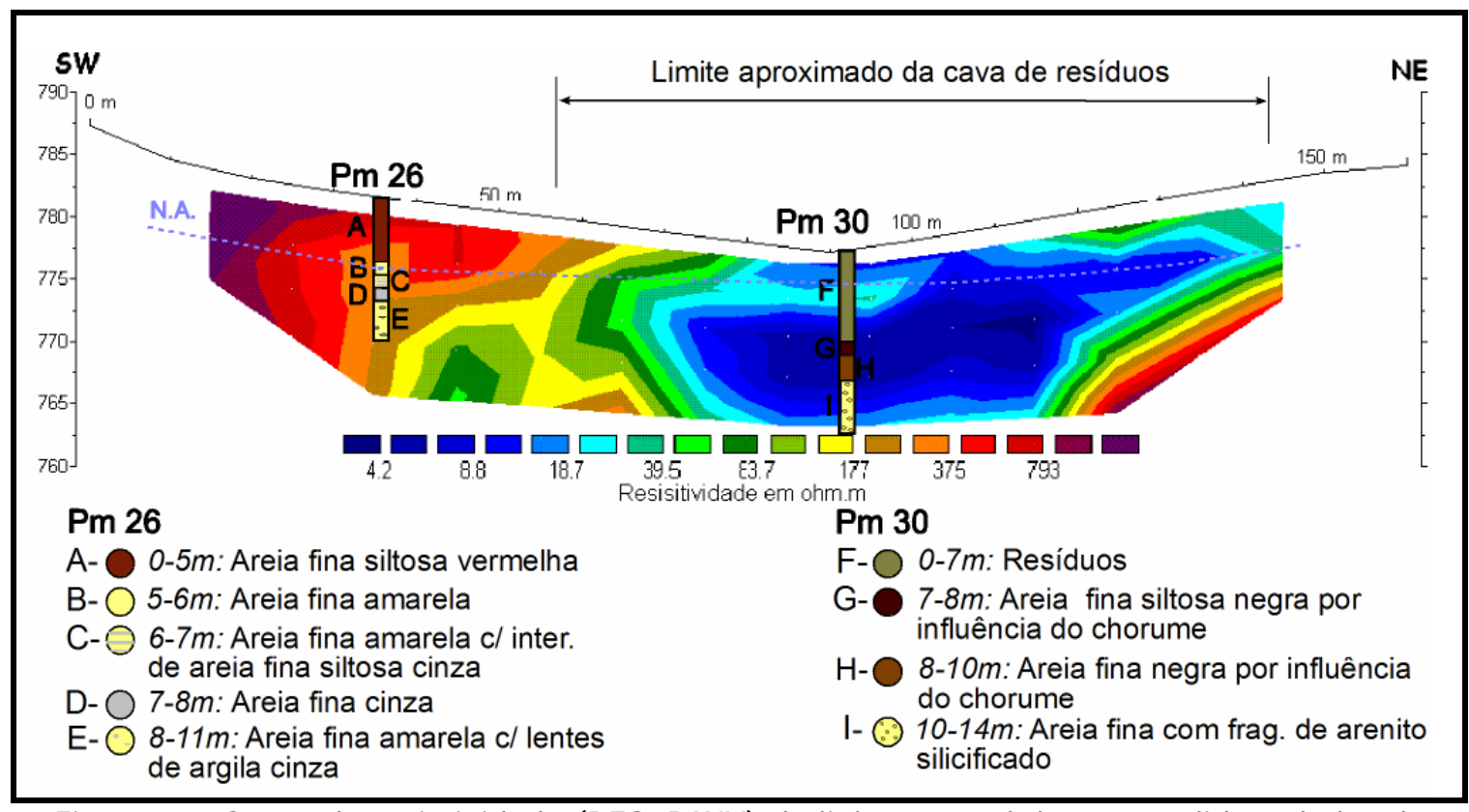

Figura 30: Seção de resistividade (RES2DINV) da linha 2, nível d'água medido e dados da composição dos poços (Freitas, 1995 e Álvares 2000). 


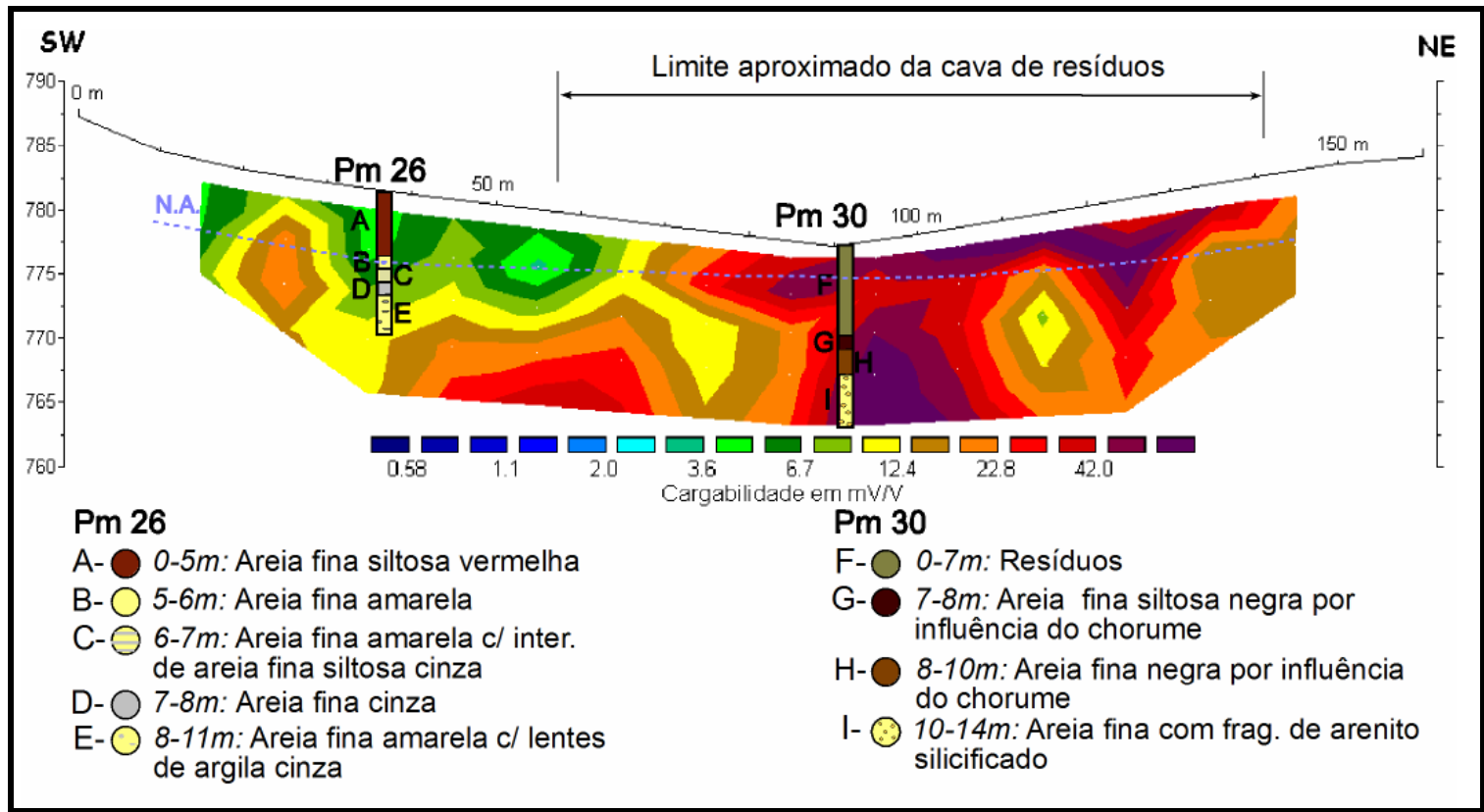

Figura 31: Seção de cargabilidade (RES2DINV) da linha 2, nível d'água medido e dados da composição dos poços (Freitas, 1995 e Álvares 2000).

\subsubsection{Linha 3}

Na seção de resistividade produzida para esta linha (Figura 32) observa-se novamente a presença de uma área de baixa resistividade correspondente a área da cava de resíduos e seus percolados. Observando o poço 31 pode-se perceber que a profundidade de resíduos chega a 6,5 metros, mas que a presença de percolados encontra-se abaixo desse valor, sendo que até 15 metros é confirmada pelos dados de Freitas (1995), e abaixo disso indicada em algumas porções pelos baixos valores de resistividade.

Foram encontrados valores de baixa resistividade que interceptam o poço 25 , no entanto, os dados do material retirado do poço não indicam a presença de lixo ou chorume. Quando analisa-se o perfil corespondente de 1995 (Anexo II - linha 5 de 1995), já é observada essa anomalia de baixa resistividade nessa porção. 


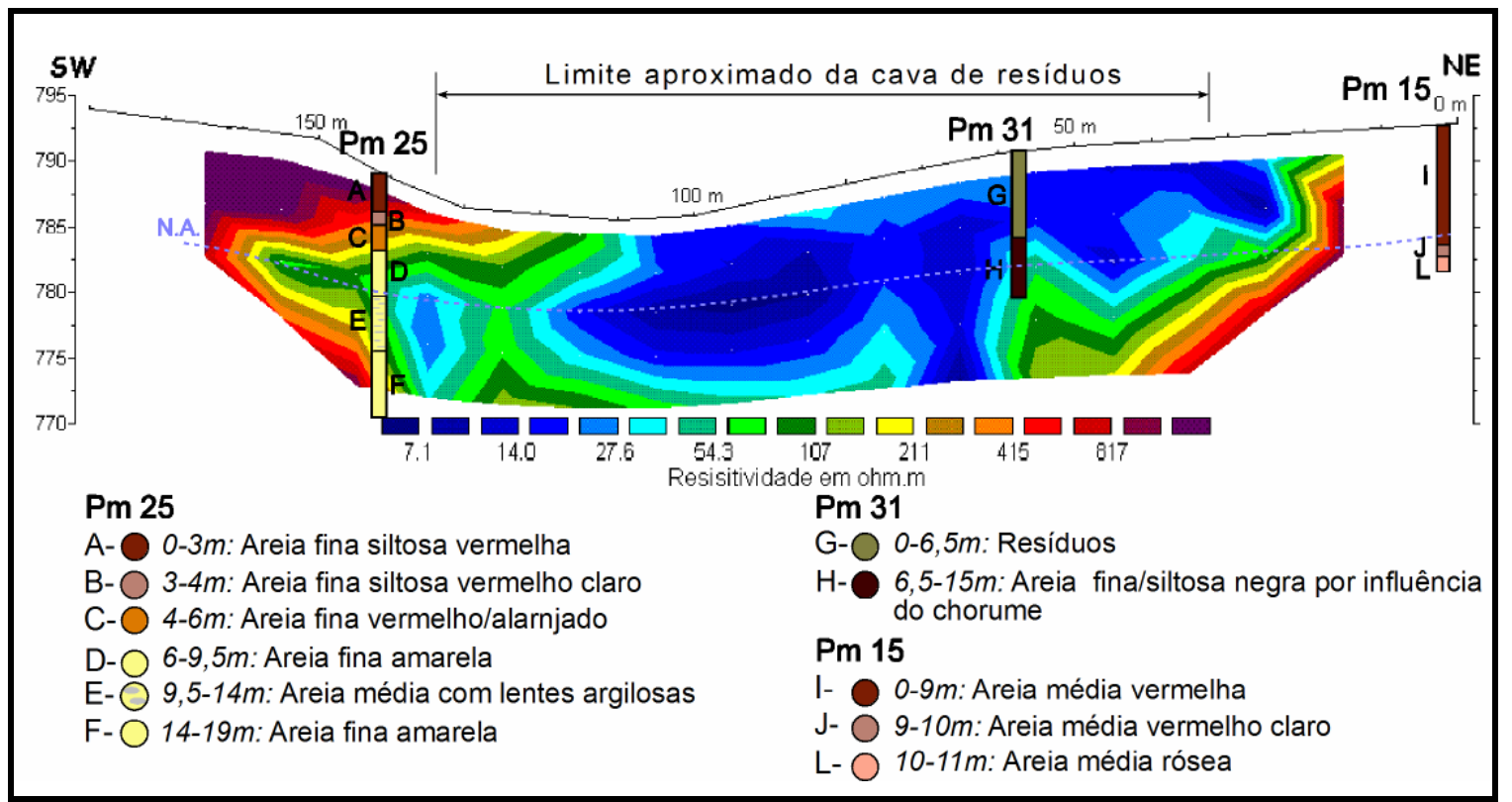

Figura 32: Seção de resistividade (RES2DINV) da linha 3, nível d'água medido e dados da composição dos poços (Freitas, 1995 e Álvares 2000).

Na seção de cargabilidade da linha 3 (Figura 33) pode-se confirmar os valores altos relacionados aos locais em que encontram-se os resíduos e percolados, bem como, mais uma vez, pode-se observar a presença de uma porção de alta cargabilidade praticamente vertical, quase no centro da linha, que pode indicar um caminho preferencial de percolação.

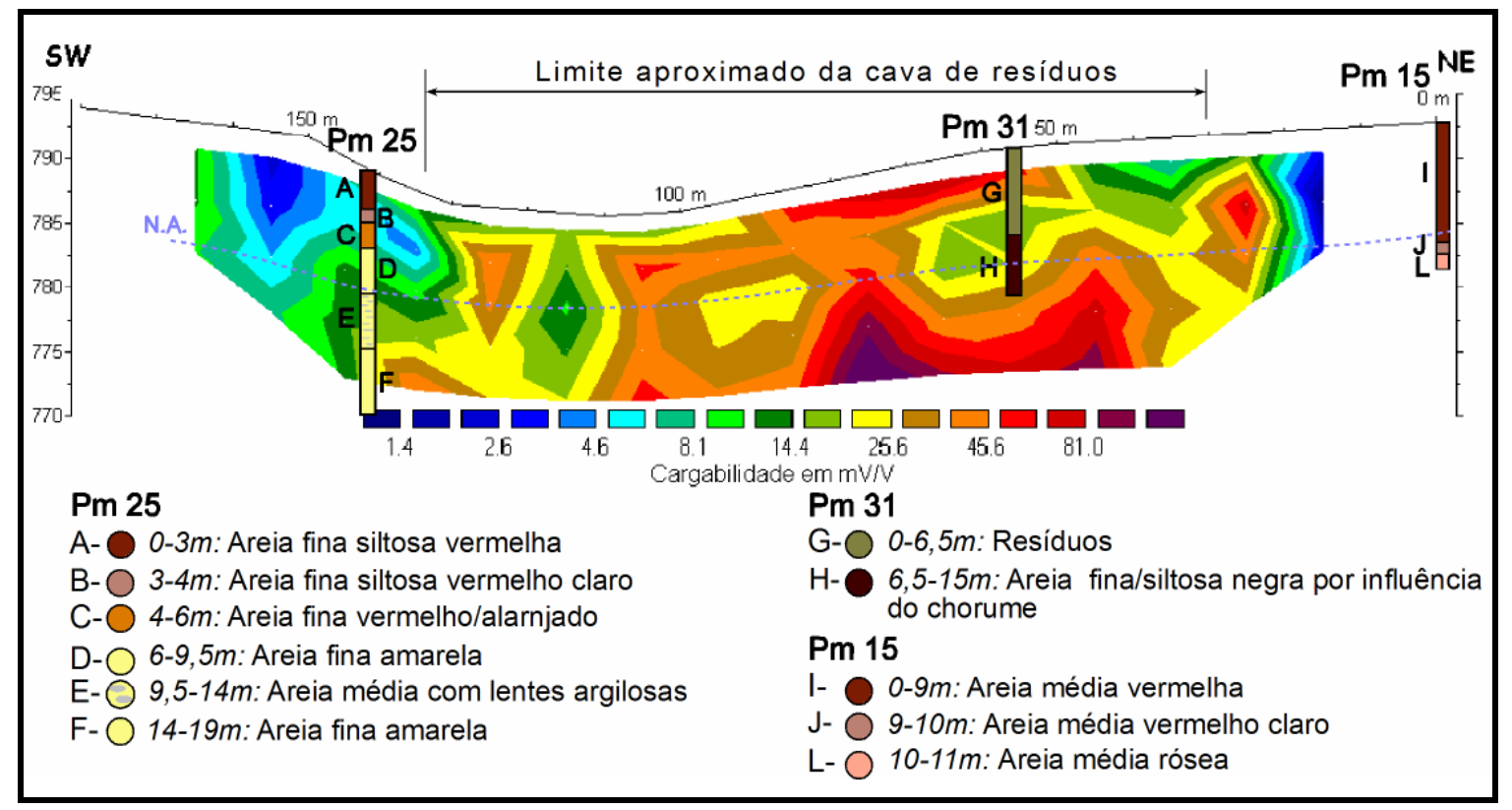

Figura 33: Seção de cargabilidade (RES2DINV) da linha 3, nível d'água medido e dados da composição dos poços (Freitas, 1995 e Álvares 2000). 


\subsubsection{Linha 4}

Como o único poço que a linha 4 intercepta (poço 16) encontra-se fora do limite da cava de resíduos, não foi possível correlacionar os dados de poços com os de resistividade ou cargabilidade, no entanto, a presença de uma zona de baixa resistividade no centro da linha (Figura 34 ) indica a presença de resíduos e percolados até a profundidade de, pelo menos, 15 metros.

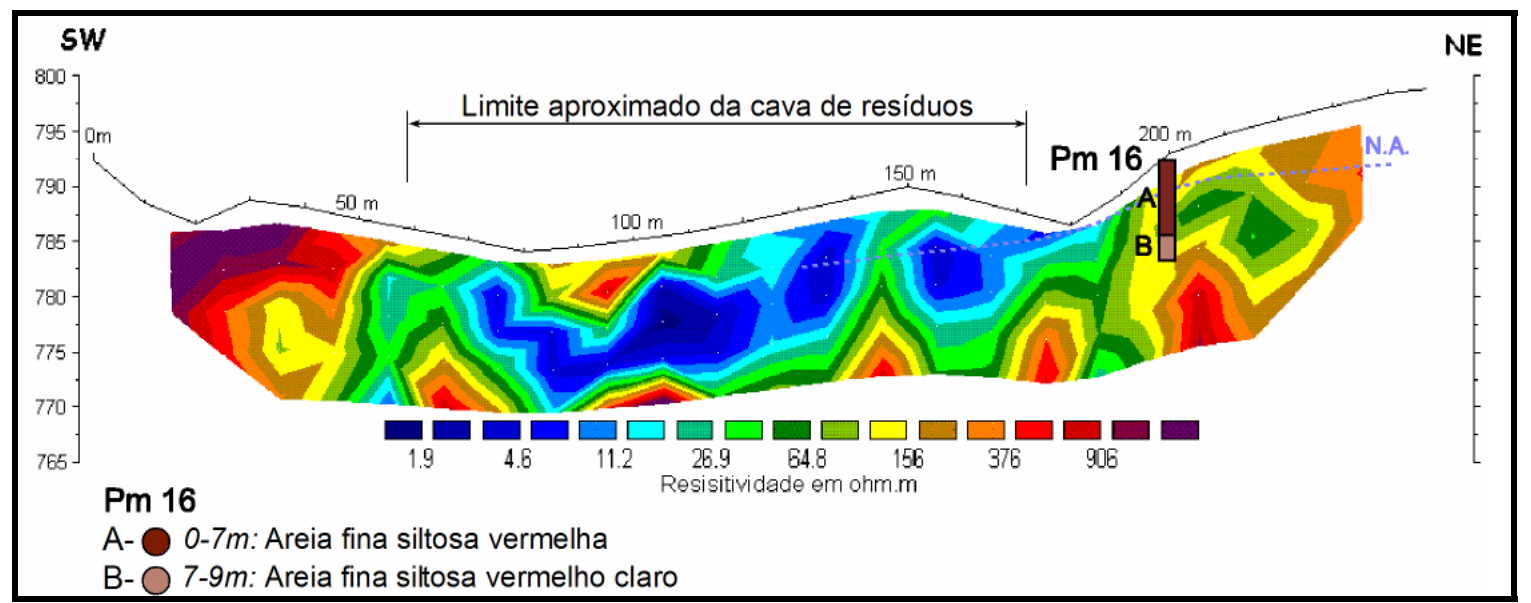

Figura 34: Seção de resistividade (RES2DINV) da linha 4, nível d'água medido e dados da composição dos poços (Freitas, 1995 e Álvares 2000).

$\mathrm{Na}$ seção de cargabilidade da linha 4 (Figura 35) podem ser observados os valores de alta cargabilidade concentrados nas regiões correspondentes a da cava de resíduos. As anomalias de cargabilidade ocorrem de forma localizada dentro dos resíduos, refletindo a sua heterogeneidade.

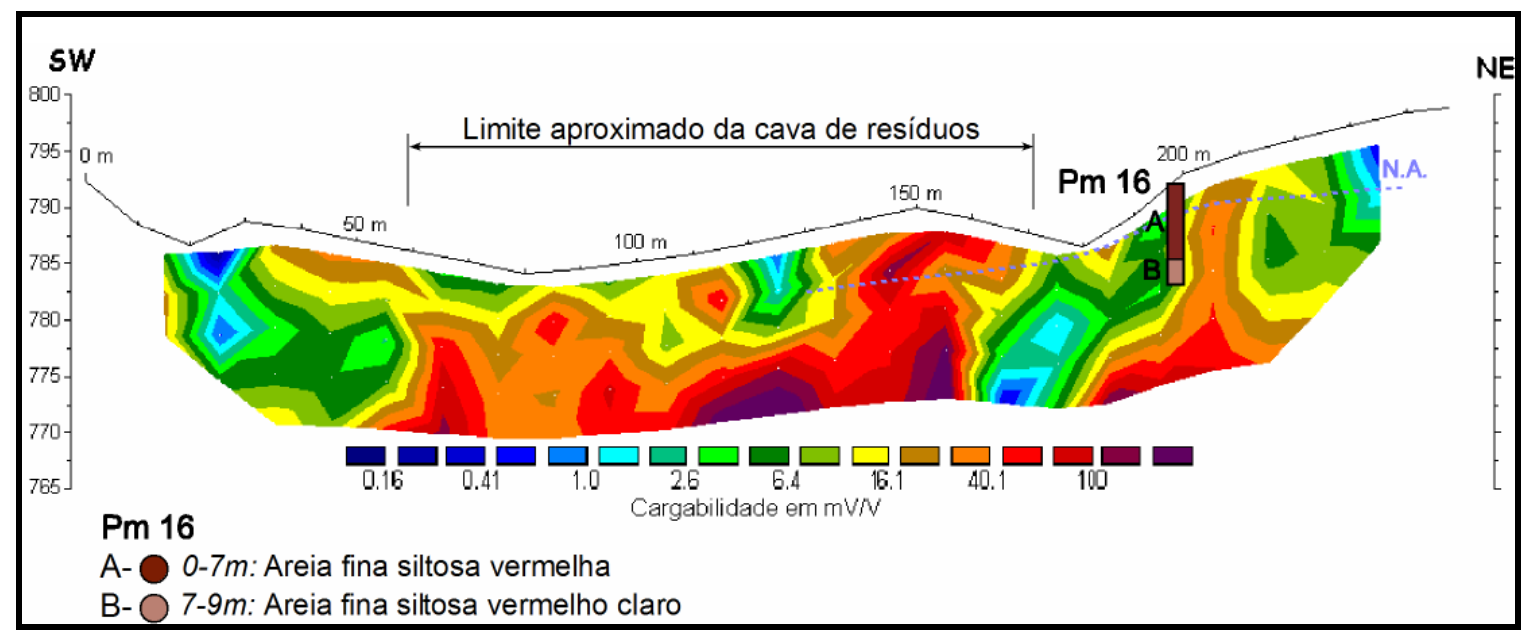

Figura 35: Seção de cargabilidade (RES2DINV) da linha 4, nível d'água medido e dados da composição dos poços (Freitas, 1995 e Álvares 2000). 


\subsubsection{Linha 5}

Na seção de resistividade da linha 5, conjuntamente com o posicionamento e composição dos poços que ela intercepta (Figura 36), observa-se a correspondência da localização dos baixos valores de resistividade com a dos resíduos e percolados encontrados no poço 33, e pode-se perceber também que um eventual espalhamento lateral a linha (SW-NW), não é efetivo, visto os valores mais altos de resistividade encontrados nessas porções.

Na seção de cargabilidade da linha 5 (Figura 37), pode-se constatar, mais uma vez, que os maiores valores de cargabilidade encontram-se em zonas correspondentes as de menor resistividade, ou seja, na porção preencida por resíduos e influenciada pelos percolados.

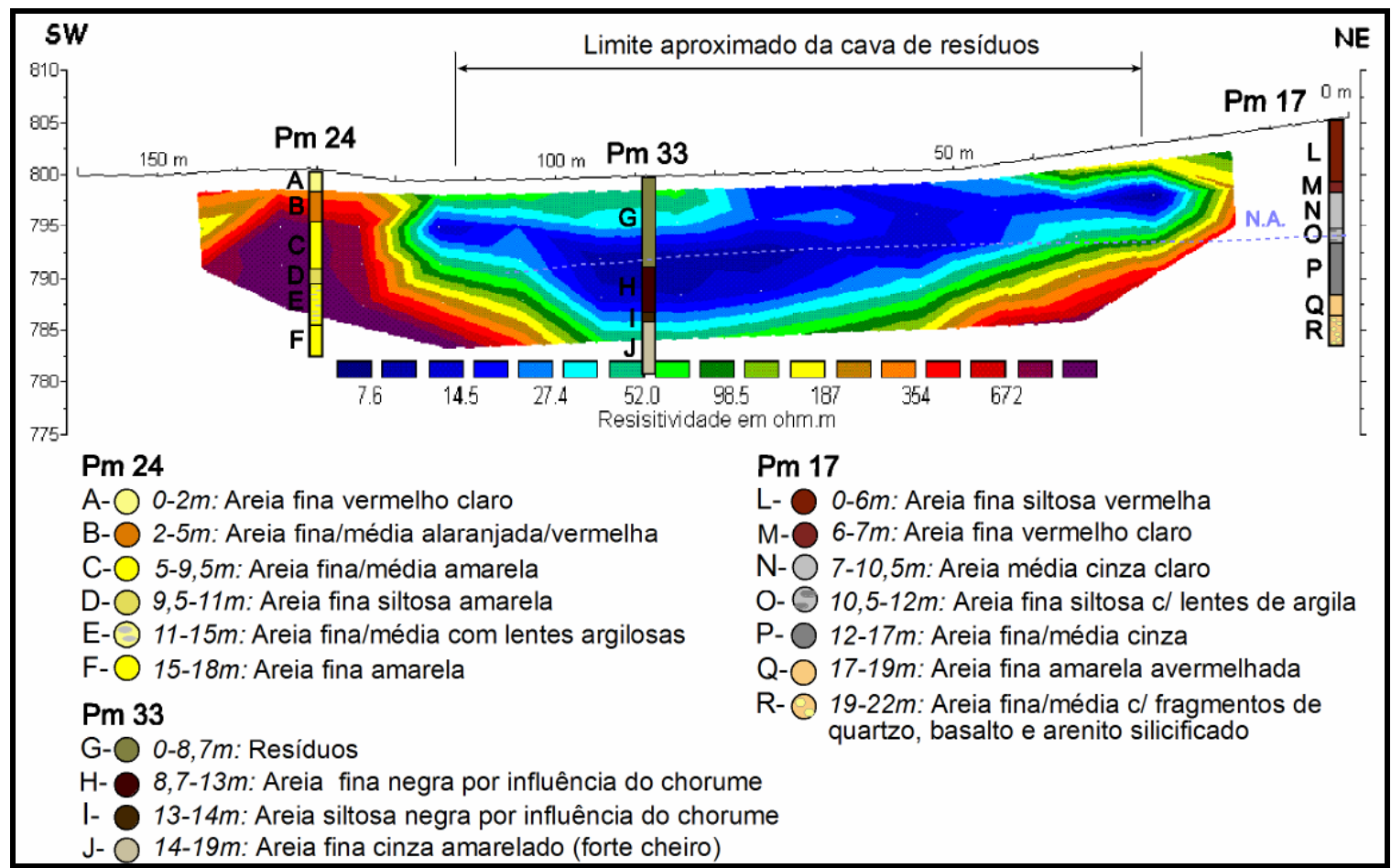

Figura 36: Seção de resistividade (RES2DINV) da linha 5, nível d'água medido e dados da composição dos poços (Freitas, 1995 e Álvares 2000). 


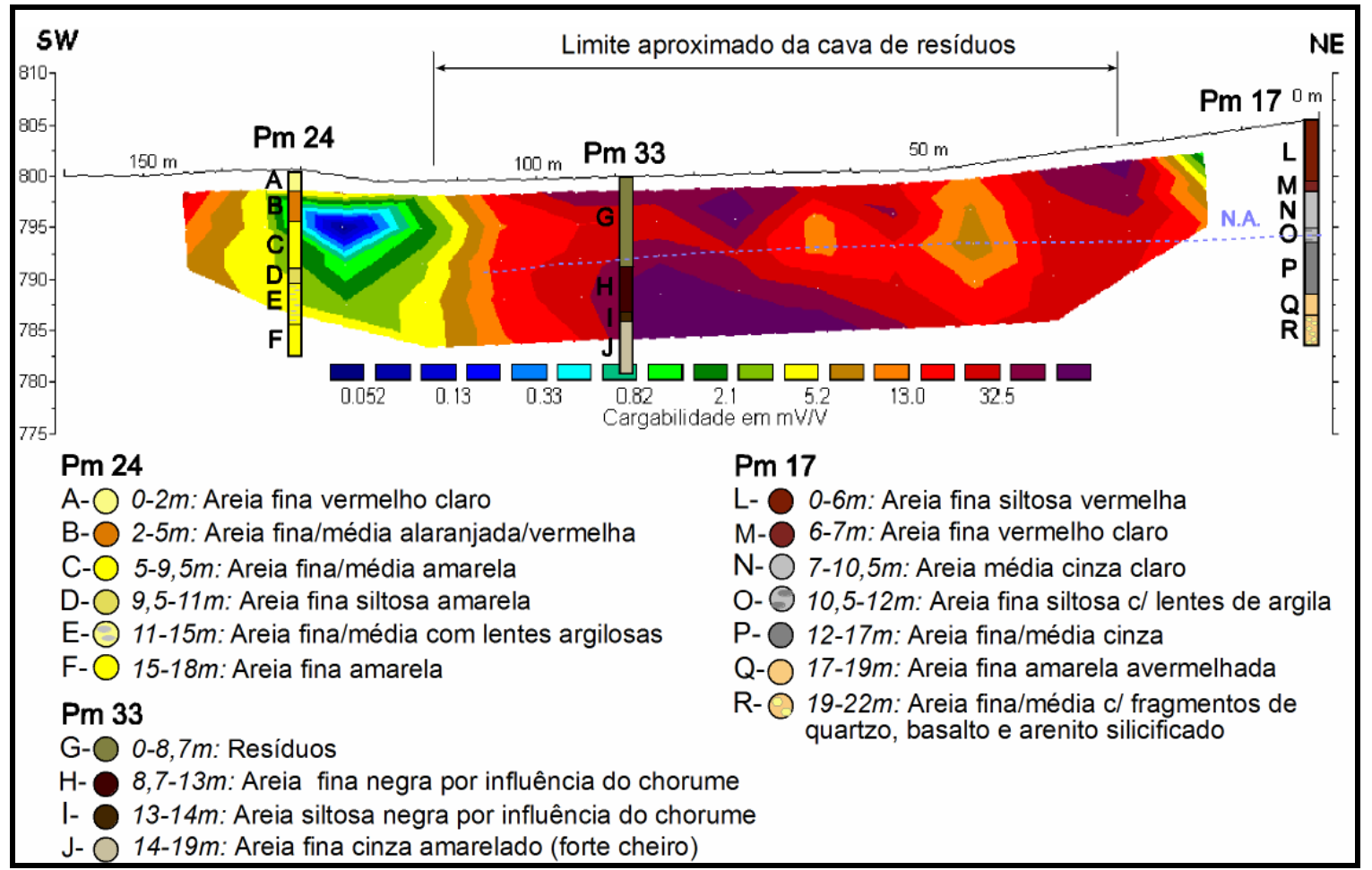

Figura 37: Seção de cargabilidade (RES2DINV) da linha 5, nível d'água medido e dados da composição dos poços (Freitas, 1995 e Álvares 2000).

\subsection{Análise da evolução da contaminação no período de 1995 a 2005}

Para análise da evolução da contaminação, causada pela instalação inadequada do lixão de São Carlos, comparou-se os dados obtidos com os caminhamentos elétricos realizados em 1995 com os realizados em 2005 (Anexo I).

Pode-se perceber que embora os valores de resistividade encontrados em 1995 sejam um pouco mais baixos que os de 2005 , em parâmetros de valores que indicam contaminação (pelo menos até $150 \mathrm{ohm} . \mathrm{m}$ ) percebe-se que a situação não é muito diferente.

Analisando verticalmente as linhas percebe-se que antes já existia contaminação e hoje continua ocorrendo, praticamente nas mesmas proporções, como pode ser observado na comparação das linhas 5 de 1995 e 3 de 2005 (Anexo II). Este mesmo comportamento pode ser observado comparando a linha 2 de 2005 com a linha 6 de 1995 e a linha 5 de 2005 com a 4 de 1995, também apresentadas no Anexo II.

A direção de fluxo SW-NE sugerida anteriormente por outros autores, como Gadotti (1997) e Matsuzaki (1998) não foi evidenciada pelas seções geofísicas 
produzidas, mas pode estar associada a presença de uma descontinuidade mapeada por Muro (2000) como uma falha normal, que apresenta essa mesmo sentido SW-NE (Figura 38).

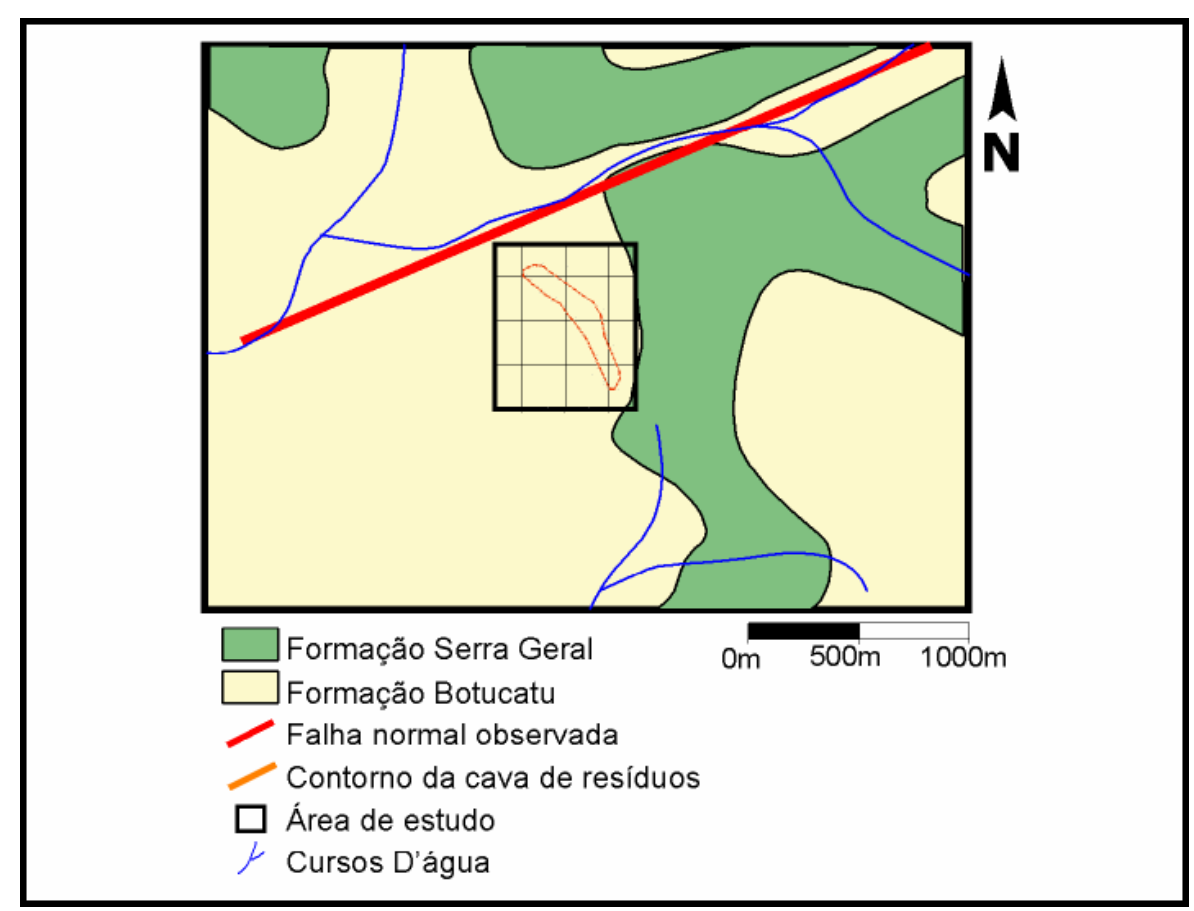

Figura 38: Geologia conforme Muro (2000), com a localização da área de estudo em relação a falha por ele observada.

Observando os perfis de cargabilidade percebe-se nas linhas $1,2,3,4$ e 5 de 2005 (Anexo II) uma anomalia no sentido vertical, que quando analisada conjuntamente com o perfil topográfico da região, anterior a instalação do lixão, correspondem a porção onde encontrava-se instalada a voçoroca, que evoluiu a partir de uma simples erosão até atingir o nível de base. Esse nivel de base poderia ser o nível regional, ou como sugere Álvares (2000), poderia ser relativo a um aquifero suspenso, sustentado por sedimentos siltosos argilosos confinantes.

$\mathrm{Na}$ figura 39 foram podem ser visualisadas as seções de resistividade e na Figura 40 as seções de cargabilidade, ambas obtidas no RES2DINV e plotadas conjuntamente com o mapa topográfico da área (Álvares, 2000), de maneira a permitir uma visualização espacial da disposição das linhas, bem como do alinhamento das anomalias de baixa resistividade e alta cargabilidade. 


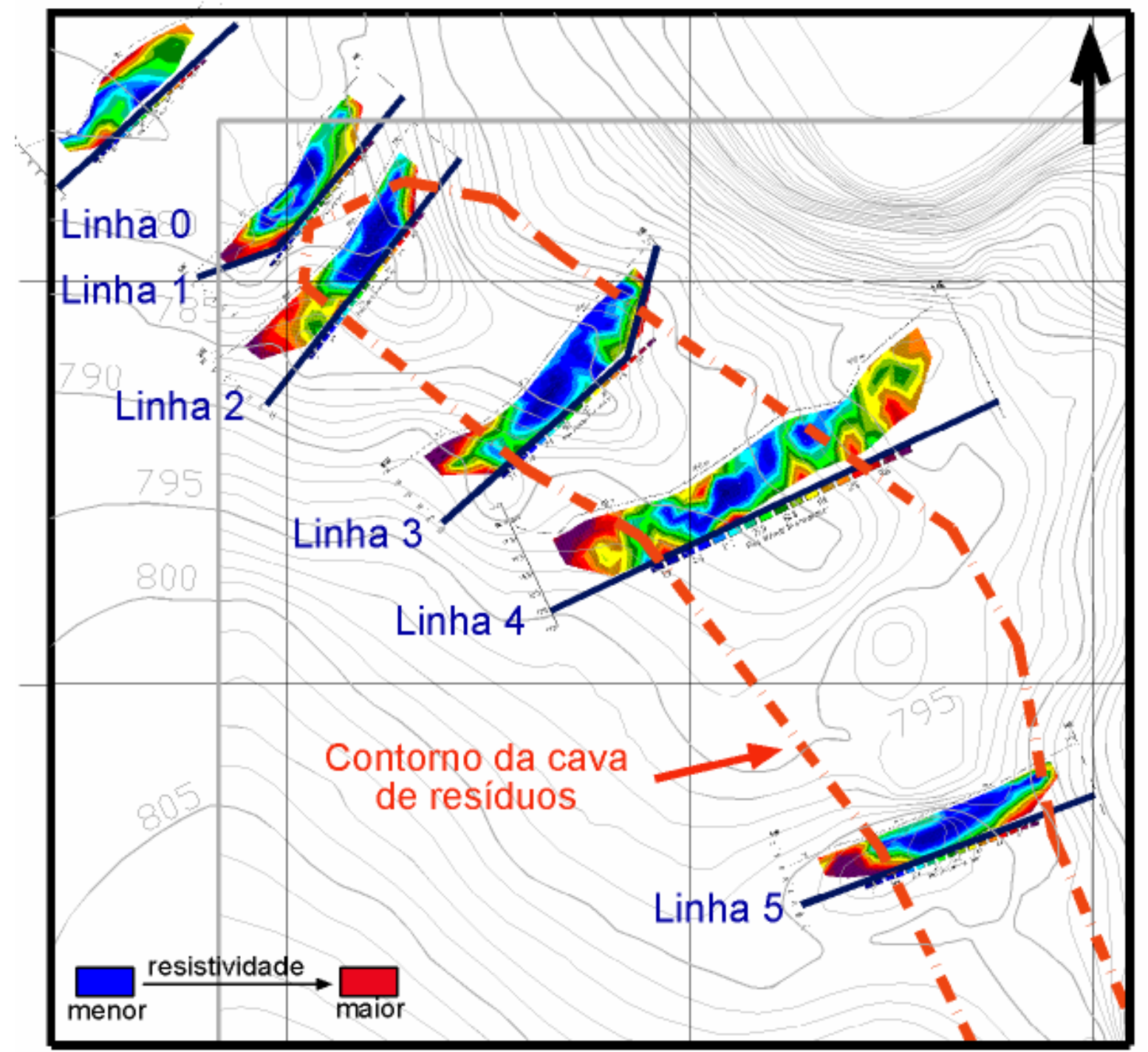

Figura 39: Seções de resistividade de 2005 dispostas espacialmente com o contorno da cava de resíduos (as escalas de cores em cada seção são diferentes, para visualização das escalas individuais de cada seção observar as figuras $26,28,30,32,34$ e 36).

Quando se comparam os perfis de resistividade e os de cargabilidade observase que a anomalia de alta cargabilidade coincide com a zona onde encontram-se os valores de menor resistividade, indicando que pode haver uma contaminação em profundidade, com os contaminantes infiltrando por uma descontinuidade nessa região. Isso pode ser observado, por exemplo, nas seções de resistividade da linha 6 de 1995, 2 de 2005 e na seção de cargabilidade da linha 2 de 2005 (Anexo I). 


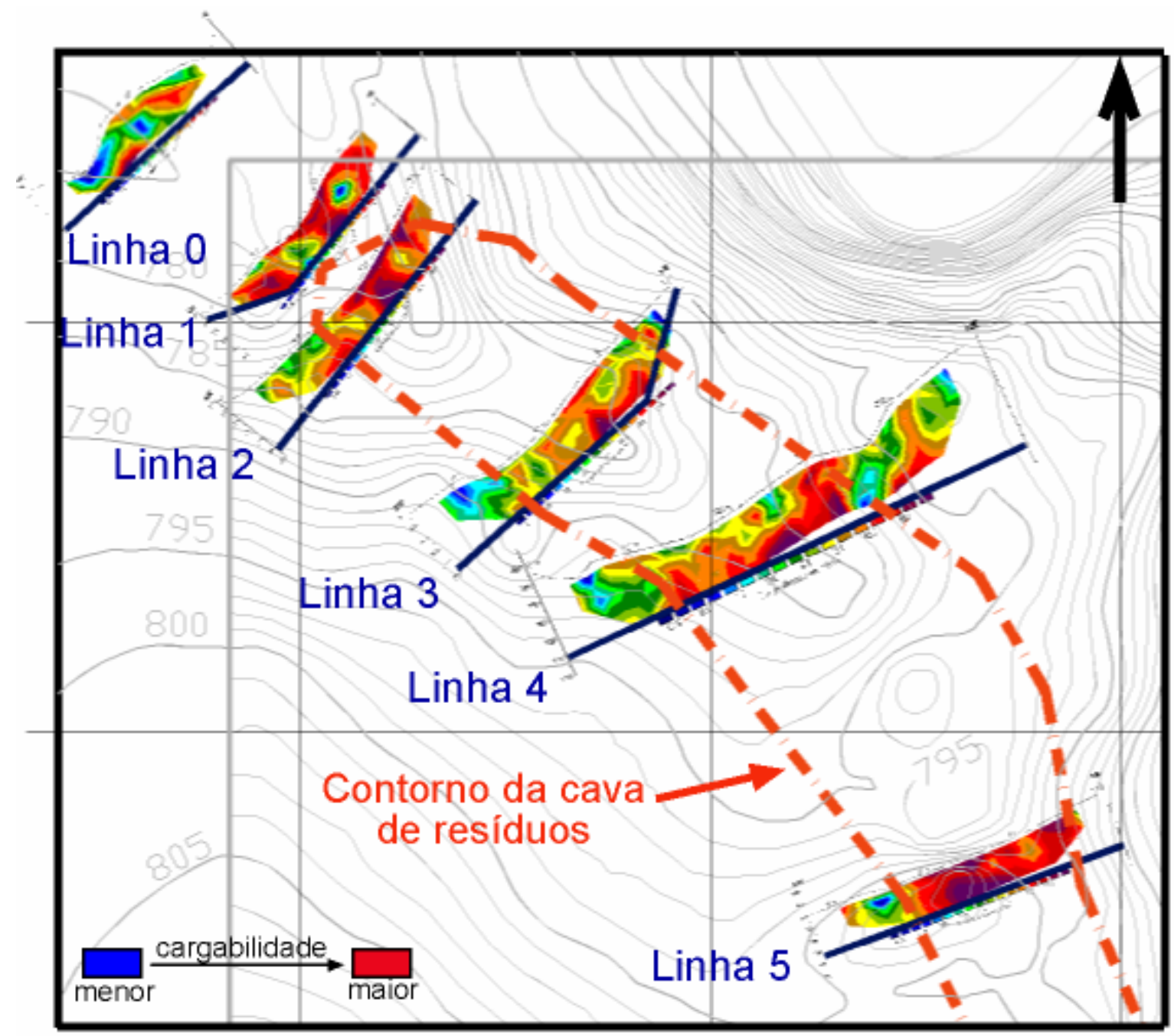

Figura 40: Seções de cargabilidade 2005 dispostas espacialmente com o contorno da cava de resíduos (as escalas de cores em cada seção são diferentes, para visualização das escalas individuais de cada seção observar as figuras 27, 29, 31, 33, 35 e 37).

Analisando as fotos aéreas da região de 1962 e 1971 (Figuras 41 e 42 respectivamente), e comparando-as com as de 2000 (Figura 43), podemos observar a mudança do relevo, devido principalmente a atividades antrópicas. 


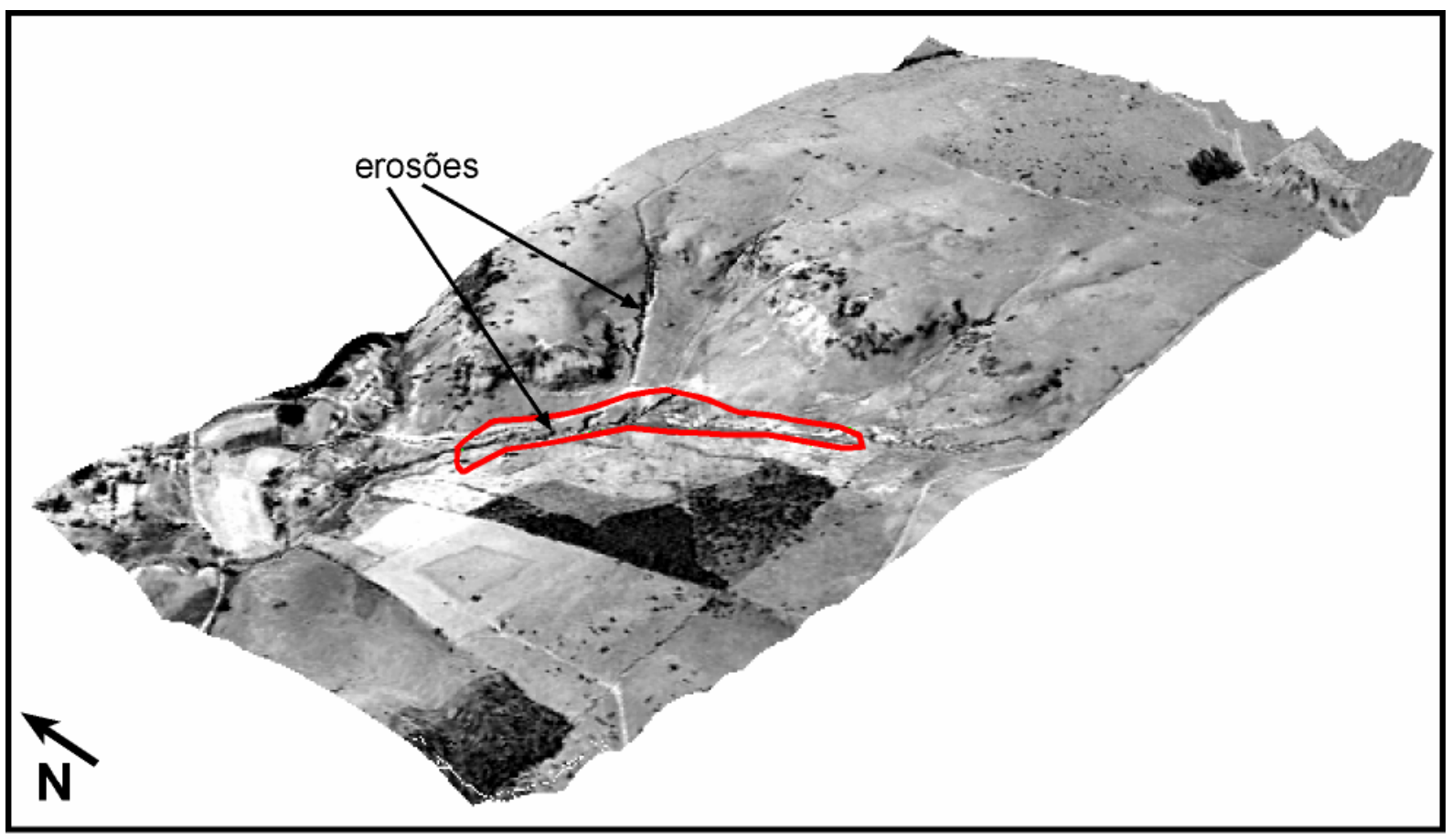

Figura 41: Modelo digital do terreno com sobreposição da foto aérea ( $1: 25.000)$ da área de estudo em 1962, com indicação do contorno da cava de resíduos que seria posteriormente instalada.

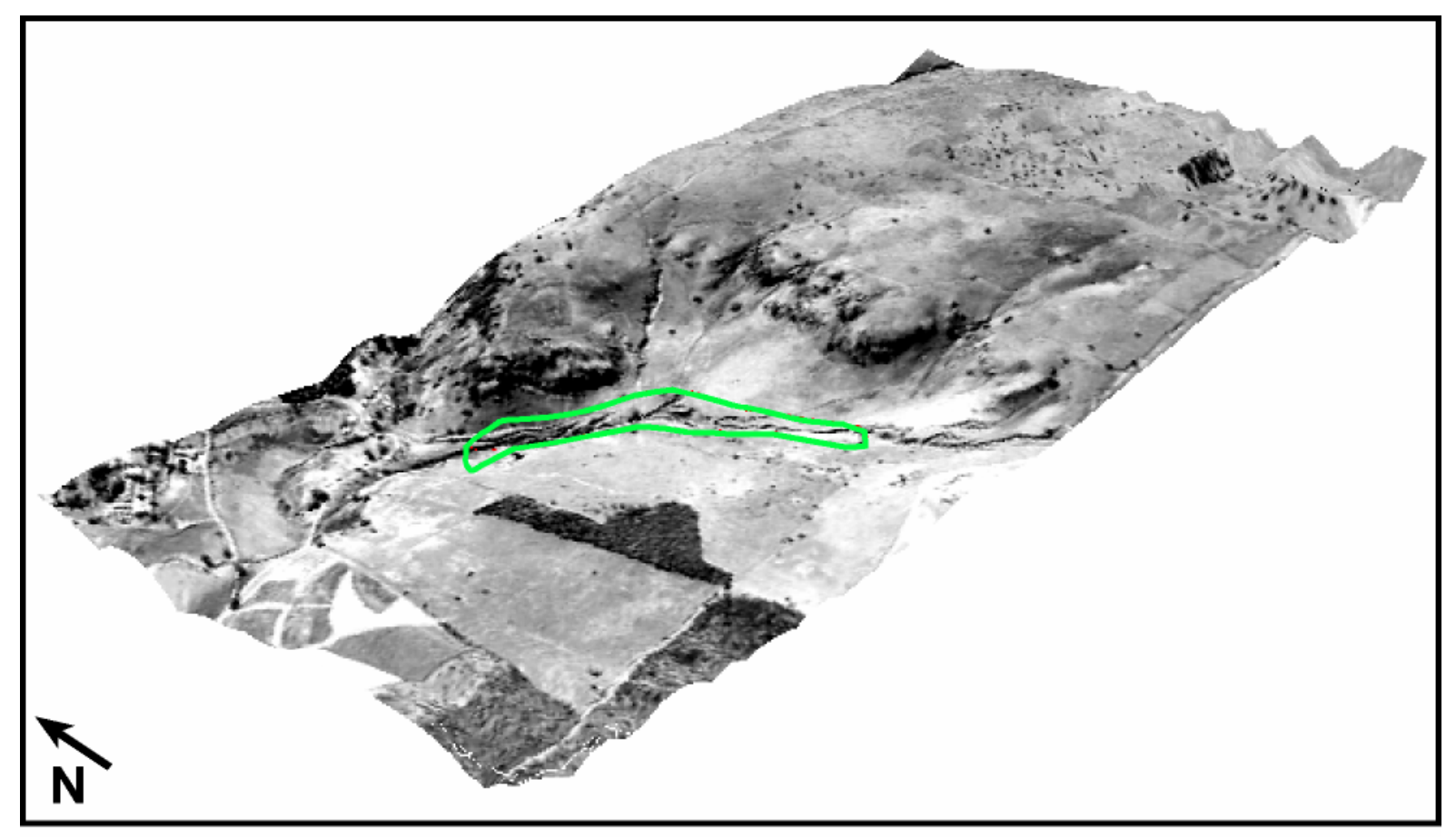

Figura 42: Modelo digital do terreno com sobreposição da foto aérea ( $1: 25.000)$ da área de estudo em 1971, com indicação do contorno da cava de resíduos que seria posteriormente instalada. 


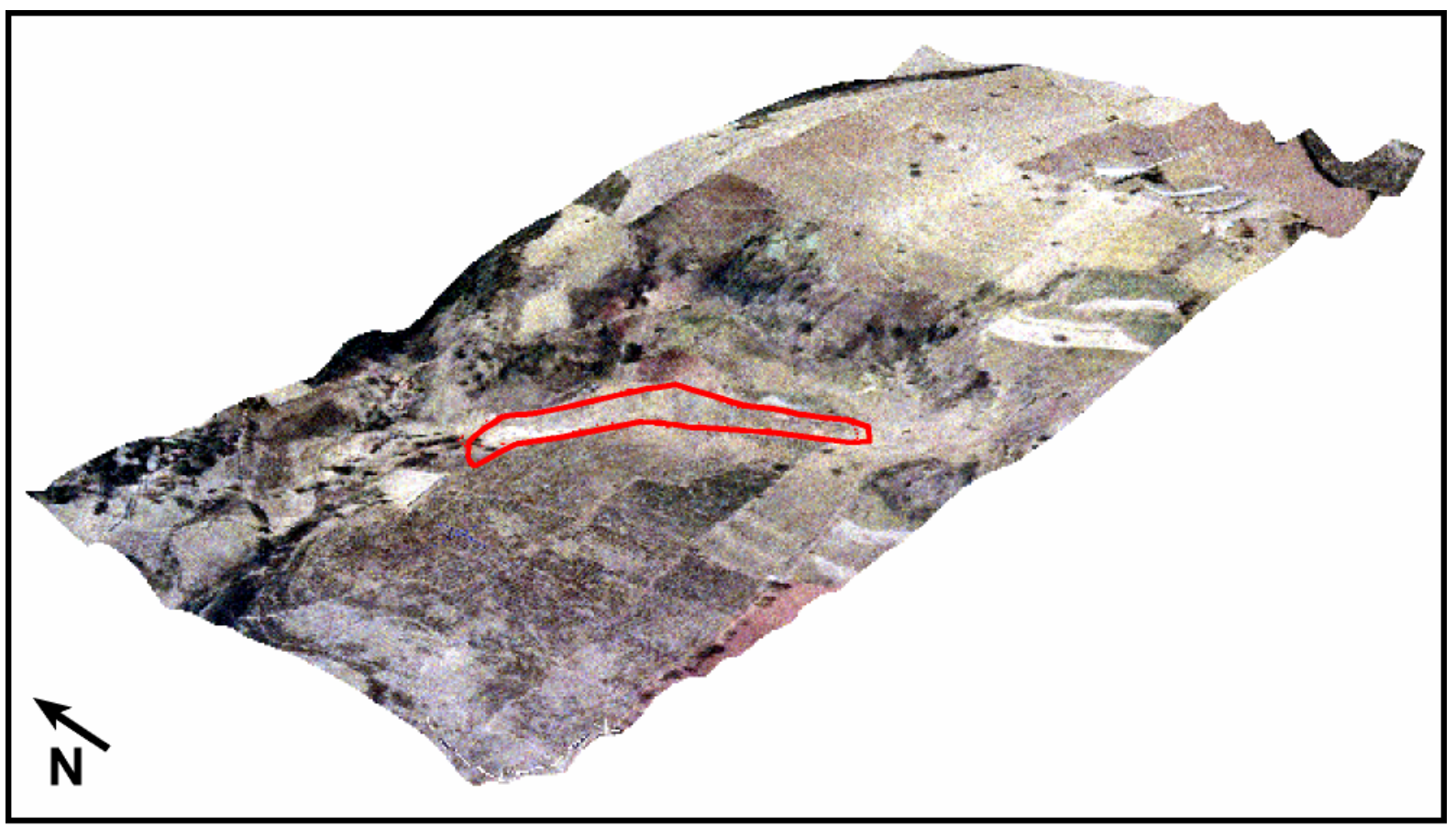

Figura 43: Modelo digital do terreno com sobreposição da foto aérea (1:30.000) da área de estudo em 2000, com indicação do contorno da cava de resíduos.

Para confirmar a possibilidade da existência de uma descontinuidade nessa região resolveu-se analisar com maior detalhe as fotos aéreas dessa área, além de retornar ao campo em busca de indícios.

Nos afloramentos de campo não foi possivel identificar evidências que caracterizem essa descontinuidade, mas analisando as fotos percebe-se uma quebra de relevo marcante nessa porção, separarando um relevo mais íngreme na porção leste de um relevo mais plano na porção oeste da descontinuidade.

Analisando regionalmente a área, em uma imagem de satélite, percebe-se evidência dessa descontinuidade de maneira regional, como pode ser observado na Figura 44. 


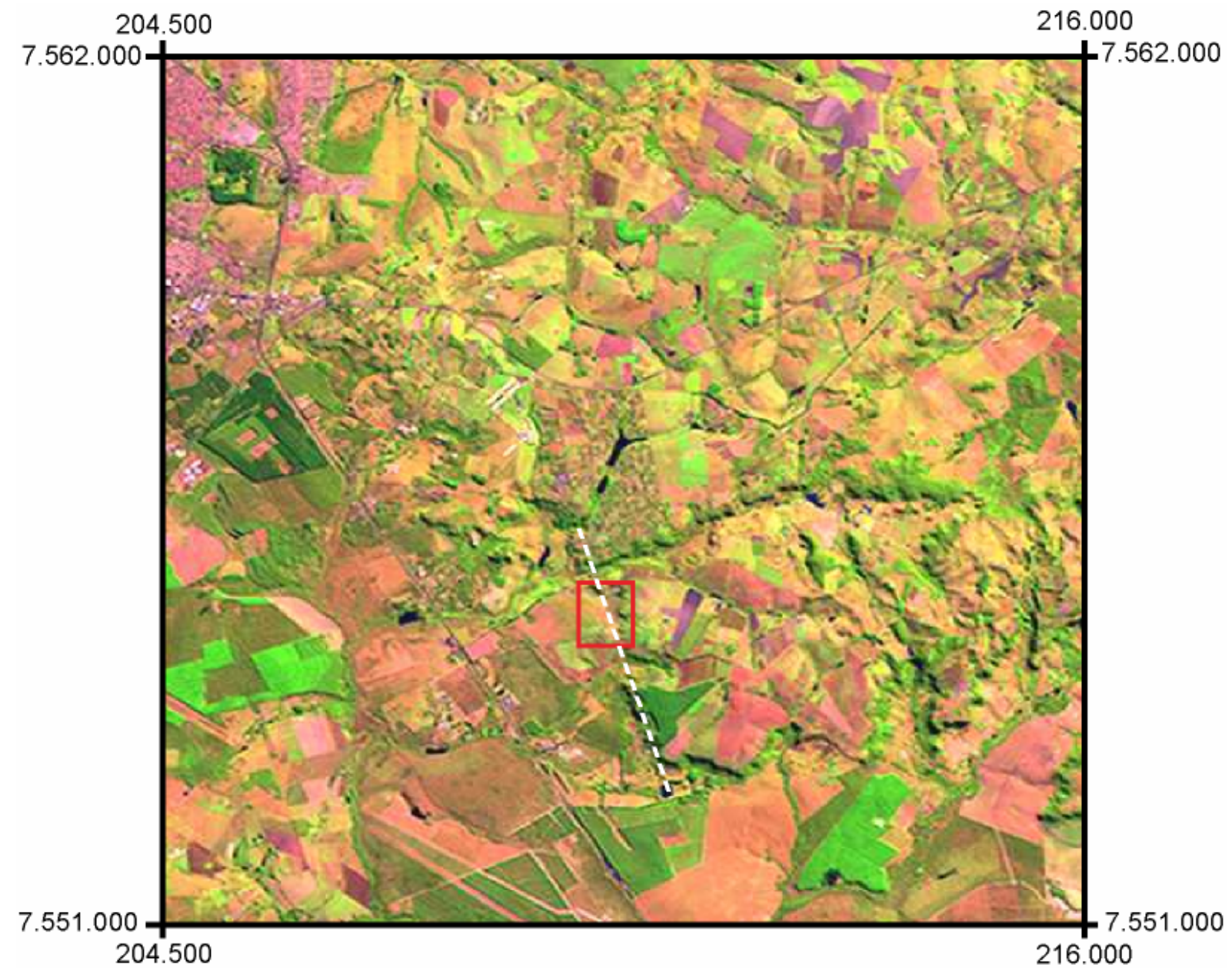

Figura 44: Localização da área de estudo, com indicação da descontinuidade em imagem de satélite (Imagem Landsat 7 - Miranda, 2001).

Isso dá indicações de que pode estar ocorrendo contaminação em maior profundidade como já sugerido anteriormente por Gonçalves et al. (1992). Essa contaminação de zonas mais profundas estaria associada a essa descontinuidade penetrante sob o corpo do lixo, provavelmente sobre a qual a antiga voçoroca instalou-se.

Outro fator que favorece a percolação do chorume é a variação sazonal do nível d’água. As leituras do nível d’água foram realizadas em maio/2005, e quando comparadas com as obtidas por Álvares (2000), medidas em julho, observa-se que estas encontram-se, em média, $50 \mathrm{~cm}$ abaixo. Os valores de nível d'água medidos por Freitas (1996) encontram-se ainda inferiores, cerca de $70 \mathrm{~cm}$, no entanto não foi possível obter o período em que realizou-se esta leitura.

Para análise espacial da contaminação decidiu-se traçar um perfil longitudinal ao corpo do lixo, a localização desse perfil pode ser observado na Figura 45, e o perfil na Figura 46. 


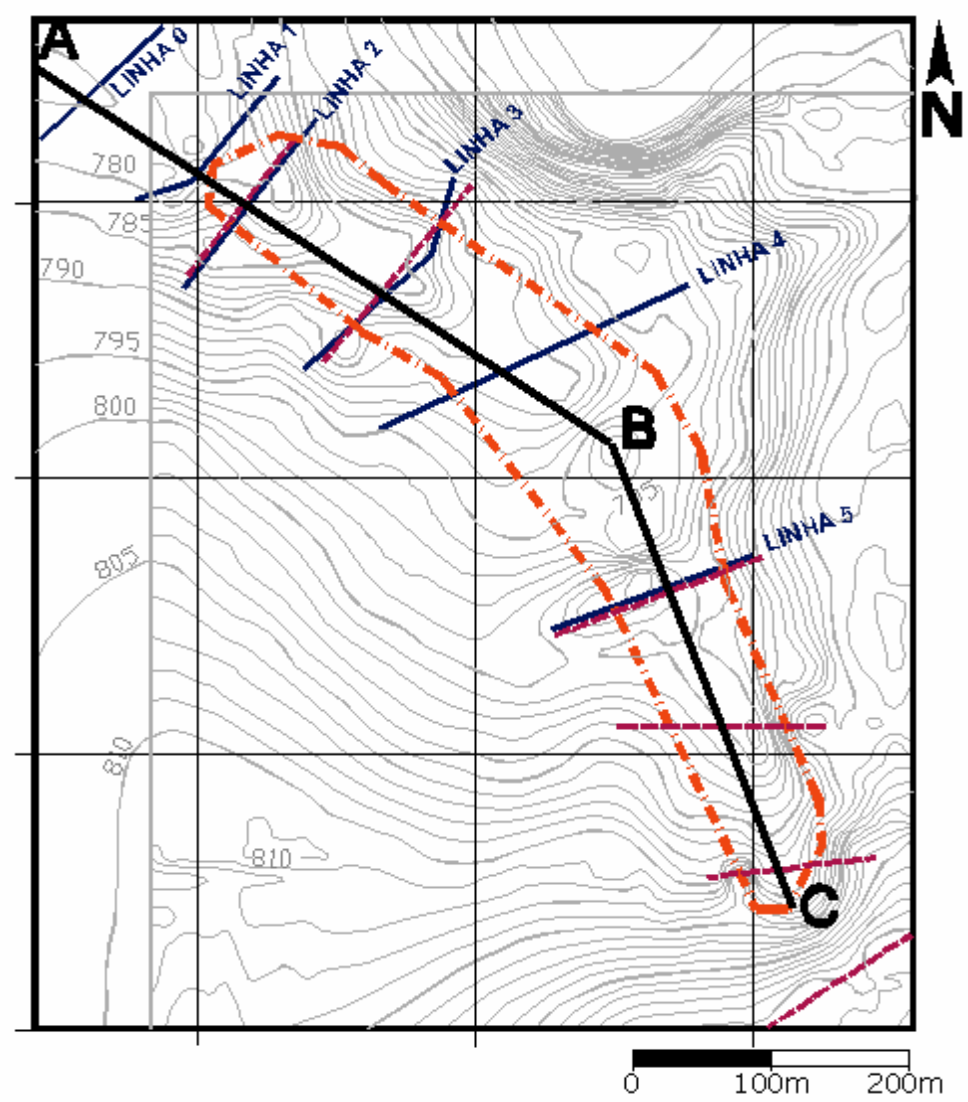

Figura 45: Localização do perfil ABC, que corta o corpo do lixo em toda sua extensão.

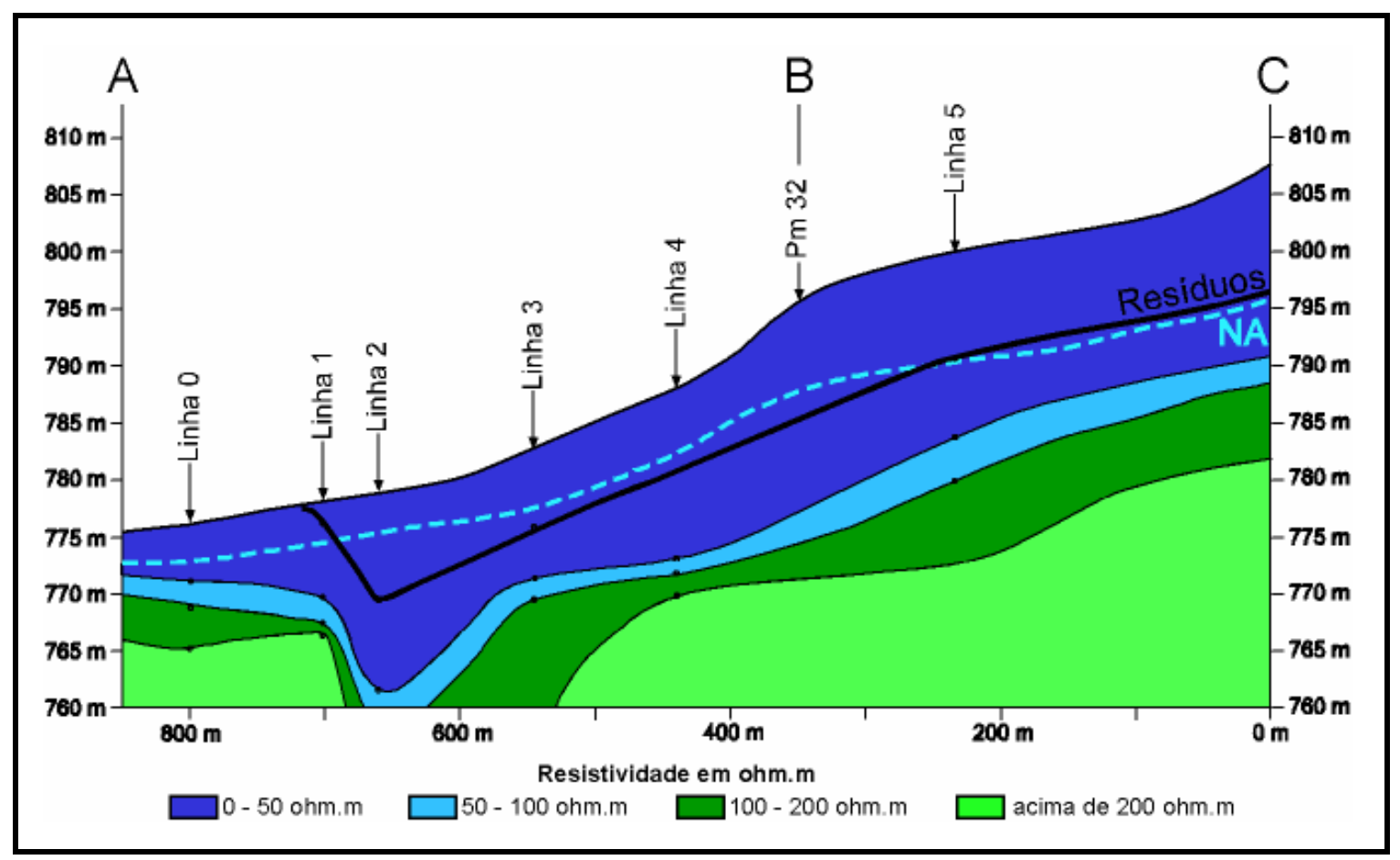

Figura 46: Perfil ABC, que corta o corpo do lixo em toda sua extensão. 
Observando esse perfil pode-se perceber que na porção do perfil cortado pela linha 2 de eletrorresistividade é a região que apresenta resisitividade mais baixa em regiões mais profundas, isso se deve, principalmente, ao fato da grande espessura de resíduos depositados nessa região.

Também se nota que grande parte dos resíduos está depositado abaixo do nível d’água, propiciando a contaminação das águas subterrâneas.

Quando se analisa esse perfil (Figura 46) em conjunto com a Figura 39, onde estão plotadas as seções de resistividade, percebe-se que o sentido prefencial do fluxo concentra-se na direção NW.

Ao comparar-se a Figura 39, que apresenta os dados de resistividade de 2005, com a 47, com os dados de 1995, nota-se que a distribuição da contaminação não encontra-se muito diferente da situação de 10 anos atrás.

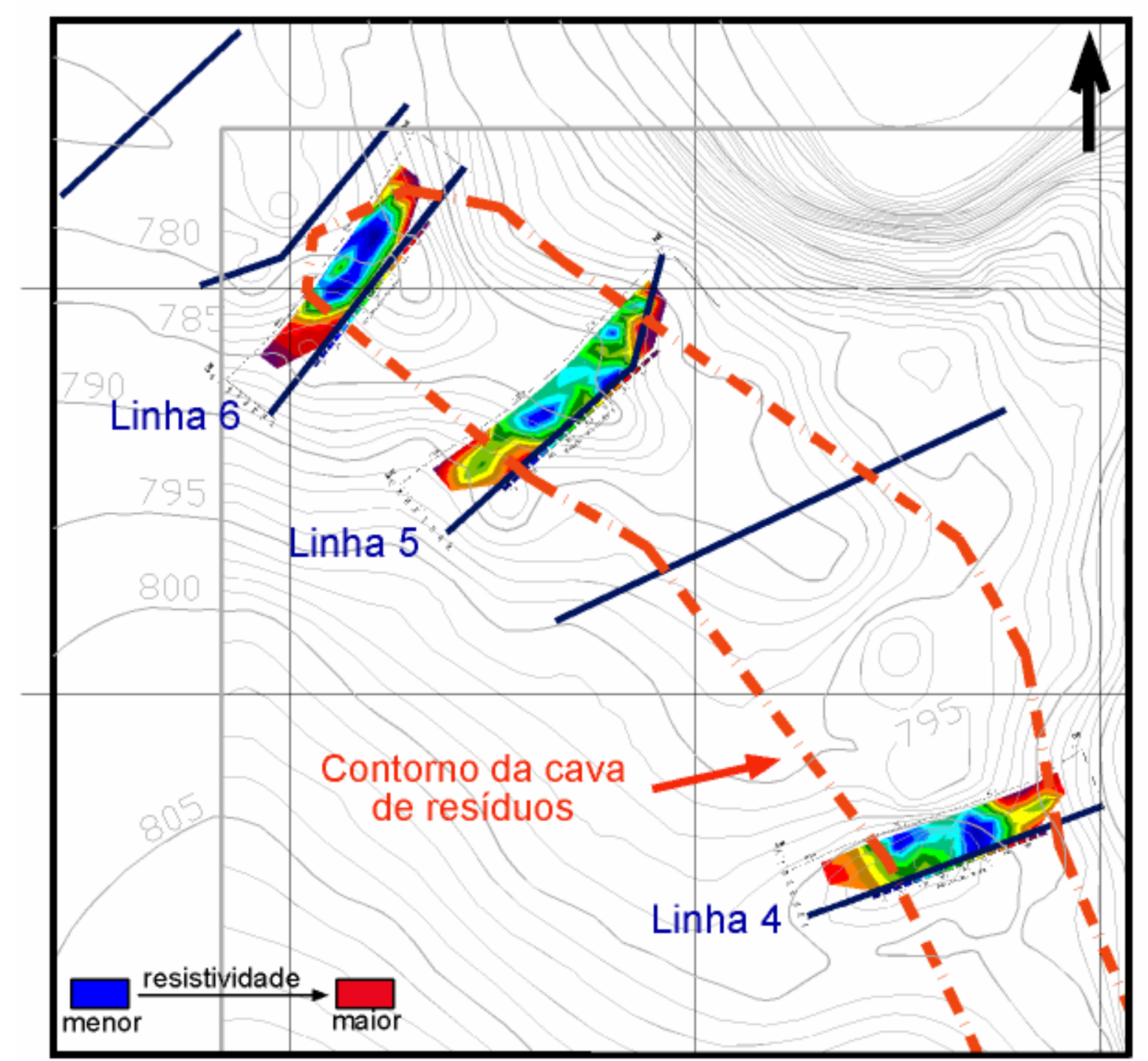

Figura 47: Seções de resistividade de 1995 dispostas espacialmente com o contorno da cava de resíduos. 
Nos mapas de resistividade produzidos no Surfer 8.0 , com profundidades aparentes de 10, 20 e 30 metros, exibidos na Figura 48, a anomalia condutora pode ser interpretada como uma frente de contaminação desenvolvendo-se a partir dos resíduos e caminhando no sentido NW, seguindo o fluxo subsuperficial, sendo que isso é melhor observado no mapa de profundidade aparente de 20 metros. Nestes mapas pode-se notar que em profundidade ocorre também um suave espalhamento da pluma de contaminação.

Nessa figura também são expostos os valores de resistividade aparente em ohm.m correlacionados com a concentração de sólidos totais dissolvidos (TDS) em $\mathrm{mg} / \mathrm{l}$, conforme Equação 1, proposta por Meju (2000), onde o $\sigma_{W}$ é a condutividade elétrica da solução aquosa em $\mathrm{mS} / \mathrm{m}$ e $\sigma_{W}=1000 /$ resistividade em ohm.m.

$$
\operatorname{TDS}=-54,4+7,04 \sigma_{W}
$$

Os valores de TDS obtidos evidenciam níveis de contaminação elevada sob o corpo do lixo, sendo que até a profundidade aparente de 20 metros podem ser observados valores da ordem de $600 \mathrm{mg} / \mathrm{l}$. Em níveis mais profundos (30 metros) a concentração de sólidos dissolvidos não atinge concentrações tão altas, apresenta no máximo valores da ordem de $200 \mathrm{mg} / \mathrm{l}$, no entanto pode-se perceber uma continuidade lateral dessa ordem de valores.

Deve-se resaltar que esses valores de sólidos totais dissolvidos podem, neste caso, corresponderem a valores substimados nas porções de solo e superestimados nas porções de lixo, já que nesta equação os valores de condutividade elétrica são em solução aquosa. 


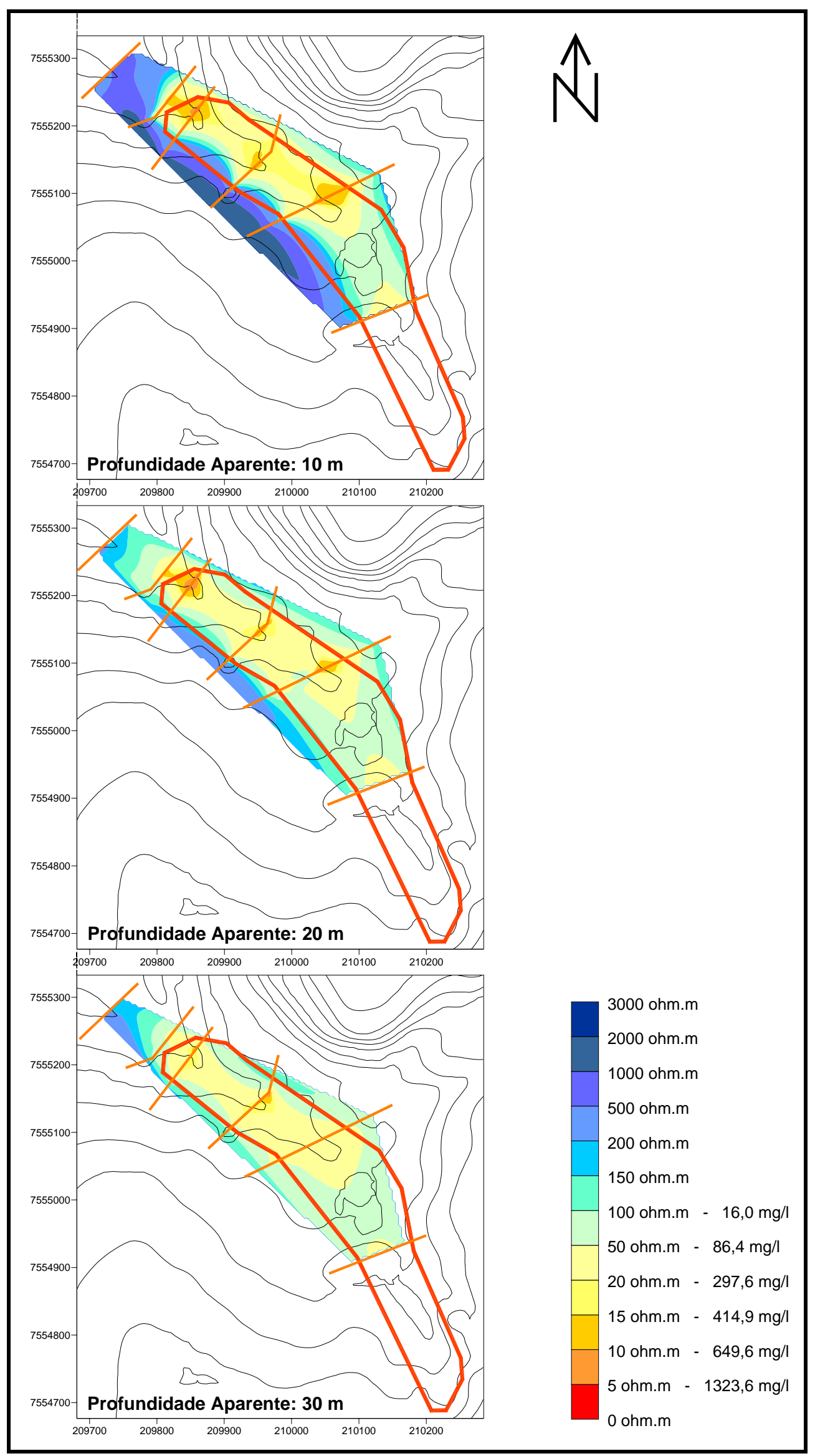

Figura 48: Mapas de resistividade aparente das profundidades de 10, 20 e 30 metros. 
Esse fluxo de contaminantes, de direção NW, é facilitado pelo meio de alta permeabilidade dos materiais arenosos da região, que nos ensaios de granulometria conjunta executados mostraram-se predominantemente areias finas a médias, esses resultados são compatíveis com os encontrados por Freitas (1996), que também realizou esses ensaios, mas em pontos distintos.

Como pode ser constatado nos ensaios de infiltração, a permeabilidade na área encontra-se na faixa de $10^{-5} \mathrm{~m} / \mathrm{s}$, sendo que isto pode variar pontualmente, principalmente sobre o corpo do lixo, de composição muito heteregênea.

Freitas (1996), a partir de testes de bombeamento, caracterizou o aquífero na região de estudo como de comportamento heterogêneo (transmissividade) e anisotrópico (condutividade hidráulica), mas ressaltou a facilidade com que ocorre o fluxo subterrâneo e o deslocamento da pluma de poluentes.

Outro fator que facilita a percolação é a ausência de barreiras menos permeáveis, que quando existem são de argilas pouco ativas a inativas, como constatado pelos ensaios de adsorção de azul de metileno empregados, sendo que essas eventuais camadas argilosas ou sílticas são de reduzida espessura, como foi observado em campo, durante a execução da tradagem para obtenção de amostras para o ensaio de infiltração.

Esses dados são compatíveis com os encontrados nos estudos de Meneses (1995) e Freitas (1996), que determinaram os solos da área como de baixa capacidade de troca catiônica, ou seja, com baixa capacidade de retenção de contaminantes.

Já Álvares (2000) sugere que o corpo do lixo poderia estar assentado sobre um acamamento areno siltoso, que possobilitaria uma proteção ao risco de contaminação do aquífero profundo, sugerindo transporte superficial advectivo de contaminates superior ao de subsuperfície. Com os estudos desenvolvidos nesta pesquisa não foi observada a presença ou influência dessas possíveis zonas protetoras do aquífero profundo. 


\section{Conclusões}

Como a alteração da qualidade da água subterrânea é de extrema importância para a população atual e futura, esse trabalho mostrou-se de grande valia, já que a área de estudo trata-se de um lixão instalado sobre a Formação Botucatu, detentora do maior manancial brasileiro de águas subterrâneas.

O objetivo de caracterização geológico-geotécnica, associada a aplicação de métodos geoelétricos, foi alcançado, sendo que após a análise dos dados gerados conjuntamente com os ensaios e pesquisas de estudos anteriores, constatou-se que na área do lixão o aqüífero apresenta-se livre e sua contaminação pôde ser confirmada até aproximadamente 25 metros de profundidade.

Como foram aplicados no caminhamento geofísico as técnicas de resistividade e polarização induzida, foram produzidas seções com diferentes parâmetros (resistividade e cargabilidade), que se complementaram.

As zonas contaminadas puderam ser melhor definidas nas seções de resistividade, sendo os dados de cargabilidade utilizados de maneira auxiliar. No entanto, ambas comprovaram a boa aplicabilidade do caminhamento elétrico para visualização de contrastes entre áreas contaminadas e não contaminadas, com continuidade lateral dos resultados.

Pôde-se constatar uma boa aderência entre os dados geofísicos e os reais, já que os valores de baixa resistividade coincidem com as porções onde foram encontados resíduos ou chorume nas amostras coletadas durante a execução dos poços por Freitas (1996).

Há indicações de que pode estar ocorrendo contaminação do aqüífero profundo, ao contrário do que sugeriram anteriormente alguns autores. Essa contaminação de 
zonas mais profundas estaria associada a uma possível descontinuidade geológica sob o corpo do lixo.

Associado a estes fatores tem-se como agravante a alta permeabilidade dos materiais arenosos da região, que é da ordem de $10^{-5} \mathrm{~m} / \mathrm{s}$, a ausência de barreiras menos permeáveis, que quando existem são de argilas pouco ativas a inativas e a variação sazonal do nível d'água, facilitando o fluxo dos contaminantes.

Essa contaminação das águas subterrâneas estaria ocorrendo através da percolação de águas pluviais e outros líquidos gerados pela própria degradação dos resíduos, que por infiltração atingem o nível d'água, compondo a pluma de contaminação, que em algumas porções apresenta concentrações elevadas de sólidos dissolvidos, da ordem de $600 \mathrm{mg} / \mathrm{l}$. Essa pluma apresenta fluxo preferência para NW, seguindo o sentido do fluxo do escoamento superficial.

Também se percebe que a infiltração de água no corpo do lixo se dá de maneira semelhante a medida no solo, embora no corpo do lixo possam ser encontradas maiores variações, devido a sua composição heterogênea.

Quanto a evolução da contaminação, pode-se perceber que em 1995 já existia contaminação e que hoje continua ocorrendo, praticamente nas mesmas proporções até a profundidade investigada, isso é confirmado pelas seções geofísicas de 1995 e 2005, e pelos dados dos poços.

Para trabalhos futuros na área, sugere-se que a investigação alcance maiores profundidades, de maneira a constatar efetivamente a contaminação do aquífero profundo; além de estudos químicos e geoquímicos baseados em coletas de amostras de água subterrânea e supercifical, de maneira a caracterizar os contaminantes presentes. 


\section{Referências Bibliográficas}

ABNT - ASSOCIAÇÃO BRASILEIRA DE NORMAS TÉCNICAS (1993) - NBR 9896 Glossário de poluição das águas. Rio de Janeiro.

ABNT - ASSOCIAÇÃO BRASILEIRA DE NORMAS TÉCNICAS (1987) - NBR 10.004 Resíduos sólidos: classificação. São Paulo.

ABNT - ASSOCIAÇÃO BRASILEIRA DE NORMAS TÉCNICAS (1984) - NBR 7.181 AnáliseGranulométrica. Rio de J aneiro.

ACSELRAD, M.V.; AZEVEDO, J.P.S.; MAGALHÃES, P.C. (2004) Uma proposta preliminar de incorporação da água subterrânea ao sistema de gerenciamento e recursos hídricos. In: CONGRESSO BRASILEIRO DE ÁGUAS SUBTERRÂNEAS, 13, 2004, Cuiabá. Anais... Cuiabá: Associação Brasileira de Águas Subterrânea.

AFFONSO, A.O.; MONSORES, A.L.M. (2004) O Conflito conceitual entre águas subterrâneas e águas minerais - uma contribuição jurídica e técnica para uma gestão integrada entre recursos hídricos e minerais. In: CONGRESSO BRASILEIRO DE ÁGUAS SUBTERRÂNEAS, 13, 2004, Cuiabá. Anais... Cuiabá: Associação Brasileira de Águas Subterrânea, 2004.

AGUIAR, A.B.O. (2001) Emprego do Permeâmetro de Guelph na determinação da permeabilidade do solo de camadas de lixo e sua cobertura. 2001. 90 p. Dissertação (Mestrado) - Universidade Federal do Rio de Janeiro. 
ALMEIDA, F.F.M. (1964) Fundamentos Geológicos do Relevo Paulista. Boletim do Instituto Geográfico e Geológico, São Paulo, n. 41, p. 169-263, 1964.

ÁLVARES, C.M.B. (2000) Contribuição ao conhecimento do meio físico da região do lixão de São Carlos - SP, através de estudos geológicos, geofísicos, topográficos e químicos. 158p Dissertação (Mestrado) - Escola de Engenharia de São Carlos, Universidade de São Paulo.

ANA - AGÊNCIA NACIONAL DE ÁGUAS (2004). Informações Hidrogeológicas. Disponível em <www.ana.gov.br/gestaoRecHidricos>. Acesso em 24/nov/04.

ASTM - AMERICAN SOCIETY FOR TESTING AND MATERIALS (1988) - D3385-88 Standard test method for infiltration rate of soils in field using double ring infiltrometers.

AZAMBUJA, E.; COSTA, A.F.U.; NANNI, A.S. (1999) O emprego da prospecção geofísica na avaliação de plumas de contaminação por hidrocarbonetos. Disponível em <http://www.azambuja.com.br/acervo/ REGEO99. pdf >. Acesso em 03/dez/04.

BEAR, J. (1972) Dynamics of fluids in porous media. New York: Dover Publications, 1972, $764 \mathrm{p}$.

BOCANEGRA, E.M.; MARTí NEZ, D.E.; FARENGA, M.O.; CIVIT, E.M. (1998) Modelación del balance hidráulico y del flujo contaminante de um relleno sanitário en mar del Plata, Argentina. In: CONGRESSO LATINO AMERICANO DE HIDROLOGIA SUBTERRÂNEA, 4., 1998, Montevideo. Anais... Montevideo: ALHSUD. p.299311.

BOSSOLAN, N.R.S. (1993) Aspectos ecológicos das populações bacterianas em águas subterrâneas sob efeito de um aterro controlado - São Carlos SP. 120 p. Dissertação (Mestrado) - Centro de Ciências Biológicas da Saúde. Universidade Federal de São Carlos.

BRAGA, A.C.O. (1999) Métodos geoelétricos aplicados. Rio Claro. Apostila... Rio Claro: Universidade Estadual Paulista. 27p. 
BRANCO, S. M. (1991). A água e o homem. In: PORTO, Hidrologia ambiental. Editora da Universidade de São Paulo. Cap. 1, p.14-15.

BRASIL. Constituição (1998). Constituição da Republica Federativa do Brasil. Brasília, DF: Senado, 1998.

BRASIL. Decreto no 24.643, 10 de julho de 1934. Decreta o Código de Águas. Diário Oficial da União, Brasília, DF.

BRASIL. Decreto-Lei no 227, 28 de fevereiro de 1967. Decreta o Código de Minas. Diário Oficial da União, Brasília, DF.

BRASIL. Decreto-Lei no 7.841/45, 8 de agosto de 1945. Decreta o Código Águas Minerais. Diário Oficial da União, Brasília, DF.

BRASIL. Lei no 9.433, 8 de janeiro de 1997. Institui a Política Nacional de Recursos Hídricos e cria o Sistema Nacional de Gerenciamento de Recursos Hídricos. Diário Oficial da União, Brasília, DF.

BUSELLI, G., BARBER, C., DAVIS, G.B.; SALAMA, R.B. (1990). Detection of groundwater contamination near waste disposal sites with transient electromagnetic and electrical methods. Geotechnical and Environmental Geophysics, Oklahoma, v. 2, p. 27-39.

CAETANO-CHANG, M. R. WU, F.T. 1993 A composição faciológica das formações Pirambóia e Botucatu no centro-leste paulista e a delimitação do contato entre as unidades. In: SIMPÓSIO SOBRE CRONOESTRATIGRAFIA DA BACIA DO PARANÁ, 1, Rio Claro. 1993. Resumos... Rio Claro: Universidade Estadual Paulista, p. 93.

CARBONELL, B J.L; SAUCK, W., ATEKWANA, E. (2002) Aplicaciones geofísicas en el descubrimiento de plumas de contaminación en acuíferos superficiales. Disponível em: <http://www.igme.es/internet/web_aguas/ igme/publica/con_recu_acuiferos/002.pdf >. Acesso em 15/fev/2005.

CESARINI, D.C.P.; DIAS, C.L.; BARBOUR, E.D.; TOFFOLI, F.F. (2004) Gestão da qualidade e risco de contaminação do recurso hídrico subterrâneo. In: 
CONGRESSO BRASILEIRO DE ÁGUAS SUBTERRÂNEAS, 13, 2004, Cuiabá. Anais... Cuiabá: Associação Brasileira de Águas Subterrânea.

CAVALCANTE, A.T.; SANTOS, R.J.Q. (1996) Estudos hidrogeológicos para a préseleção de áreas destinadas à implantação de um lixão na região de Japaratinga e Maragogi - Alagoas - Brasil. In: CONGRESSO BRASILEIRO DE ÁGUAS SUBTERRÂNEAS, 9., 1996, Salvador Anais... Salvador: Associação Brasileira de Águas Subterrânea.

CAVALCANTI, S.S.; SATO, H.K.; LIMA, O.A.L. (2002) Geofísica elétrica na caracterização da hidrologia subterrânea na região do aterro metropolitano centro, Salvador, Bahia. Brazilian Journal of Geophysics, v. 19, n. 2, p 155-67.

CCPERH - COMITÊ COORDENADOR DO PERH, (1999). Relatório de situação dos recursos hídricos do Estado de São Paulo, 128 p. São Paulo.

CETESB- Companhia de Tecnologia de Saneamento Ambiental (2004) Relatório de qualidade das águas subterrâneas no Estado de São Paulo 2001 2003. Série Relatórios. São Paulo.

CETESB - Companhia de Tecnologia de Saneamento Ambiental (2001) Manual de gerenciamento de áreas contaminadas. 389 p. São Paulo.

CETESB - Companhia de Tecnologia de Saneamento Ambiental (1997) Relatório de Qualidade das Águas Subterrâneas no Estado de São Paulo. Série Relatórios. 106 p. São Paulo.

CONTIN NETO, D.; MATSUZAKI, S.S.; GADOTTI, R.F.; FREITAS, A.L.S.; BARBOSA, D.O. (1997) Avaliação da poluição e da contaminação das águas superficiais e subterrâneas em região de aterro controlado. In: SIMPÓSIO INTERNAZIONALE DI INGEGNERIA SANITÁRIA AMBIENTALE, 1997. Ravello. Anais... Ravello: ABES/ADIS/AIDIS. p. 556-563.

COTTAS, L.R. (1991) Definição de áreas adequadas para instalação de aterros industriais e sanitários em Rio Claro - SP. In: SIMPÓSIO SOBRE BARRAGENS 
DE REJEITOS E DISPOSIÇÃO DE RESÍDUOS, 2., Rio de Janeiro. Anais... Rio de Janeiro: CBGC. p. 253-261.

CUSTÓDIO, E. (1994) Gestion y protection del agua subterranea. Curso de actualizacion professional. In: CONGRESSO LATINOAMERICANO DE HIDROLOGI A SUBTERRANEA, 2., Anais... Santiago.

DAVINO, A.; SINELLI, O.; SOUZA, A.; CORREIA, C.T. (1982) Diabásios na região nordeste da Bacia do Paraná. In: CONGRESSO BRASILEIRO DE GEOLOGIA, 32.,1982, Salvador. Anais... Salvador: Sociedade Brasileira de Geologia. p. 1736-1744.

DOMINGUES, A.F.; OLIVEIRA, F. R. (2004) Gestão integrada de aqüíferos. In: CONGRESSO BRASILEIRO DE ÁGUAS SUBTERRÂNEAS, 13, 2004, Cuiabá. Anais... Cuiabá: Associação Brasileira de Águas Subterrânea.

ELBACHÁ, A.T. (1989) Estudo da Influência de Alguns Parâmetros no Transporte de Massa em Solos Argilosos. 178p. Dissertação (Mestrado). PUC-RIO.

ELIS, V.R. (2000) Modelagem 2D de ensaios de caminhamento elétrico dipolo-dipolo realizados em áreas de disposição de resíduos. Revista Brasileira de Geociências, v. 19, n. 1, p. 119-34.

ELIS, V.R. (1998) Avaliação da aplicação de métodos elétricos de prospecção geofísica no estudo de áreas utilizadas para disposição de resíduos. 264 p. Tese (Doutorado em Geociências e Meio Ambiente) - Instituto de Geociências e Ciências Exatas, UNESP.

ELIS, V.R. (1993) A aplicação de geofísica para análise do meio físico: importância para elaboração de mapeamento geotécnico. 120p. Dissertação (Mestrado). Instituto de Geociências e Ciências Exatas - UNESP.

ELIS, V.R.; ZUQUETTE, L.V. (2002) Caracterização geofísica de áreas utilizadas para disposição de resíduos sólidos urbanos. Revista Brasileira de Geociências, v. 32 , n. 1, p. 103-112. 
ELIS,V.R.; ZUQUETTE, L.V. (1996) Caminhamento elétrico dipolo-dipolo - Uma técnica eficiente na investigação de depósitos de resíduos. In: CONGRESSO BRASILEIRO DE GEOLOGIA DE ENGENHARIA, 8, 1996, Rio de Janeiro. Anais... Rio de Janeiro.

ELIS, V.R.; ZUQUETTE, L.V. (1995) Aplicação de geofísica na obtenção de informações para mapeamento geotécnico. Revista do Instituto Geológico, São Paulo, volume especial, p.125-130, 1995.

ELLERT, N.; GREENHOUSE, J.; WILLIAMS, M.M.; MENDES, J.M.B.; HASSUDA, S. (1986). A geofísica aplicada na identificação da poluição do sub-solo por depósitos de rejeitos urbanos e industriais. In: CONGRESSO BRASILEIRO DE ÁGUAS SUBTERRÂNEAS, 4., 1986, Brasília. Anais... Brasília: Associação Brasileira de Águas Subterrâneas. p. 528-531.

EMBRAPA - EMPRESA BRASILEIRA DE PESQUISA AGROPECUÁRIA (2004). Disponível em <http://www.cnpma. EMBRAPA.br/projetos/index.php3?sec=guara>. Acesso em 11/nov/2004.

FERNANDES, C.E.M. (1984) Fundamentos de Prospecção Geofísica, Rio de J aneiro, Editora Interciência.

FERNANDES, L.A. (2004) Mapa litoestratigráfico da parte oriental da Bacia Bauru (PR, SP, MG), escala 1:1.000.000. Boletim Paranaense de Geociências, v. 55, p. 53-66.

FERRANTE, J.E.T. (1990) Mapeamento Geotécnico Regional da Bacia do Alto Jacaré-Guaçu - SP, com base nas aplicações técnicas de sensoriamento remoto e sistema geográfico de informação. 183p. Dissertação (Mestrado) - Escola de Engenharia de São Carlos, Universidade de São Paulo.

FETTER, C. W. (1993). Contaminant hydrogeology. First Edition. Book Press, Inc. New York. 458p.

FOSTER, S.; HIRATA, R.C.; ROCHA, G.A. (1988) Riscos de poluição de águas subterrâneas: Uma proposta metodológica de avaliação regional. In: 
CONGRESSO BRASILEIRO DE ÁGUAS SUBTERRÂNEAS, 5., 1988, São Paulo. Anais... São Paulo: Associação Brasileira de Águas Subterrâneas. p. 175246.

FOSTER, S. (1998) Jornadas sobre la contaminación de las aguas subterraneas: un problema pendiente. In: CONFERENCIA INAUGURAL: POLÍTICAS DE PROTECCIÓN DE LAS AGUAS SUBTERRÁNEAS EN EUROPA, 1998, Valencia. Atas... Valencia: AlH-GE. p. 25-38.

FOSTER, S.; HIRATA, R. (1993). Determinação do risco de contaminação das águas subterrâneas: um método baseado em dados existentes. Instituto Geológico (Boletim 10), São Paulo.

FREEZE, R.A.; CHERRY, J. A. (1979) Groundwater. New .Jersey: Prentice-Hall, Inc, 1979. $604 p$.

FREITAS, A.L.S. (1996) Caracterização do aqüífero Botucatu na região do Lixão de São Carlos - SP. 113p. Dissertação (Mestrado) - Escola de Engenharia de São Carlos, Universidade de São Paulo.

FUSCONI, R.; GODINHO, M.J.L. (1999) bactéria and protozoa populations in groundwater in a landfill área in São Carlos, SP. Revista de Microbiologia, v. 30, p.196-202.

GADOTTI, R.F. (1997) Avaliação da contaminação das águas superficiais e subterrâneas adjacentes ao lixão da cidade de São Carlos. 151p. Dissertação (Mestrado) - Departamento de Hidráulica e Saneamento, Escola de Engenharia de São Carlos, Universidade de São Paulo.

GALLAS, J.D.F. (2000) Principais métodos geoelétricos e suas aplicações em prospecção mineral, hidrogeologia, geologia de engenharia e geologia ambiental . 172p. Tese (Doutorado) - Instituto de Geociências e Ciências Exatas, Universidade Estadual Paulista.

GALLAS, J.D.F.; MAGALUTTI FILHO, W.; PRADO, R.L.; TAIOLI, F. (1993) Lixão do Alvarenga - Mapeamento da pluma de contaminação pelos métodos geoelétricos. In: INTERNATIONAL CONGRESS OF THE BRAZILIAN 
GEOPHYSICAL SOCIETY, 8., 1993, Rio de Janeiro. Anais... Rio de Janeiro: Sociedade Brasileira de Geofísica. p. 82-88.

GONÇALVES, A.R.L. (1986) Geologia ambiental da área de São Carlos. 138p. Tese (Doutorado) - Instituto de Geociências, Universidade de São Paulo.

GONÇALVES, A.R.L.; BOSSOLAN, N.R.S.; ORLANDO, M.J.G. (1992) Determinação da direção do fluxo defreativo no aterro sanitário de São Carlos. In: CONGRESSO BRASILEIRO DE ÁGUAS SUBTERRÂNEAS, 7., 1992, Belo Horizonte. Anais... Belo Horizonte: Associação Brasileira de Águas Subterrâneas.

GANDOLFO, O.C.B. (1999) Aplicação da sísmica de reflexão de alta resolução e do radar de penetração no solo (GPR): Um estudo comparativo. 110p. Dissertação (Mestrado) - Instituto de Geociências e Ciências Exatas, Unesp.

GOMES, L. P. (1991). Caracterização Física dos resíduos sólidos urbanos da cidade de São Carlos - SP. Estudos Tecnológicos. Engenharia 9 e 10. v.14, p.91-105.

HASSUDA, S.; REBOUÇAS, A.C.; CUNHA, R.C.A.; MARKER, A. (1998) Critérios para classificacao de áreas contaminadas por resíduos sólidos - Estudo de caso na região metropolitana de São paulo. In: CONGRESSO LATINO AMERICANO DE HIDROLOGIA SUBTERRÂNEA, 4., 1998, Montevideo. Anais... Montevideo: ALHSUD. p.927-943.

HAITJEMA, H.M. (1991) Ground water hydraulics considerations regarding landfills. Water Resources Bulletin - American Water Resources Association, V 27, n 5, p 791-96.

HIRATA, R. (2004) Hidrologia aplicada ao controle da poluição: conceitos básicos. In: CURSO DE EXTENSÃO: Contaminação de solo e água subterrânea: caracterização, monitoramento e Remediação, 2004, Curitiba. Apostila... Curitiba: Pontifícia Universidade Católica do Paraná, 2004. 164p.

HIRATA, R. (2000) Recursos Hídricos. In: Wilson Teixeira; Fábio Taioli; Maria Cristina Motta de Toledo; Thomas Rich Fairchild (Org). Decifrando a Terra. Cap. 20: p. 421-444. São Paulo. 
IBGE - INSTITUTO BRASILEIRO DE GEOGRAFIA e ESTATíSTICA (2002) Pesquisa Nacional de Saneamento Básico. Disponível em <http://www.ibge.com.br>. Acesso em 03/mar/2006.

IBGE - INSTITUTO BRASILEIRO DE GEOGRAFIA e eStATÍStICA (2000) Pesquisa Nacional de Saneamento Básico. Disponível em <http://www.ibge.com.br>. Acesso em 03/mar/2006.

IBGE - INSTITUTO BRASILEIRO DE GEOGRAFIA E ESTATÍSTICA (1991) Classificação da vegetação brasileira, adaptada a um sistema universal. Rio de Janeiro. $122 \mathrm{p}$.

IPT - INSTITUTO DE PESQUISA DO ESTADO DE SÃO PAULO (1995) Lixo municipal: Manual de gerenciamento integrado. São Paulo. Publicação 2163. 278p.

IPT - INSTITUTO DE PESQUISAS TECNOLÓGICAS DO ESTADO DE SÃO PAULO (1981) Mapa Geomorfológico do estado de São Paulo. Escala 1:500.000. V. 1 (texto). São Paulo.

KYRILLOS, D.S.; CABRAL, J.J.S.P. (1996) modelagem de propagação de poluentes em água subterrânea utilizando o método de elementos de contorno. In: CONGRESSO BRASILEIRO DE ÁGUAS SUBTERRÂNEAS, 9., 1996, Salvador. Anais... Salvador: Associação Brasileira de Águas Subterrâneas.

LEITE, W.C. A. (1997). Estudo da gestão de resíduos sólidos: uma proposta de modelo tomando a unidade de Gerenciamento de Recursos Hídricos (UGRHI 5) como referência. 270p. Tese (Doutorado) - Escola de Engenharia de São Carlos, Universidade de São Paulo.

LEPSCH, I. F. (1994) Solos do Estado de São Paulo. In: LOMBARDI NETO, F.; DRUGOWICH, M. I. (coord.). Manual Técnico de Manejo e Conservação de Solo e Água. Campinas, v. 2, n. 39, p 70-120, : CATI, 1994. p.70-120, 1994.

LIMA, O.A.L.; PORSANI, M.J., (1994). Monitoramento geo-elétrico da contaminação aqüífera no pólo petroquímico de Camaçari, Bahia, Revista Brasileira de Geofísica, v. 12, n.2, p.147-161. 
LOKE, M.H.; BARKER, R.D. (1996). Rapid least-squares inversion of apparent resistivity pseudosections by quasi-Newton method. Geophysical Prospecting , v. 44, p. 131-152.

LOPES, A.A. (2003). Estudo da gestão e do gerenciamento integrado dos resíduos sólidos urbanos no município de São Carlos (SP). Dissertação (Mestrado) - Escola de Engenharia de São Carlos, Universidade de São Paulo.

MALAGUTTI FILHO, W; JOSÉ, C.; BRAGA, A.C.O.; ELIS, V.R.; TANDEL, R.Y.; PORSANI, J.L. (1997) Aplicação integrada de técnicas geofísicas no aterro sanitário de Rio Claro - SP, resultados preliminares. In: Congresso Internacional da Sociedade Brasileira de Geofísica, 5., 1997 Anais... p. 422-424.

MATHEUS, C. E. ; MORAES, A. J. ; TUNDISI, J. G. (1992) Áreas alagadas da bacia Hidrográfica do ribeirão do Feijão como sistema de proteção da qualidade das águas de abastecimento de São Carlos. In: CONGRESSO LATINO-AMERICANO DE ECOLOGIA, 2.; CONGRESSO DE ECOLOGIA DO BRASIL, 1., 1992, Caxambu. Resumos... Rio Claro: SEB.

MATSUZAKI, S.S. (1998) Aplicação de modelo computacional de escoamento de água subterrânea no lixão de São Carlos. 113p. Dissertação (Mestrado) Escola de Engenharia de São Carlos, Universidade de São Paulo.

MELO, J.G.; REBOUÇAS, A.C.; QUEIROZ, M.A. (1996) Avaliação dos riscos potenciais de contaminação das águas subterrâneas na zona sul de Natal, RN. In: CONGRESSO BRASILEIRO DE ÁGUAS SUBTERRÂNEAS, 9., 1996, Salvador. Anais... Salvador: Associação Brasileira de Águas Subterrânea.

MENDES, J.M.B. (1987) Técnicas geofísicas aplicadas no mapeamento e monitoramento de poluição e contaminação de águas subterrâneas. 196p. Tese (Doutorado) - Instituto de Geociências, Universidade de São Paulo.

MENDES, L.R.L.; VERMA, O.P. (2002) Prospecção de água subterrânea na região de Belém (PA) através de perfilagem geofísica de poço e eletrorressistividade. Revista Brasileira de Geociências, v. 32, n. 1, p. 87-94. 
MENEZES, D.B. (1995) Diagnóstico dos impactos do depósito de resíduos sólidos de São Carlos - SP, no meio físico. 103p. Dissertação (Mestrado) - Escola de Engenharia de São Carlos, Universidade de São Paulo.

MENEZES, D.B.; CONTIN NETO, D.; SCHALCH, S.; (1995) Diagnóstico de impactos no meio físico causados por depósitos de resíduos sólidos. In: CONGRESSO BRASILEIRO DE ENGENHARIA SANITÁRIA, 18., 1995, Salvador. Anais... Salvador: Associação Brasileira de Engenharia Sanitária e Ambiental.

MILANI, E.J .; RAMOS, V.A. (1998) Orogenias Paleozóicas no Domínio Sul-Ocidental do Gondwana e os Ciclos de Subsidência da Bacia do Paraná. Revista Brasileira de Geociências, v. 28 , n. 4, p. 473-484.

MILANI, E.J. 1997. Evolução Tectono-Estratigráfica da Bacia do Paraná e seu relacionamento com a Geodinâmica Fanerozóica do Gondwana SulOcidental. Tese (Doutorado) - Universidade Federal do Rio Grande do Sul.

MILANI, E. J.; FRANÇA, A. B.; SCHNEIDER, R. L. (1994) Bacia do Paraná. Boletim Geociências Petrobrás. São Paulo, v. 8, n. 1, p. 69-82.

MIRANDA, E. E. - Coord. (2005) Sistema de gestão territorial para a ABAG/ RP. EMBRAPA Monitoramento por Satélite, Campinas. Disponível em: <http://www.abagrp.cnpm. EMBRAPA.br>. Acesso em 02/fev/2006.

MIRANDA, E. E.; COUTINHO, A. C. - Coord. (2001) Brasil Visto do Espaço. EMBRAPA Monitoramento por Satélite, Campinas. Disponível em: <http://www.cdbrasil.cnpm.EMBRAPA.br>. Acesso em 22/mar/2005.

MIRECKI, J.E.; PARKS, W.S. (1994) Leacheate geochemistry at a municipal landfill, Menfhis, Tenesse. Ground Water, v.32, n. 3, p. 390-398.

MITCHELL, J.K. (1991) Conduction phenomena: from theory to geotechnical pratice. Géotechnique, v. 41, n. 3, p. 299-340, 1991.

MMA - MINISTÉRIO DO MEIO AMBIENTE (2001) Programa de Águas Subterrâneas. Brasília, 2001. 21 p. 
MOTA, R.; FIALHO RODRIGUES, L. (1998). Prospecção geofísica no local do Açude de Pedrogão. Lisboa: LNEC, (Relatório 191/98 - NP, LNEC).

MURO, M.D. (2000) Carta de zoneamento para seleção de áreas frente à instalação de aterros sanitários no município se São Carlos-SP. 172p. Dissertação (Mestrado) - Escola de Engenharia de São Carlos, Universidade de São Paulo.

NISHIYAMA, L.; ZUQUETTE, L.V. (1991) Carta para deposição de rejeitos da região da quadrícula de São Carlos - SP: Estudo preliminar. In: SIMPÓSIO DE GEOLOGIA DO SUDESTE, 2., 1991, São Paulo. Atas... São Paulo: Sociedade Brasileira de Geofísica. p. 315-322.

NOBRE, M.M.M. (1987) Estudo experimental do transporte de poluentes em solos argilosos compactados. 214p. Dissertação (Mestrado). PUC-RIO.

OLIVEIRA, J.B. (1999) Solos do Estado de São Paulo: descrição das classes registradas no mapa pedológico. Boletim Científico do IAC - Instituto Agronômico, Campinas, n. 45. 112p, 1999.

PENNER, G.C. (2003) Alternativas de controle hidráulico aplicadas à pluma de poluentes do antigo lixão de São Carlos - SP. Resumos São Carlos: CRHEA/EESC-USP.

PFEIFFER, S.C. (1993) Avaliação da viabilidade técnico-econômica de aproveitamento de águas subterrâneas na área urbana de São Carlos - SP. Dissertação (Mestrado) - Escola de Engenharia de São Carlos, Universidade de São Paulo.

PREFEITURA MUNICIPAL DE SÃO CARLOS (2005) Processo de Elaboração do Plano Diretor do Município de São Carlos. Secretaria Municipal de Habitação e Desenvolvimento Urbano-SMHDU. São Carlos.

REBouÇAS, A. C.; Braga, B.; Tundisi, J. G. (2002) Águas Doces no Brasil: Capital ecológico, uso e conservação. 2ed. São Paulo: Escrituras, 2002. 704p. 
RIOS, L. (1993) Estudo limnológico e fatores ecológicos em córregos e ribeirões da Bacia hidrográfica do Ribeirão do Feijão (Estado de São Paulo). 146p. Dissertação (Mestrado) - Escola de Engenharia de São Carlos, Universidade de São Paulo.

ROCHA, G. A. Um copo d’água. São Leopoldo: Editora Unisinos, 2002. 107p.

ROSS, J.L.S. \& MOROZ, I.C. (1997) Mapa Geomorfológico do Estado de São Paulo. Escala 1:500.000. Departamento de Geografia FFLCH - USP - IPT FAPESP. São Paulo.

SAARELA, J., (1993) Types and costs of covers of closed landfill sites. In: International Landfill Symposium, 4., Sardinia. Anais... Sardinia

SANCHEZ, L.E. (1998) A desativação de empreendimentos industriais: um estudo sobre o passivo ambiental. Tese (Livre-Docência) - Escola Politécnica, Universidade de São Paulo

SANTIAGO, R.C. (2002) Avaliação geofísica do sistema aqüífero da área costeira entre I piranga e rio Joanes. Trabalho de Graduação Universidade Federal da Bahia.

SANTOS, C.P.L. (2003) Analise geofísica das características hidráulicas da Falha de Salvador na Região de Arembepe - Ba. 93p. Dissertação (Mestrado) Pós-graduação em Geofísica, Instituto de Geociências da Universidade Federal da Bahia.

SANTOS, L.J .; KOIDE, S. (1998) Poluição dos recursos hídricos em áreas de aterro de lixo - Caso: Lixão do Jockey Club (DF). In: CONGRESSO LATINO AMERICANO DE HIDROLOGI A SUBTERRÂNEA, 4., 1998, Montevideo. Anais... Montevideo: ALHSUD. p.700-719.

SCHALCH, V. (1992) Análise comparativa do comportamento de dois aterros sanitários semelhantes e correlações dos parâmetros do processo de digestão anaeróbia. 220p. Tese (Doutorado) - Departamento de Hidráulica e Saneamento, Escola de Engenharia de São Carlos, Universidade de São Paulo. 
SCHALCH, V.; LEITE, W.C.A.; FERNANDES JÚNIOR, J.L.; CASTRO, M.C.A.A. (2002). Gestão e gerenciamento de resíduos sólidos. Apostila... São Carlos: Universidade de São Paulo, Escola de Engenharia de São Carlos, Departamento de Hidráulica e Saneamento, 93p.

SHACKELFORD, C.D. (1988) Diffusion as a Transport Process in Fine Grained Materials. Geotechnical News, v. 6, n. 2, p. 24-27, 1988.

SILVA, R.B.G. (1983) Estudo hidroquímico e isotópico das águas subterrâneas do aqüífero Botucatu no estado de São Paulo. Tese (Doutorado) Instituto de Geociências, Universidade de São Paulo.

SMA/SP - SECRETARIA DO MEIO AMBIENTE DO ESTADO DE SÃO PAULO (2004) Mapa de Vegetação Remanescente do estado de São Paulo. Programa Biota/Fapesp, Instituto Florestal. São Paulo Disponível em: <http://sinbiota.cria.org.br/atlas>. Acesso em: 03 fev 2006.

SOARES, P.C. (1973) O Mesozóico Gondwânico no Estado de São Paulo. 152p. Tese (Doutorado) - Faculdade de Filosofia, Ciências e Letras de Rio Claro.

SUGUIO, K. (1998) Dicionário de Geologia Sedimentar e Áreas Afins. Rio de Janeiro: Bertrand Brasil, 1998. 1217p.

TELFORD, W.M.; Geldart, L.P. e Sheri. R.E. (1990) Applied Geophysics, Cambridge University Press, 2ed. 770p.

TOLENTINO, M. (1967) Estudo crítico sobre o clima da região de São Carlos. 1967. 78 p. Concurso de Monografias Municipais - Prefeitura Municipal de São Carlos.

TRESSOLDI, M.; CONSONI, A.J. (1994) Disposição de resíduos. In: Antônio Manoel dos santos Oliveira e Sérgio Nertan Alves de Brito (Org). Geologia de Engenharia. Cap 21: p. 361-380. São Paulo.

VAGENTE, A.O.C.; GASPAR, R.L. (1994) A gestão integrada de águas subterrâneas e águas superficiais. In: SIMPÓSIO DE HIDRÁULICA E RECURSOS HÍDRICOS 
DOS PAÍSES DE LíngUA OFICIAL PORTUGUeSA, 6., Montevideo. Anais... Montevideo: ABRH/APRH. p.643-646.

VOGELSANG, D. (1995) Environmental Geophysics. A practical guide. SpringerVerlag, Berlim, 172p.

YOKOYAMA, L.M.L. (2003) O uso integrado de métodos geofísicos visando a caracterização geológica em um estudo de contaminação. Trabalho de Graduação - Instituto de Astronomia Geofísica e Ciências Atmosféricas Universidade de São Paulo.

YONG, R.N.; MOHAMED, A.M.O. (1992) Principles of contaminant transport in soils. Netherlands: Elsevier Science Publishers, 327p, 1992.

ZUQUETTE, L.V.; GANDOLFI, N. (2004) Cartografia geotécnica. São Paulo : Oficina de Texto. 190p, 2004.

ZUQUETTE, L.V.; GANDOLFI, N. (1991) Análise da relação entre disposição de rejeitos de baixa periculosidade e meio geológico receptor. In: SIMPÓSIO SOBRE BARRAGENS DE REJEITOS E DISPOSIÇÃO DE RESÍDUOS, 1991, Rio de Janeiro. Anais... Rio de Janeiro: REGEO. p.221-232. 


\section{Anexo I}

\section{Localização dos Poços}


Tabela com as coordenadas UTM e as cotas dos poços de monitoramento instalados por Freitas (1995), localizados por Álvares (2000) com GPS de precisão.

\begin{tabular}{|l|c|c|c|}
\hline POÇO & $\begin{array}{c}\text { COTA } \\
(\mathbf{m})\end{array}$ & $\begin{array}{c}\text { COORDENADA } \\
\text { NORTE }\end{array}$ & $\begin{array}{c}\text { COOREDENADA } \\
\text { LESTE }\end{array}$ \\
\hline $\mathbf{1 5}$ & 793 & 7.555 .212 & 209.988 \\
\hline $\mathbf{1 6}$ & 794 & 7.555 .127 & 210.113 \\
\hline $\mathbf{1 7}$ & 806 & 7.554 .943 & 210.204 \\
\hline $\mathbf{1 8}$ & 812 & 7.554 .826 & 210.242 \\
\hline $\mathbf{1 9}$ & 818 & 7.554 .730 & 210.274 \\
\hline $\mathbf{2 0}$ & 827 & 7.554 .654 & 210.297 \\
\hline $\mathbf{2 1}$ & 828 & 7.554 .621 & 210.250 \\
\hline $\mathbf{2 3}$ & 819 & 7.554 .708 & 210.190 \\
\hline $\mathbf{2 4}$ & 802 & 7.554 .905 & 210.086 \\
\hline $\mathbf{2 5}$ & 789 & 7.555 .100 & 209.905 \\
\hline $\mathbf{2 6}$ & 782 & 7.555 .167 & 209.815 \\
\hline $\mathbf{2 7}$ & 777 & 7.555 .209 & 209.784 \\
\hline $\mathbf{2 8}$ & 775 & 7.555 .232 & 209.798 \\
\hline $\mathbf{2 9}$ & 777 & 7.555 .264 & 209.814 \\
\hline $\mathbf{3 0}$ & 778 & 7.555 .210 & 209.850 \\
\hline $\mathbf{3 1}$ & 792 & 7.555 .159 & 209.973 \\
\hline $\mathbf{3 2}$ & 798 & 7.555 .026 & 210.099 \\
\hline $\mathbf{3 3}$ & 801 & 7.554 .932 & 210.117 \\
\hline & & & \\
\hline
\end{tabular}




\section{Anexo I I}

\section{Perfis Geofísicos}




\section{Linha 0-2005}

$\checkmark$ Dados de resistividade tratados no Surfer, linha 0 - 2005:

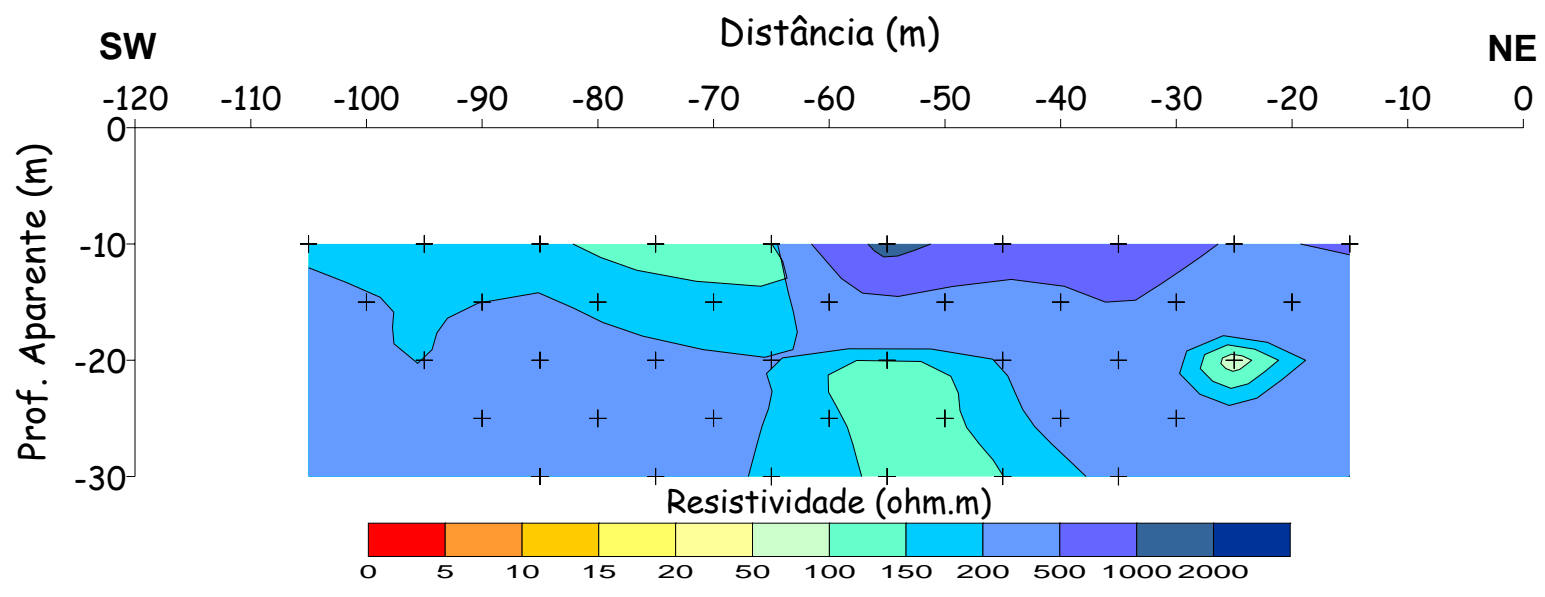

Dados de resistividade tratados no Res2dinv, linha 0 - 2005:

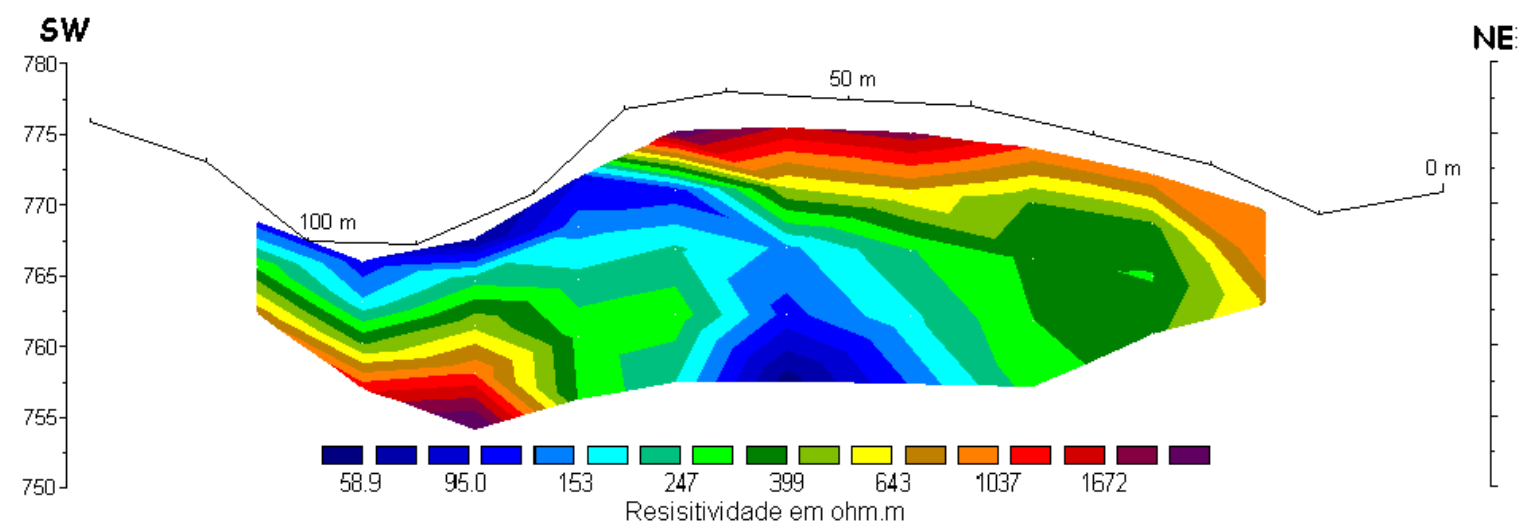

$\checkmark$ Dados de cargabilidade tratados no Surfer, linha 0 - 2005:

SW Distância (m)

NE

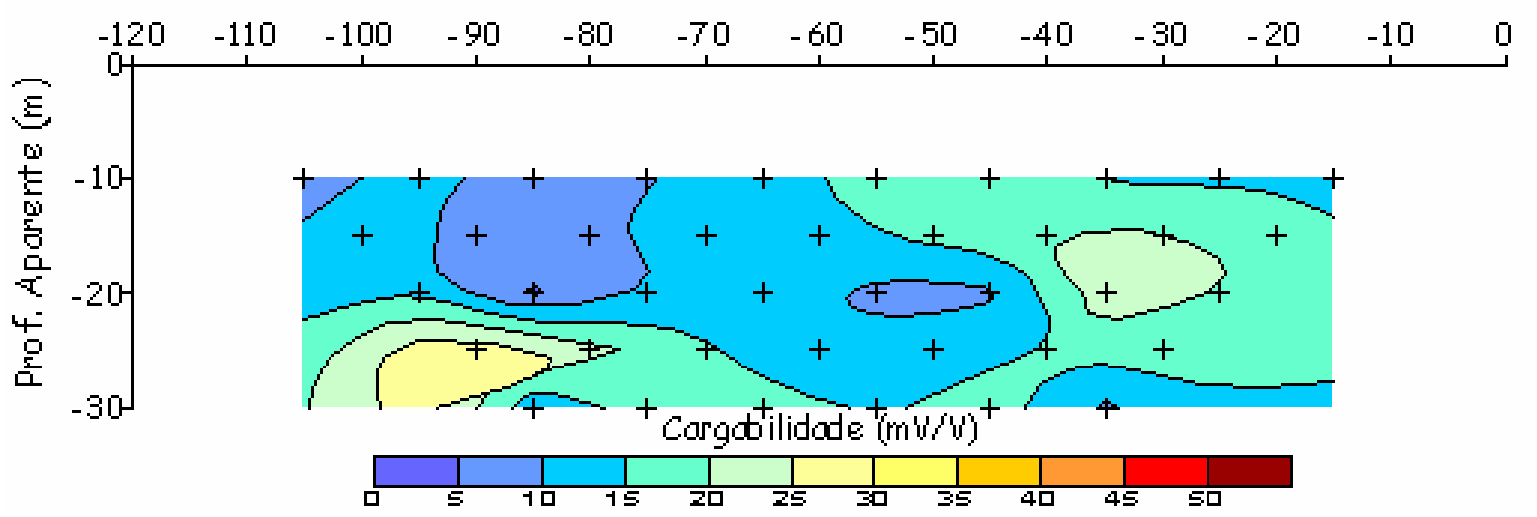


Dados de cargabilidade tratados no Res2dinv, linha 0 - 2005:

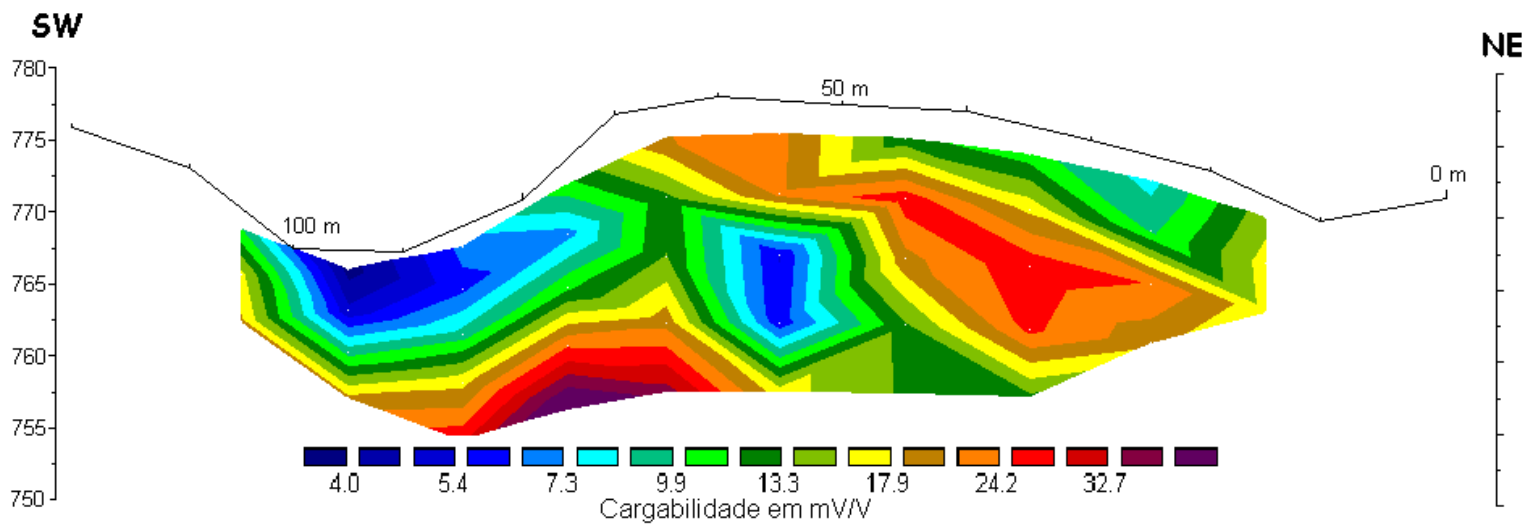




\section{Linha 1-2005}

$\checkmark$ Perfil linha 1 - 2005:

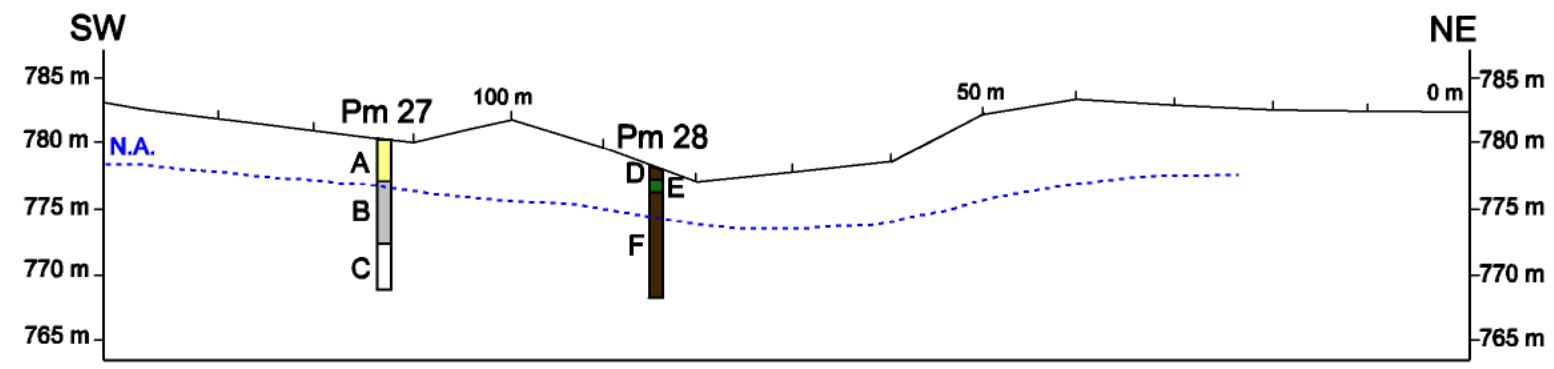

Pm 27

A- 0-3m: Areia fina siltosa

B- $\bigcirc$ 3-8m: Areia fina cinza

C-O 8-11,5m: Areia fina siltosa branca
Pm 28

D- 0-1m: Areia fina siltosa negra por influência de chorume

E- 1-2m: Areia fina siltosa negra com resíduos

F- 2-10m: Areia fina siltosa negra por influência de chorume

$\checkmark$ Dados de resistividade tratados no Surfer, linha 1 - 2005:

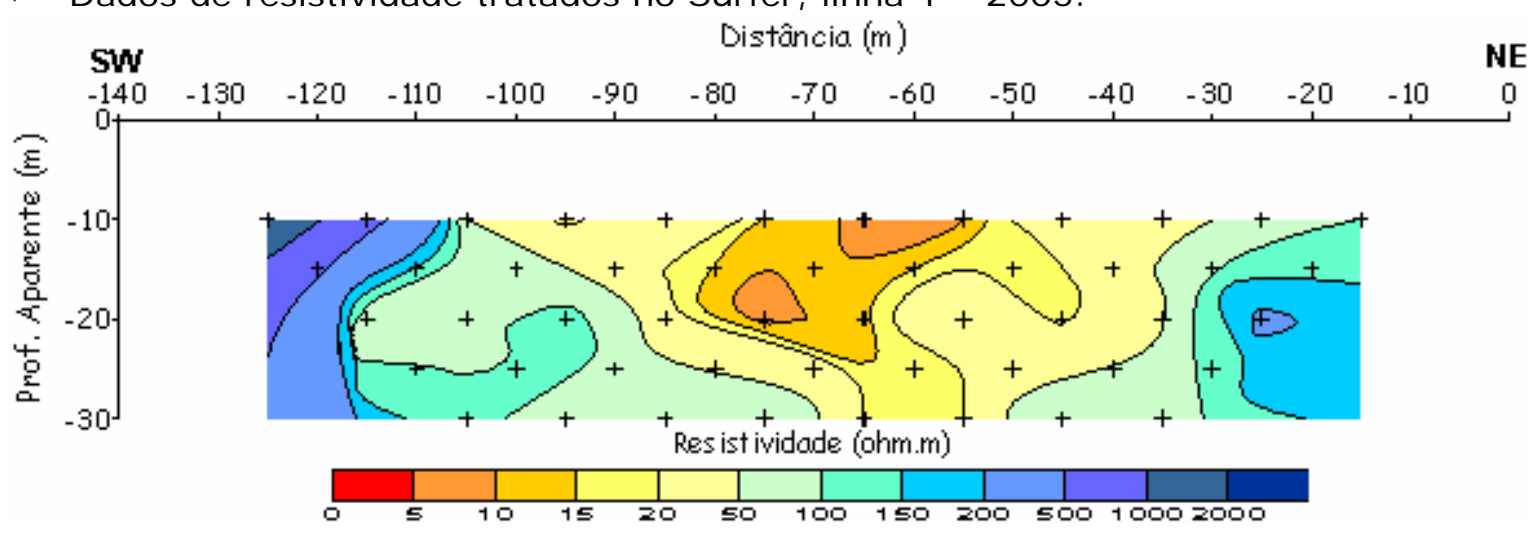

Dados de resistividade tratados no Res2dinv, linha 1 - 2005:

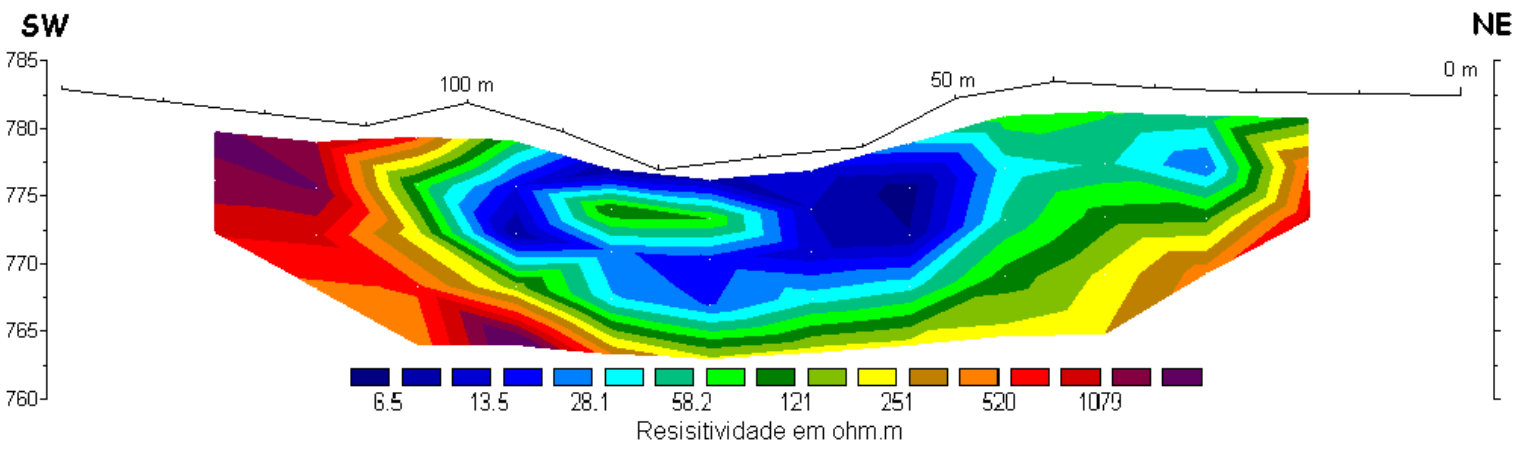

Dados de cargabilidade tratados no Surfer, linha 1 - 2005: 


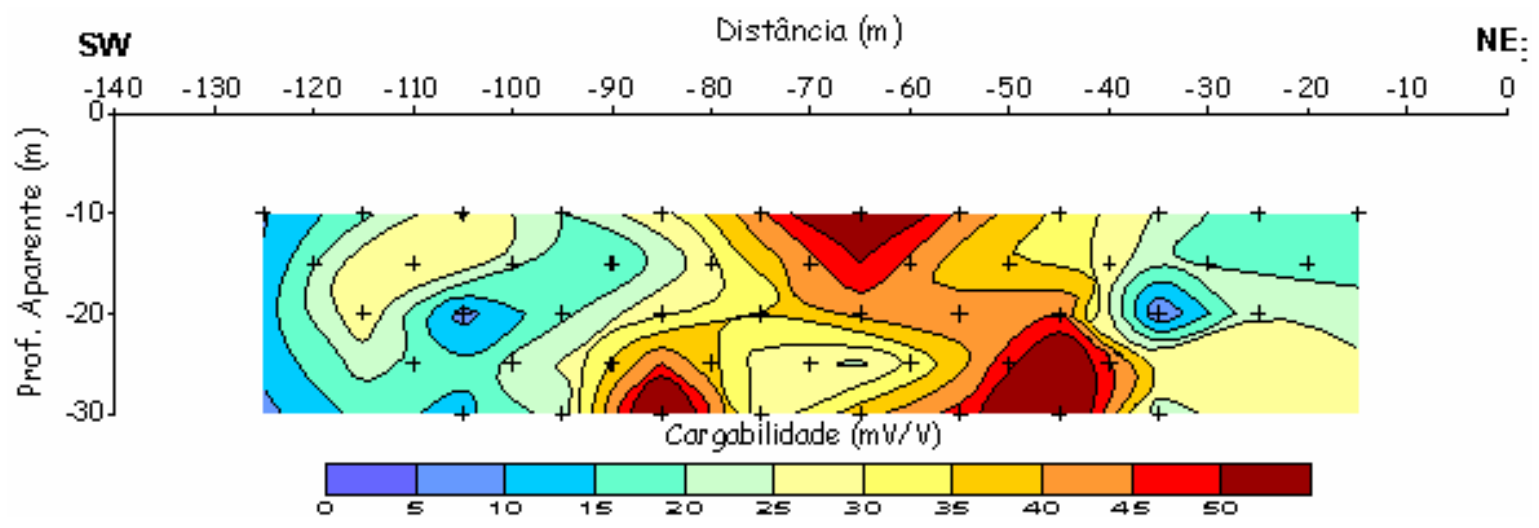

$\checkmark$ Dados de cargabilidade tratados no Res2dinv, linha 1 - 2005:

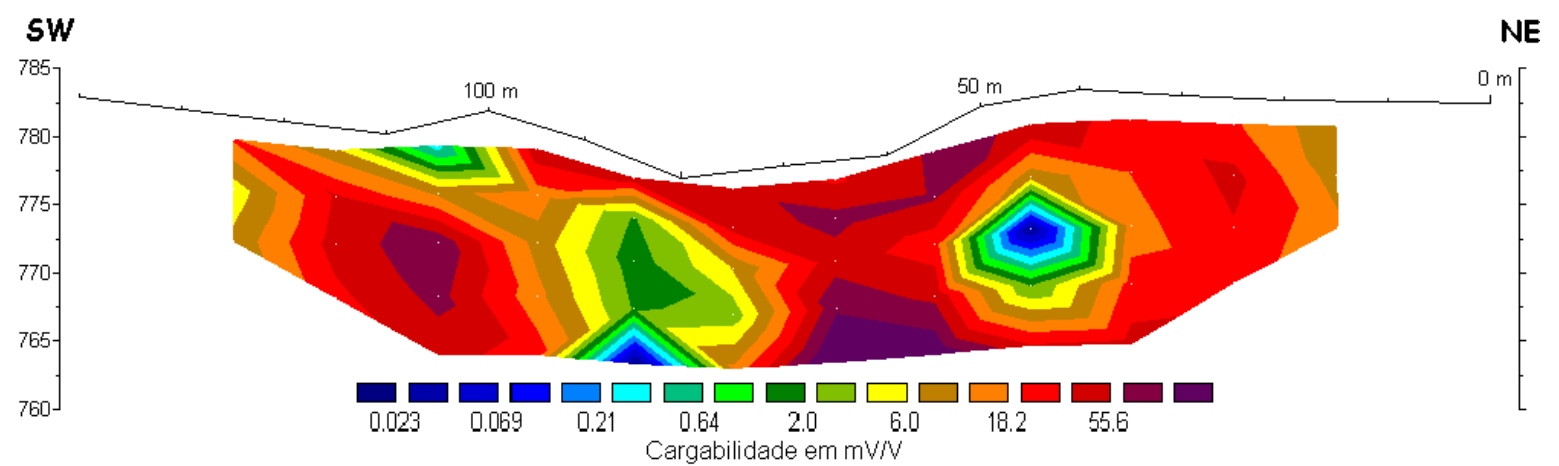




\section{Linha 2-2005 / 6-1995}

$\checkmark$ Perfil linha $2-2005$ / 6 - 1995:

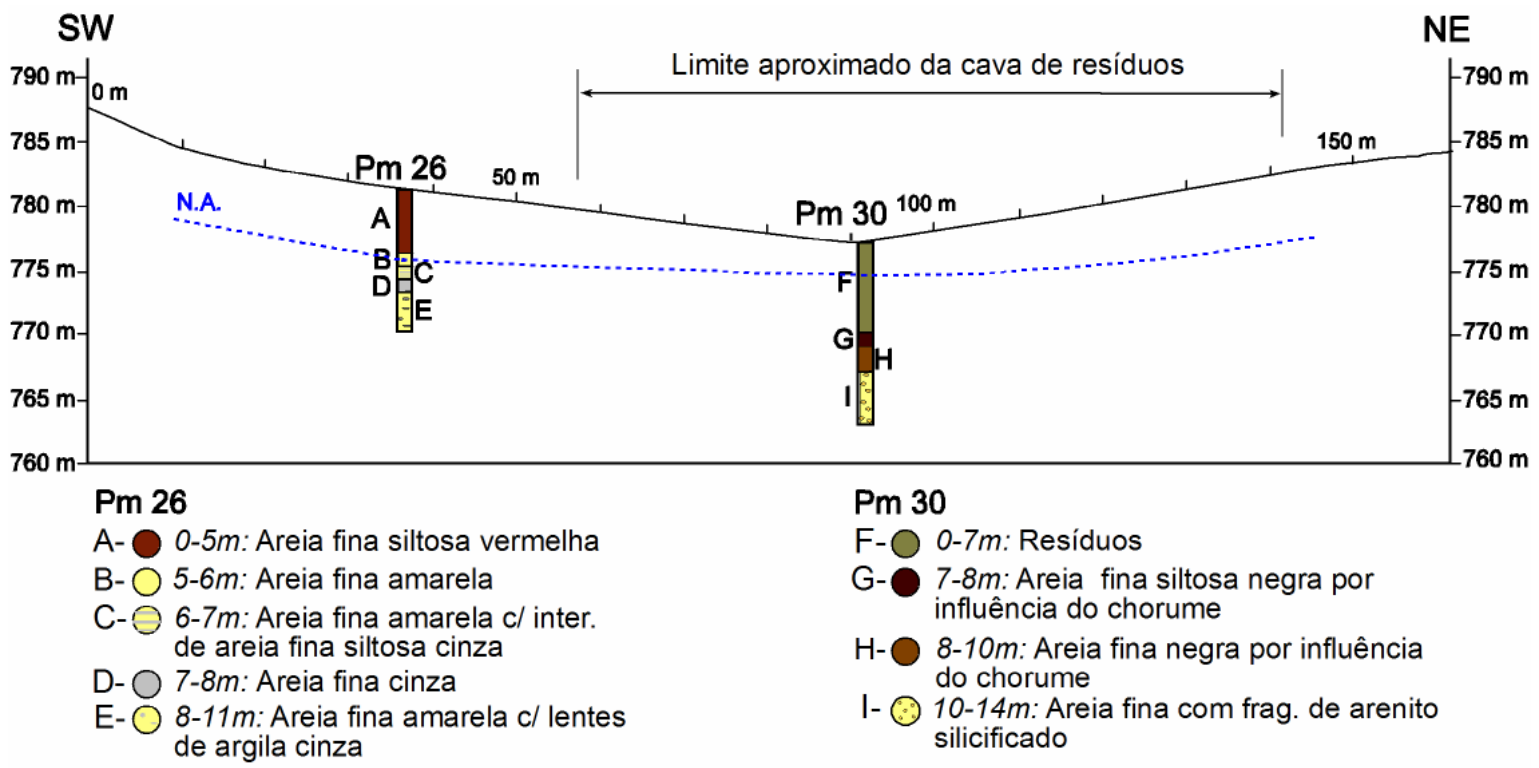

Dados de resistividade tratados no Surfer, linha 2 - 2005:

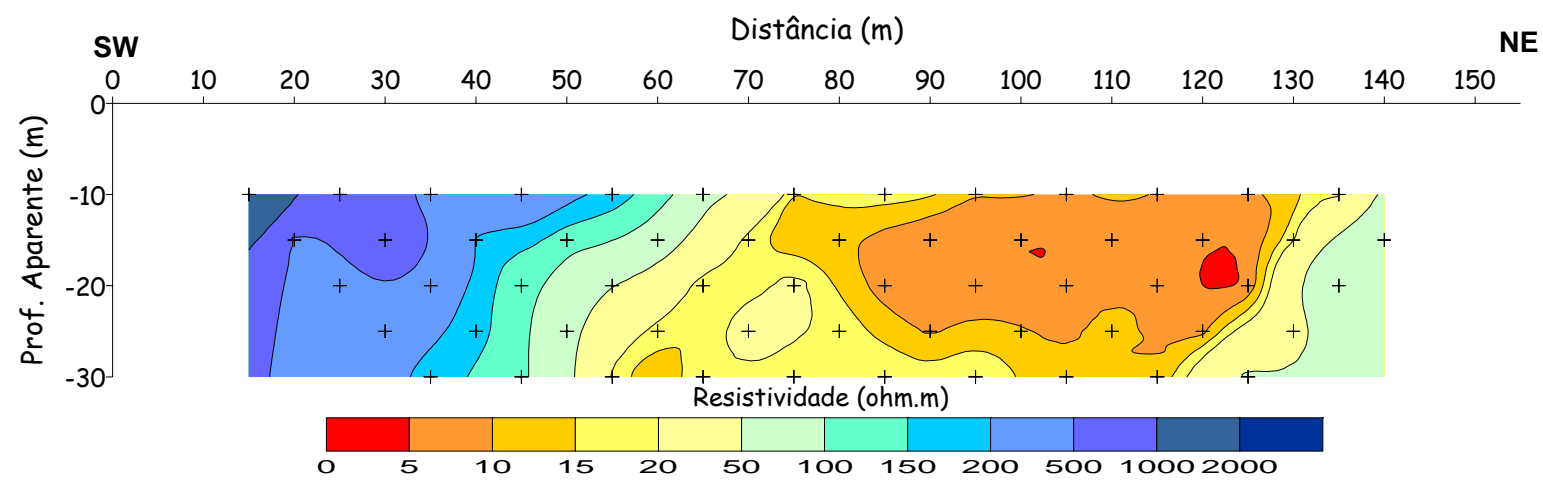

Dados de resistividade tratados no Res2dinv, linha 2 - 2005:

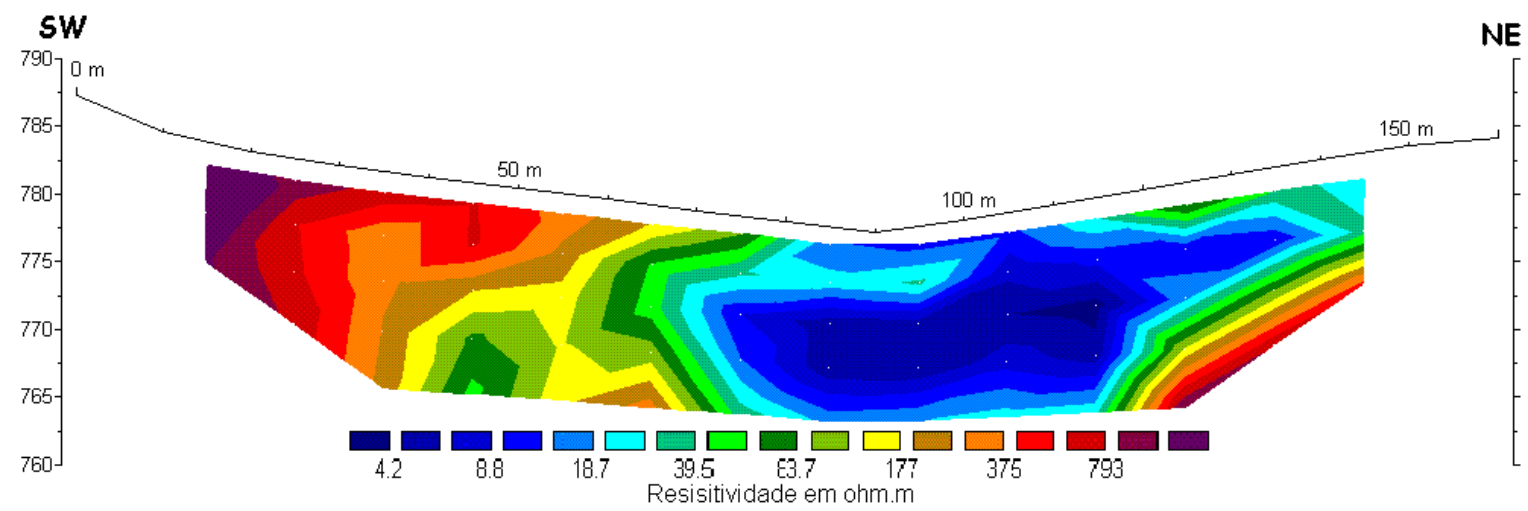


Dados de resistividade tratados no Surfer, linha 6 - 1995:

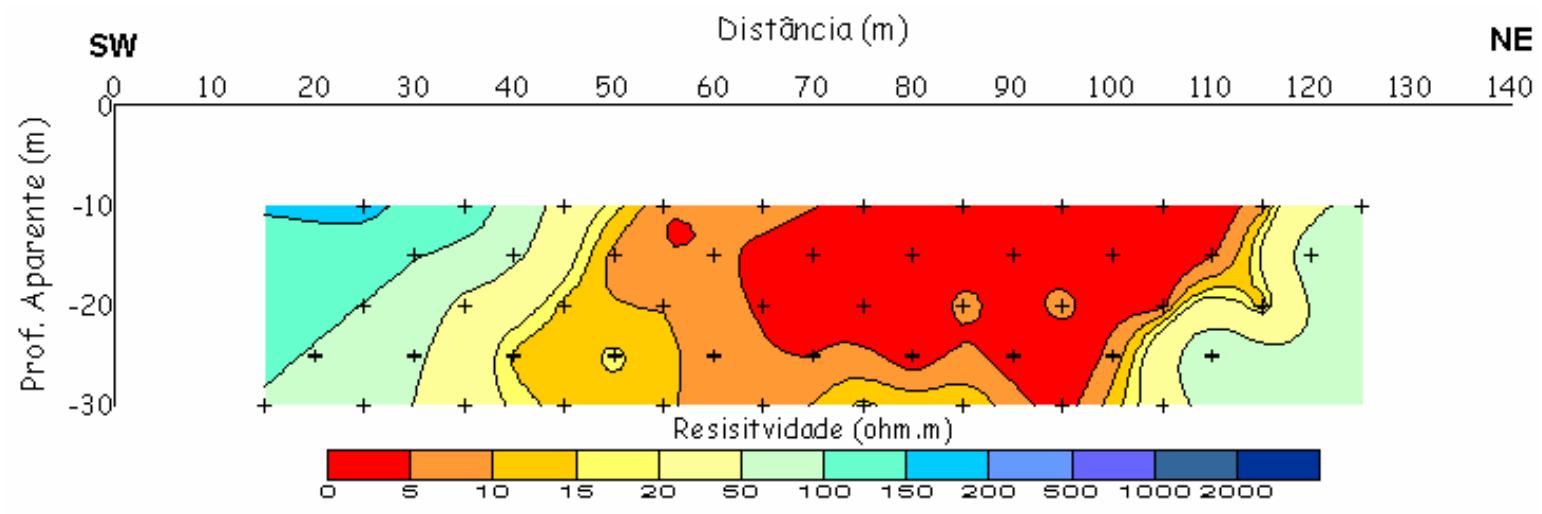

$\checkmark$ Dados de resistividade tratados no Res2dinv, linha 6 - 1995:

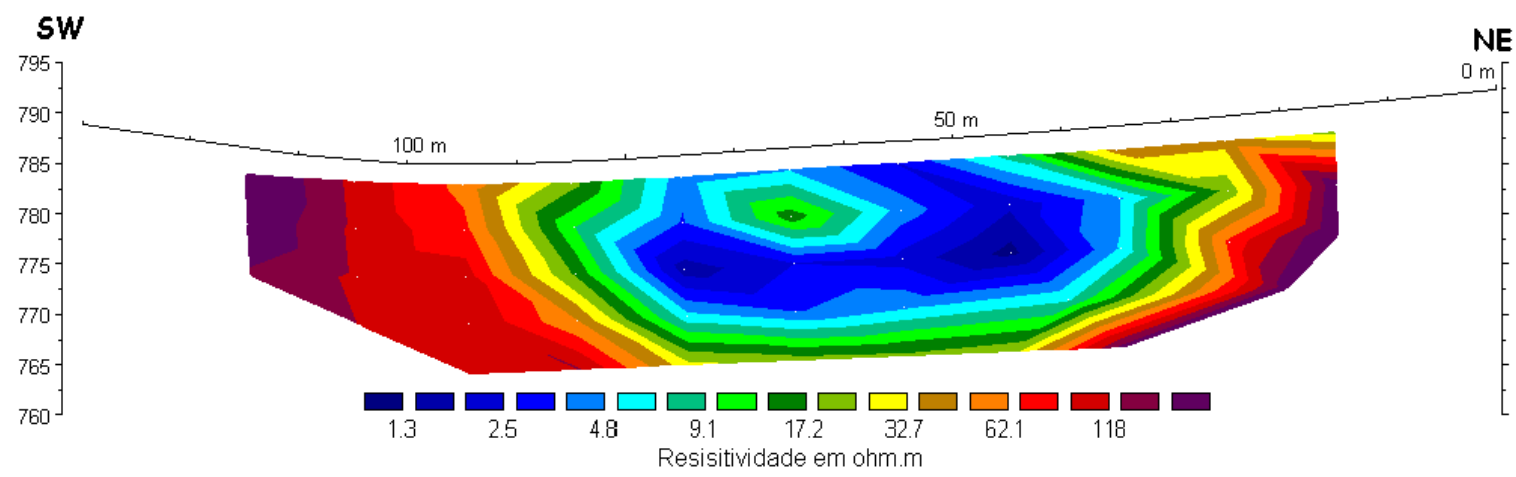

Dados de cargabilidade tratados no Surfer, linha 2 - 2005:

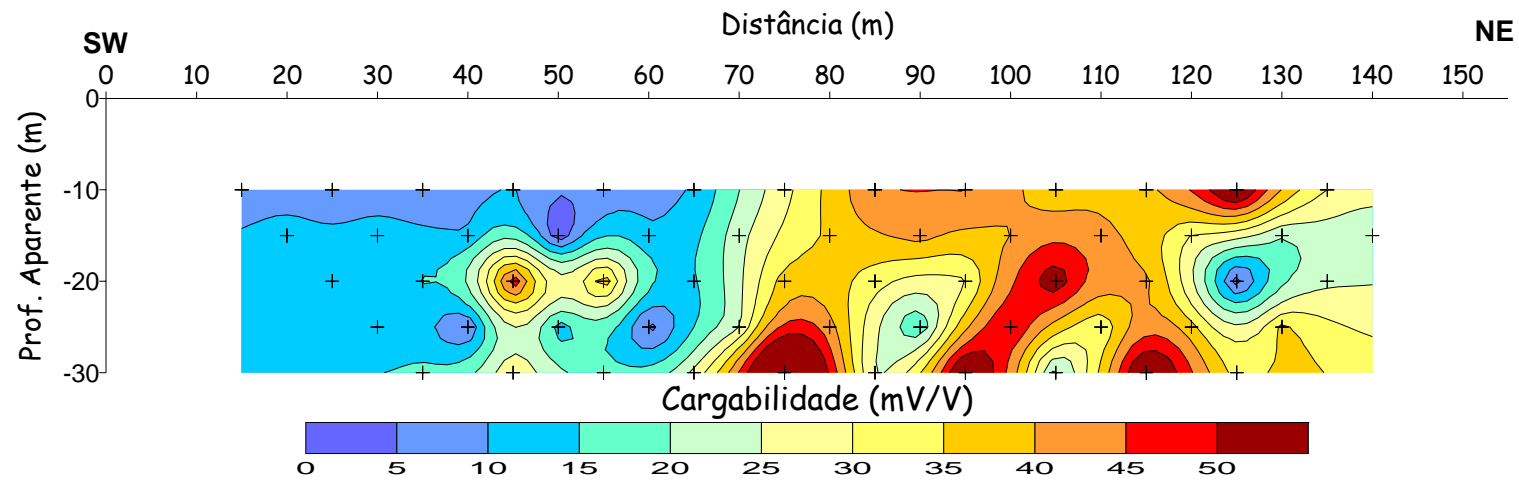


$\checkmark$ Dados de cargabilidade tratados no Res2dinv, linha 2 - 2005:

SW

NE

(1.1. 


\section{Linha 3-2005 / 5-1995}

$\checkmark$ Perfil linha $3-2005 / 5-1995$ :

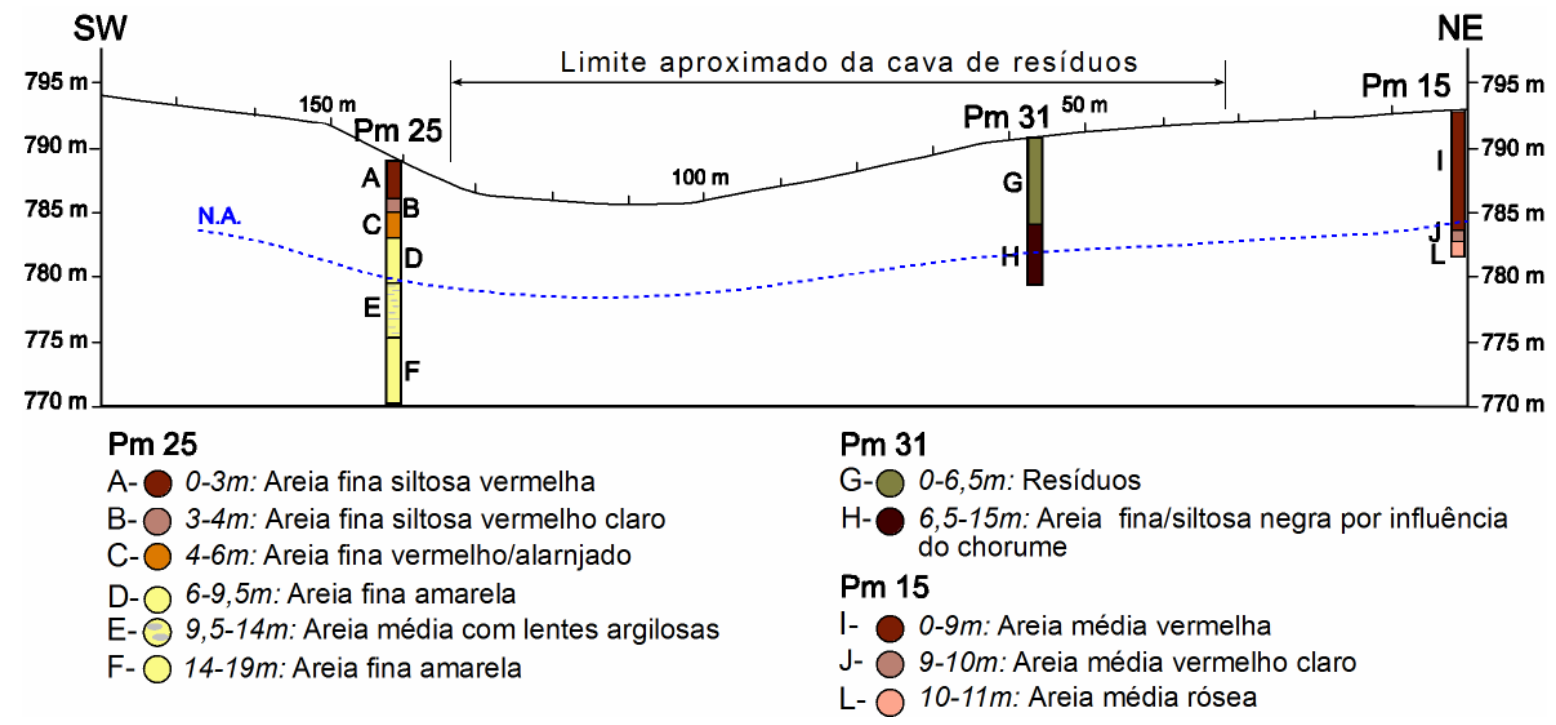

$\checkmark$ Dados de resistividade tratados no Surfer, linha 3 - 2005:

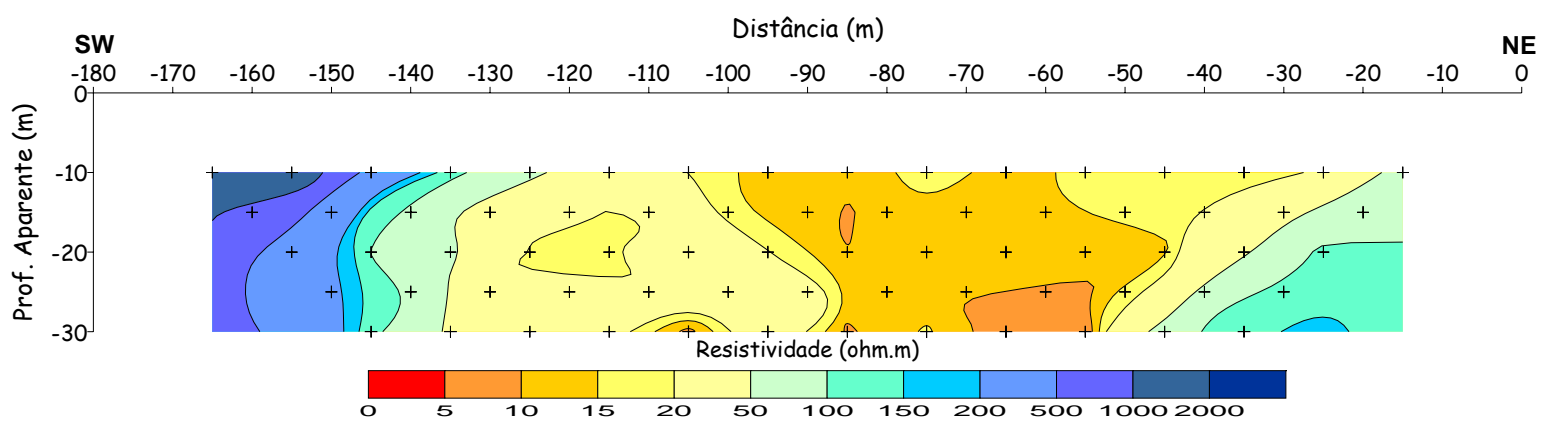

Dados de resistividade tratados no Res2dinv, linha 3 - 2005:

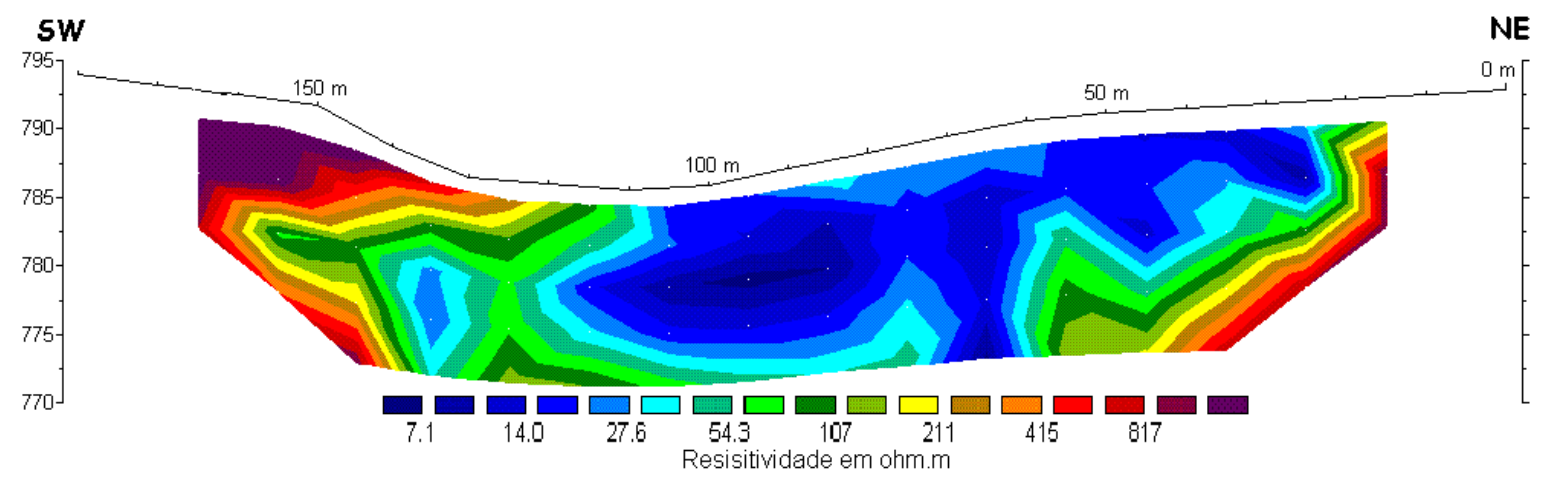


Dados de resistividade tratados no Surfer, linha 5 - 1995:

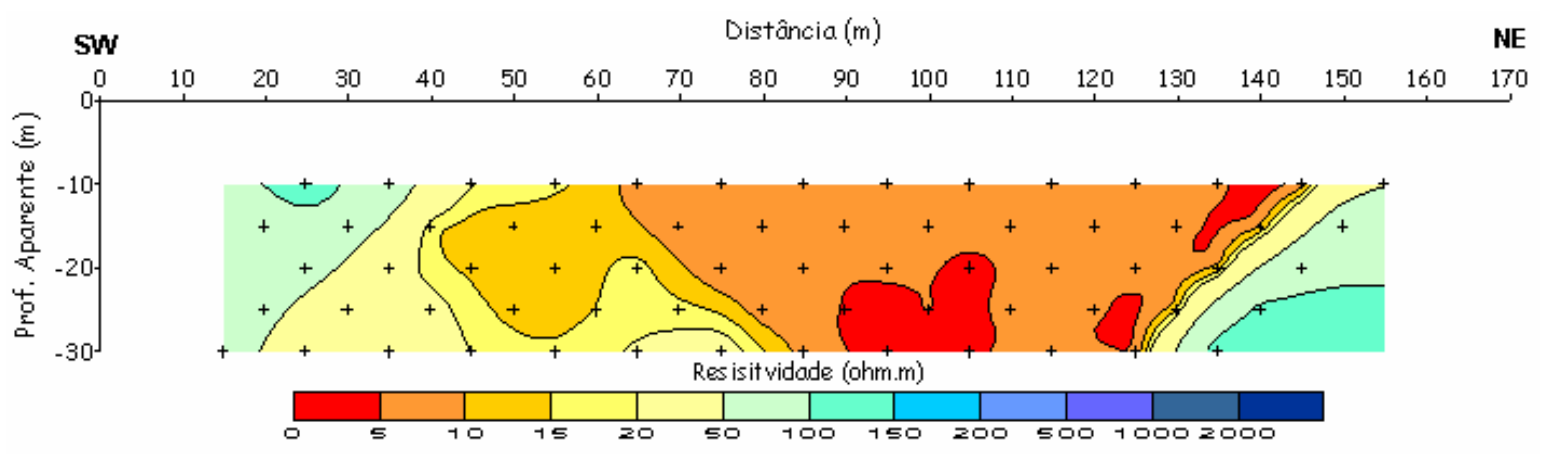

$\checkmark$ Dados de resistividade tratados no Res2dinv, linha 5 - 1995:

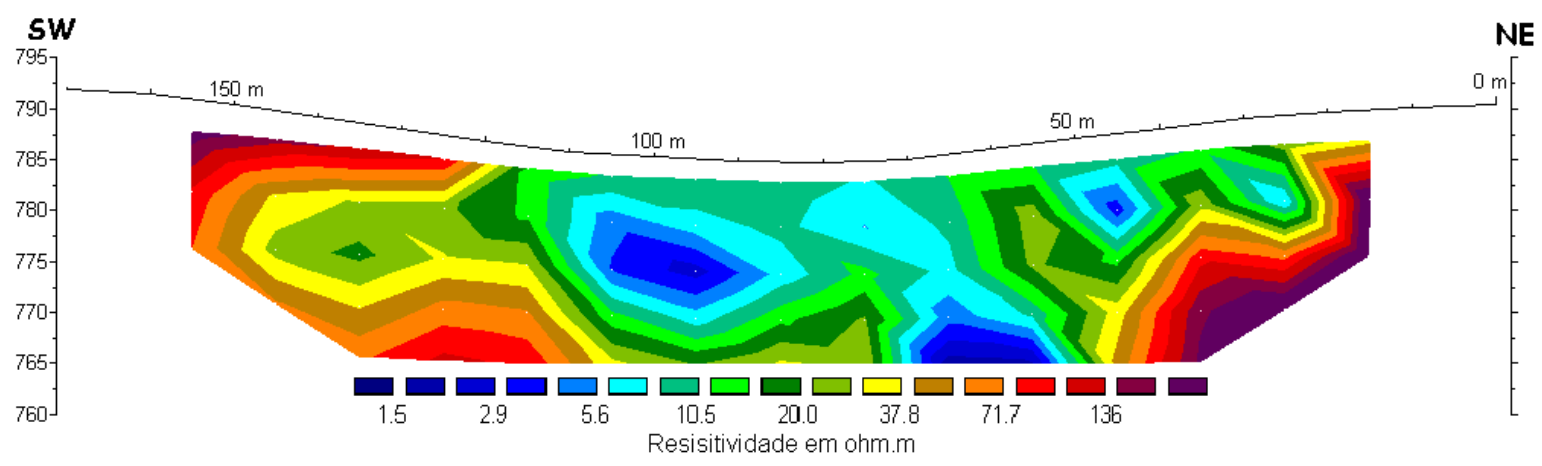

$\checkmark$ Dados cargabilidade tratados no Surfer, linha 3 - 2005:

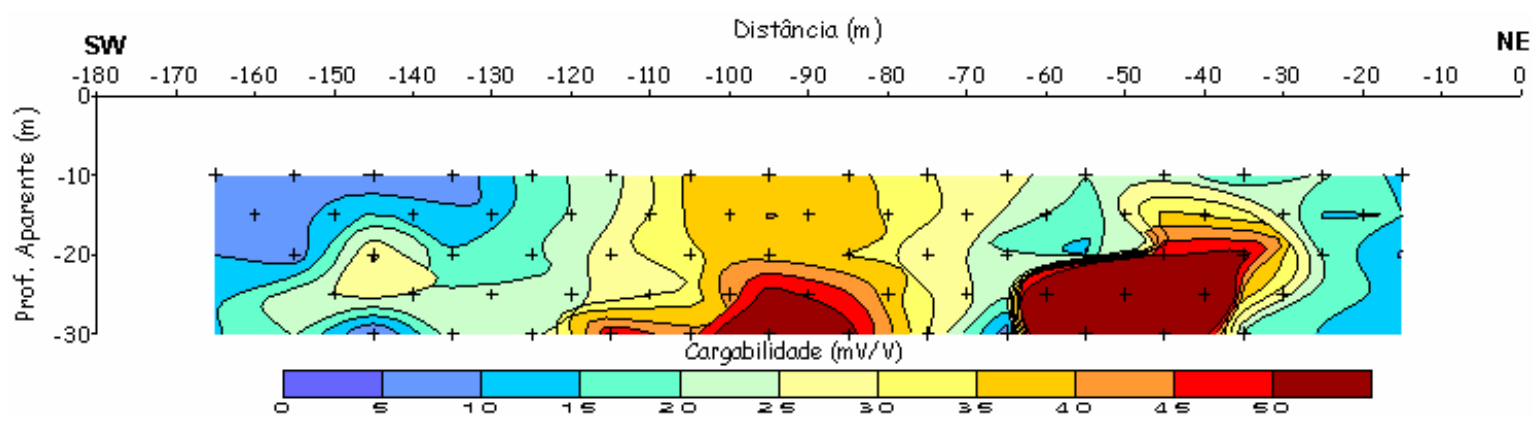


$\checkmark$ Dados de cargabilidade tratados no Res2dinv, linha 3 - 2005:

SW

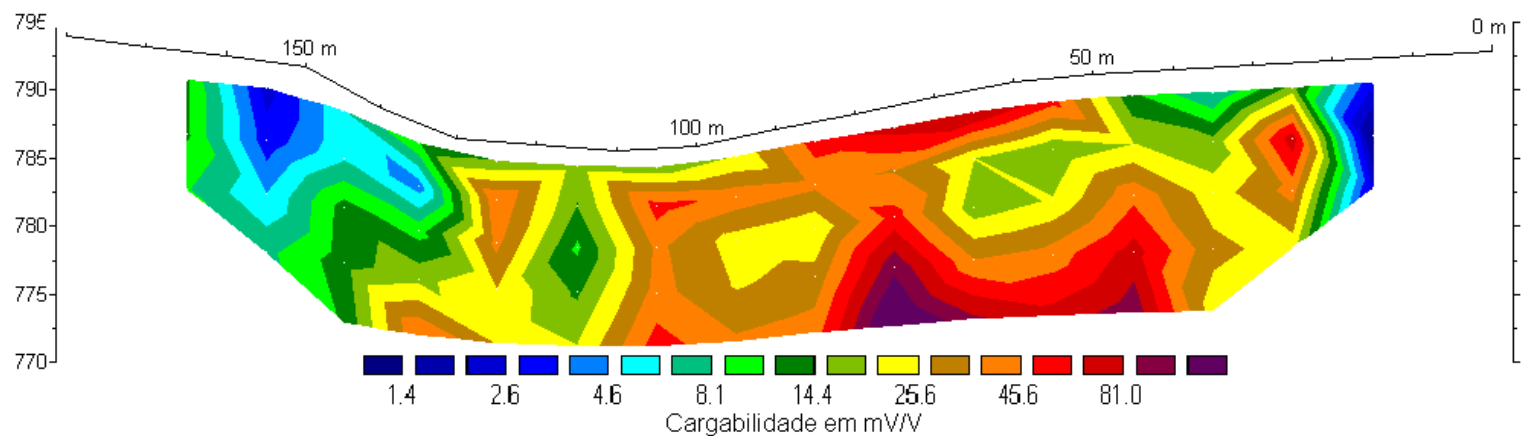




\section{Linha 4-2005}

$\checkmark$ Perfil linha $4-2005$ :

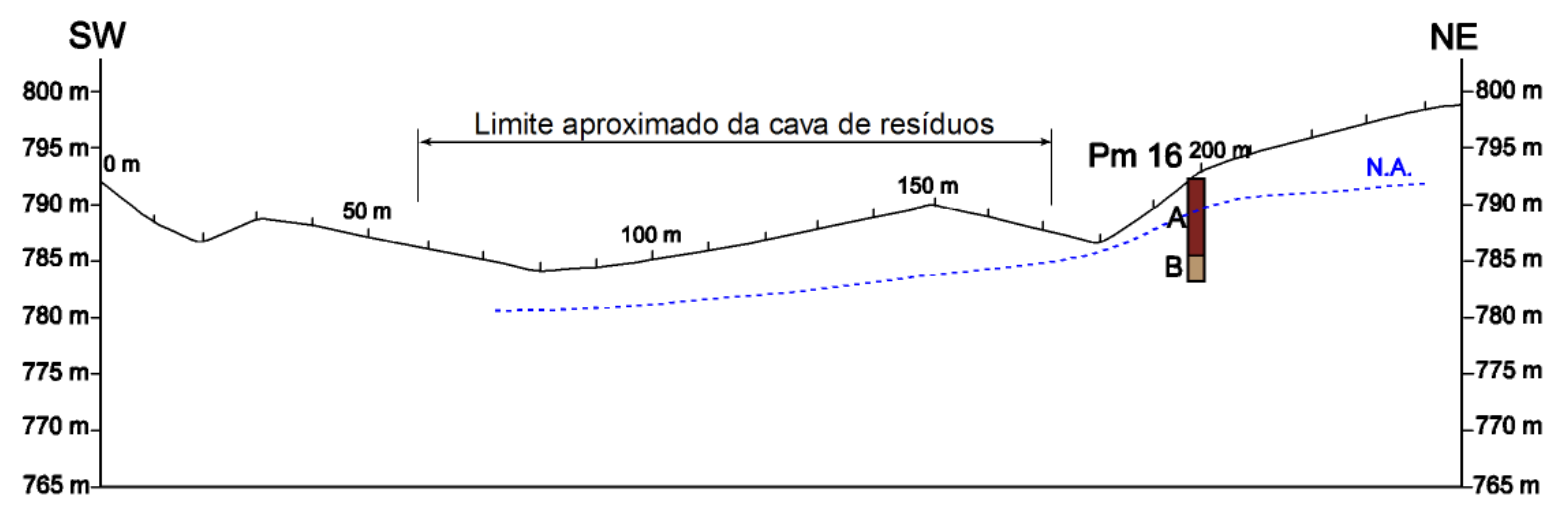

Pm 16

A- 0-7m: Areia fina siltosa vermelha

B- 7-9m: Areia fina siltosa vermelho claro

$\checkmark$ Dados de resistividade tratados no Surfer, linha 4 - 2005:

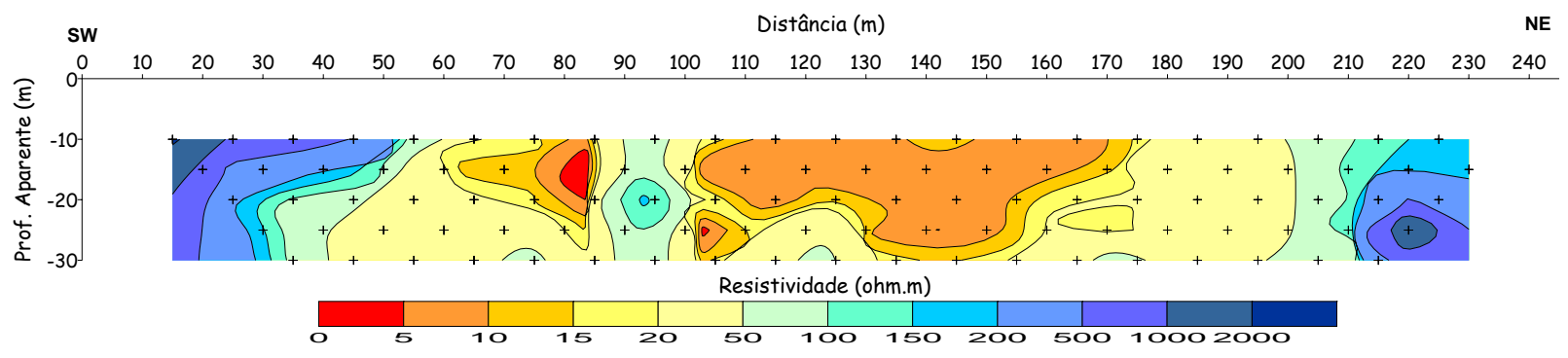

Dados de resistividade tratados no Res2dinv, linha 4 - 2005:

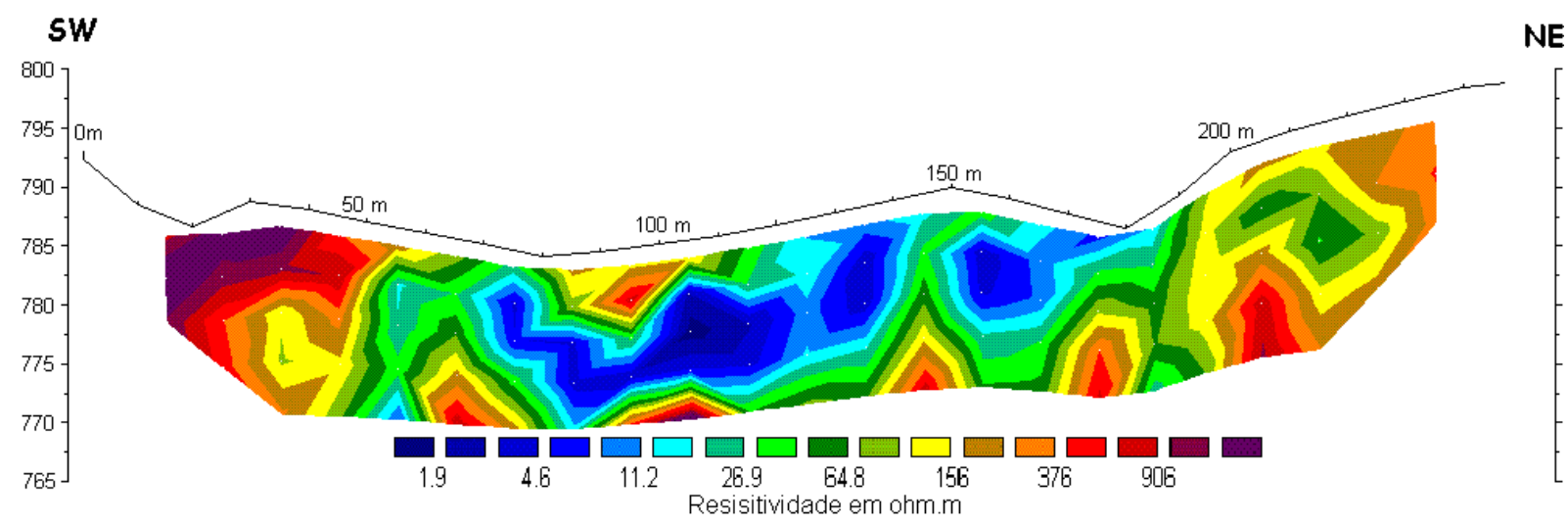


Dados de cargabilidade tratados no Surfer, linha 4 - 2005:

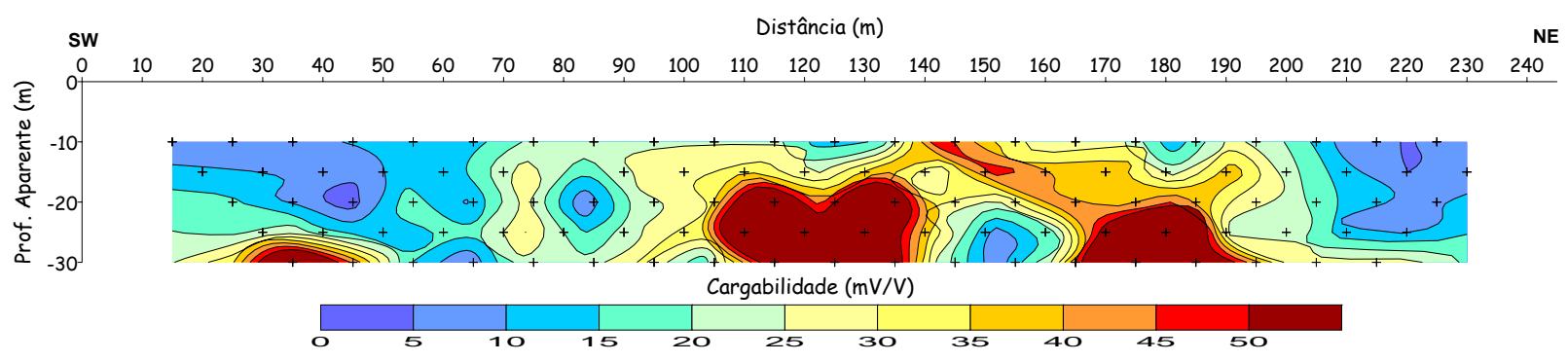

Dados de cargabilidade tratados no Res2dinv, linha 4 - 2005:

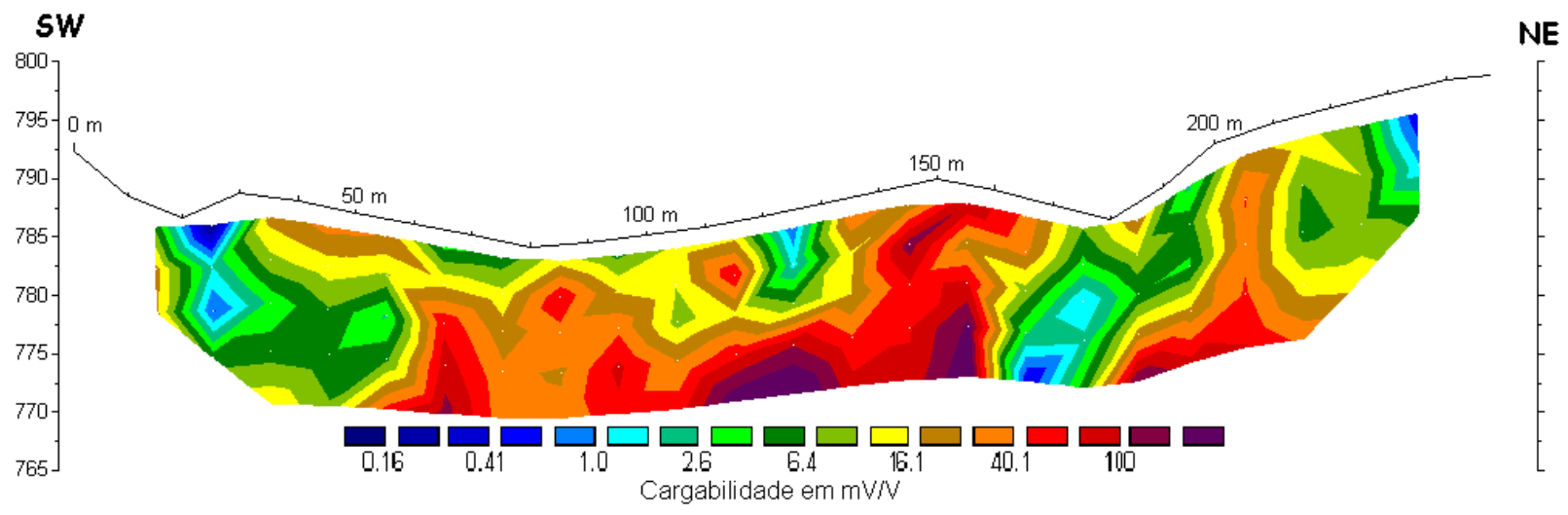




\section{Linha 5-2005 / 4-1995}

$\checkmark$ Perfil linha 5-2005/ 4 - 1995:

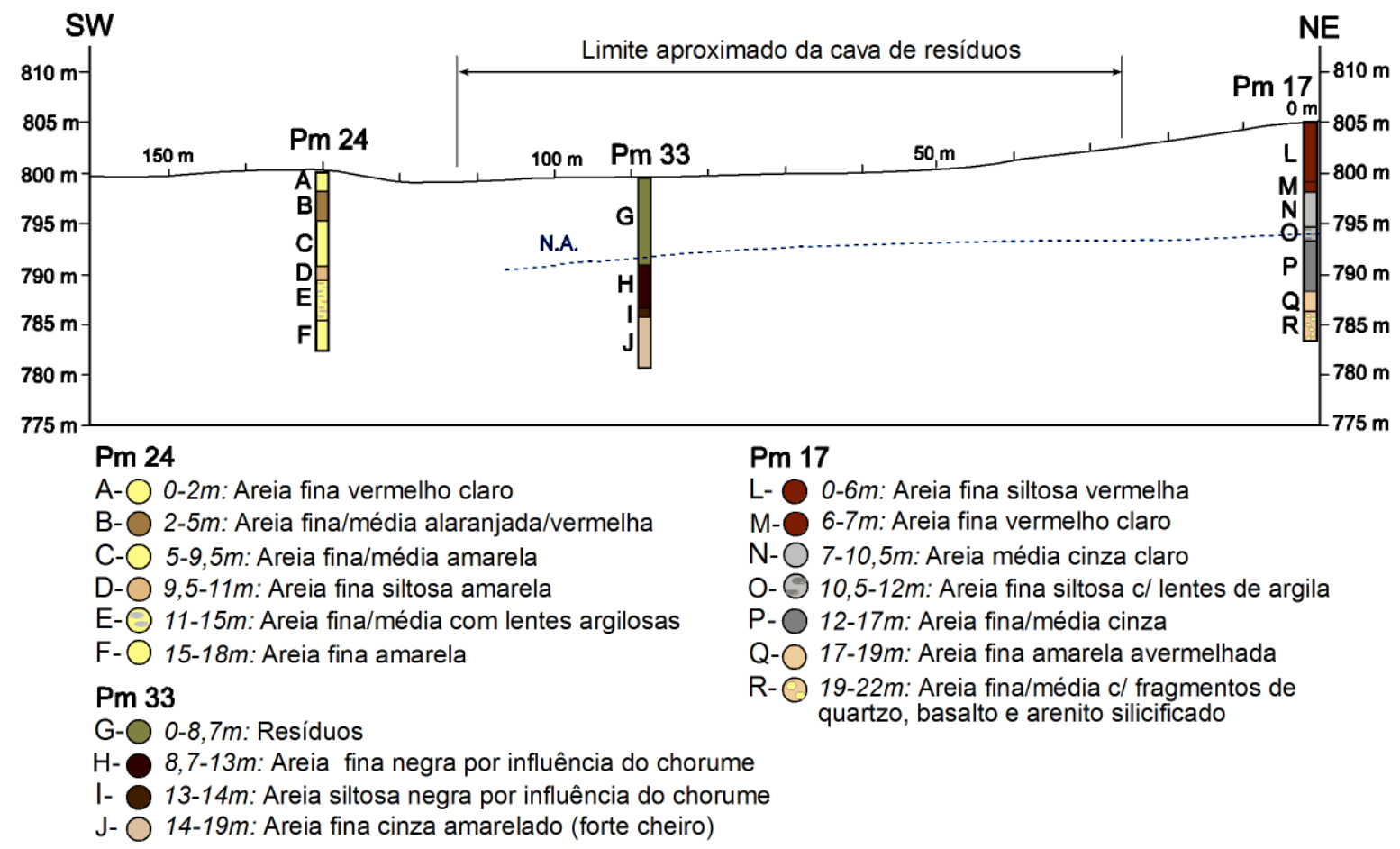

Dados de resistividade tratados no Surfer, linha 5 - 2005:

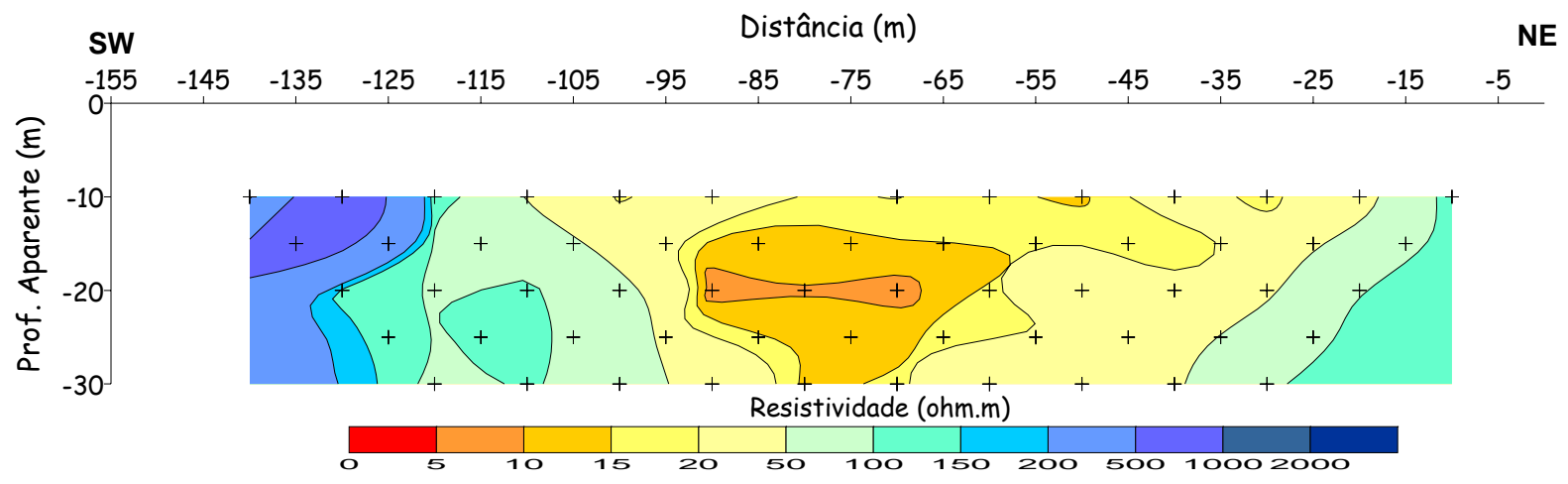


Dados de resistividade tratados no Res2dinv, linha 5 - 2005:

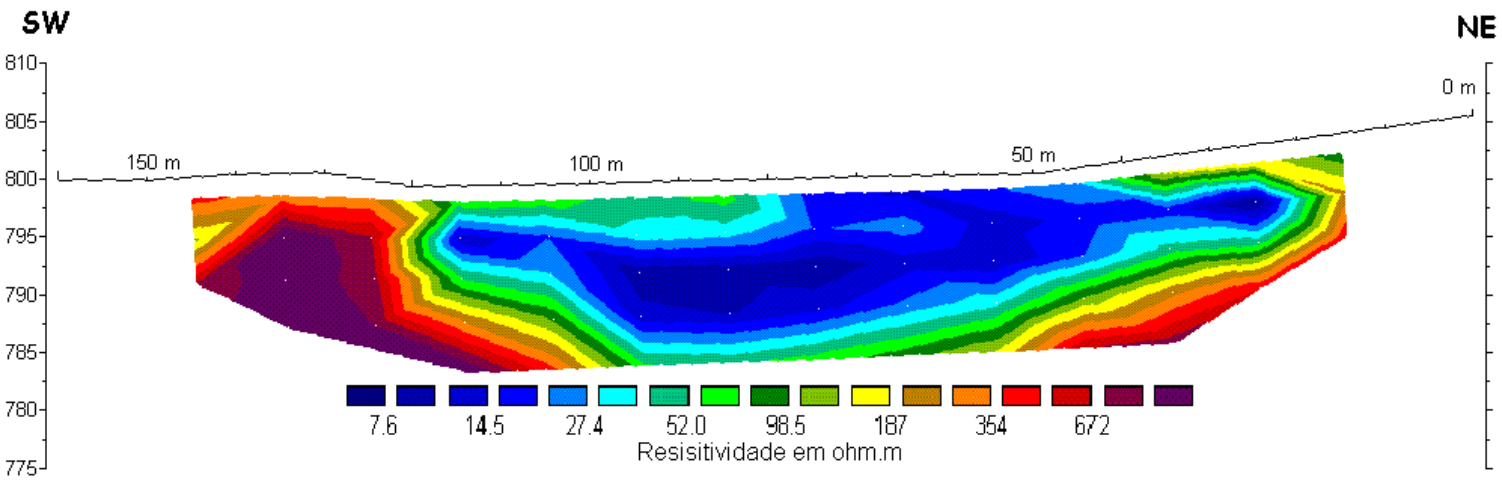

$\checkmark$ Dados de resistividade tratados no Surfer, linha 4 - 1995:

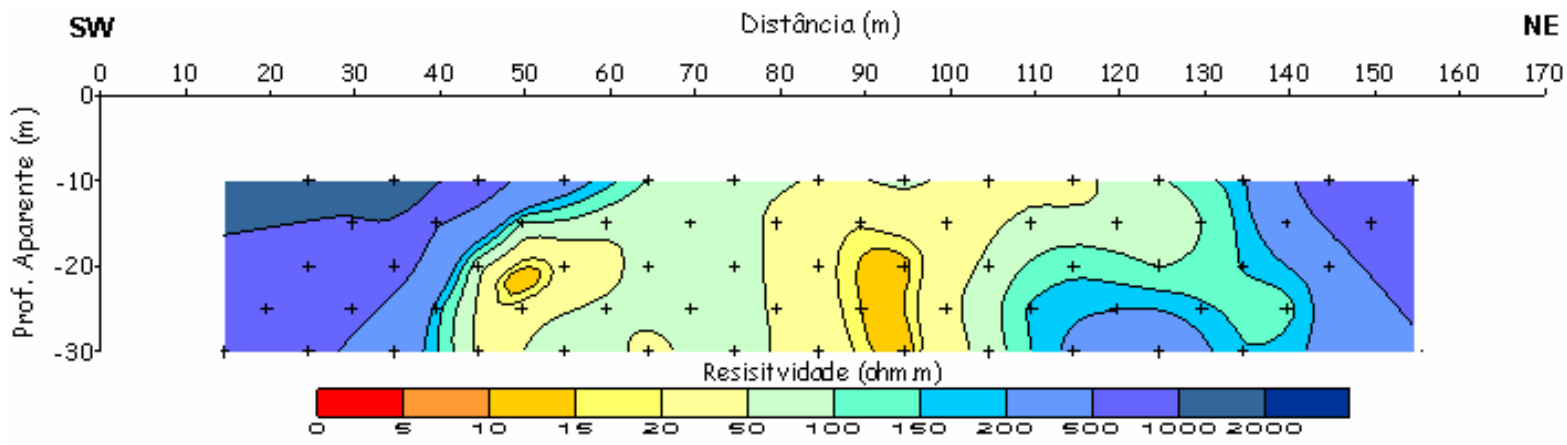

$\checkmark$ Dados de resistividade tratados no Res2dinv, linha 4 - 1995:

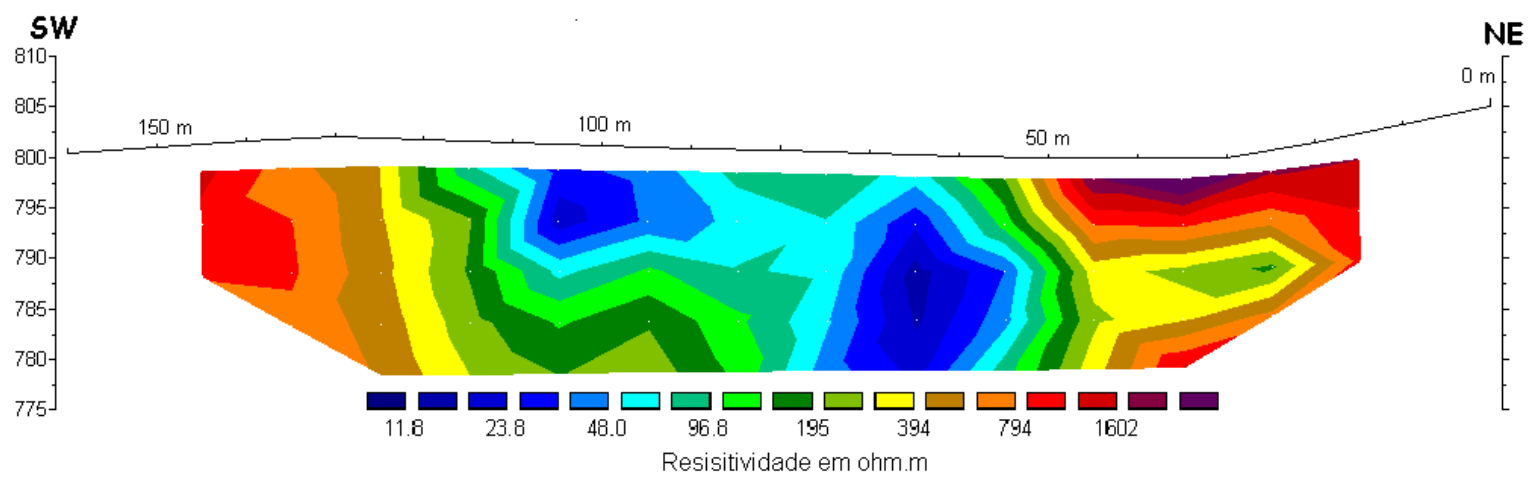


$\checkmark$ Dados de cargabilidade tratados no Surfer, linha 5 - 2005:

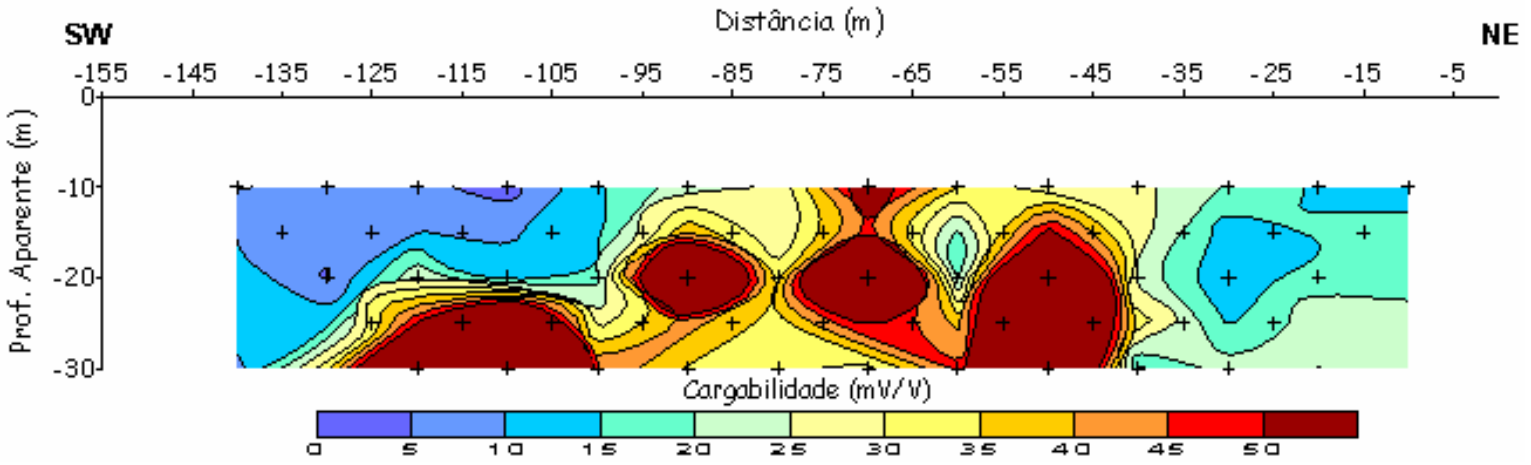

$\checkmark$ Dados de cargabilidade tratados no Res2dinv, linha 5 - 2005:

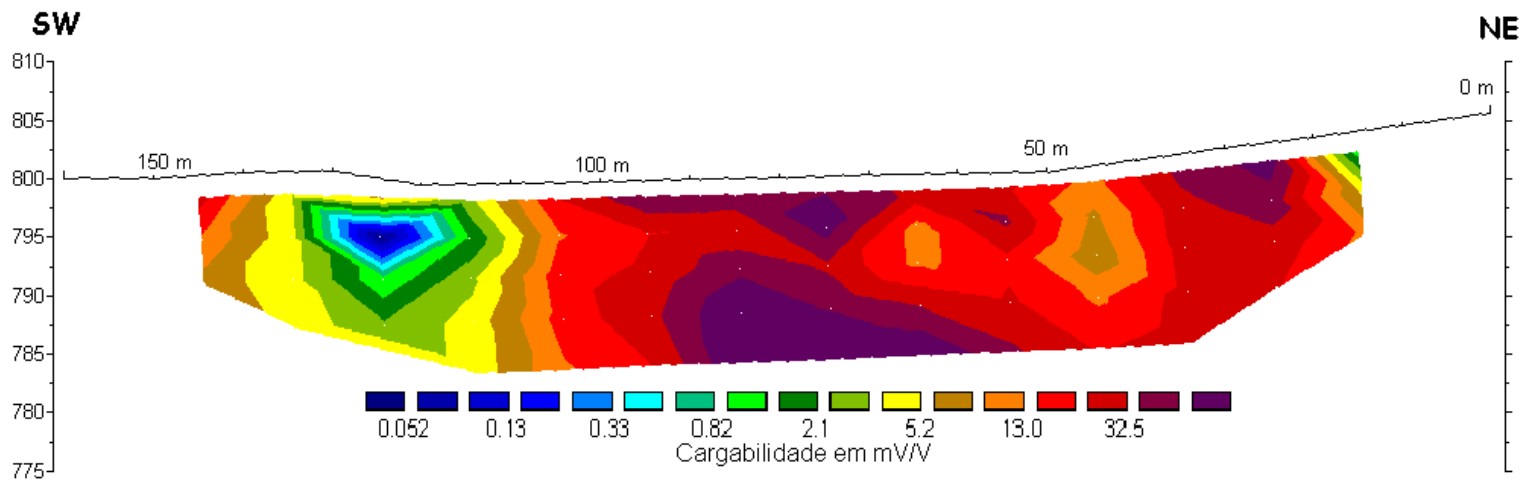




\section{Anexo I I}

\section{Planilhas de Campo - Ensaios de I nfiltração}




\section{ENSAIO DE INFILTRAÇÃO - DUPLO ANEL - R}

Data: 08 out 2005

Horário de início: 09:50

Horário final: 15:10

Horário das Coletas: 09:00/15:05/17:00 Profundidade da amostragem deformada: 11,00m

\begin{tabular}{|c|c|l|}
\hline \hline Anel & Raio $(\mathrm{cm})$ & Altura de Lâmina de Água: $9 \mathrm{~cm}$ \\
\hline Externo & 30 & Obs.: \\
\hline Interno & 15 & \\
\hline \hline
\end{tabular}

MEDIDAS DO ENSAIO

\begin{tabular}{|c|c|c|c|c|}
\hline Medida & Hora & Tempo (min) & Altura (Régua do balde) & Variação de alturc \\
\hline 1 & 09:50 & 0 & 0 & 0 \\
\hline 2 & $09: 51$ & 1 & 0,0080 & 0,0080 \\
\hline 3 & $09: 52$ & 2 & 0,0100 & 0,0020 \\
\hline 4 & $09: 53$ & 3 & 0,0120 & 0,0020 \\
\hline 5 & 09:54 & 4 & 0,0150 & 0,0030 \\
\hline 6 & $09: 55$ & 5 & 0,0170 & 0,0020 \\
\hline 7 & $09: 56$ & 6 & 0,0190 & 0,0020 \\
\hline 8 & $09: 57$ & 7 & 0,0200 & 0,0010 \\
\hline 9 & 09:58 & 8 & 0,0210 & 0,0010 \\
\hline 10 & $09: 59$ & 9 & 0,0230 & 0,0020 \\
\hline 11 & $10: 00$ & 10 & 0,0250 & 0,0020 \\
\hline 12 & $10: 15$ & 15 & 0,0330 & 0,0080 \\
\hline 13 & $10: 20$ & 20 & 0,0410 & 0,0080 \\
\hline 14 & $10: 25$ & 25 & 0,0500 & 0,0090 \\
\hline 15 & $10: 30$ & 30 & 0,0560 & 0,0060 \\
\hline 16 & $10: 35$ & 35 & 0,0640 & 0,0080 \\
\hline 17 & $10: 40$ & 40 & 0,0710 & 0,0070 \\
\hline 18 & $10: 50$ & 50 & 0,0850 & 0,0140 \\
\hline 19 & $11: 00$ & 60 & 0,1000 & 0,0150 \\
\hline 20 & $11: 10$ & 70 & 0,1140 & 0,0140 \\
\hline 21 & $11: 20$ & 80 & 0,1280 & 0,0140 \\
\hline 22 & $11: 30$ & 90 & 0,1430 & 0,0150 \\
\hline 23 & $11: 40$ & 100 & 0,1570 & 0,0140 \\
\hline 24 & $11: 50$ & 110 & 0,1700 & 0,0130 \\
\hline 25 & $12: 00$ & 120 & 0,1850 & 0,0150 \\
\hline 26 & $12: 10$ & 130 & 0,2000 & 0,0150 \\
\hline 27 & $12: 20$ & 140 & 0,2130 & 0,0130 \\
\hline 28 & $12: 30$ & 150 & 0,2280 & 0,0150 \\
\hline 29 & $12: 40$ & 160 & 0,2390 & 0,0110 \\
\hline 30 & $12: 50$ & 170 & 0,2550 & 0,0160 \\
\hline 31 & $13: 00$ & 180 & 0,2700 & 0,0150 \\
\hline 32 & $13: 10$ & 190 & 0,2850 & 0,0150 \\
\hline 33 & $13: 20$ & 200 & 0,3010 & 0,0160 \\
\hline 34 & $13: 30$ & 210 & 0,3150 & 0,0140 \\
\hline 35 & $13: 40$ & 220 & 0,3280 & 0,0130 \\
\hline 36 & $13: 50$ & 230 & 0,3420 & 0,0140 \\
\hline
\end{tabular}




\begin{tabular}{|l|l|l|l|l|}
\hline 37 & $14: 00$ & 240 & 0,3580 & 0,0160 \\
\hline 38 & $14: 10$ & 250 & 0,3730 & 0,0150 \\
\hline 39 & $14: 20$ & 260 & 0,3890 & 0,0160 \\
\hline 40 & $14: 30$ & 270 & 0,4030 & 0,0140 \\
\hline 41 & $14: 40$ & 280 & 0,4180 & 0,0150 \\
\hline 42 & $14: 50$ & 290 & 0,4330 & 0,0150 \\
\hline 43 & $15: 00$ & 300 & 0,4480 & 0,0150 \\
\hline 44 & $15: 10$ & 310 & 0,4630 & 0,0150 \\
\hline
\end{tabular}




\section{ENSAIO DE INFILTRAÇÃO - DUPLO ANEL - $S$}

\begin{tabular}{|c|c|c|c|c|}
\hline \multirow{2}{*}{\multicolumn{3}{|c|}{$\begin{array}{l}\text { Data: } 09 \text { out } 2005 \\
\text { Horário de início: } 09: 55\end{array}$}} & \multicolumn{2}{|c|}{ Localização: Lixão desativado de São Carlos } \\
\hline & & & \multicolumn{2}{|l|}{ Coordenadas UTM: 210.203} \\
\hline \multicolumn{3}{|c|}{ Horário final: $\quad 13: 20$} & \multicolumn{2}{|c|}{7.555 .085} \\
\hline \multirow{2}{*}{\multicolumn{2}{|c|}{ Horário das Coletas: }} & 09:00/13:25/15:20 & \multicolumn{2}{|c|}{ Profundidade da amostragem deformada: $3,80 \mathrm{~m}$} \\
\hline & & \multicolumn{3}{|c|}{ DADOS CONSTANTES } \\
\hline Anel & Raio $(\mathrm{cm})$ & \multirow{3}{*}{\multicolumn{3}{|c|}{$\begin{array}{l}\text { Altura de Lâmina de Água: } 10 \mathrm{~cm} \\
\begin{array}{l}\text { Obs.: ponto dentro da erosão } \\
\text { fim da amostragem: encontro da rocha. }\end{array} \\
\end{array}$}} \\
\hline Externo & 30 & & & \\
\hline Interno & 15 & & & \\
\hline \multicolumn{5}{|c|}{ MEDIDAS DO ENSAIO } \\
\hline Medida & Hora & Tempo (min) & Altura (Régua do balde) & Variação de altura \\
\hline 1 & $09: 55$ & 0 & 0,0 & 0 \\
\hline 2 & 09:56 & 1 & 0,012 & 0,0120 \\
\hline 3 & 09:57 & 2 & 0,020 & 0,0080 \\
\hline 4 & 09:58 & 3 & 0,026 & 0,0060 \\
\hline 5 & 09:59 & 4 & 0,031 & 0,0050 \\
\hline 6 & $10: 00$ & 5 & 0,035 & 0,0040 \\
\hline 7 & $10: 01$ & 6 & 0,040 & 0,0050 \\
\hline 8 & $10: 02$ & 7 & 0,043 & 0,0030 \\
\hline 9 & $10: 03$ & 8 & 0,049 & 0,0060 \\
\hline 10 & 10:04 & 9 & 0,051 & 0,0020 \\
\hline 11 & $10: 05$ & 10 & 0,056 & 0,0050 \\
\hline 12 & $10: 10$ & 15 & 0,076 & 0,0200 \\
\hline 13 & $10: 15$ & 20 & 0,094 & 0,0180 \\
\hline 14 & $10: 20$ & 25 & 0,113 & 0,0190 \\
\hline 15 & $10: 25$ & 30 & 0,128 & 0,0150 \\
\hline 16 & $10: 30$ & 35 & 0,147 & 0,0190 \\
\hline 17 & $10: 35$ & 40 & 0,163 & 0,0160 \\
\hline 18 & $10: 45$ & 50 & 0,199 & 0,0360 \\
\hline 19 & $10: 55$ & 60 & 0,232 & 0,0330 \\
\hline 20 & 11:05 & 70 & 0,266 & 0,0340 \\
\hline 21 & $11: 15$ & 80 & 0,299 & 0,0330 \\
\hline 22 & $11: 25$ & 90 & 0,328 & 0,0290 \\
\hline 23 & $11: 35$ & 100 & 0,369 & 0,0410 \\
\hline 24 & $11: 45$ & 110 & 0,428 & 0,0590 \\
\hline 25 & $11: 55$ & 120 & 0,452 & 0,0240 \\
\hline 26 & $12: 05$ & 130 & 0,500 & 0,0480 \\
\hline 27 & $12: 15$ & 140 & 0,544 & 0,0440 \\
\hline 28 & $12: 25$ & 150 & 0,590 & 0,0460 \\
\hline 29 & $12: 35$ & 160 & 0,630 & 0,0400 \\
\hline 30 & $12: 45$ & 170 & 0,680 & 0,0500 \\
\hline 31 & $12: 55$ & 180 & 0,723 & 0,0430 \\
\hline 32 & $13: 05$ & 190 & 0,768 & 0,0450 \\
\hline 33 & $13: 15$ & 200 & 0,813 & 0,0450 \\
\hline 34 & $13: 25$ & 210 & 0,858 & 0,0450 \\
\hline
\end{tabular}




\section{ENSAIO DE INFILTRAÇÃO - DUPLO ANEL - T}

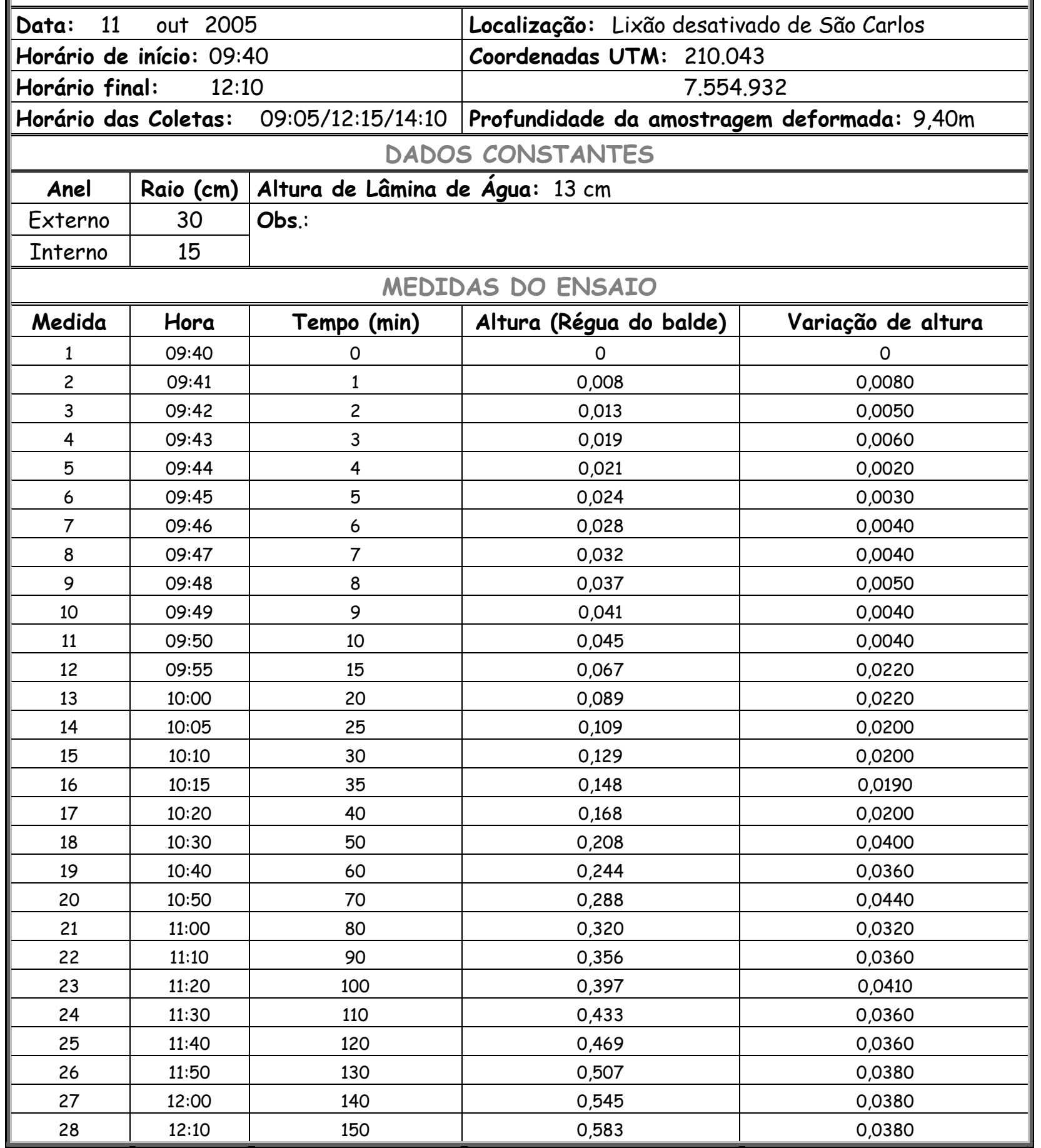




\section{ENSAIO DE INFILTRAÇÃO - DUPLO ANEL - $U$}

\begin{tabular}{|c|c|c|c|c|}
\hline \multirow{2}{*}{\multicolumn{3}{|c|}{$\begin{array}{l}\text { Data: } 11 \text { out } 2005 \\
\text { Horário de início: } 14: 00\end{array}$}} & \multicolumn{2}{|c|}{ Localização: Lixão desativado de São Carlos } \\
\hline & & & \multicolumn{2}{|c|}{ Coordenadas UTM: 210.088} \\
\hline \multicolumn{3}{|c|}{ Horário final: $\quad 15: 30$} & \multicolumn{2}{|c|}{7.554 .996} \\
\hline \multirow{2}{*}{\multicolumn{2}{|c|}{ Horário das Coletas: }} & $13: 30 / 15: 30 / 17: 30$ & \multicolumn{2}{|c|}{ Profundidade da amostragem deformada: $0,20 \mathrm{~m}$} \\
\hline & & \multicolumn{3}{|c|}{ DADOS CONSTANTES } \\
\hline Anel & Raio $(\mathrm{cm})$ & \multirow{3}{*}{\multicolumn{3}{|c|}{$\begin{array}{l}\text { Altura de Lâmina de Água: } 15 \mathrm{~cm} \\
\text { Obs.: Ponto em cima do lixão } \\
\text { Pequena profundidade amostrada devido ao encontro de lixo }\end{array}$}} \\
\hline Externo & 30 & & & \\
\hline Interno & 15 & & & \\
\hline \multicolumn{5}{|c|}{ MEDIDAS DO ENSAIO } \\
\hline Medida & Hora & Tempo (min) & Altura (Régua do balde) & Variação de altura \\
\hline 1 & $14: 00$ & 0 & 0 & 0 \\
\hline 2 & $14: 01$ & 1 & 0,008 & 0,0080 \\
\hline 3 & $14: 02$ & 2 & 0,012 & 0,0040 \\
\hline 4 & 14:03 & 3 & 0,015 & 0,0030 \\
\hline 5 & 14:04 & 4 & 0,017 & 0,0020 \\
\hline 6 & $14: 05$ & 5 & 0,019 & 0,0020 \\
\hline 7 & $14: 06$ & 6 & 0,021 & 0,0020 \\
\hline 8 & 14:07 & 7 & 0,022 & 0,0010 \\
\hline 9 & $14: 08$ & 8 & 0,023 & 0,0010 \\
\hline 10 & $14: 09$ & 9 & 0,024 & 0,0010 \\
\hline 11 & $14: 10$ & 10 & 0,025 & 0,0010 \\
\hline 12 & $14: 15$ & 15 & 0,029 & 0,0040 \\
\hline 13 & $14: 20$ & 20 & 0,033 & 0,0040 \\
\hline 14 & $14: 25$ & 25 & 0,036 & 0,0030 \\
\hline 15 & $14: 3$ & 30 & 0,040 & 0,0040 \\
\hline 16 & $14: 35$ & 35 & 0,043 & 0,0030 \\
\hline 17 & $14: 40$ & 40 & 0,046 & 0,0030 \\
\hline 18 & $14: 50$ & 50 & 0,053 & 0,0070 \\
\hline 19 & 13:00 & 60 & 0,058 & 0,0050 \\
\hline 20 & $13: 10$ & 70 & 0,063 & 0,0050 \\
\hline 21 & $13: 20$ & 80 & 0,068 & 0,0050 \\
\hline 22 & $13: 30$ & 90 & 0,073 & 0,0050 \\
\hline
\end{tabular}




\section{ENSAIO DE INFILTRAÇÃO - DUPLO ANEL - V}

\begin{tabular}{|c|c|c|c|c|}
\hline \multirow{2}{*}{\multicolumn{3}{|c|}{$\begin{array}{l}\text { Data: } 11 \text { out } 2005 \\
\text { Horário de início: } 15: 50\end{array}$}} & \multicolumn{2}{|c|}{ Localização: Lixão desativado de São Carlos } \\
\hline & & & \multicolumn{2}{|c|}{ Coordenadas UTM: 209.960} \\
\hline \multicolumn{3}{|c|}{ Horário final: $\quad 17: 20$} & \multicolumn{2}{|c|}{7.555 .121} \\
\hline \multicolumn{2}{|c|}{ Horário das Coletas: } & $13: 30 / 15: 30 / 19: 00$ & \multicolumn{2}{|c|}{ Profundidade da amostragem deformada: $0,20 \mathrm{~m}$} \\
\hline \multicolumn{5}{|c|}{ DADOS CONSTANTES } \\
\hline Anel & Raio $(\mathrm{cm})$ & \multirow{3}{*}{\multicolumn{3}{|c|}{$\begin{array}{l}\text { Altura de Lâmina de Água: } 15 \mathrm{~cm} \\
\text { Obs.: Ponto em cima do lixão } \\
\text { Pequena profundidade amostrada devido ao encontro de lixo }\end{array}$}} \\
\hline Externo & 30 & & & \\
\hline Interno & 15 & & & \\
\hline \multicolumn{5}{|c|}{ MEDIDAS DO ENSAIO } \\
\hline Medida & Hora & Tempo (min) & Altura (Régua do balde) & Variação de altura \\
\hline 1 & $15: 50$ & 0 & 0 & 0 \\
\hline 2 & $15: 51$ & 1 & 0,008 & 0,0080 \\
\hline 3 & $15: 52$ & 2 & 0,011 & 0,0030 \\
\hline 4 & $15: 53$ & 3 & 0,015 & 0,0040 \\
\hline 5 & $15: 54$ & 4 & 0,019 & 0,0040 \\
\hline 6 & $15: 55$ & 5 & 0,022 & 0,0030 \\
\hline 7 & $15: 56$ & 6 & 0,026 & 0,0040 \\
\hline 8 & $15: 57$ & 7 & 0,028 & 0,0020 \\
\hline 9 & $15: 58$ & 8 & 0,031 & 0,0030 \\
\hline 10 & $15: 59$ & 9 & 0,034 & 0,0030 \\
\hline 11 & $16: 00$ & 10 & 0,038 & 0,0040 \\
\hline 12 & $16: 05$ & 15 & 0,048 & 0,0100 \\
\hline 13 & $16: 10$ & 20 & 0,058 & 0,0100 \\
\hline 14 & $16: 15$ & 25 & 0,064 & 0,0060 \\
\hline 15 & $16: 20$ & 30 & 0,071 & 0,0070 \\
\hline 16 & $16: 25$ & 35 & 0,078 & 0,0070 \\
\hline 17 & $16: 30$ & 40 & 0,087 & 0,0090 \\
\hline 18 & $16: 40$ & 50 & 0,099 & 0,0120 \\
\hline 19 & $16: 50$ & 60 & 0,111 & 0,0120 \\
\hline 20 & $17: 00$ & 70 & 0,122 & 0,0110 \\
\hline 21 & $17: 10$ & 80 & 0,133 & 0,0110 \\
\hline 22 & $17: 20$ & 90 & 0,144 & 0,0110 \\
\hline
\end{tabular}




\section{Anexo IV}

\section{Planilhas de Cálculo e Curvas de Infiltração - Ensaios de Infiltração}




\begin{tabular}{|c|c|c|c|c|c|c|c|c|c|c|c|}
\hline $\begin{array}{c}\Delta H \\
(\mathbf{m})\end{array}$ & $\begin{array}{c}t \\
(\text { seg })\end{array}$ & $\underset{(\mathrm{m})}{\mathrm{H}}$ & $\begin{array}{c}Q \\
(m 3 / s)\end{array}$ & $\begin{array}{l}\text { Zw } \\
(\mathrm{m})\end{array}$ & $\underset{(\mathrm{m} 2)}{A}$ & $\begin{array}{c}K \\
(m / s)\end{array}$ & $\begin{array}{c}t \\
(\min )\end{array}$ & $\begin{array}{c}\text { DH } \\
(\mathrm{mm})\end{array}$ & $\begin{array}{c}t \\
\text { (h) }\end{array}$ & $\begin{array}{c}\text { Taxa I } \\
(\mathrm{mm} / \mathrm{h})\end{array}$ & $\begin{array}{l}\Delta h \\
(\mathrm{~m})\end{array}$ \\
\hline 0,000 & 0 & U & 0 & 8 & 07065 & 0,000000000 & 0 & 0 & 0 & 0 & 0 \\
\hline & 60 & & 00000942 & 8 & & 0,000126984 & 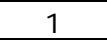 & 8 & 017 & 480,000 & \\
\hline 0,010 & 20 & & 00000589 & 1,8 & 07065 & 0,0000 & 2 & 10 & 033 & 300,000 & \\
\hline 0,012 & 180 & 09 & 0,00000471 & 1,8 & \begin{tabular}{|l|l|}
0,07065 \\
\end{tabular} & 0,000063492 & 3 & 12 & 0,050 & 240,000 &, 0020 \\
\hline 0,015 & 240 & & 0,00000442 & 1,8 & \begin{tabular}{|l|}
0,07065 \\
\end{tabular} & 0,000059524 & 4 & 15 & 067 & 225,000 & \\
\hline & & & & 1,8 & & 0,000 & 5 & 17 & & 204,000 & \\
\hline & 360 & & & 1,8 & & 0265 & 6 & 19 & & 190,000 & \\
\hline & 420 & 0,09 & 0336 & 1,8 & 065 & 0,000045351 & 7 & 20 & 117 & 171,429 & \\
\hline 0,021 & 480 & 0,09 & 00309 & 1,8 & & 0,000041667 & 8 & 21 & 133 & 157,500 & \\
\hline & 540 & & & 1,8 & & 0564 & 9 & 23 & & 153,333 & \\
\hline & 0 & & & 1,8 & & 683 & & 25 & & 50,000 & \\
\hline & 900 & & & 1,8 & & 4921 & 15 & 33 & 250 & 132,000 & \\
\hline & 1200 & & 241 & 1,8 & & 2540 & 20 & 41 & & 123,000 & \\
\hline & 1500 & & & 1,8 & & & 25 & 50 & & & \\
\hline & 00 & & & 8 & & & & 30 & & 112,000 & \\
\hline & 2100 & & & 1,8 & & 9025 & 35 & 64 & 83 & 109,714 & \\
\hline & 2400 & & & 1,8 & & 8175 & 40 & 71 & & 106,500 & \\
\hline 0085 & 3000 & & & 1,8 & & 6984 & & 85 & & 102,000 & \\
\hline & & & & 1,8 & & & & & & 100, & \\
\hline & 4200 & & & 1,8 & 65 & 850 & & & 67 & 97,714 & \\
\hline & 4800 & & & 1,8 & & 5397 & 80 & & 33 & 96,000 & \\
\hline 0,143 & 5400 & & & 1,8 & & 5220 & & & 1,500 & 95,333 & \\
\hline & & & & 1,8 & & 921 & & & & & \\
\hline & 6600 & & & 1,8 & & 0 & & & & 27 & \\
\hline & 7200 & 0 & & 1,8 & & 4471 & 12 & 1 & 00 & 92,500 & \\
\hline & 7800 & & & 1,8 & & 4420 & & & & 92,308 & \\
\hline & & & & 1,8 & & & & & & & \\
\hline & & & & 1,8 & & & & & & & \\
\hline 0 & 00 & 0 & 76 & 1,8 & & 10 & 1 & 7 & 67 & 25 & \\
\hline & 10200 & & & 1,8 & & & & & 2,833 & & \\
\hline & 10800 & & & 1,8 & & & & & & & \\
\hline & & & & & & & & & & & \\
\hline 0,3 & 12 & 00 & 77 & 1,8 & 65 & 0 , & 7 & 3 & 33 & 00 & 60 \\
\hline & 12600 & & 0177 & 1,8 & & 0,000023810 & & & 3,500 & 90,000 & \\
\hline & 13200 & & 0176 & 1,8 & 0,07065 & 0,000023665 & & & 3,667 & & \\
\hline & & & & 1,8 & & & & & & & \\
\hline 0,3 & 14400 & 0,09 & 76 & 1,8 & 65 & 3677 & 200 & 358 & 4,000 & 00 & 60 \\
\hline 0,373 & 15000 & 0,09 & 0176 & 1,8 & 065 & 0,000023683 & & 373 & 4,167 & 89,520 & 150 \\
\hline 0,389 & 15600 & 0,0 & 00176 & 1,8 & 0,07065 & 0,000023748 & 26 & 389 & 4,333 & 89,769 & \\
\hline & 16200 & 0,09 & & 1,8 & & 023692 & 270 & 403 & & & \\
\hline 0,418 & 16800 & 0,09 & 00176 & 1,8 & \begin{tabular}{|l}
0,07065 \\
\end{tabular} & 0,000023696 & 280 & 418 & 4,667 & 89,571 & 0,0150 \\
\hline 0,433 & 17400 & 0,09 & 00176 & 1,8 & 0,07065 & 0,000023700 & 290 & 433 & 4,833 & 89,586 & 0,0150 \\
\hline 0,448 & 18000 & 0,0 & 0,00000176 & 1,8 & 0,07065 & 0,000023704 & 300 & 448 & 5,000 & 89,600 & 0,0150 \\
\hline 0,463 & 18600 & 0,09 & 0,00000176 & 1,8 & 0,07065 & 0,000023707 & 310 & 463 & 5,167 & 89,613 & 0,0150 \\
\hline
\end{tabular}




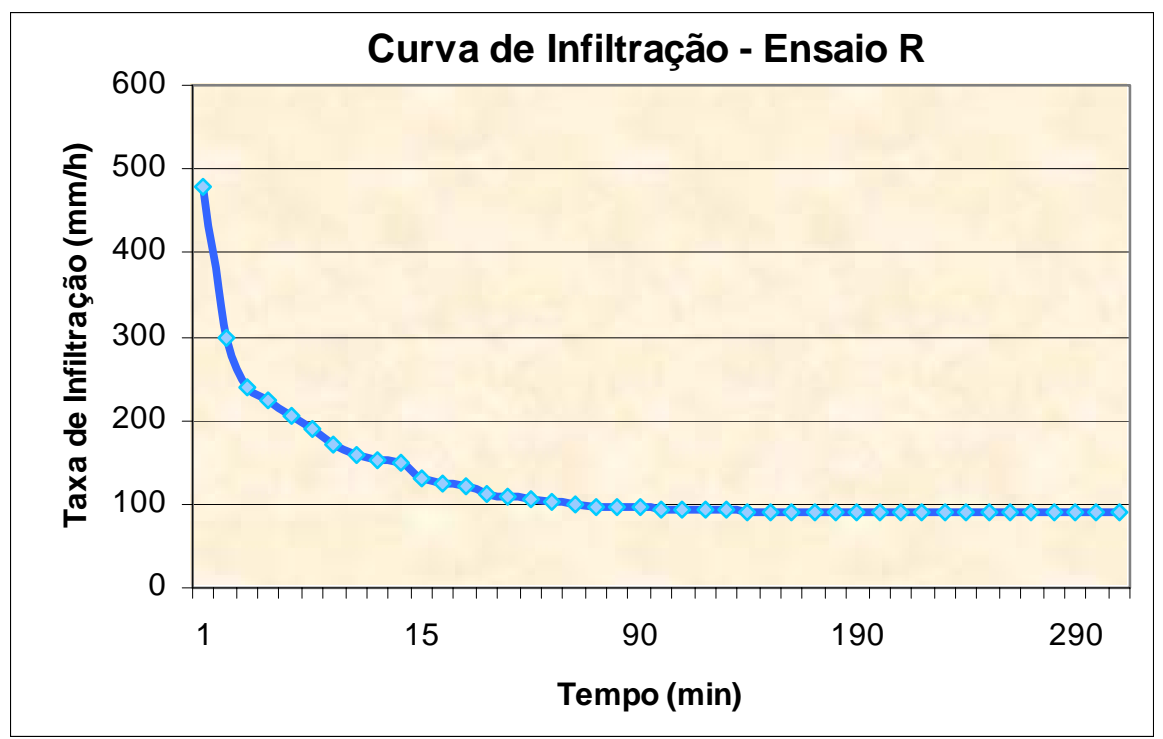




\begin{tabular}{|c|c|c|c|c|c|c|c|c|c|c|c|}
\hline \multicolumn{12}{|c|}{ Ensaio de Inffltração - IAD - Ensaio S (solo) } \\
\hline $\begin{array}{l}\Delta \mathbf{H} \\
(\mathbf{m})\end{array}$ & $\begin{array}{c}\mathbf{t} \\
(\mathbf{s e g})\end{array}$ & $\begin{array}{c}\mathbf{H} \\
(\mathbf{m})\end{array}$ & $\begin{array}{c}Q \\
(\mathrm{~m} 3 / \mathrm{s})\end{array}$ & $\begin{array}{l}\mathbf{Z w} \\
(\mathbf{m})\end{array}$ & $\begin{array}{c}\text { A } \\
(\mathbf{m} 2)\end{array}$ & $\begin{array}{c}K \\
(\mathrm{~m} / \mathrm{s})\end{array}$ & $\begin{array}{c}\mathbf{t} \\
(\mathbf{m i n})\end{array}$ & $\begin{array}{c}\text { DH } \\
(\mathbf{m m})\end{array}$ & $\begin{array}{c}\text { t } \\
(\mathbf{h})\end{array}$ & $\begin{array}{c}\text { Taxa I } \\
(\mathrm{mm} / \mathrm{h})\end{array}$ & $\begin{array}{l}\Delta \mathbf{~ h} \\
(\mathbf{m})\end{array}$ \\
\hline 0,0 & 0 & & 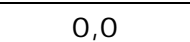 & & & 0,0 & 0 & 0 & 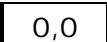 & 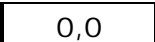 & 0 \\
\hline, 012 & 60 & & 00001413 & & & 0,000181818 & 1 & 12 &, 017 & 720,000 & \\
\hline & 120 & & 00001178 & 1,0 & 07065 & 0,00015 & 2 & 20 & 033 & 600,000 & \\
\hline 026 & 180 & 0 & 21 & 1,0 & 07065 & 0,000131313 & 3 & 26 & 050 & 520,000 & \\
\hline 031 & 240 & 10 & 0913 & 1,0 & & 0,000117424 & 4 & 31 & 0,067 & 465,000 & \\
\hline & 300 & & & 1,0 & & 61 & 5 & 35 & 83 & 420,000 & \\
\hline & 360 & & & 0 & & & 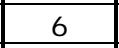 & 40 & & 400,000 & \\
\hline & 420 & & & 1,0 & & 0093074 & 7 & 43 & 117 & 368,571 & \\
\hline & 480 & & 0721 & 1,0 & & 0,000092803 & 8 & 49 & 133 & 367,500 & \\
\hline & 540 & & & 1,0 & & 0,0000 & 9 & 51 & & & \\
\hline & & & & & & & 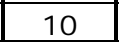 & J & & 0 & \\
\hline & 900 & & & 1,0 & & 68 & & 76 & 50 & 000 & \\
\hline & 1200 & & & 1,0 & & 0071212 & 20 & 94 & 33 & 282,000 & \\
\hline 13 & 1500 & & & 70 & & 0,000068485 & 70 & 113 & 417 & 271,200 & \\
\hline & 00 & & & & & & & & & 000 & \\
\hline & 2100 & & & 1,0 & & 36 & & & 83 & 000 & \\
\hline & 2400 & & & 1,0 & & 1742 & 40 & 16 & 67 & 500 & \\
\hline 99 & 3000 & 0,10 & & 1,0 & & 0060303 & 50 & & 33 & 238,800 & \\
\hline & 3600 & & & & & & & & & 00 & \\
\hline & 4200 & & & 1,0 & & & & & & 00 & \\
\hline 99 & 4800 & 0,10 & 40 & 1,0 & & 29 & 80 & 2 & 33 & 250 & \\
\hline & 5400 & 0,10 & & 1,0 & & 19 & 90 & & & 218,667 & \\
\hline & 6000 & & & & & & & & & 221,400 & \\
\hline & & & & & & & & & & & \\
\hline 0,452 & 7200 & 0,10 & 0,0 & 1,0 & 55 & 071 & 0 & 4 & 2,000 & 226,000 & 240 \\
\hline 0,500 & 7800 & 0,10 & & 1,0 & \begin{tabular}{|l|}
0,07065 \\
\end{tabular} & 0,000058275 & & & 2,167 & 230,769 & 0,0480 \\
\hline & 8400 & 0,10 & & 1,0 & & 0,000058874 & & & 2,333 & 233,143 & \\
\hline & 9000 & 0,10 & & 1,0 & & & & & & 00 & \\
\hline 0,630 & 9600 & 0,10 & 0,0 & 1,0 & 0,07065 & 0,000059659 & 160 & 630 & 2,667 & 236,250 & 400 \\
\hline 0,680 & 10200 & 0,10 & 0471 & 1,0 & 0,07065 & 0,000060606 & 170 & 680 & 2,833 & 240,000 & 0,0500 \\
\hline 0,723 & 10800 & 0,10 & 00473 & 1,0 & 0,07065 & 0,000060859 & 180 & 723 & 3,000 & 241,000 & \\
\hline & 11400 & 0,10 & & 1,0 & & 0061244 & 190 & 768 & & 242,526 & \\
\hline 0,813 & 12000 & 0,10 & 0,00000479 & 1,0 & \begin{tabular}{|l|}
0,07065 \\
\end{tabular} & 0,000061591 & 200 & 813 & 3,333 & 243,900 & 0,0450 \\
\hline 0,858 & 12600 & 0,10 & 0,00000481 & 1,0 & 0,07065 & 0,000061905 & 210 & 858 & 3,500 & 245,143 & 0,0450 \\
\hline
\end{tabular}

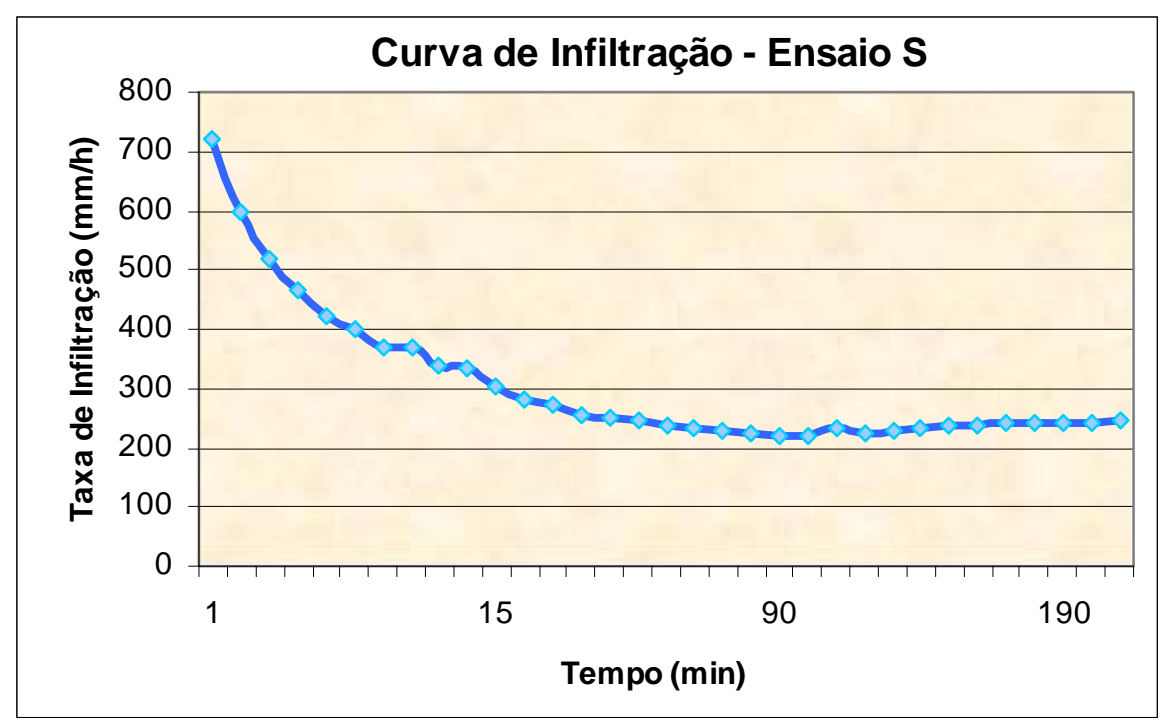




\section{Ensaio de Infiltração - IAD - Ensaio T (solo)}

\begin{tabular}{|c|c|c|c|c|c|c|c|c|c|c|c|}
\hline $\begin{array}{c}\Delta \mathbf{H} \\
(\mathbf{m})\end{array}$ & $\begin{array}{c}\mathrm{t} \\
(\mathrm{seg})\end{array}$ & $\underset{(\mathbf{m})}{H}$ & $\begin{array}{c}Q \\
\left(\mathrm{~m}^{3} / \mathrm{s}\right)\end{array}$ & $\begin{array}{l}\text { Zw } \\
(m)\end{array}$ & $\underset{(\mathrm{m} 2)}{\mathrm{A}}$ & $\begin{array}{c}\mathrm{K} \\
(\mathrm{m} / \mathrm{s})\end{array}$ & $\begin{array}{c}\mathbf{t} \\
(\mathrm{min})\end{array}$ & $\begin{array}{c}\mathrm{DH} \\
(\mathrm{mm})\end{array}$ & $\begin{array}{l}t \\
\text { (h) }\end{array}$ & $\begin{array}{c}\text { Taxa I } \\
(\mathrm{mm} / \mathrm{h})\end{array}$ & $\begin{array}{l}\Delta \mathbf{h} \\
(\mathrm{m})\end{array}$ \\
\hline 0 & 0 & 13 & 0 & 60 & & 00 & 0 & 0 & 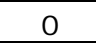 & 0 & 0 \\
\hline 0,008 & 60 & 0,13 & 00000942 & 3,60 & 0,07065 & 0,000128686 & 7 & 8 & 0,017 & \begin{tabular}{|l|l|}
480,000 \\
\end{tabular} & 0080 \\
\hline 013 & 120 & 13 & 0,00000765 & 3,60 & 0,07065 & 0,000104558 & 2 & 13 & 0,033 & \begin{tabular}{|l|}
390,000 \\
\end{tabular} & 0,0050 \\
\hline 0,019 & 180 & 0,13 & 0,00000746 & 3,60 & 0,07065 & 0,000101877 & 3 & 19 & 0,050 & 380,000 & 0,0060 \\
\hline 0,021 & 240 & 0,13 & 0,00000618 & 3,60 & 0,07065 & 0,000084450 & 4 & 21 & 0,067 & 315,000 & 0,0020 \\
\hline 0,024 & 300 & 0,13 & 0,00000565 & 3,60 & 0,07065 & 0,000077212 & 5 & 24 & 0,083 & 288,000 & 0030 \\
\hline 0,028 & 360 & 0,13 & 0,00000550 & 3,60 & 0,07065 & 0,000075067 & 6 & 28 & 0,100 & 280,000 & 0,0040 \\
\hline 27 & 420 & 0,13 & 000 & 3,60 & 0,07065 & & & & 0,117 & & \\
\hline 0,037 & 480 & 0,13 & 0,00000545 & 3,60 & 0,07065 & 0,0000 & 8 & & 0,133 & 277,500 & 0,0050 \\
\hline 0,041 & 540 & 0,13 & 0,00 & 3,60 & 0,07065 & 280 & 9 & 41 & 0,150 & 333 & 0,0040 \\
\hline 0,045 & 600 & 0,13 & 0,00 & 3,60 & 0,07065 & 0,00 & 10 & 4 & 0,167 & \begin{tabular}{|l|}
270,000 \\
\end{tabular} & 0040 \\
\hline 0067 & 900 & 0,13 & 0,0000 & 3,60 & 0,07065 & 0,00 & 15 & 67 & 0,250 & 268,000 & 0,0220 \\
\hline 089 & 1200 & 0,13 & 0,00 & 3,60 & 0,07065 & 0,00 & 20 & of & 0,333 & \begin{tabular}{|l|}
267,000 \\
\end{tabular} & 0,0220 \\
\hline 0,109 & 1500 & 0,13 & 0,00000513 & 3,60 & 0,07065 & 0,000 & 25 & 109 & 0,417 & 261,600 & 0,0200 \\
\hline 120 & 1800 & 0,13 & 0,00 & 3,60 & 0,07065 & & 30 & 12 & 0,500 & 000 & 0,0200 \\
\hline 0,148 & 2100 & 0,13 & 0,00000498 & 3,60 & 0,07065 & 0,000068020 & 35 & 14 & 0,583 & \begin{tabular}{|l|}
253,714 \\
\end{tabular} & 0,0190 \\
\hline 0,168 & 2400 & 0,13 & 0,000 & 3,60 & 0,0 & 0,00 & 40 & 1 & 0,667 & 252,000 & 0,0200 \\
\hline 208 & 3000 & 0,13 & 0,00 & 3,60 & 0,0 & 0,00 & $\Gamma$ & 2 & 0,833 & 600 & 0,0400 \\
\hline 0,244 & 3600 & 0,13 & 0,00000479 & 3,60 & 0,07065 & 0,000065416 & 60 & 244 & 1,000 & 244,000 & 0,0360 \\
\hline & 4200 & 0,13 & 0,00 & 3,60 & & & 70 & & 1,167 & 857 & 0,0440 \\
\hline 0,320 & 4800 & 0,13 & 0,00000471 & 3,60 & 0,07065 & 0,000 & 80 & 32 & 1,333 & 240,000 & 0,0320 \\
\hline 0,356 & 5400 & 0,13 & 0,00000466 & 3,60 & 0,07065 & 0,000063628 & 90 & 35 & 1,500 & 237,333 & 0,0360 \\
\hline 877 & 6000 & & 0,00000467 & 3,60 & 0 & 0000 & 70 & & 1,667 & & \\
\hline 0,433 & 6600 & 0,13 & 0,00000464 & 3,60 & 0,07065 & 0,000063320 & 110 & 433 & 1,833 & 236,182 & 0,0360 \\
\hline 0,469 & 7200 & 0,13 & 0,00000460 & 3,60 & 0,07065 & 0,000062869 & 12 & 46 & 2,000 & 234,500 & 0,0360 \\
\hline & 7800 & 0, & & 3,60 & 0,07065 & 0,000062735 & 13 & & 2,167 & 234,000 & 0,0380 \\
\hline 0,545 & 8400 & 0,13 & 0,00000458 & 3,60 & 0,07065 & 0,000062620 & 140 & 545 & 2,333 & \begin{tabular}{|l|}
233,571 \\
\end{tabular} & 0,0380 \\
\hline 583 & 9000 & 0,13 & 0,00000458 & 3,60 & 0,07065 & 0,000062520 & 150 & 583 & 2,500 & 233,200 & 0,0380 \\
\hline
\end{tabular}

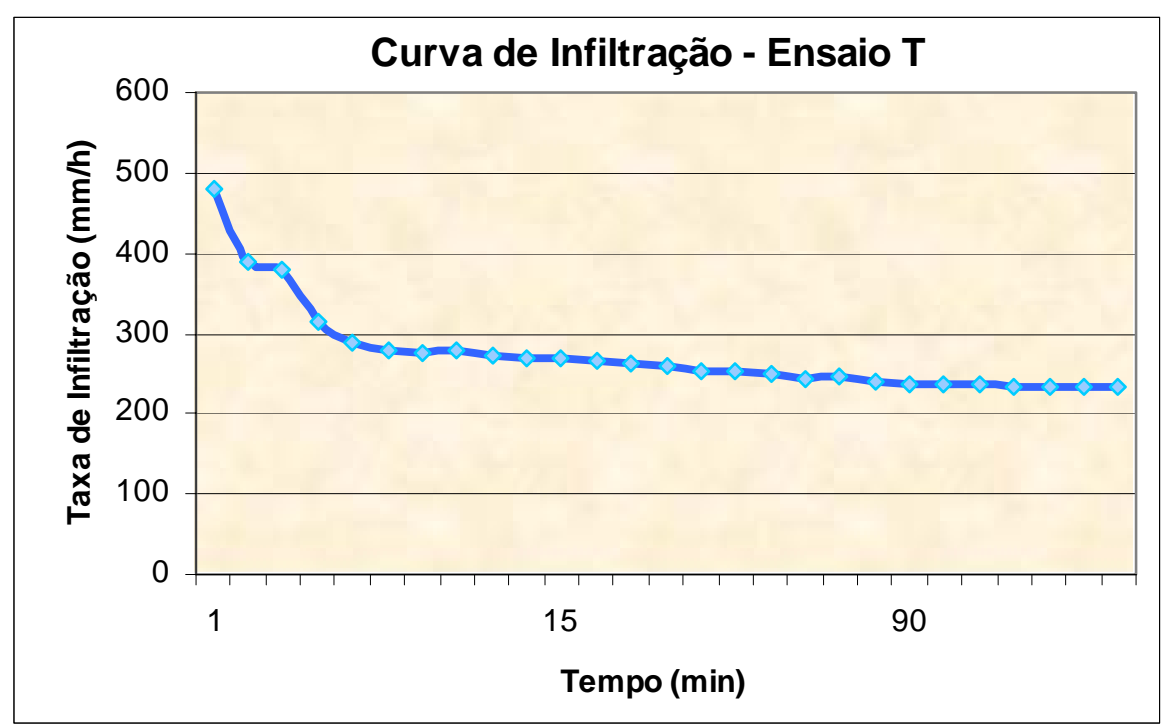




\section{Ensaio de Infiltração - IAD - Ensaio U (lixo)}

\begin{tabular}{|c|c|c|c|c|c|c|c|c|c|c|c|}
\hline $\begin{array}{l}\Delta H \\
(\mathbf{m})\end{array}$ & $\begin{array}{c}t \\
(\text { seg })\end{array}$ & $\underset{(\mathbf{m})}{\mathbf{H}}$ & $\begin{array}{c}Q \\
(m 3 / s)\end{array}$ & $\begin{array}{l}\mathrm{Zw} \\
(\mathrm{m})\end{array}$ & $\underset{(\mathrm{m} 2)}{A}$ & $\begin{array}{c}K \\
(\mathrm{~m} / \mathrm{s})\end{array}$ & $\underset{(\mathrm{min})}{\mathrm{t}}$ & $\begin{array}{c}\mathrm{DH} \\
(\mathrm{mm})\end{array}$ & $\begin{array}{c}t \\
(h)\end{array}$ & $\begin{array}{c}\text { Taxa I } \\
(\mathrm{mm} / \mathrm{h})\end{array}$ & $\begin{array}{l}\Delta h \\
(\mathbf{m})\end{array}$ \\
\hline 0 & 0 & & 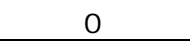 & & & & & & 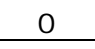 & 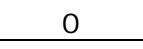 & 0 \\
\hline 008 & 60 & & 00000942 & 2 & & & & 8 & 017 & 0,000 & 0080 \\
\hline 012 & 120 & 15 & 0,00000707 & 0,2 & 0,07065 & 0,00 & 5 & 12 & 0,033 & & 040 \\
\hline 0,015 & 180 & 15 & 0,00000589 & 0,2 & 0,07065 & 0,000047619 & 3 & 15 & 0,050 & &, 0030 \\
\hline & 240 & & 0,0 & 0,2 & & & 4 & 17 & & & \\
\hline & 300 & & & 0,2 & & & 5 & & & & \\
\hline & 360 & 5 & & 0,2 & & & 6 & 21 & & & \\
\hline 22 & 420 & & & 0,2 & & & 7 & 22 & & & \\
\hline & 480 & & & 0,2 & & & 8 & 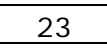 & & & \\
\hline & 540 & & & & & & 0 & & & & \\
\hline 25 & 600 & 15 & 94 & 0,2 & 65 & & 10 & 25 & 67 & & 10 \\
\hline 0,029 & & & & 0,2 & & & $1:$ & & & & \\
\hline & 1200 & & & 0,2 & & & 2 & 33 & & & \\
\hline & 1500 & & & 0,2 & & & 2 & & & & \\
\hline 0 & 1800 & 0 & 0 , & 0,2 & 55 & & 3 & 1 & 0 & & \\
\hline 0,043 & 2100 & & 0,00000145 & 0,2 & & & 35 & 43 & 0,583 & & 0,0030 \\
\hline 0,046 & 2400 & & & 0,2 & & & 40 & & & & \\
\hline & & & & 0,2 & & & 5 & & & & \\
\hline 0,058 & 3600 & 0,15 & 0,0 & 0,2 & 0,0 & 0,0 & 60 & $5 \varepsilon$ & 00 & & 50 \\
\hline 0,063 & 4200 & 0,15 & 0,00000106 & 0,2 & 0,07065 & 0,00 & 70 & 63 & 1,167 & 00 & 0,0050 \\
\hline 0,068 & 4800 & 0,15 & 0,00000100 & 0,2 & 0,07065 & 0,000008095 & 80 & 68 & 1,333 & 51,000 & \\
\hline 0,073 & 5400 & 0,15 & 0,00000096 & 0,2 & 0,07065 & 0,000007725 & 90 & 73 & 1,500 & 48,667 & 0,0050 \\
\hline
\end{tabular}

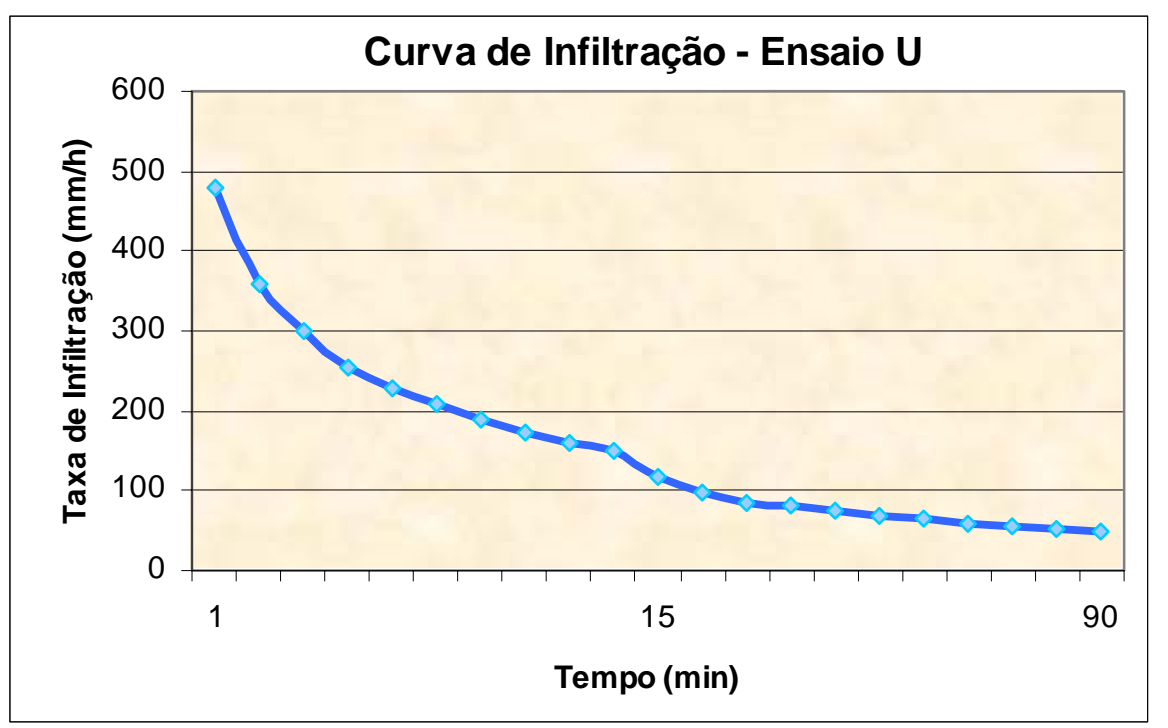




\section{Ensaio de Infiltração - IAD - Ensaio V (lixo)}

\begin{tabular}{|c|c|c|c|c|c|c|c|c|c|c|c|}
\hline $\begin{array}{l}\Delta H \\
(\mathbf{m})\end{array}$ & $\begin{array}{c}t \\
(\text { seg })\end{array}$ & $\begin{array}{c}\mathbf{H} \\
(\mathrm{m})\end{array}$ & $\begin{array}{c}Q \\
(m 3 / s)\end{array}$ & $\begin{array}{l}\mathrm{Zw} \\
(\mathrm{m})\end{array}$ & $\underset{(\mathrm{m} 2)}{\mathrm{A}}$ & $\begin{array}{c}K \\
(\mathrm{~m} / \mathrm{s})\end{array}$ & $\underset{(\mathrm{min})}{\mathrm{t}}$ & $\begin{array}{c}\mathrm{DH} \\
(\mathrm{mm})\end{array}$ & $\begin{array}{c}t \\
(h)\end{array}$ & $\begin{array}{c}\text { Taxa I } \\
(\mathrm{mm} / \mathrm{h})\end{array}$ & $\begin{array}{c}\Delta h \\
(\mathbf{m})\end{array}$ \\
\hline 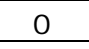 & 0 & & 0 & & & & 0 & & 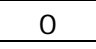 & 0 & 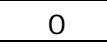 \\
\hline 0,008 & 60 & 2 & 00000 & & & & 1 & 8 & & 0,000 & \\
\hline 0,011 & 120 & 0,2 & & 15 & & & 2 & 11 & 0,033 & & 0,0030 \\
\hline 0,015 & 180 & 2 & 0,00000 & 15 & 0,07065 & & 7 & & 050 & & \\
\hline & 240 & & & 15 & & & - & & & & \\
\hline & 300 & 0,2 & & & & & $\Gamma$ & & & & \\
\hline & 360 & 0,2 & & 15 & & & 6 & 26 & & & \\
\hline 0,028 & 420 & 02 & & 75 & & & 7 & 28 & & & \\
\hline & 480 & & & & & & 8 & 3 & & & \\
\hline & 540 & , L & & & & & 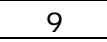 & & & & \\
\hline & 600 & 0,2 & & 5 & & & 10 & 38 & & & \\
\hline & 900 & 0,2 & & 75 & & & & 4 & & & \\
\hline 58 & 1200 & 0,2 & & - & & & 20 & & & 00 & \\
\hline & 1500 & 0,2 & & 0,15 & & & 2 & 6 & & & \\
\hline 71 & 1800 & 0,2 & 0 , & 15 & 55 & & 30 & 71 & 0 & 00 & 070 \\
\hline 0,078 & & 0,2 & & 0,15 & & & 35 & 78 & 0,583 & 714 & 0,0070 \\
\hline & 2400 & 0,2 & & & & & & 8 & & & \\
\hline$\underline{0}$ & 3000 & 0,2 & & 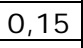 & & & & & & & \\
\hline & 3600 & 0,2 & & 0,15 & & & 60 & 111 & 00 & & 120 \\
\hline 0,122 & 4200 & 0,2 & & 0,15 & 0,07065 & 524 & 70 & 122 & 1,167 & 104,571 & 0,0110 \\
\hline & 4800 & 0,2 & & 0,15 & 0,0 & & 80 & 133 & 1,333 & & \\
\hline 0,144 & 5400 & 0,2 & 0,00000188 & 0,15 & 0,07065 & 0,000013333 & 90 & 144 & 1,500 & 96,000 & 0,0110 \\
\hline
\end{tabular}

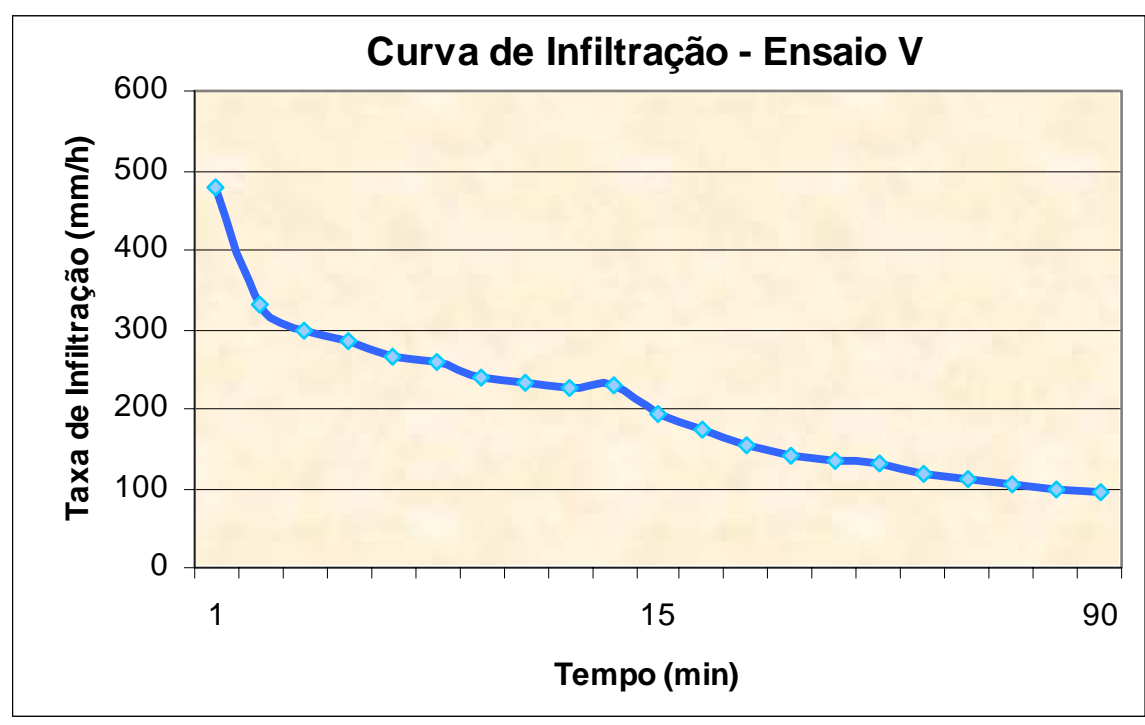




\section{Anexo V}

\section{Curvas Granulométricas Ensaio de Granulometria Conjunta}




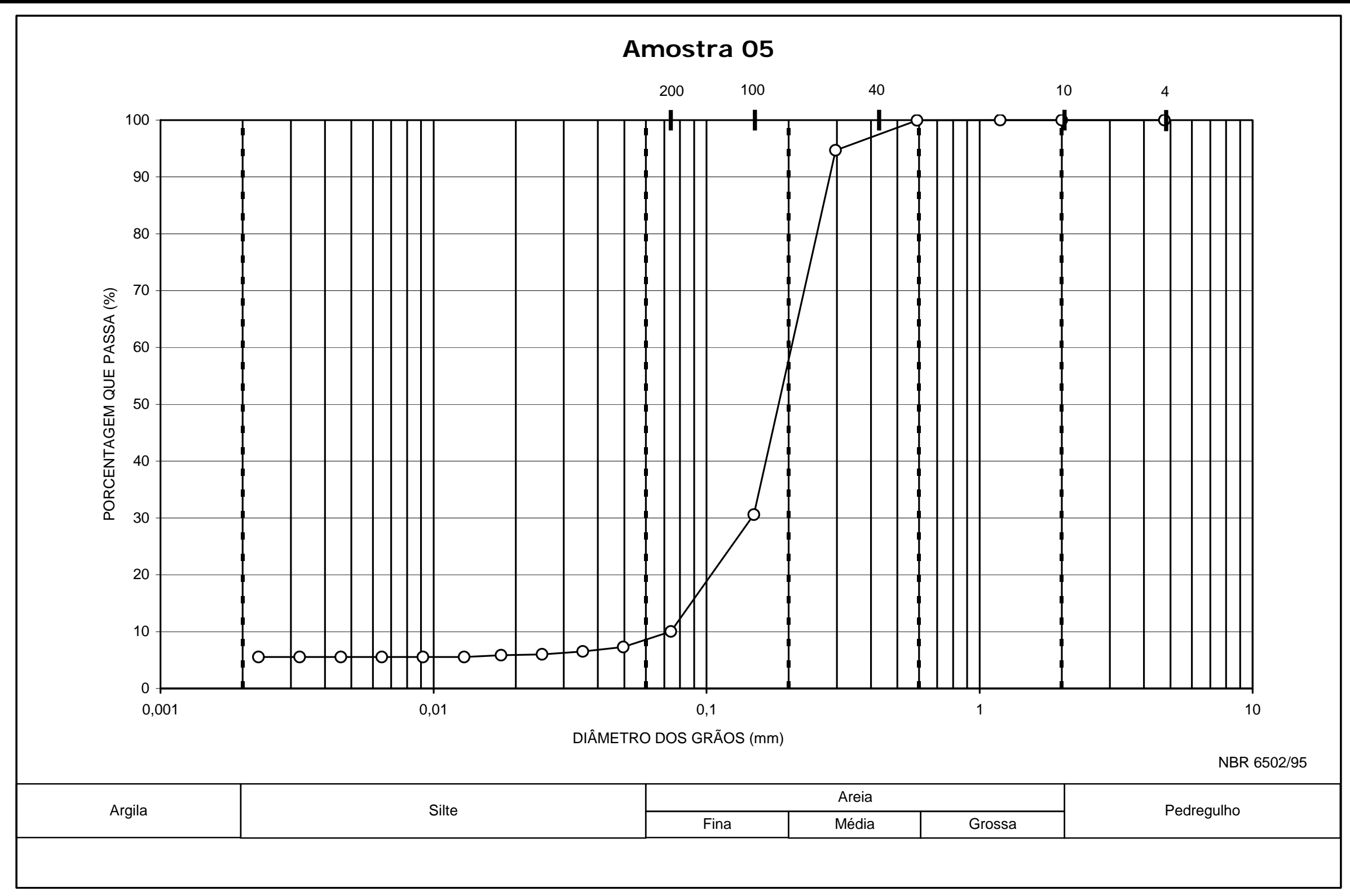




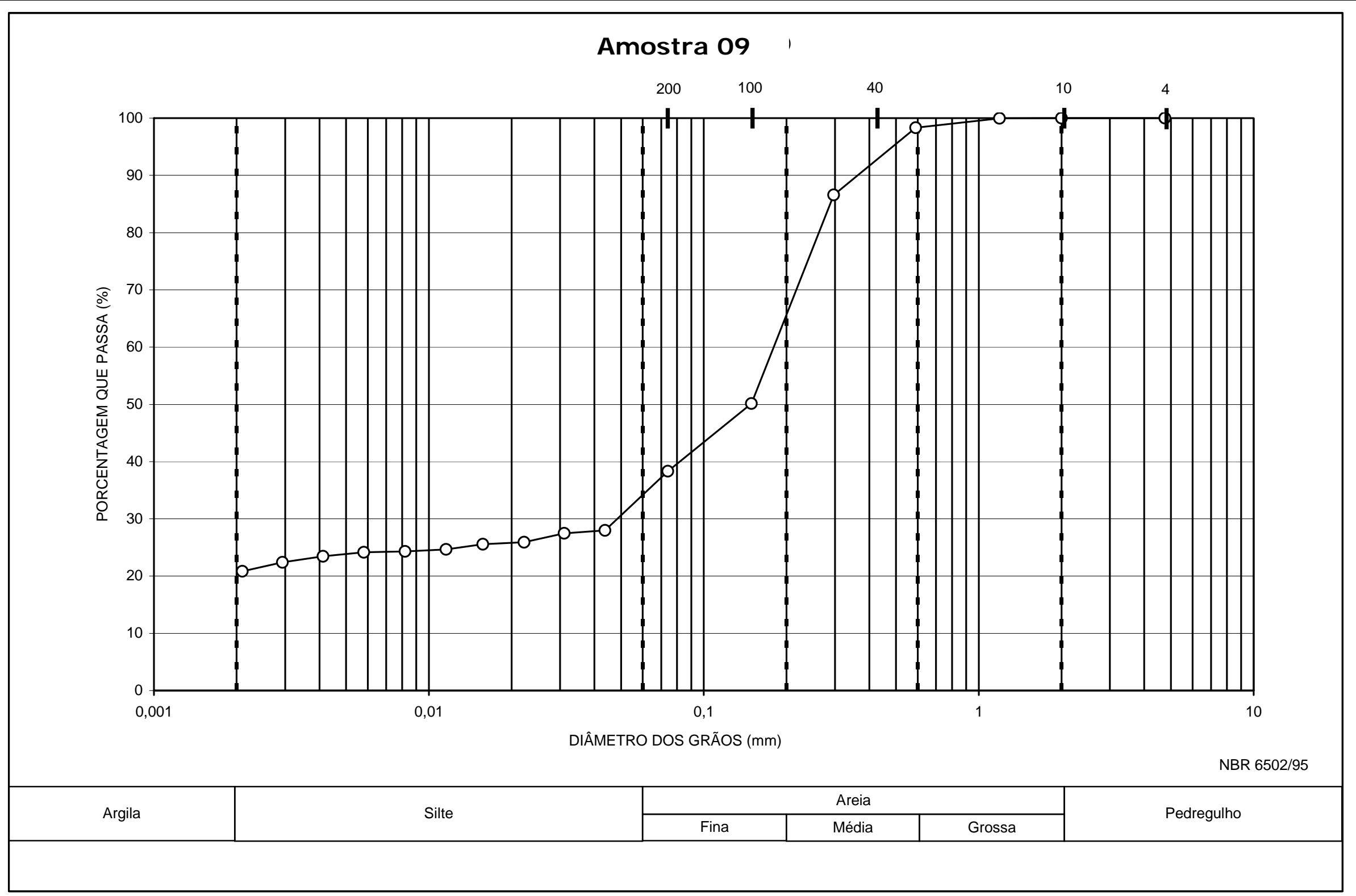




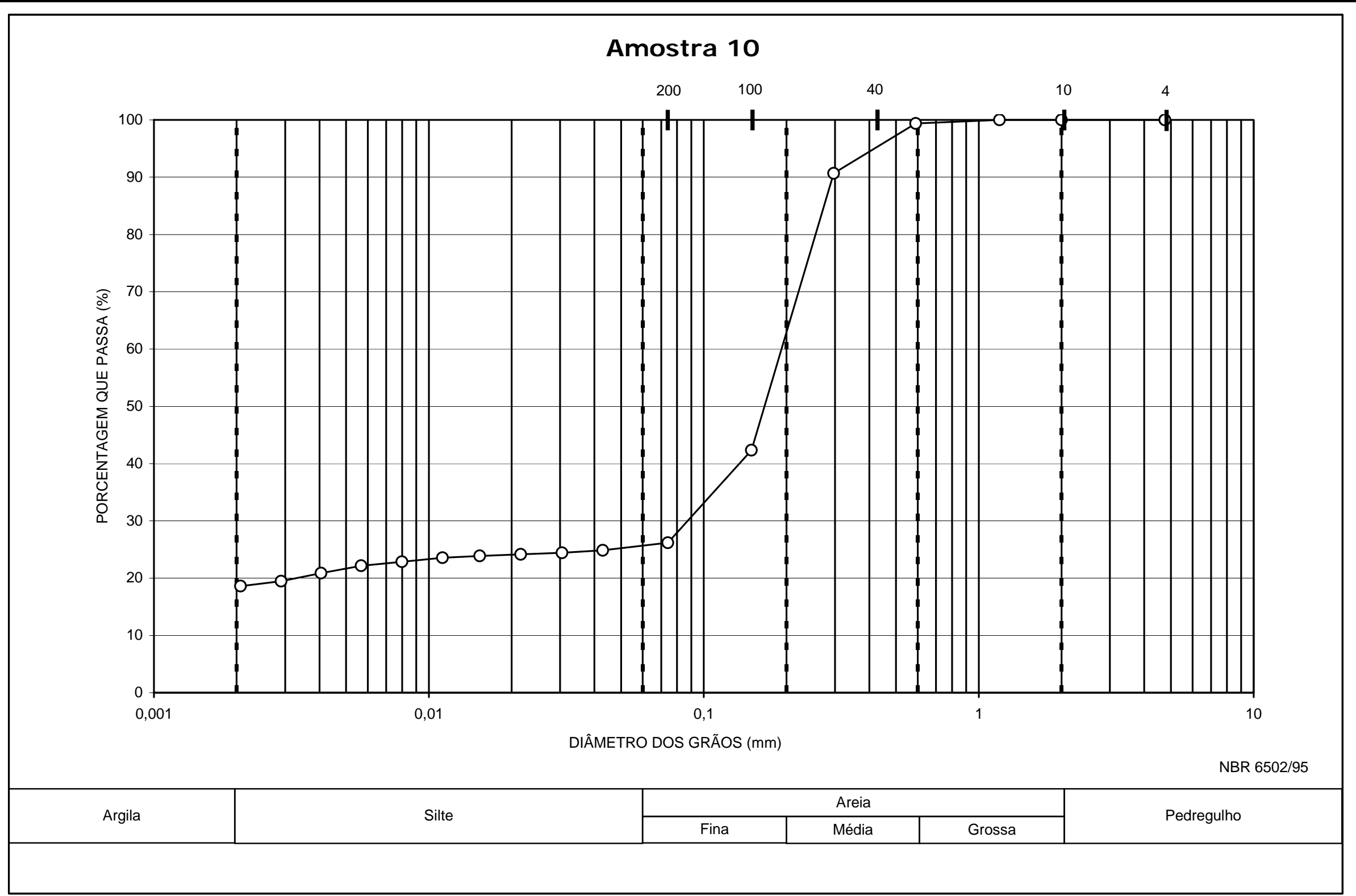




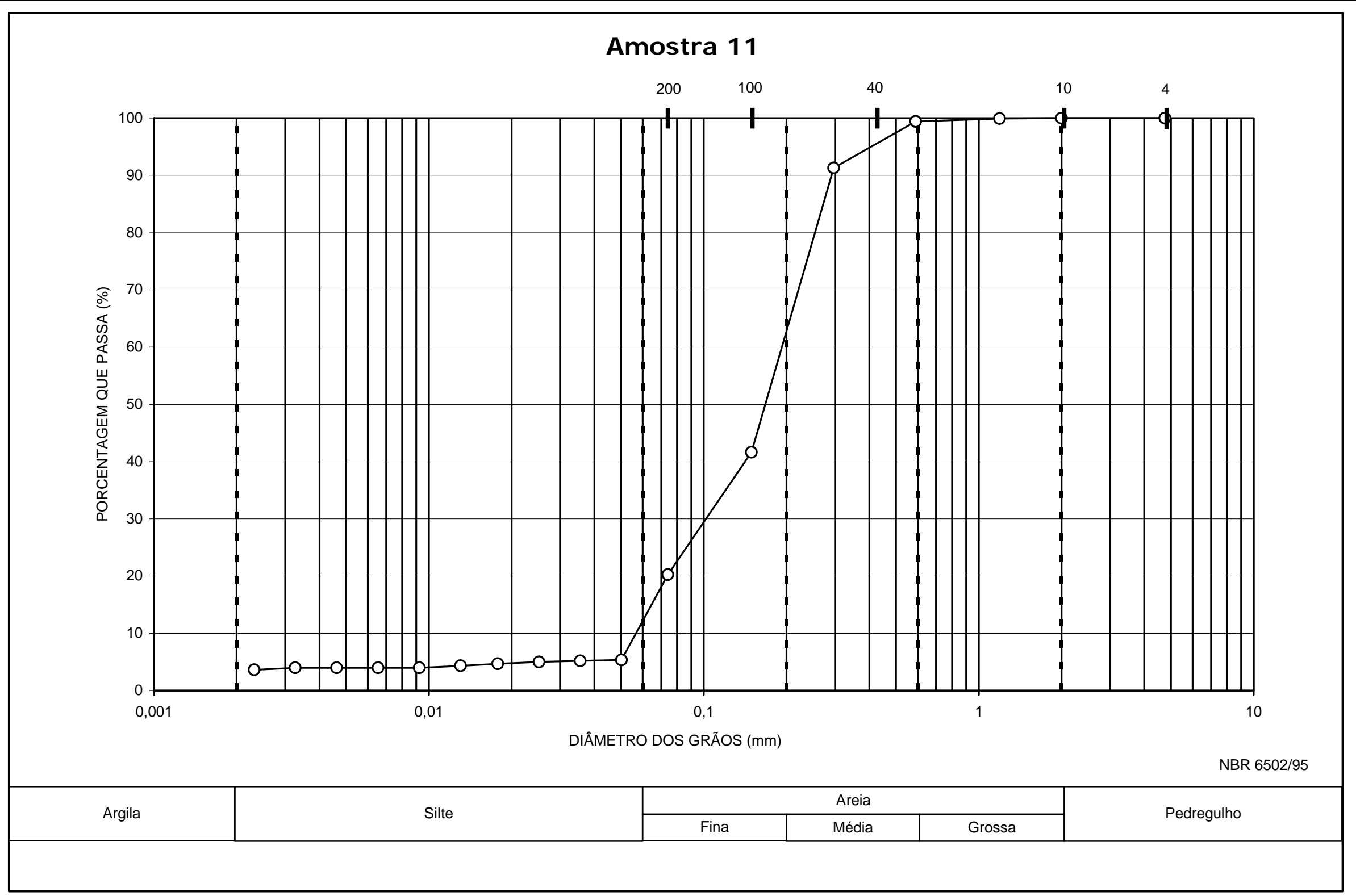




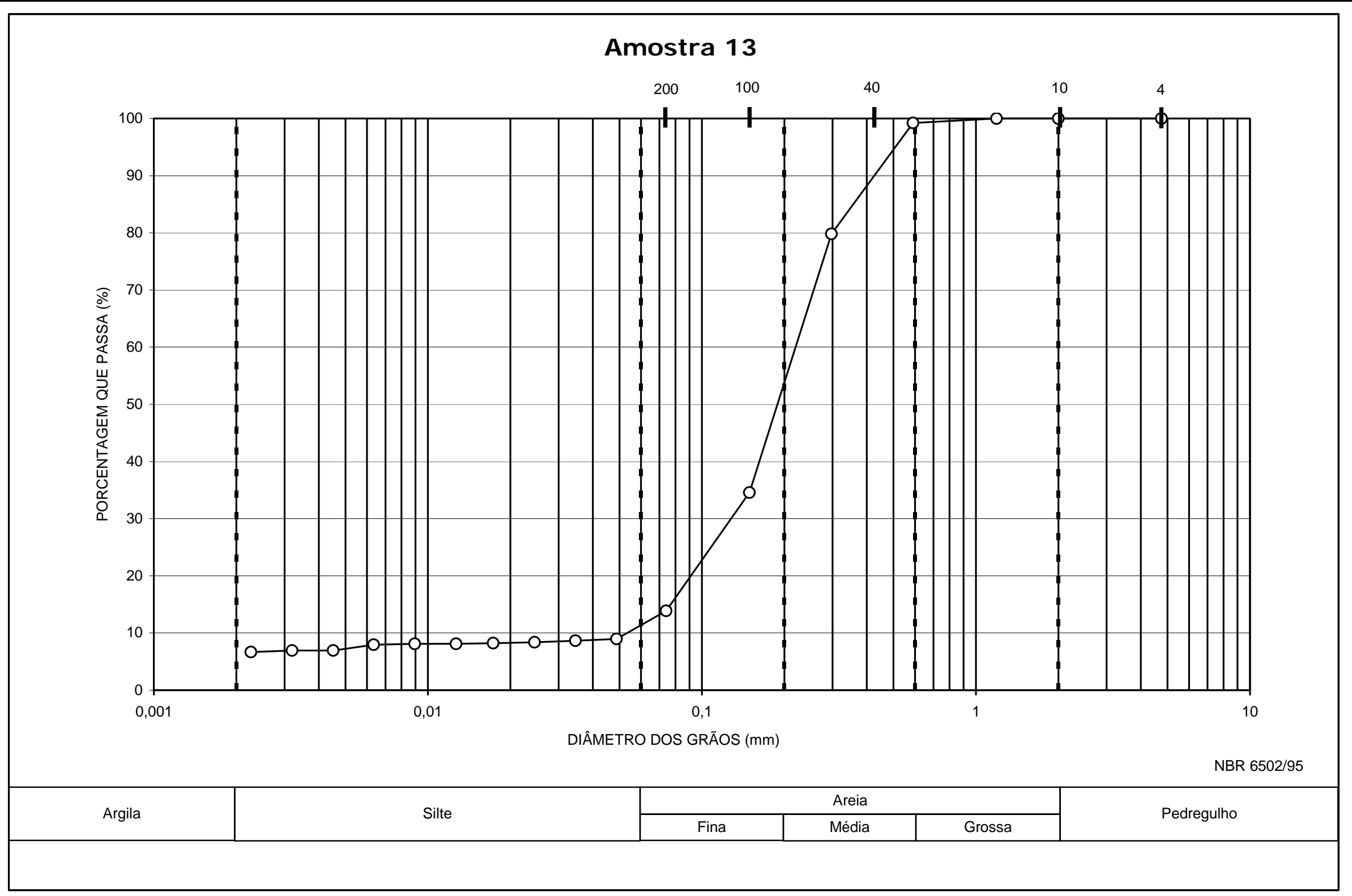




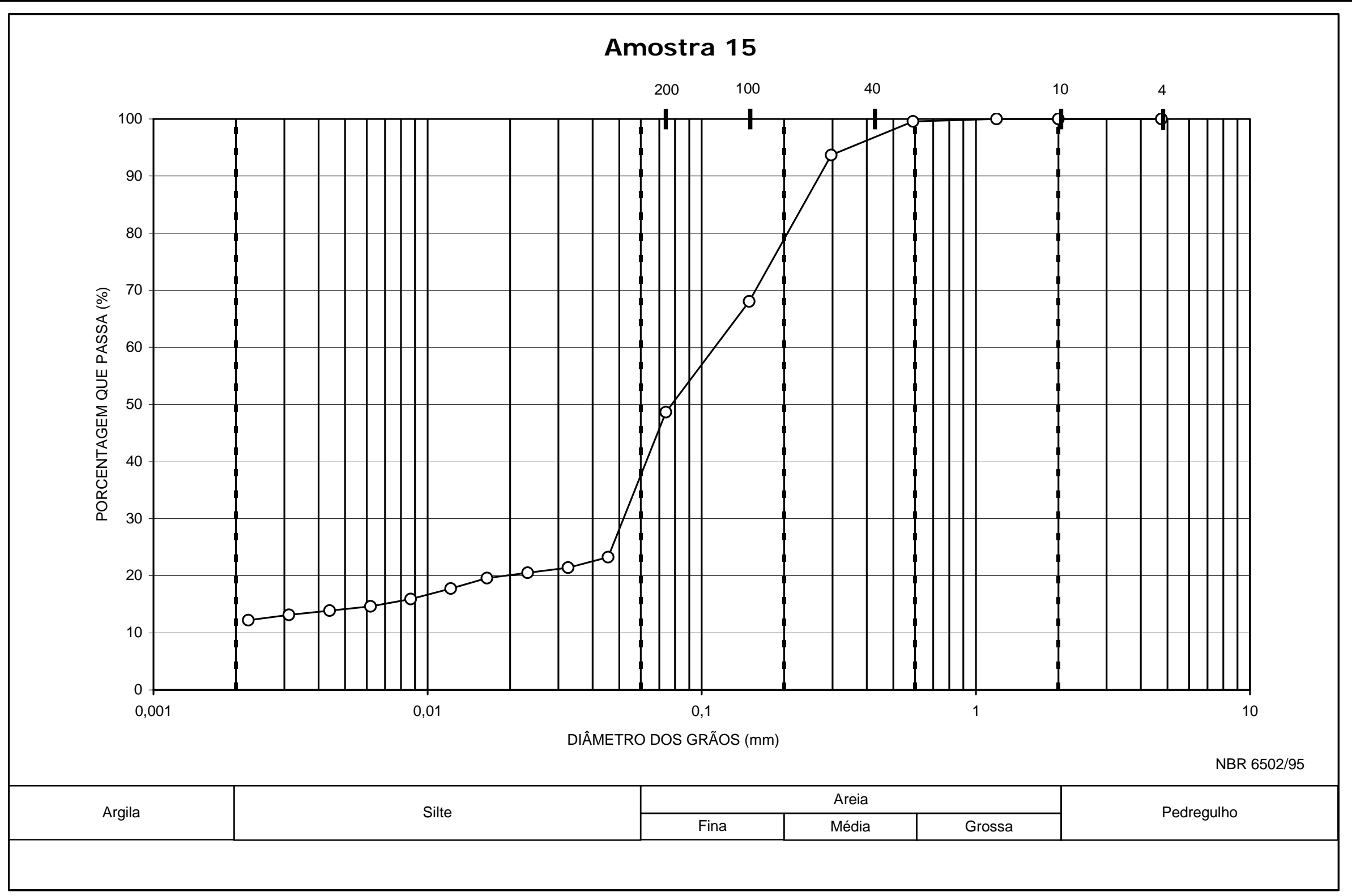




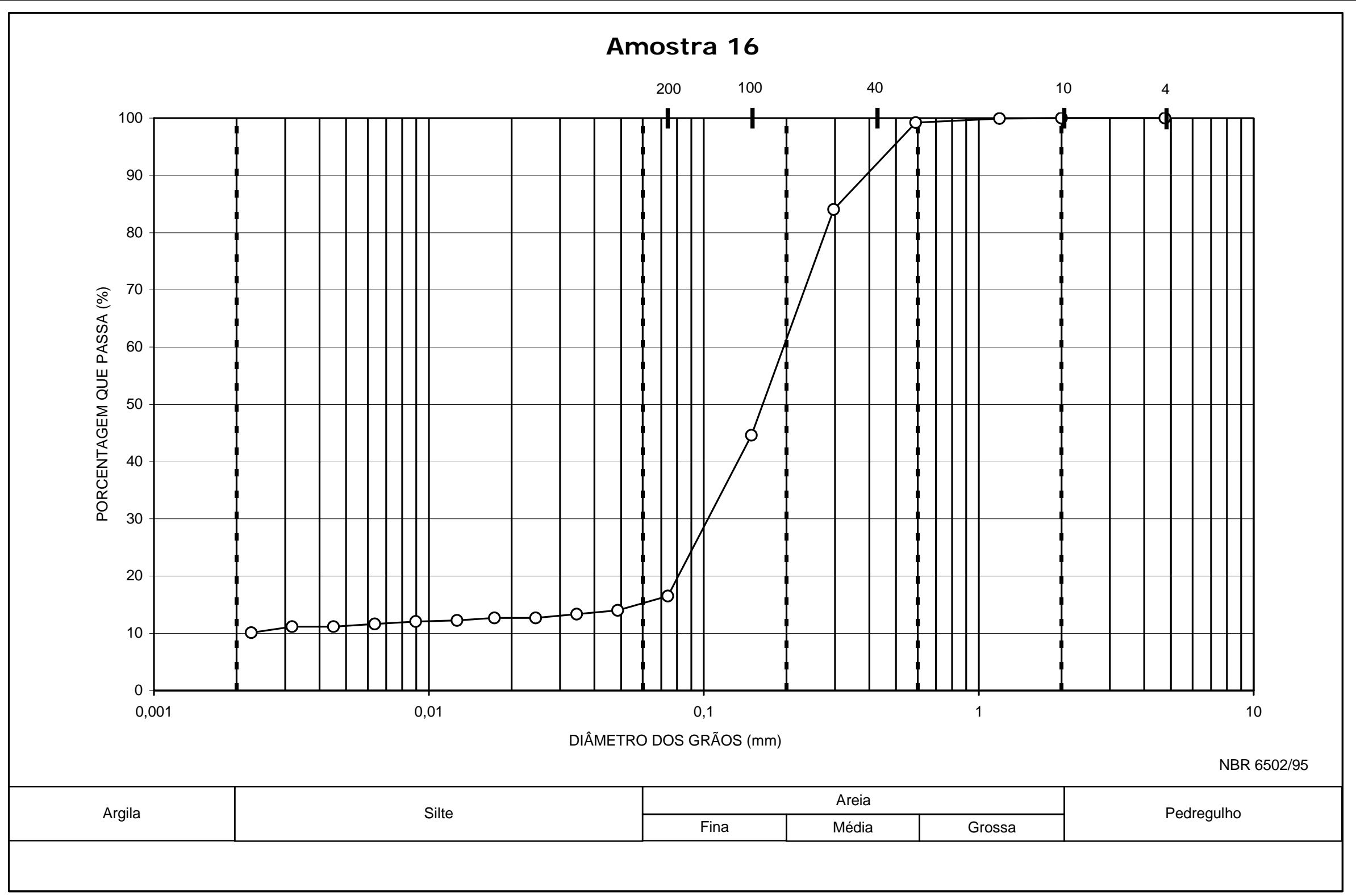




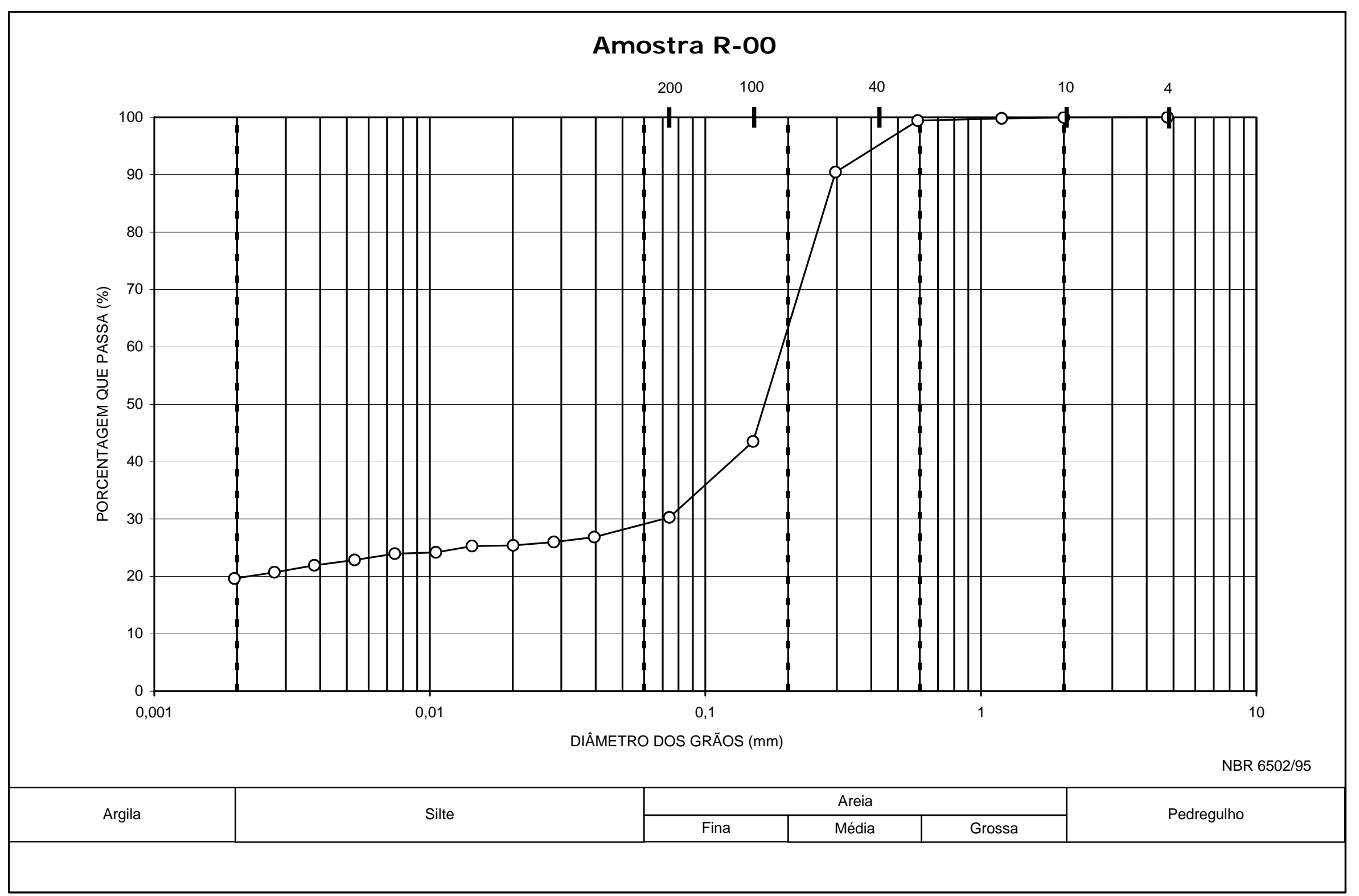




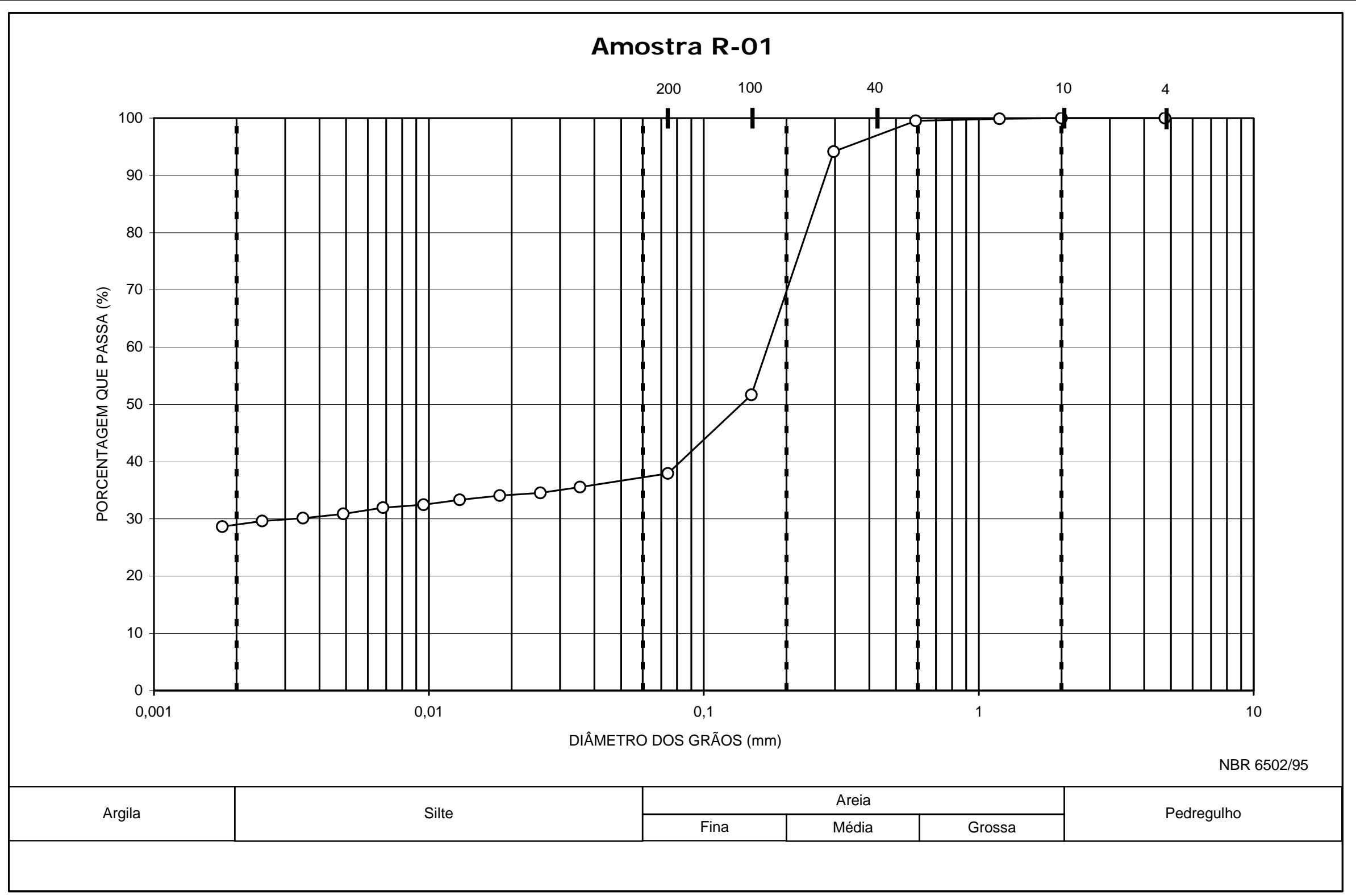




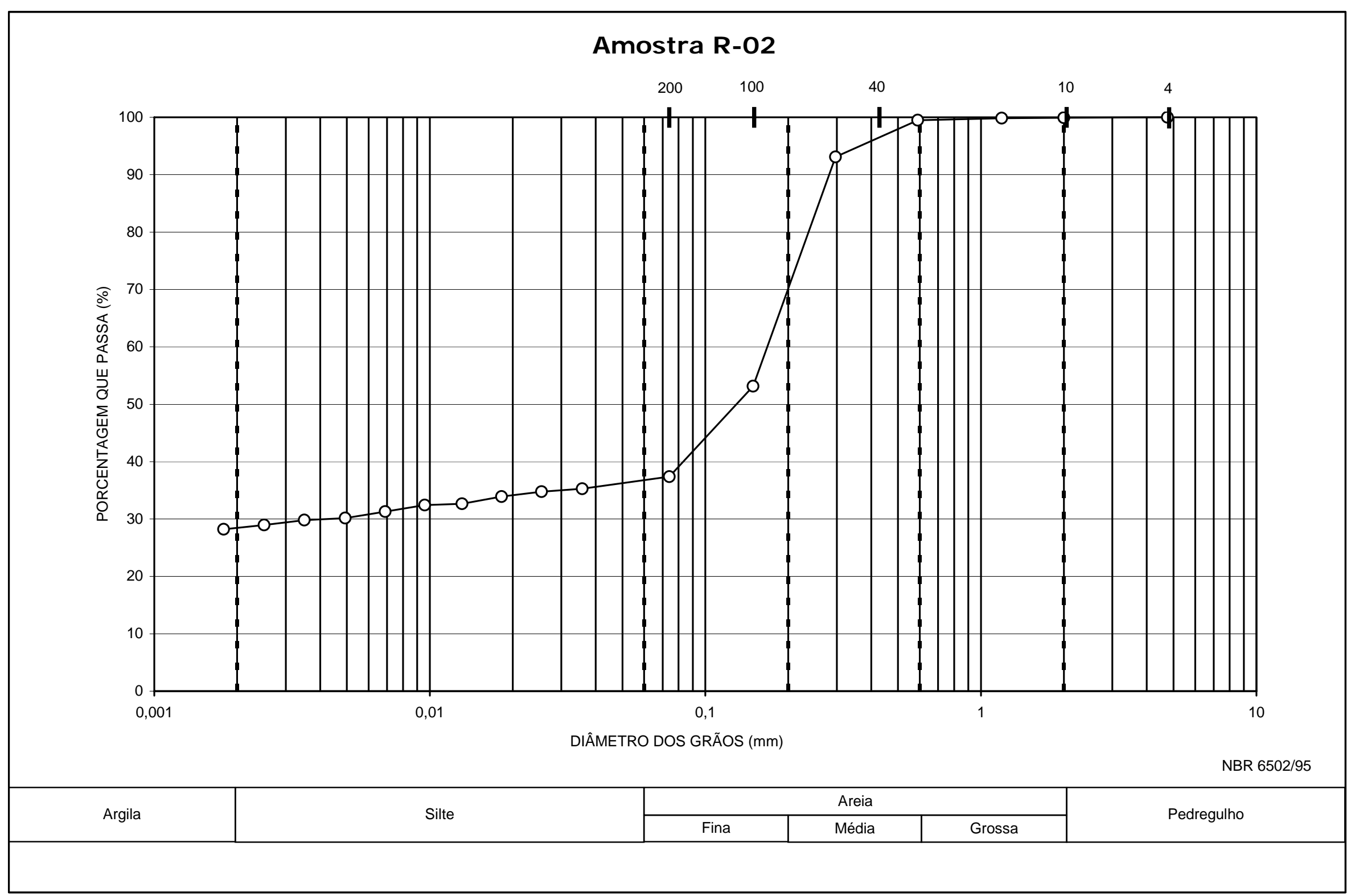




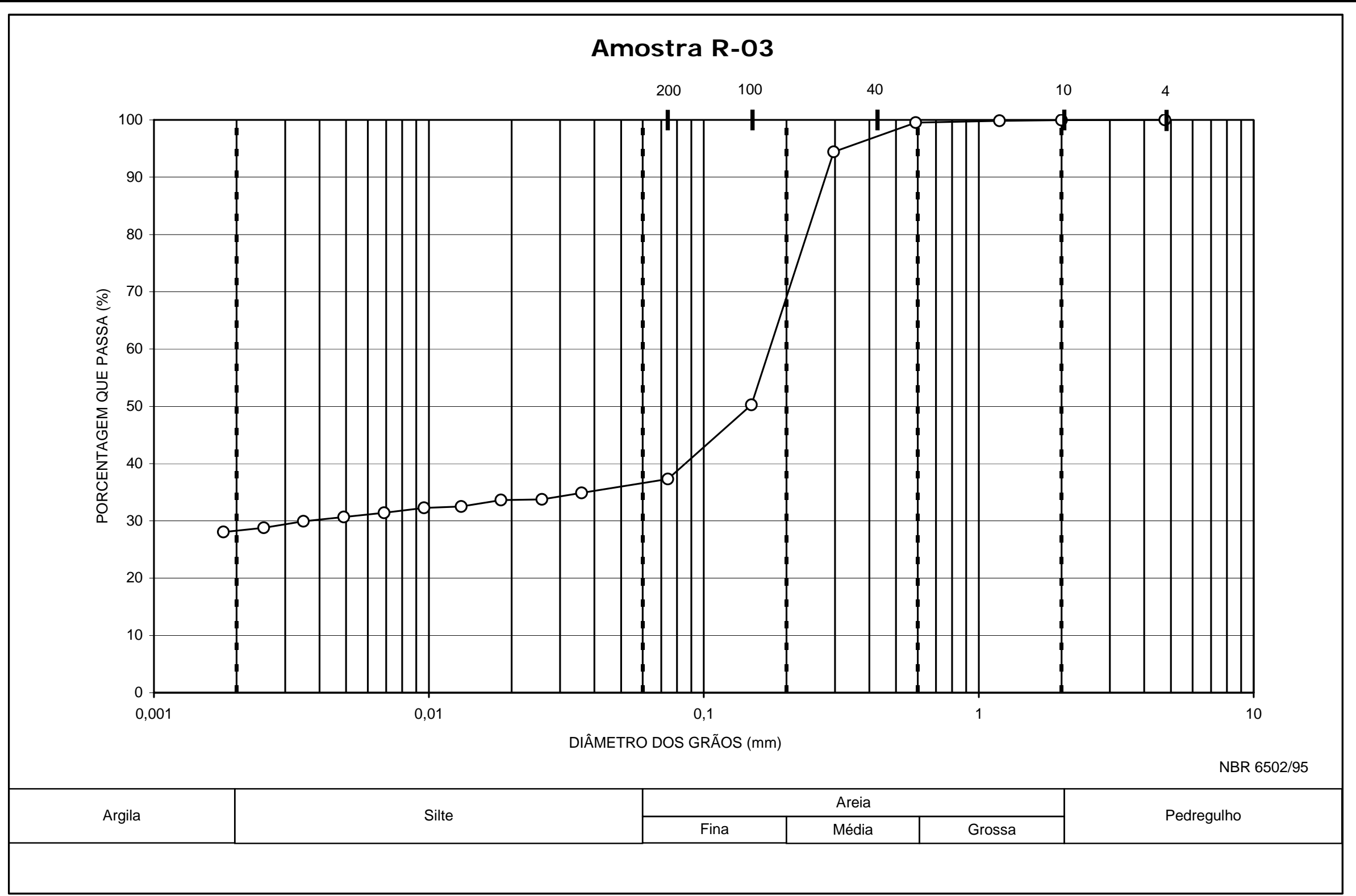




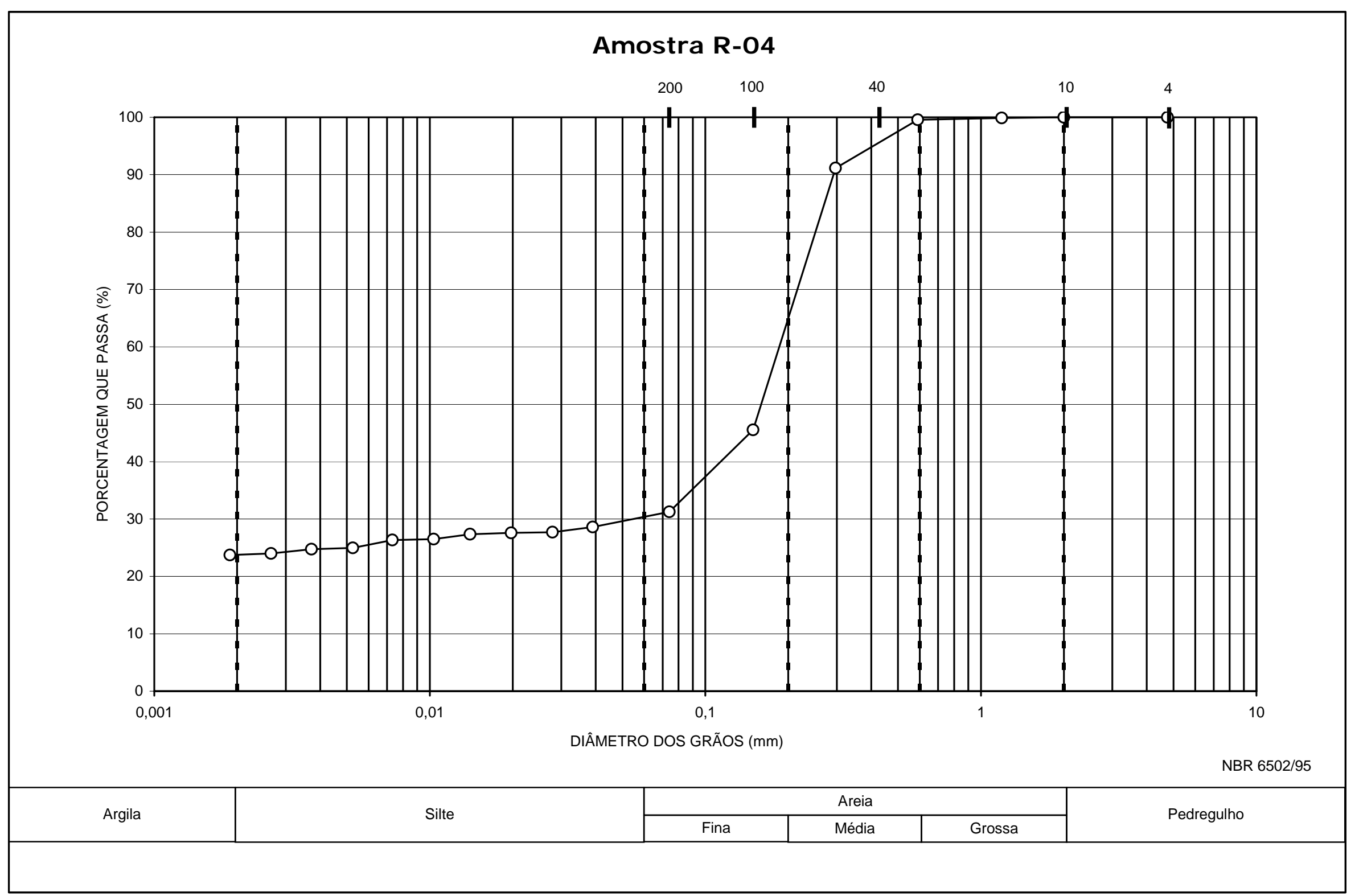




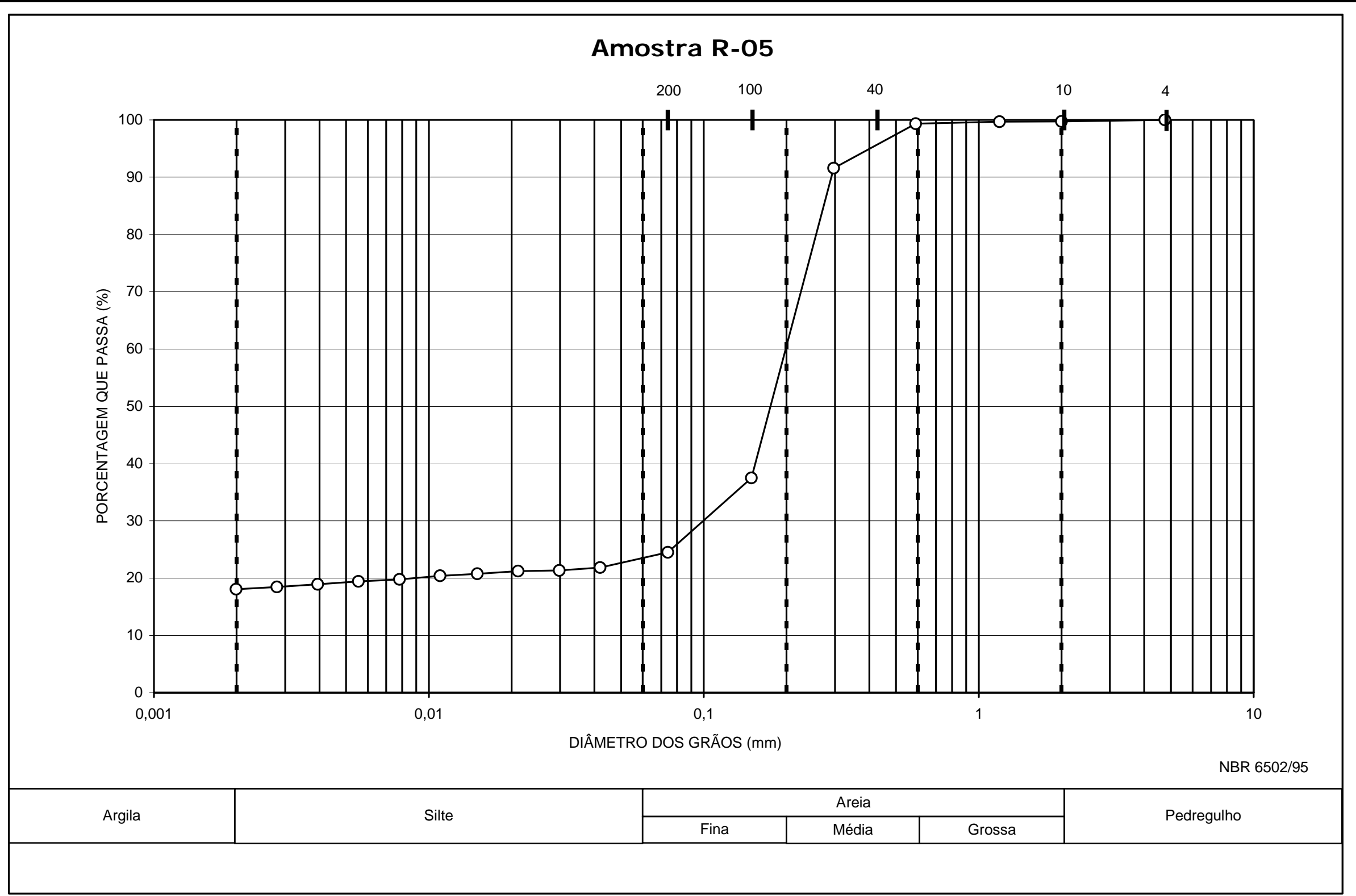




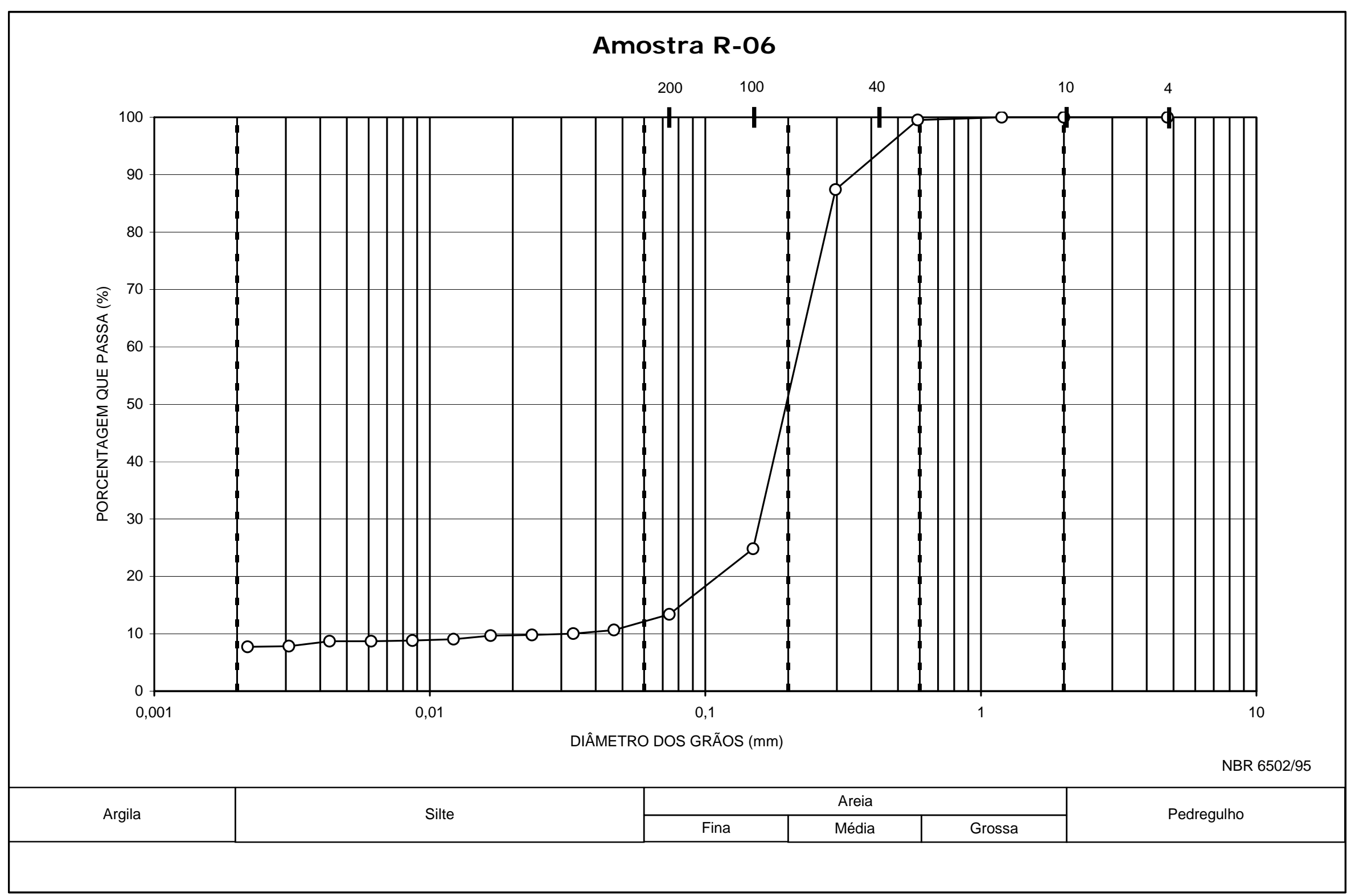




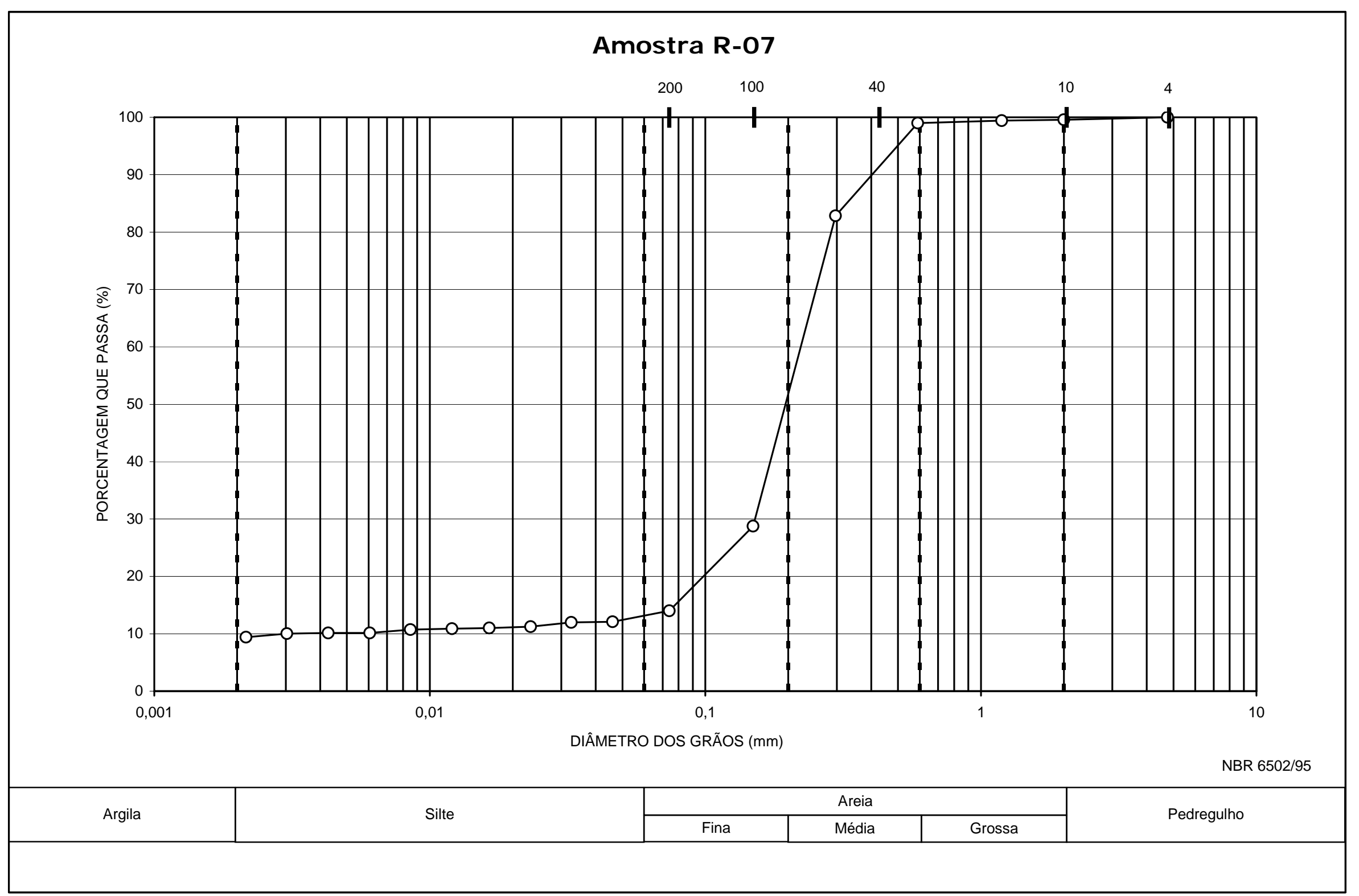




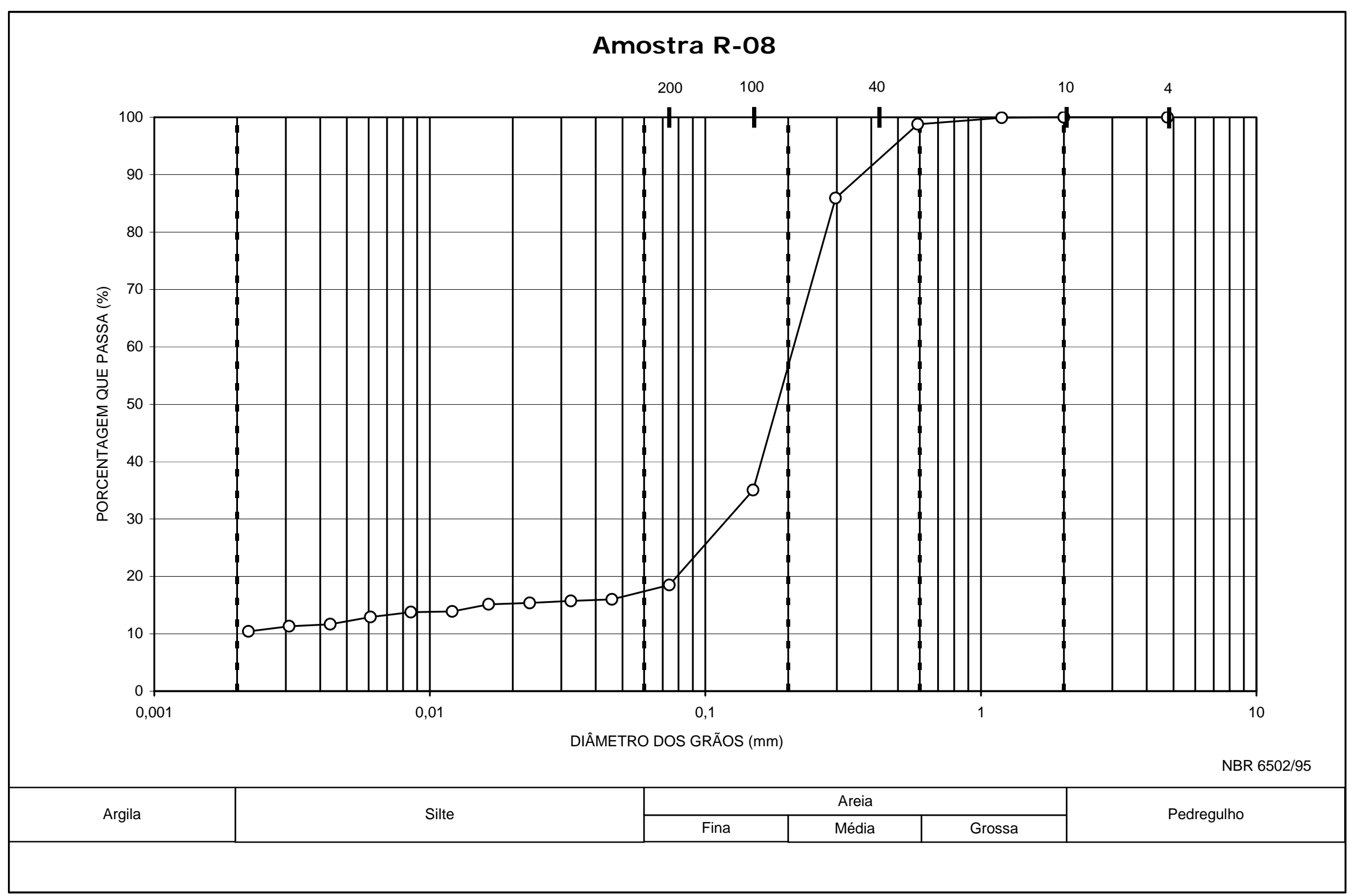




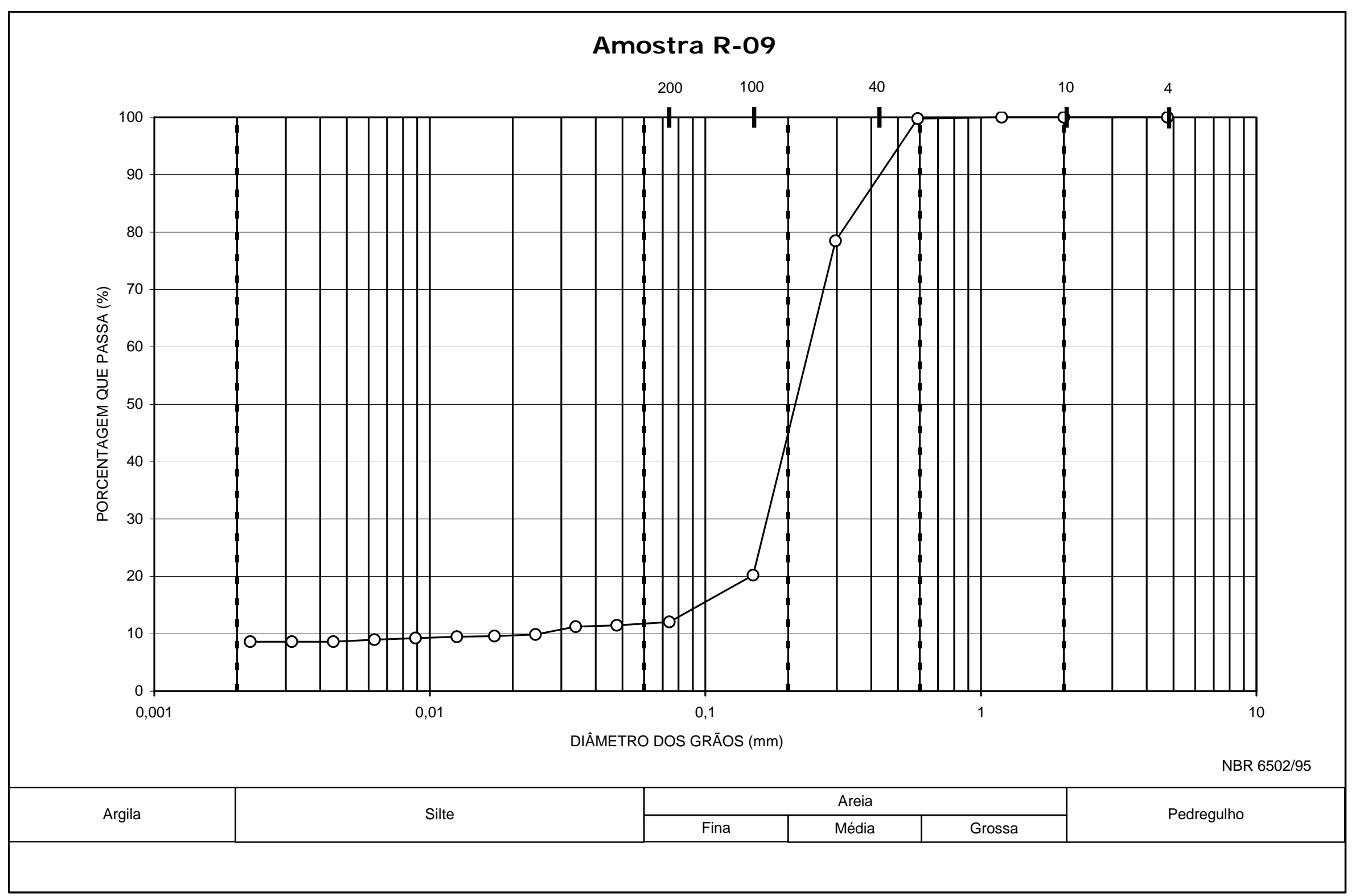




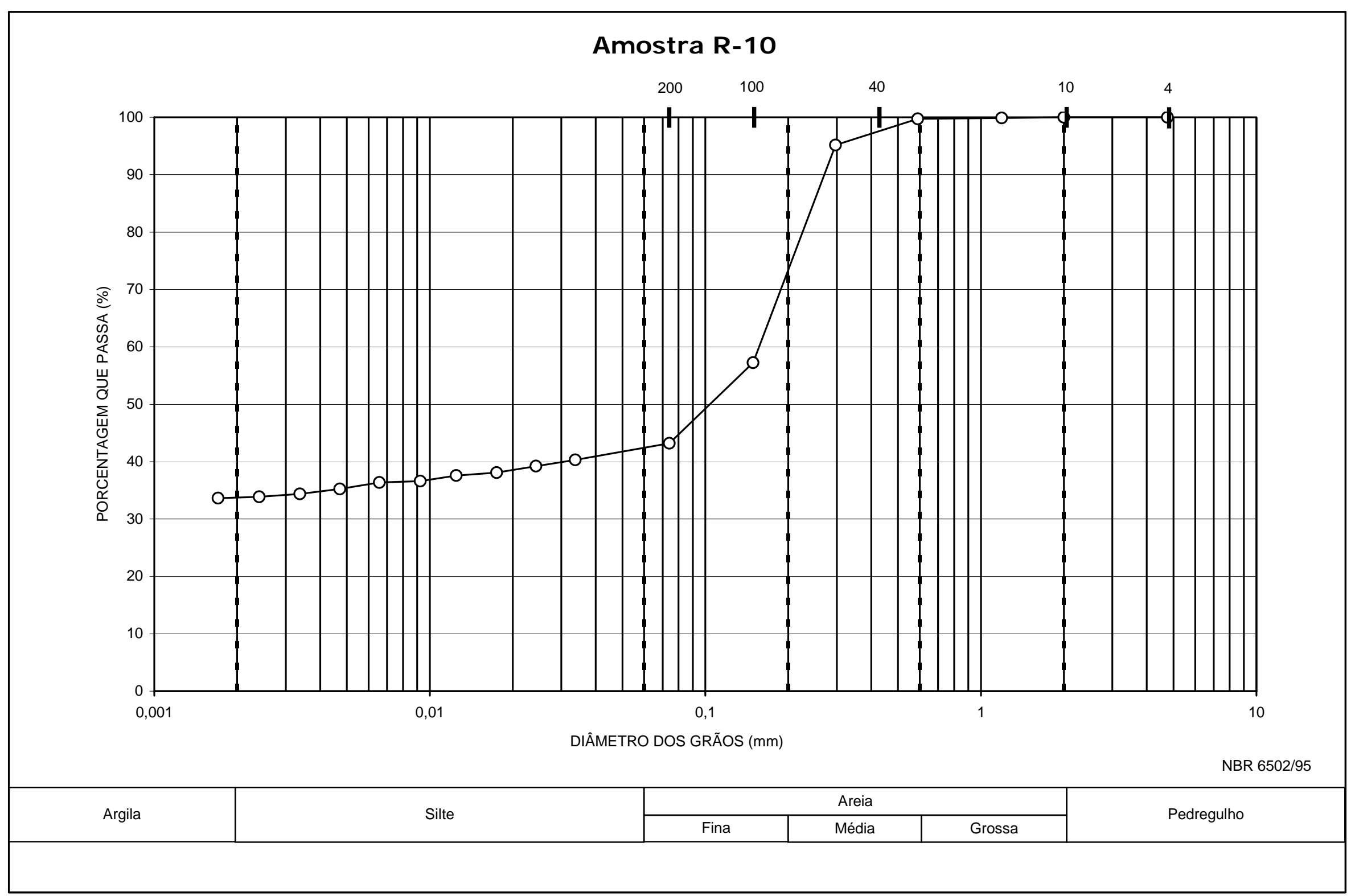




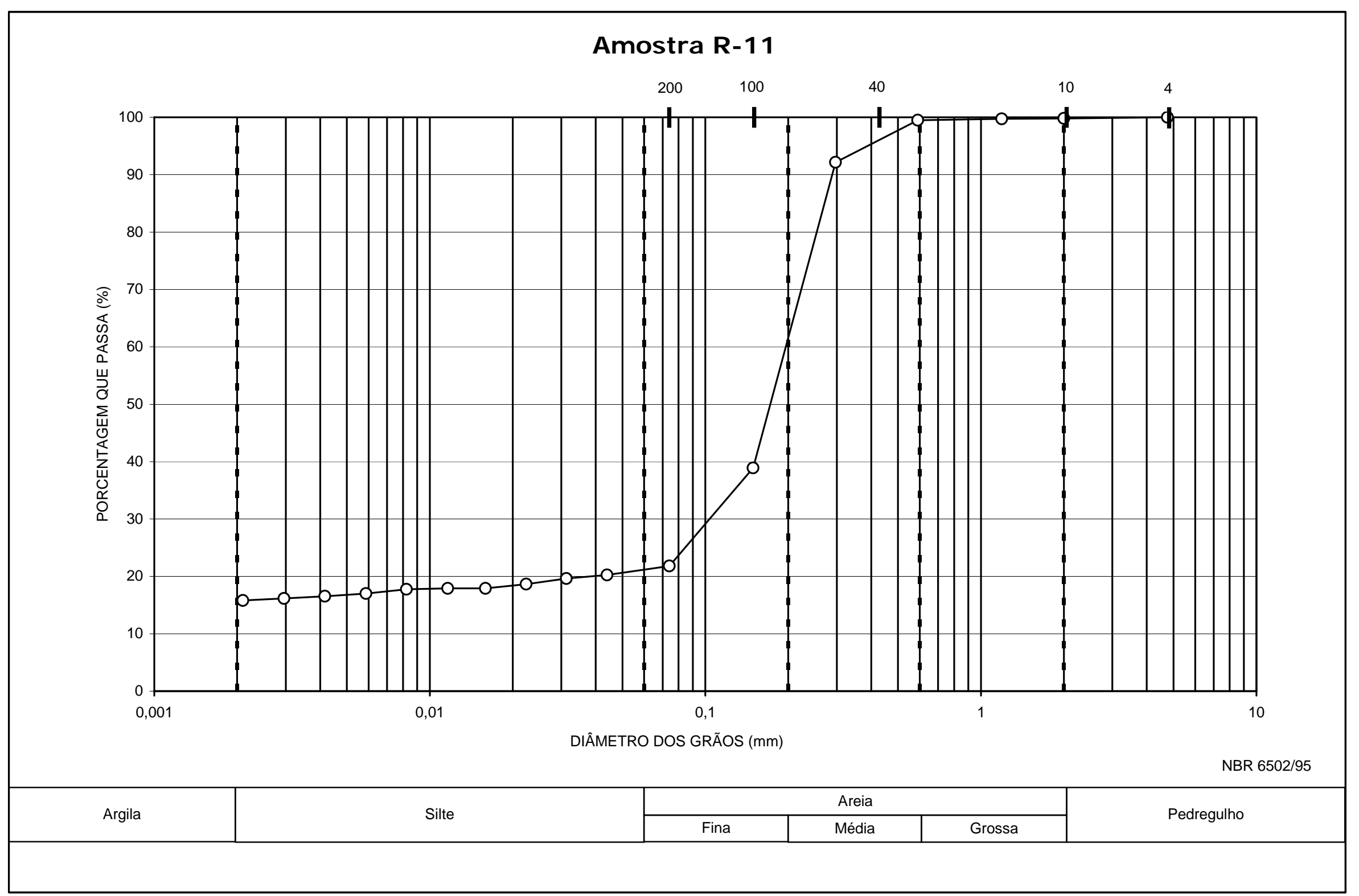




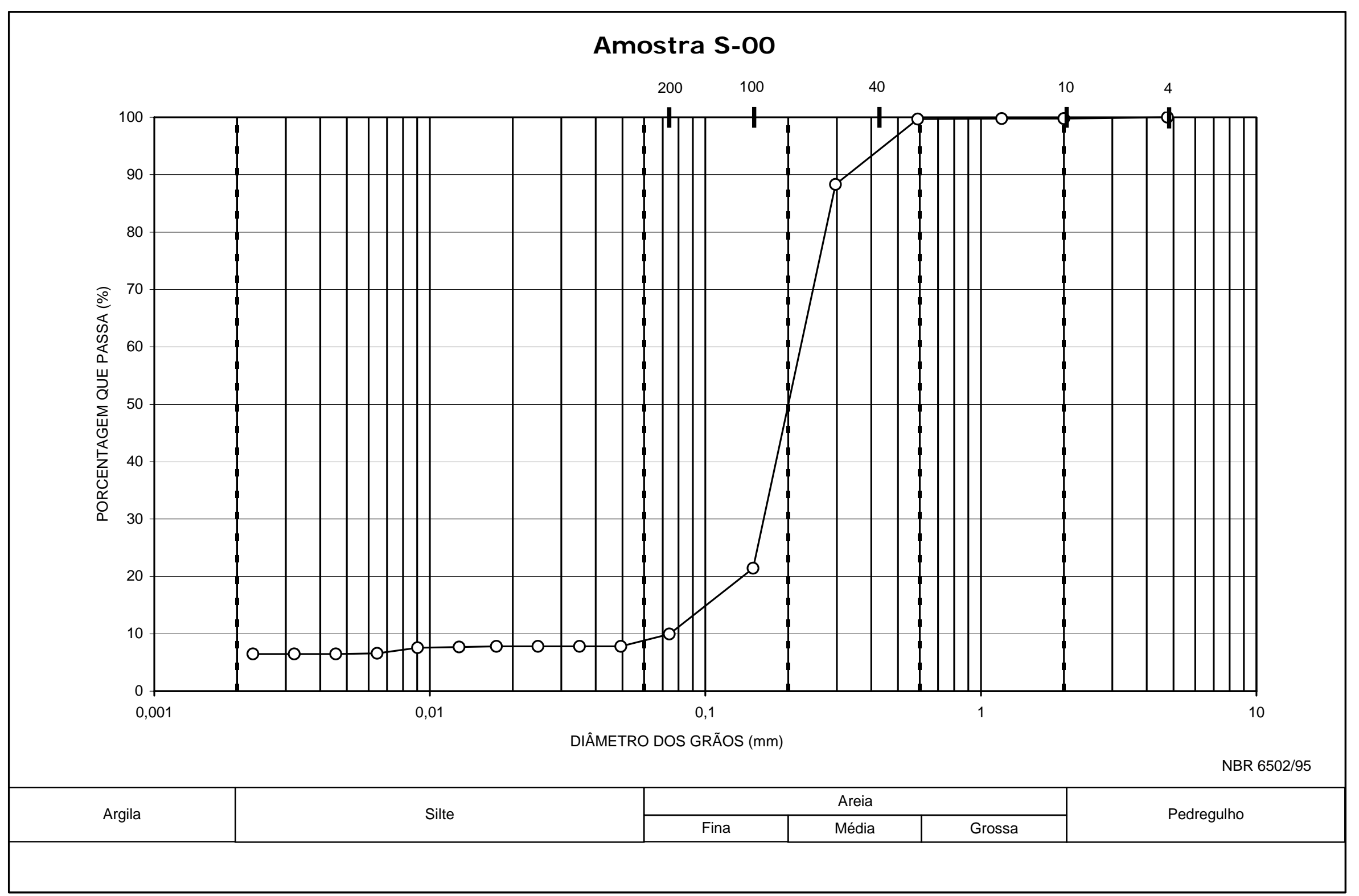




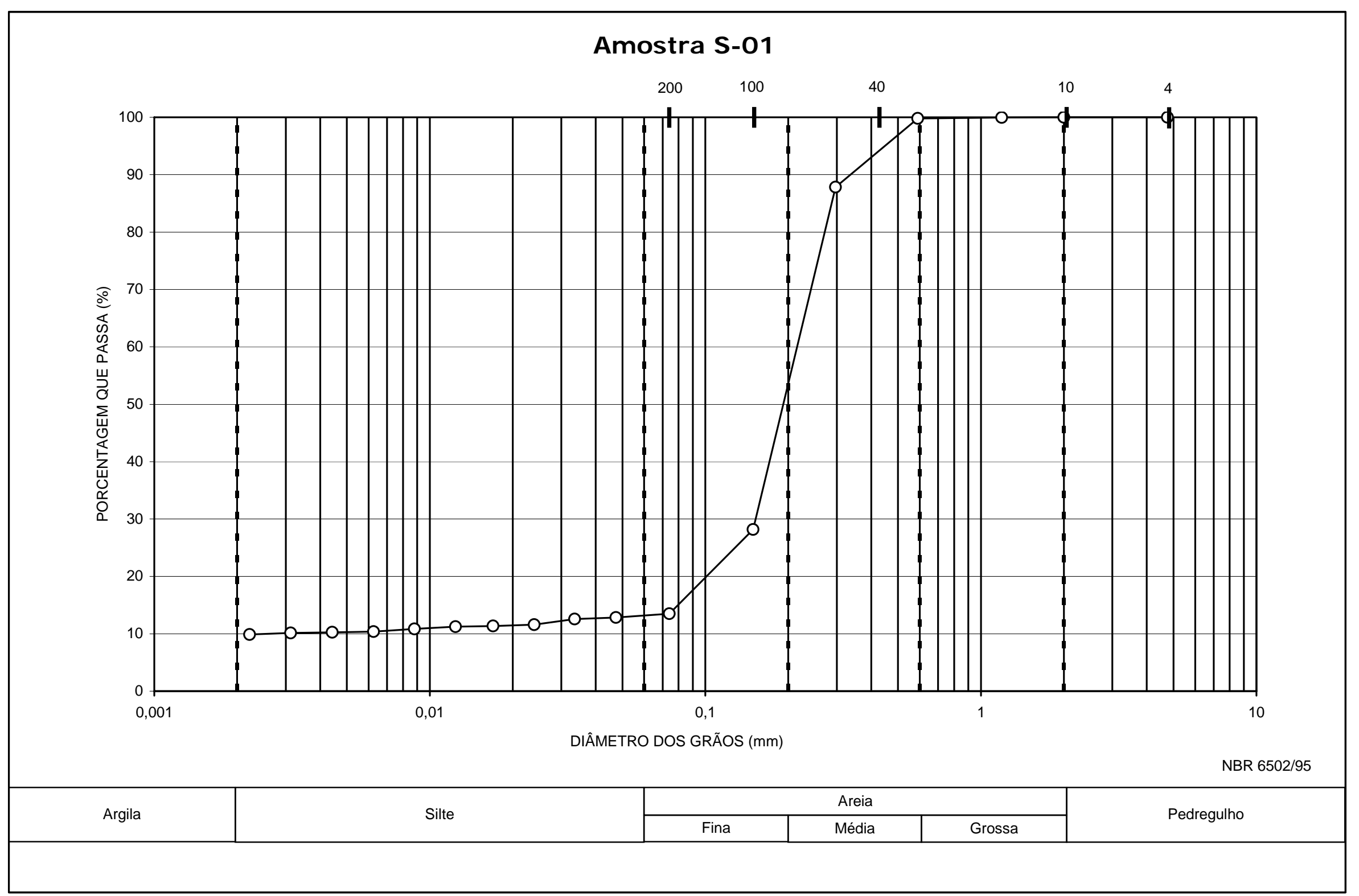




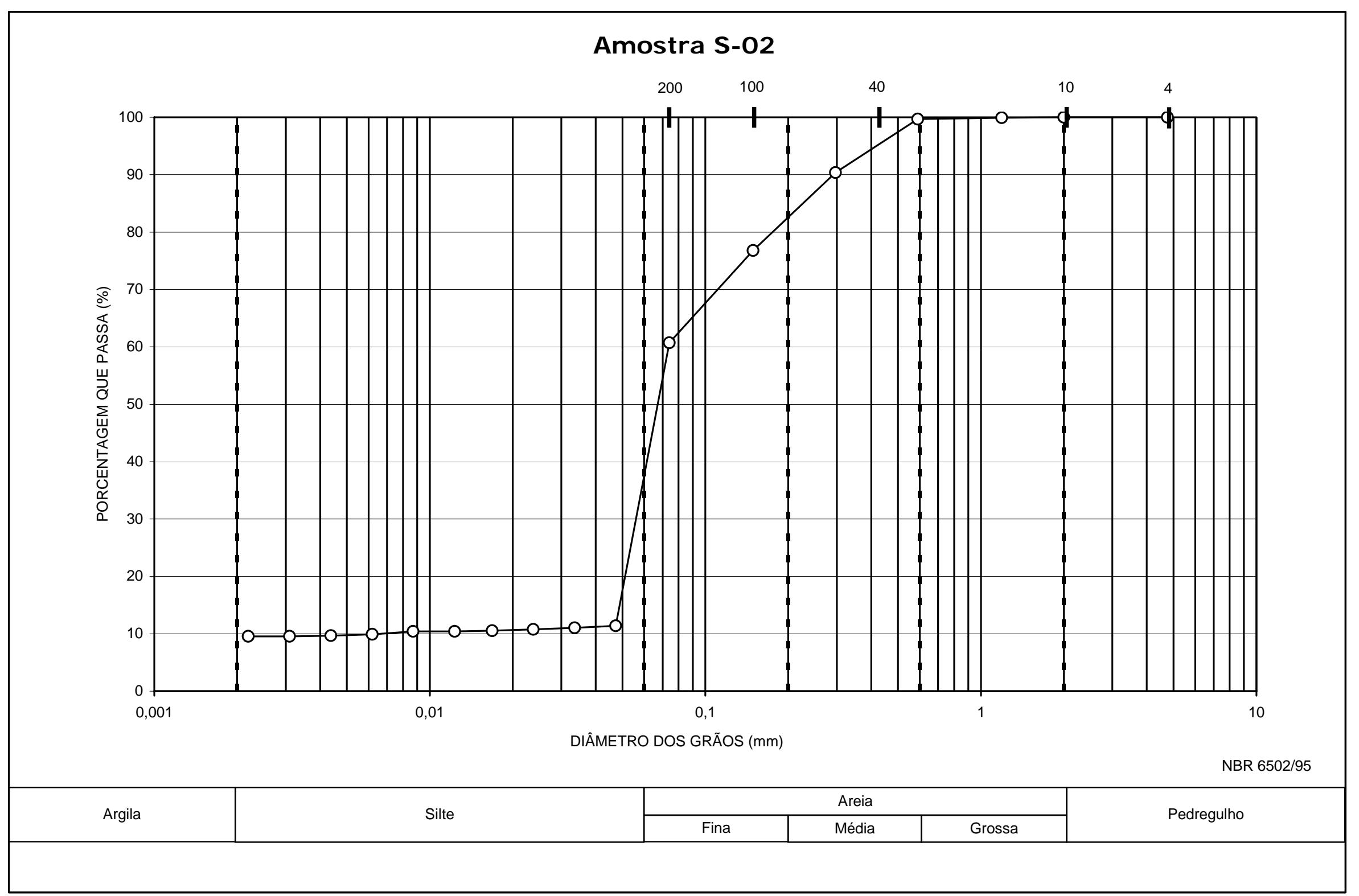




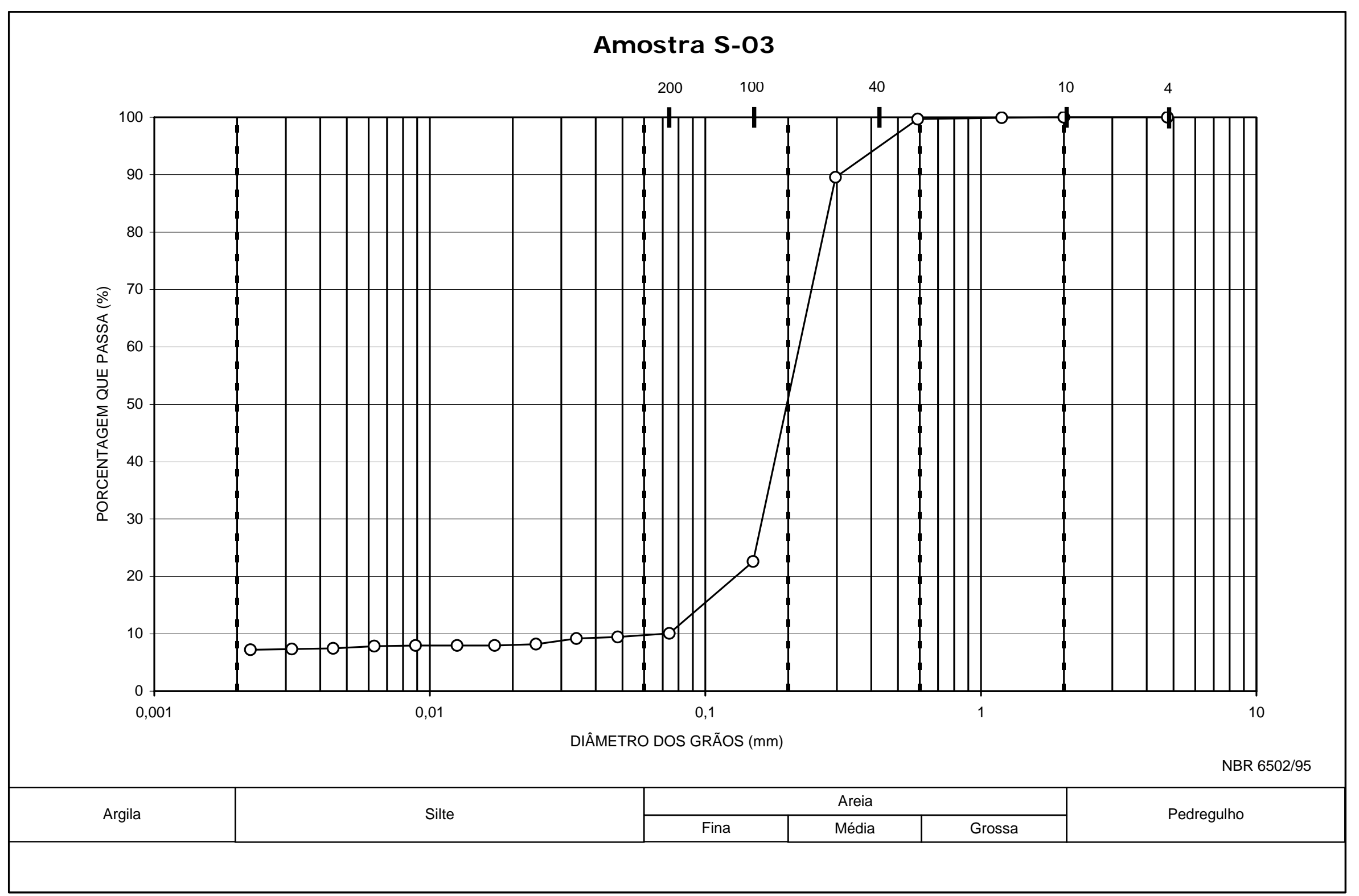




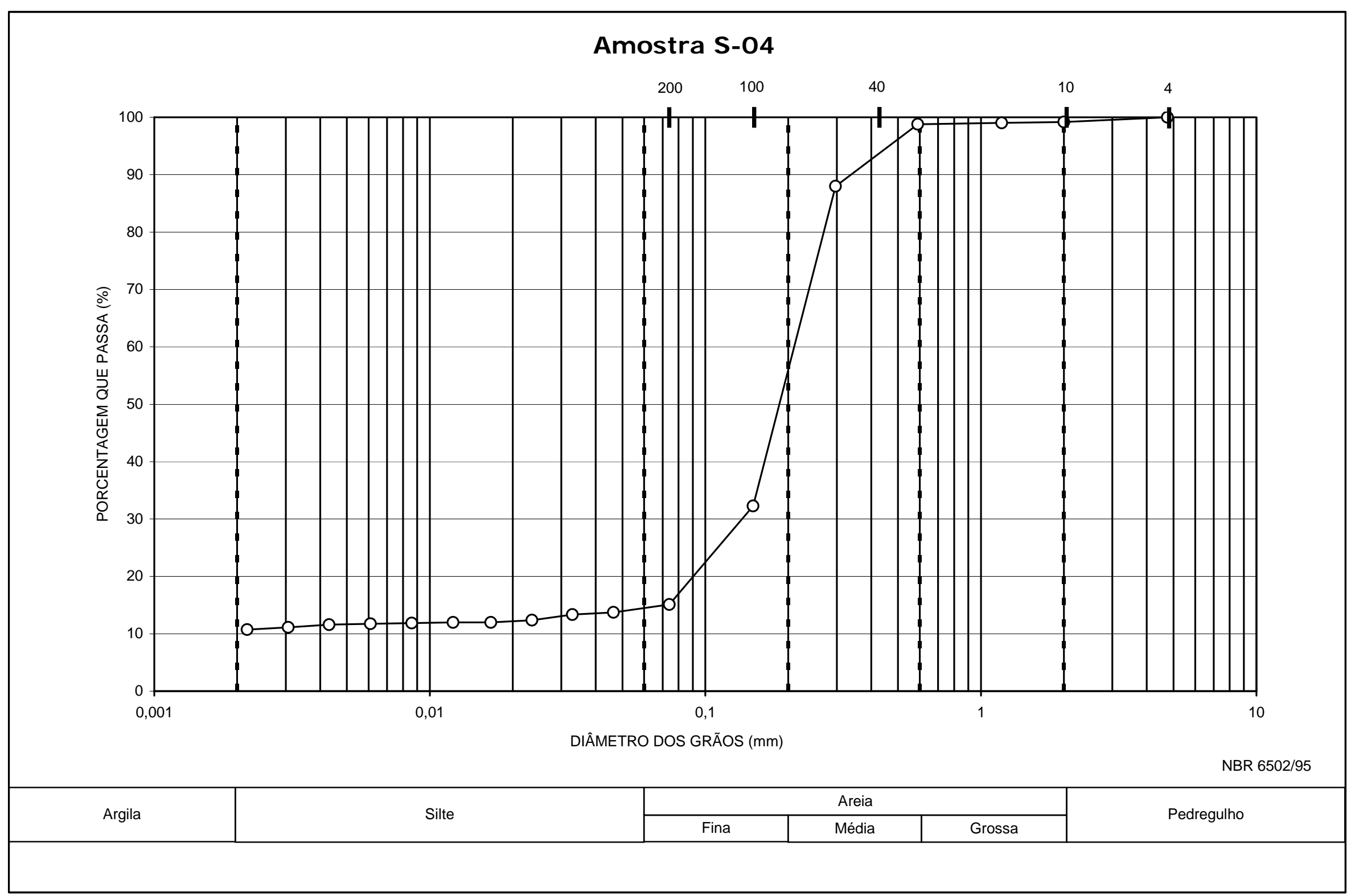




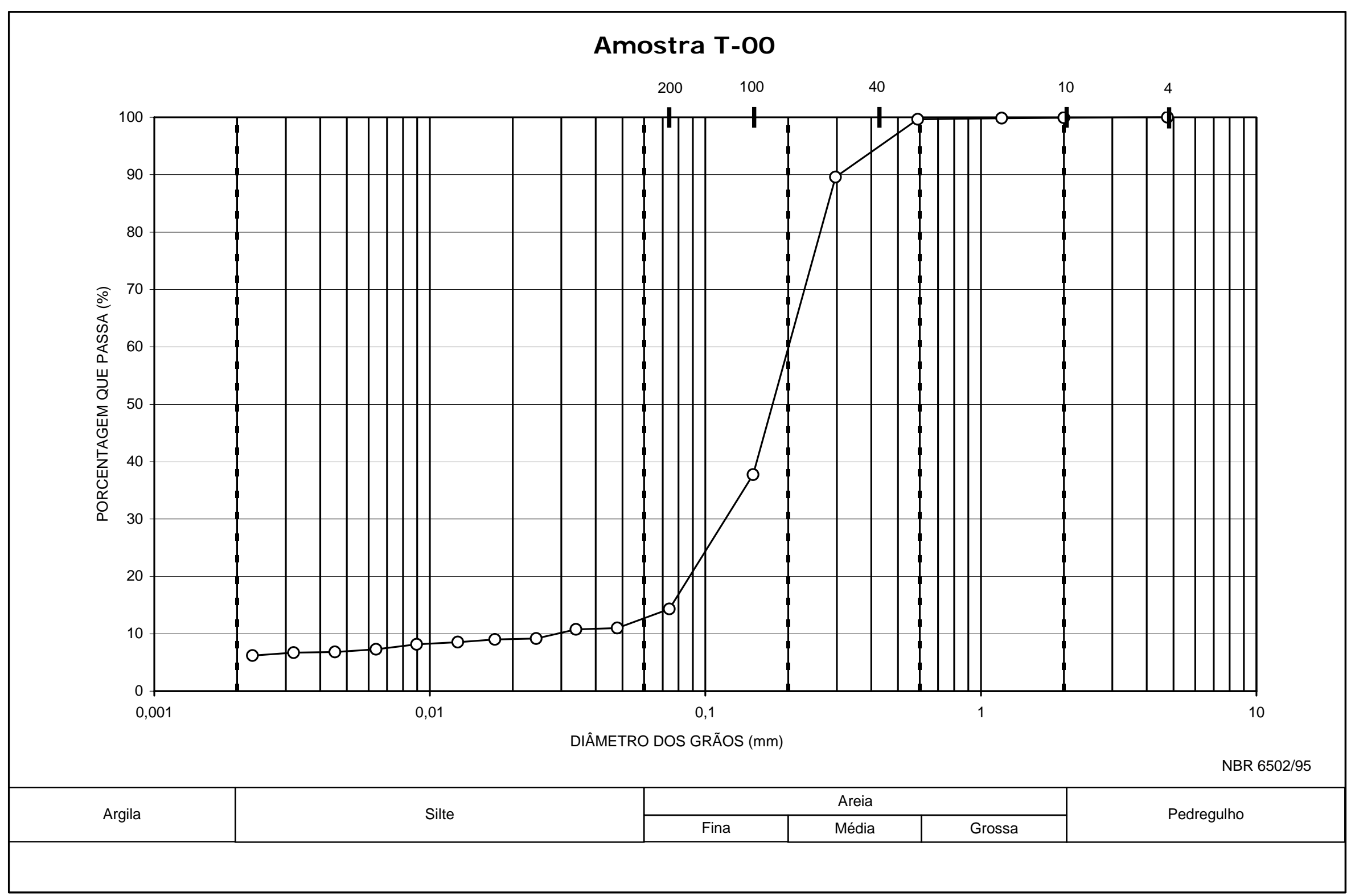




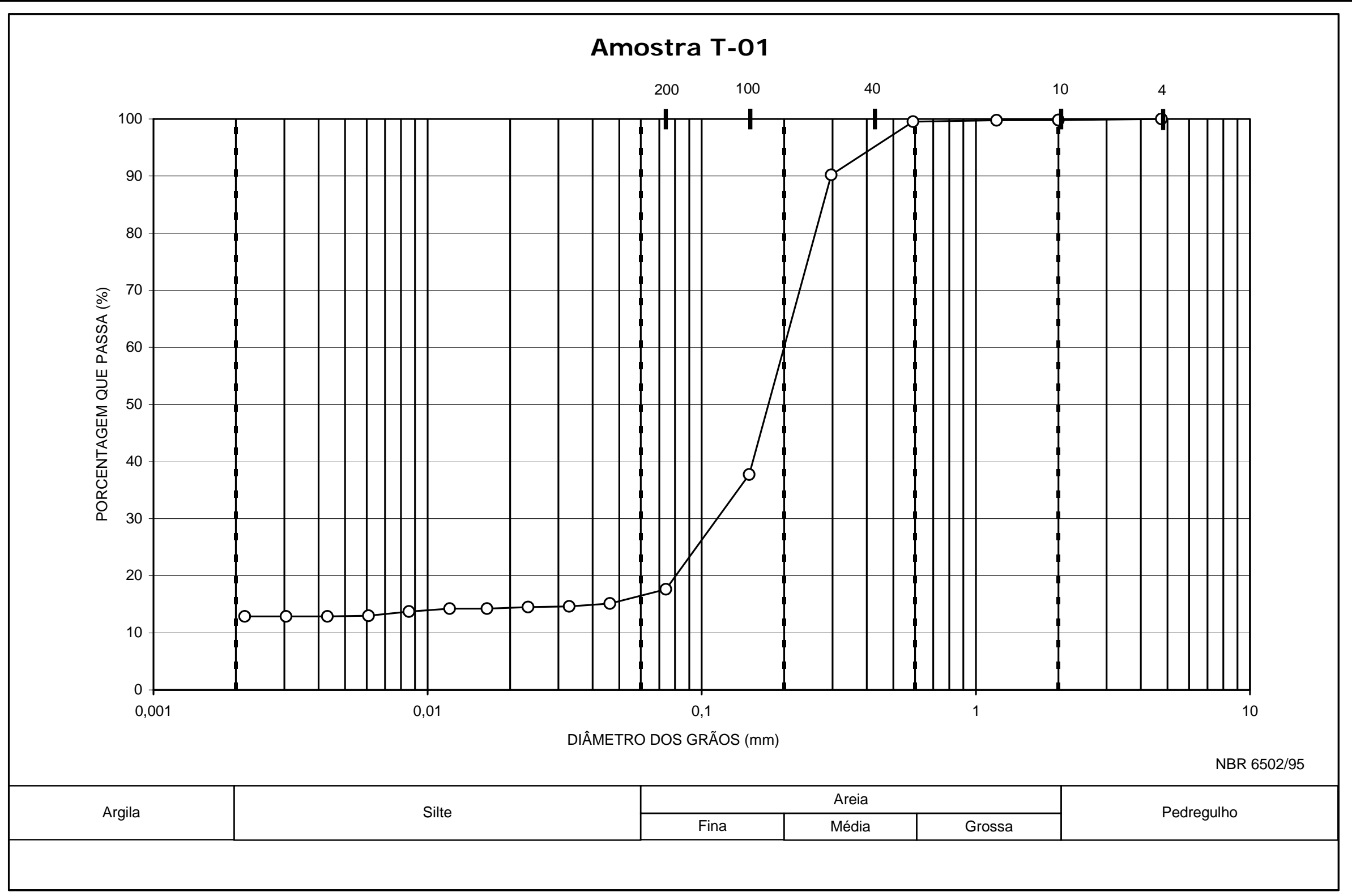




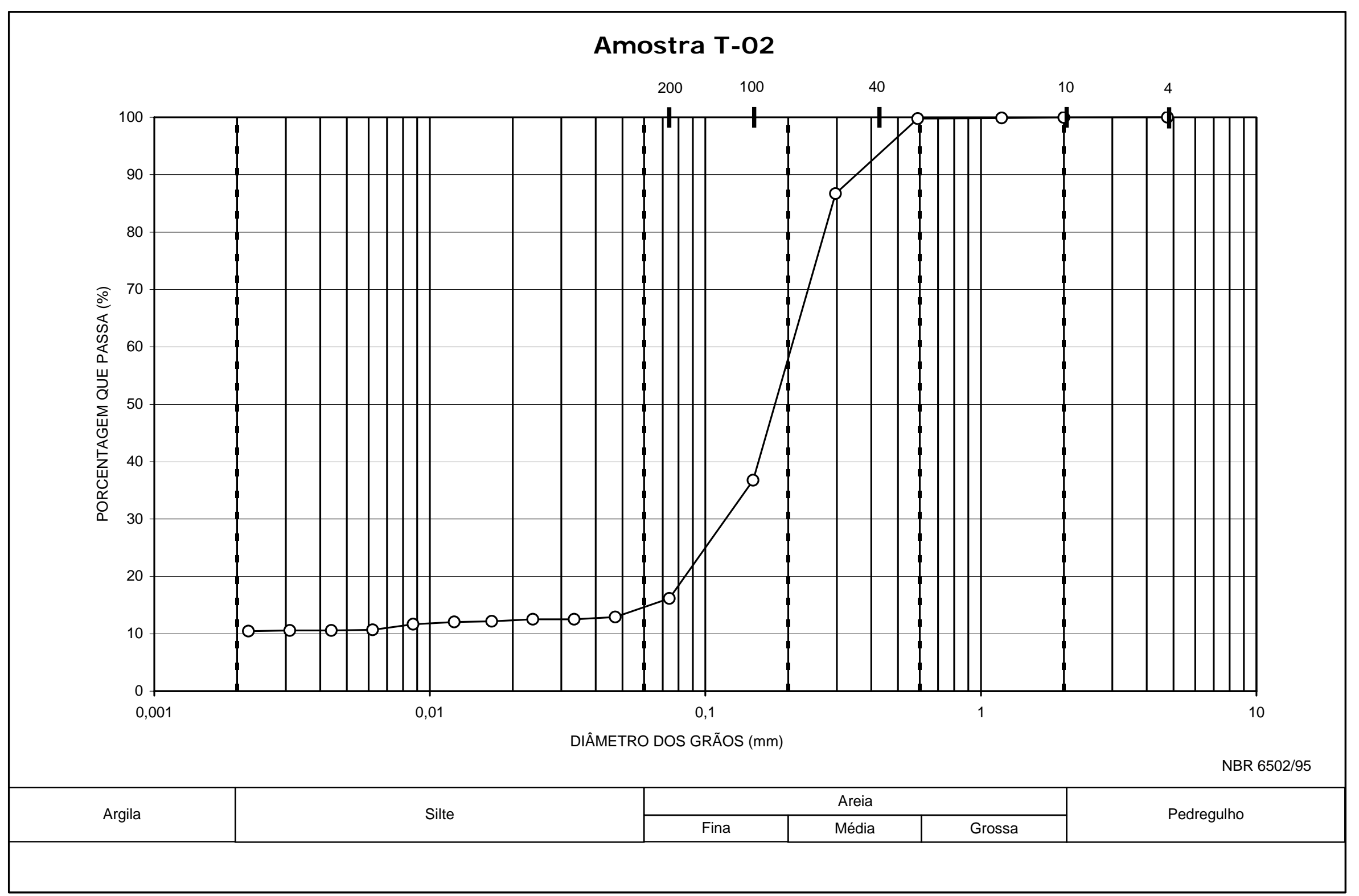




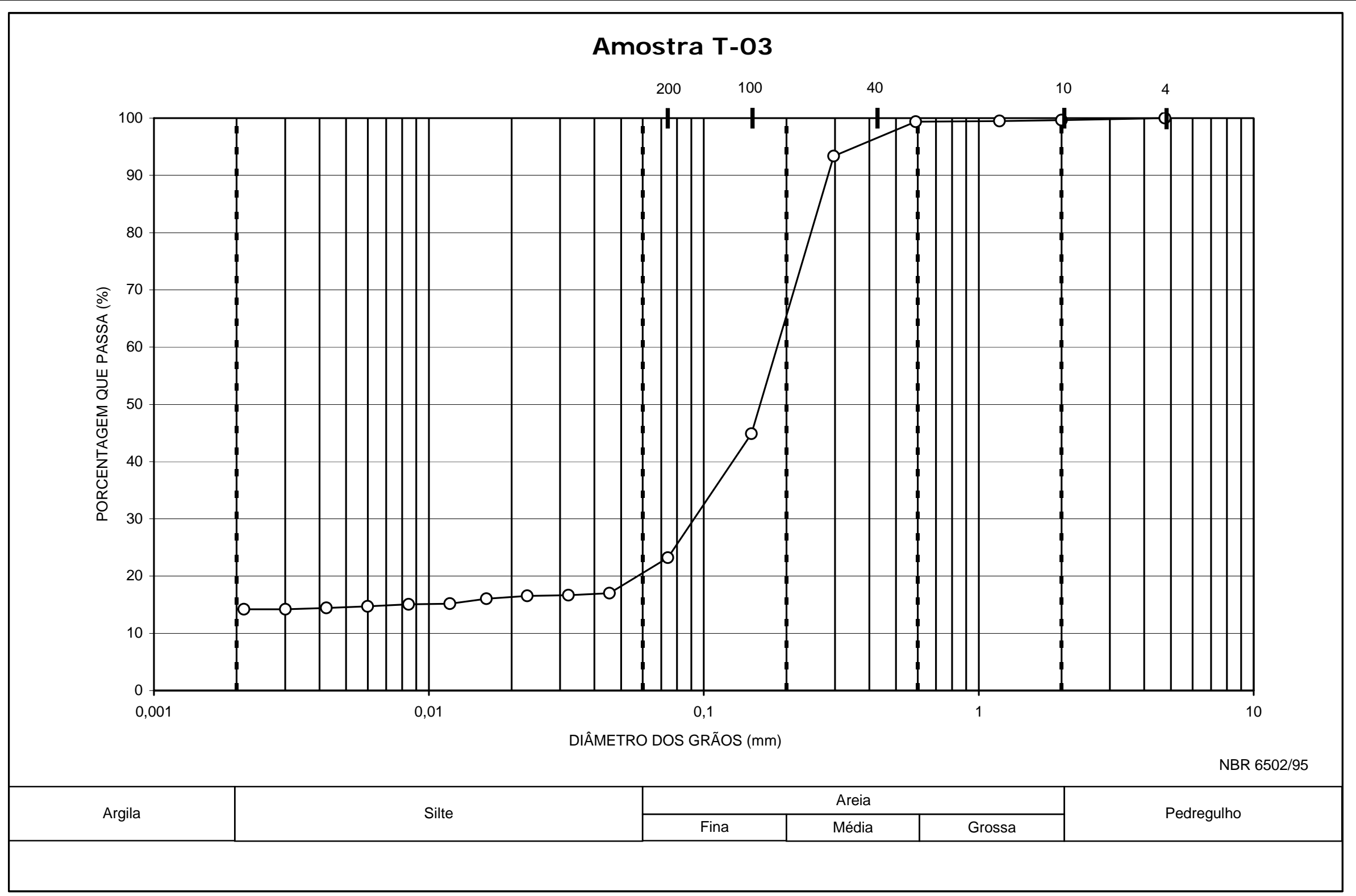




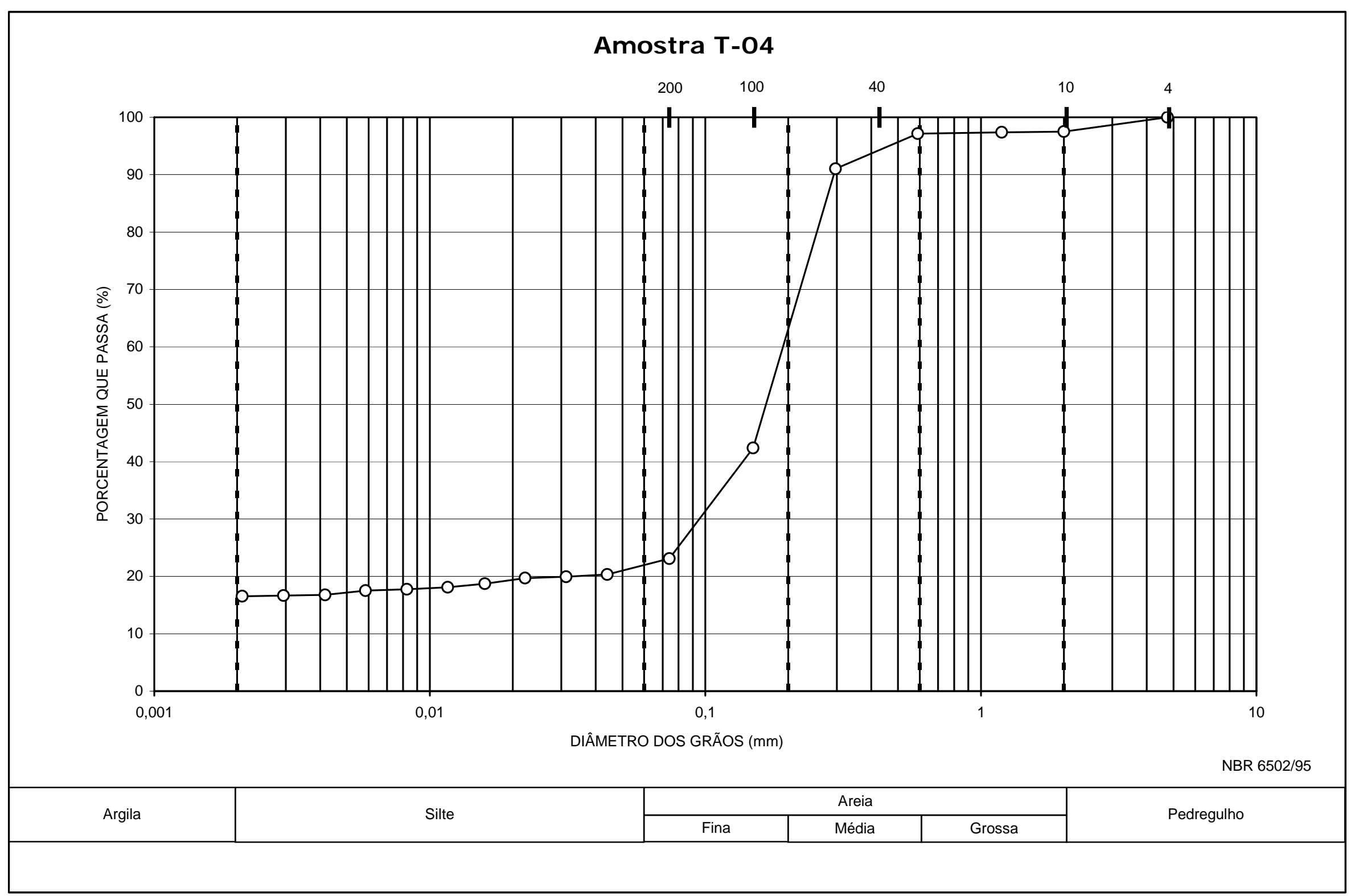




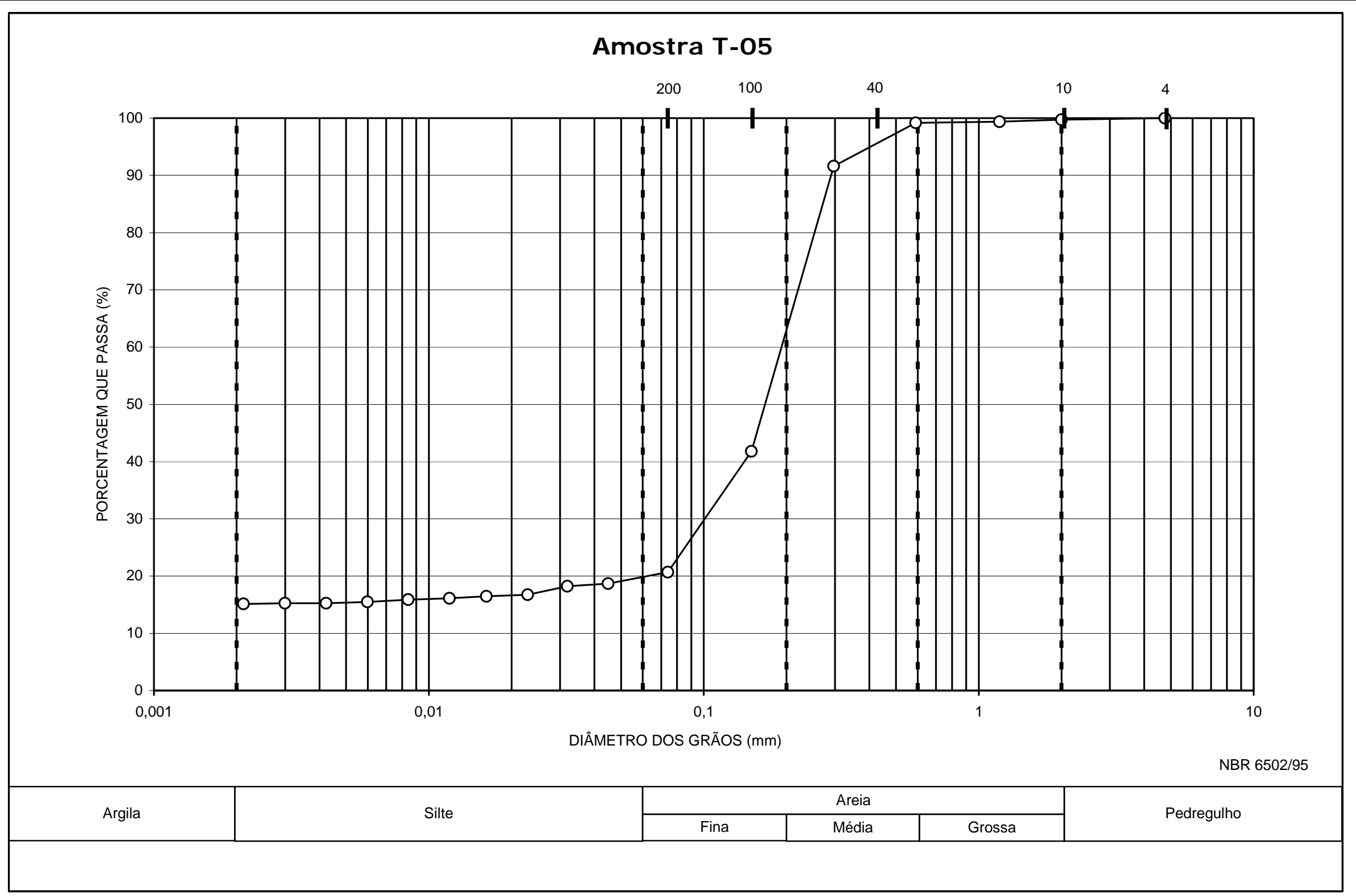




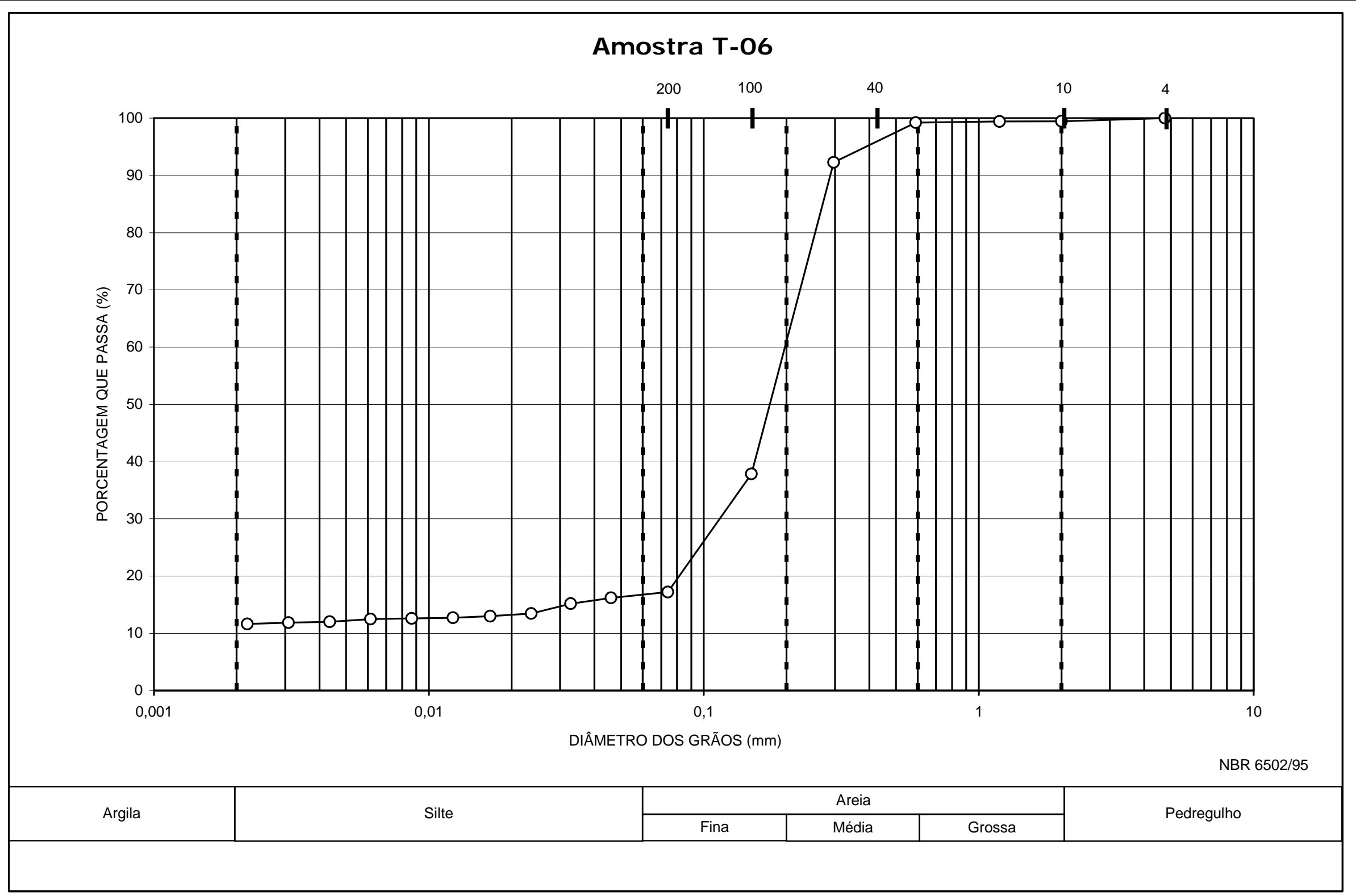




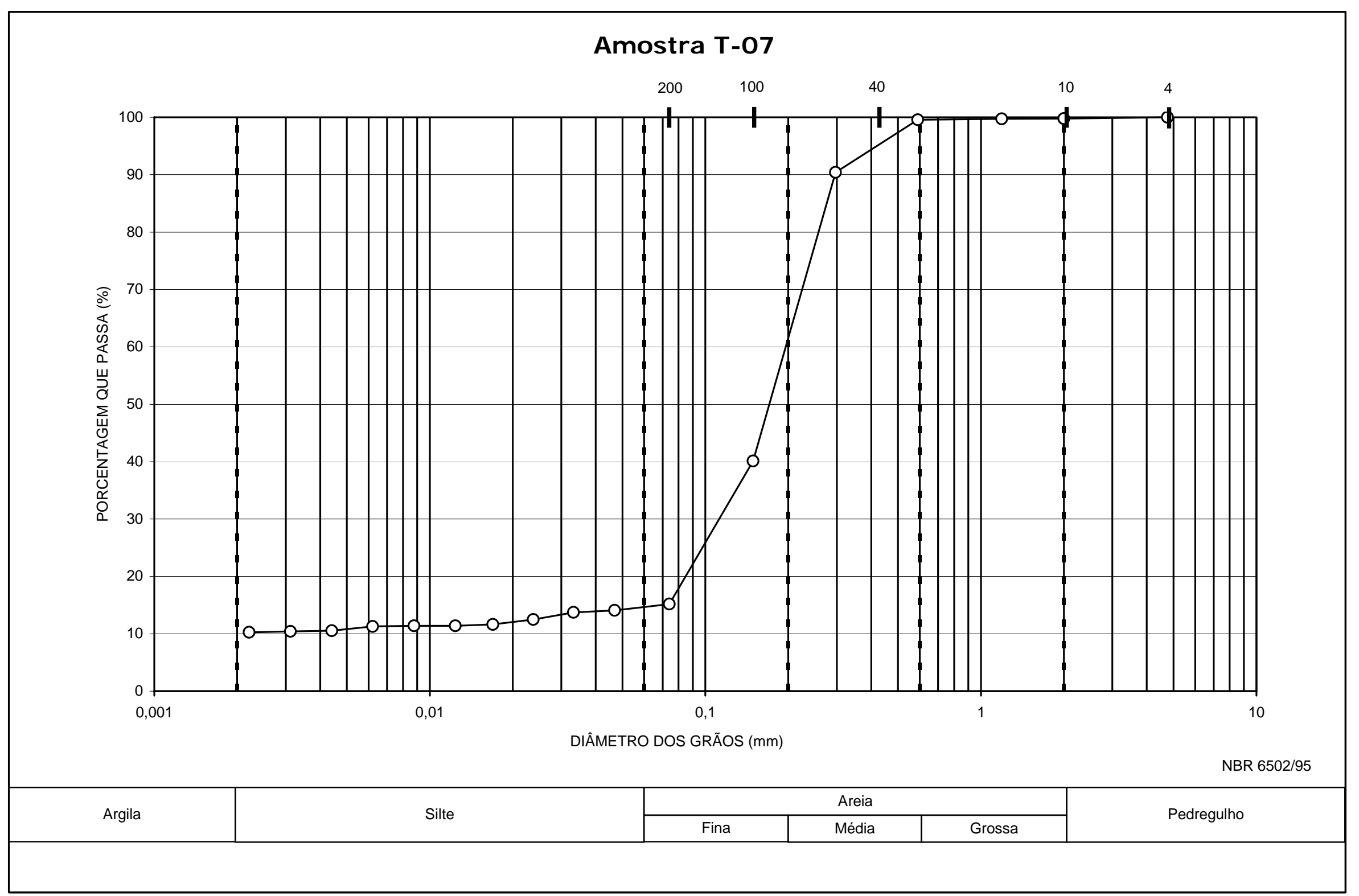




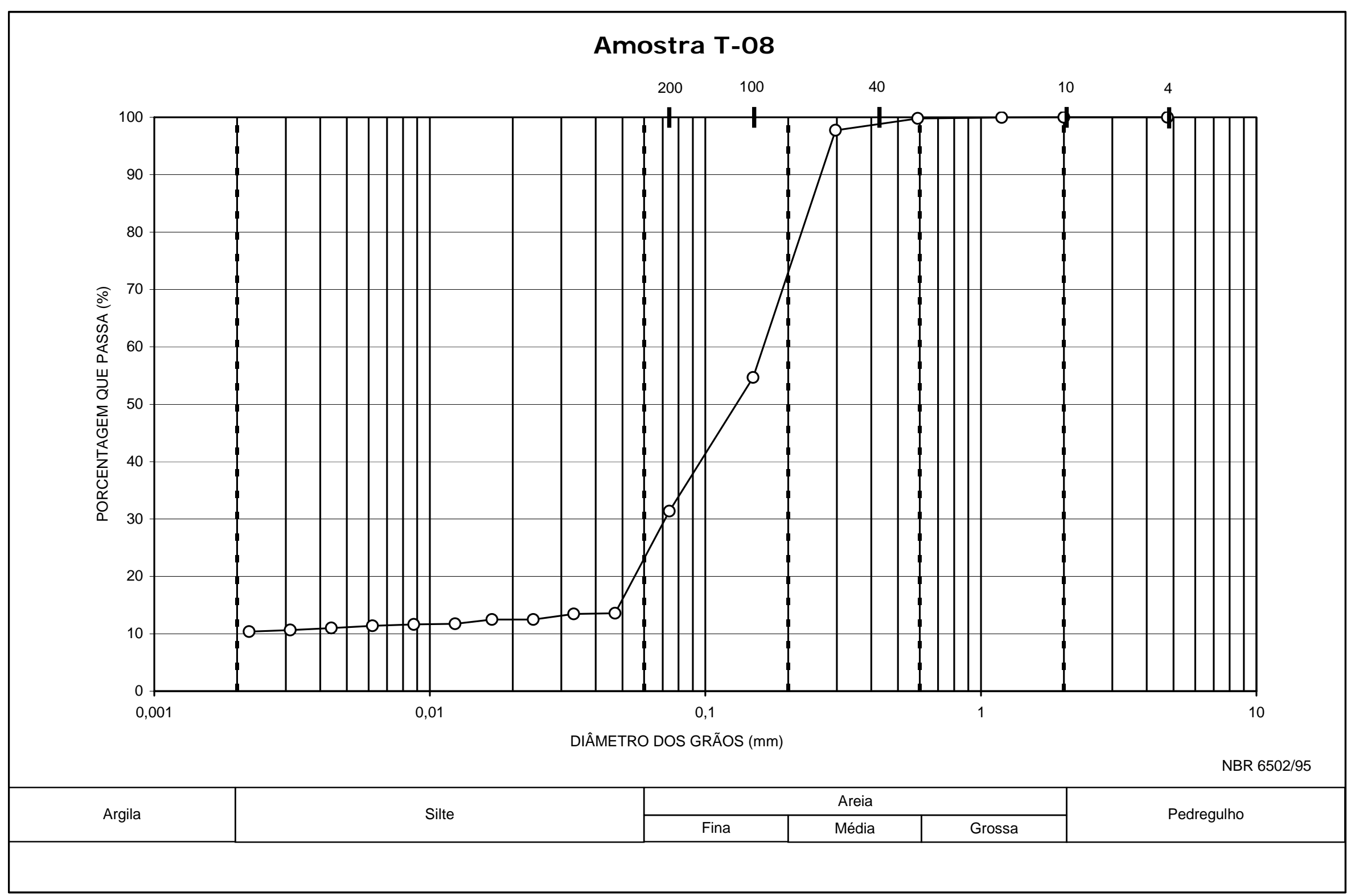




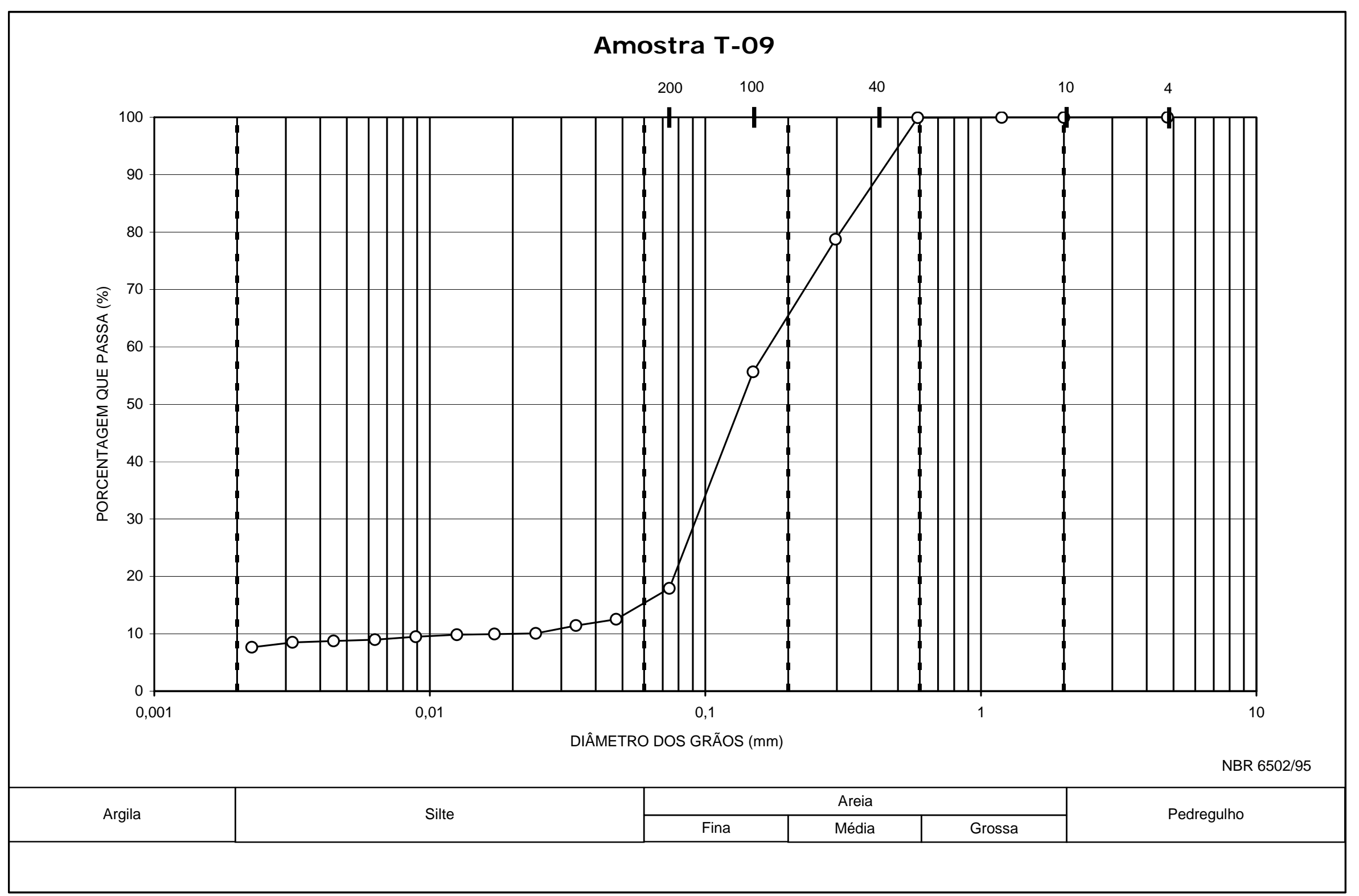




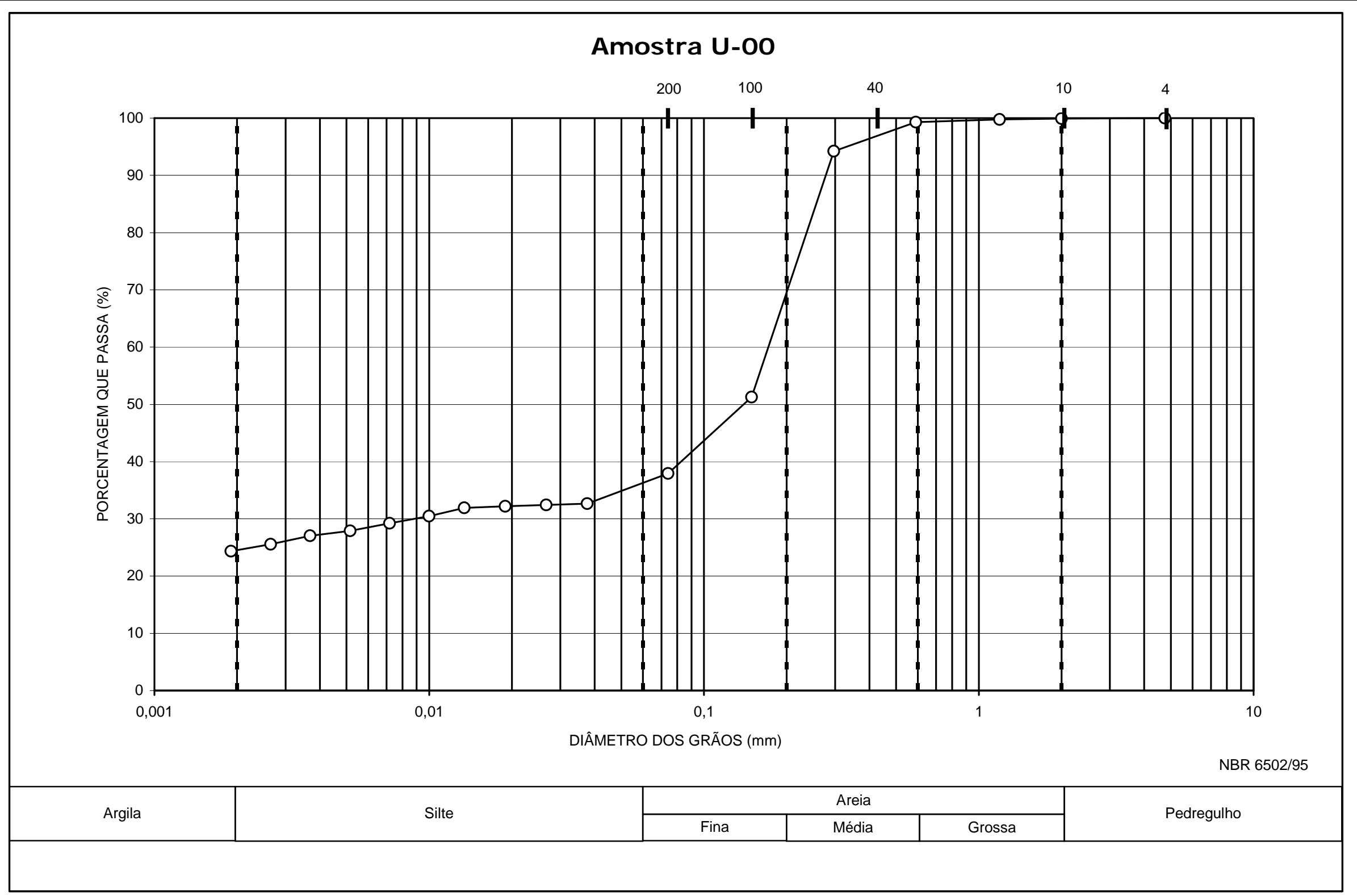




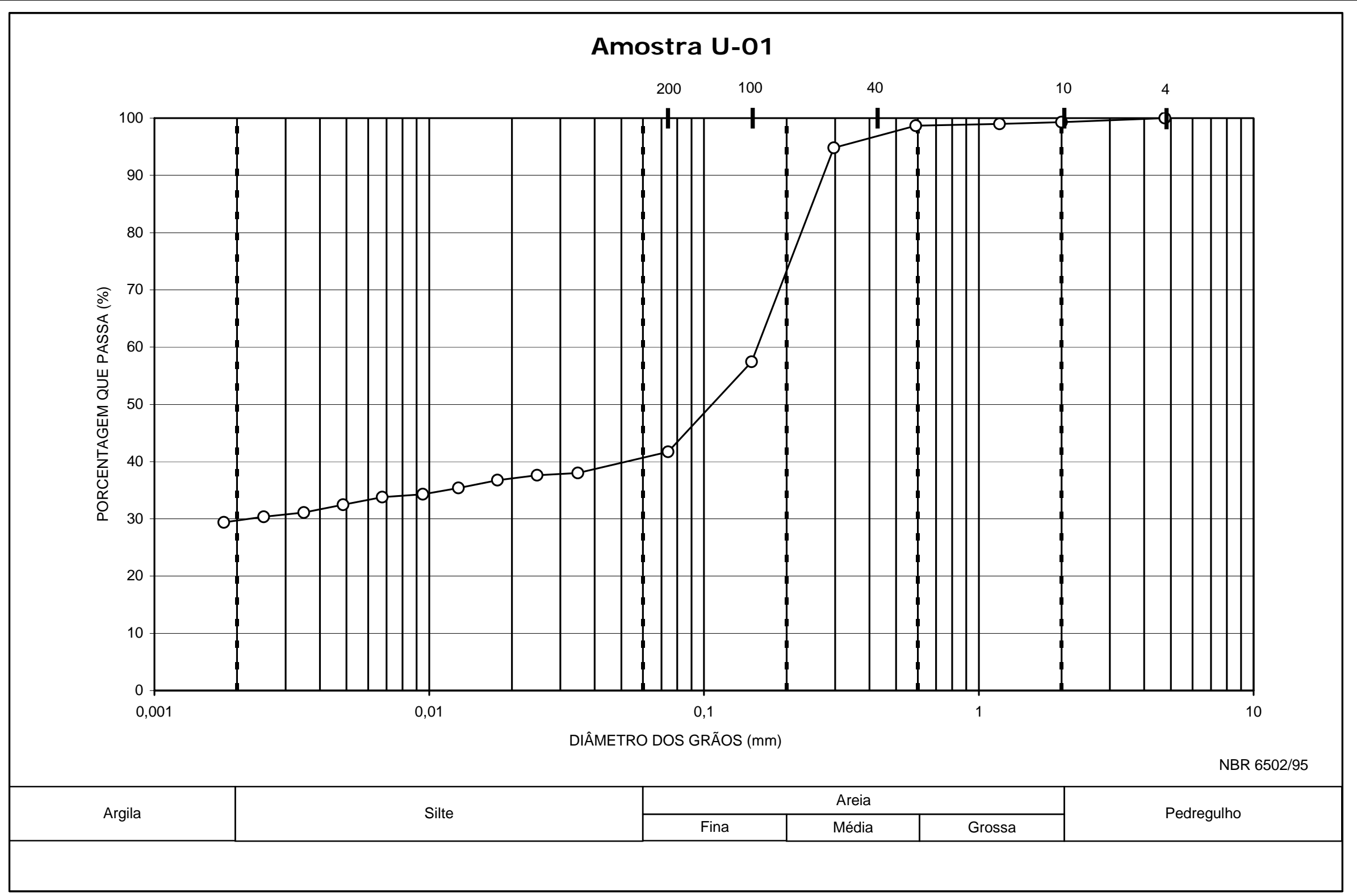




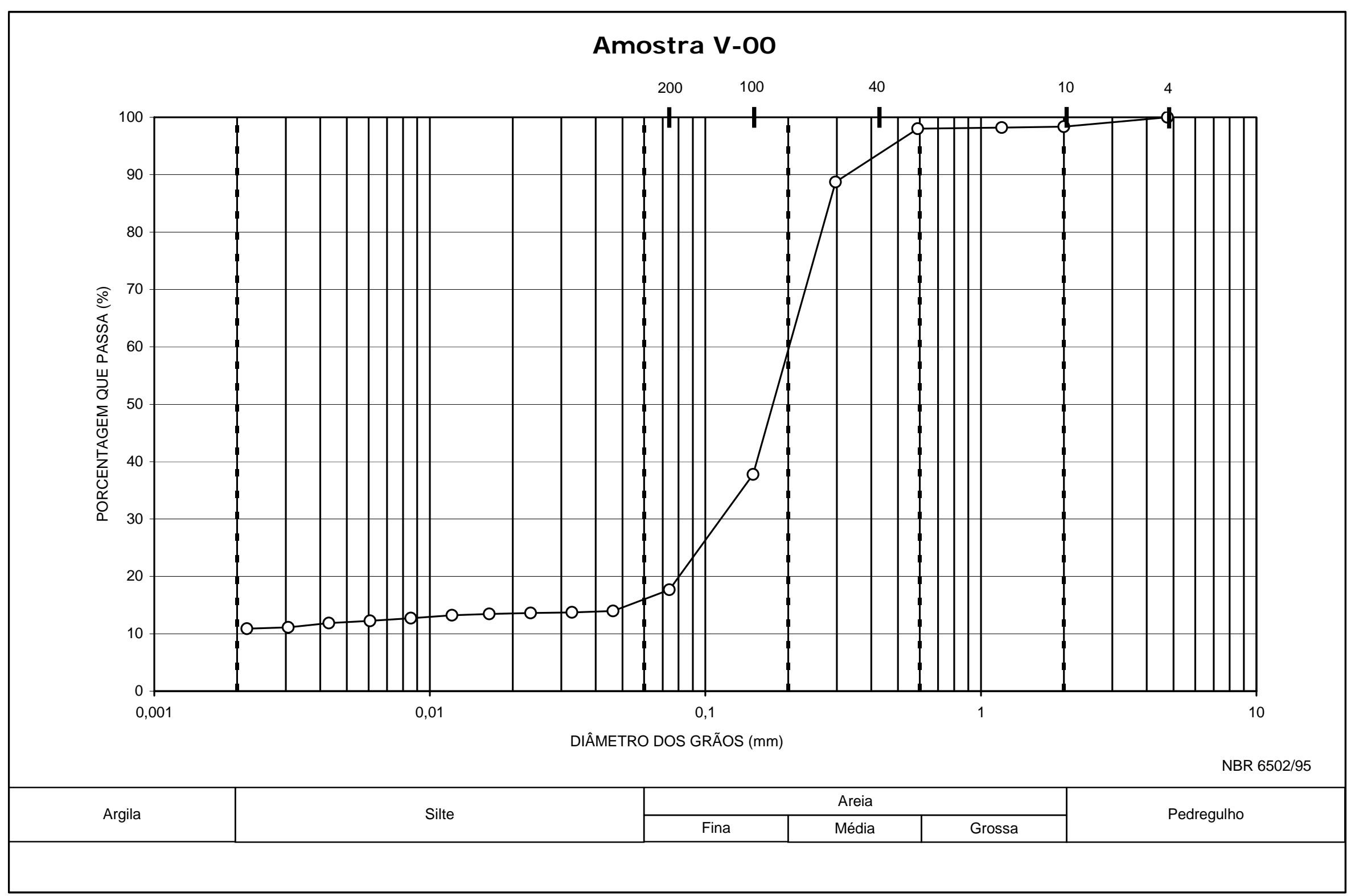




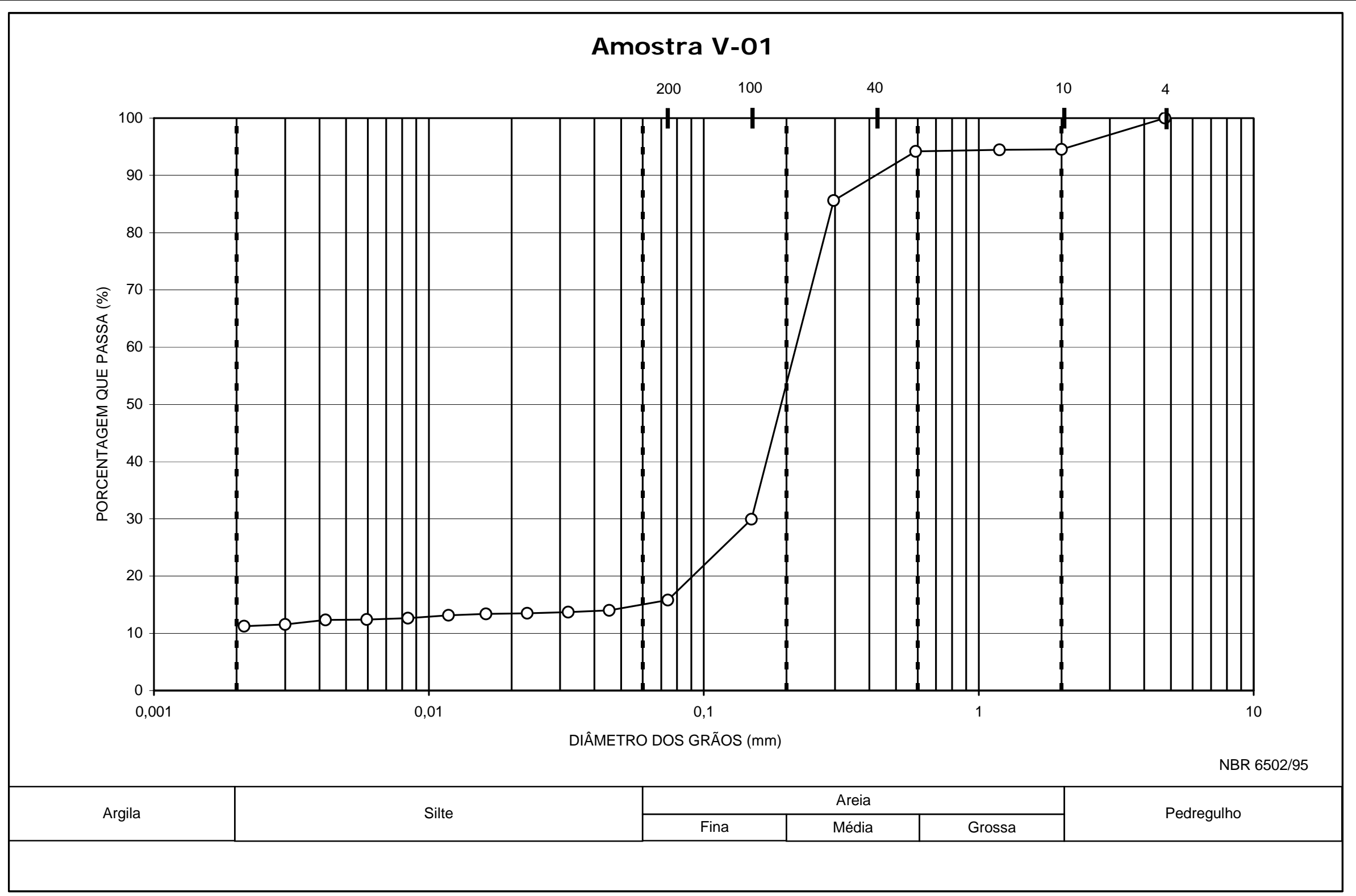

